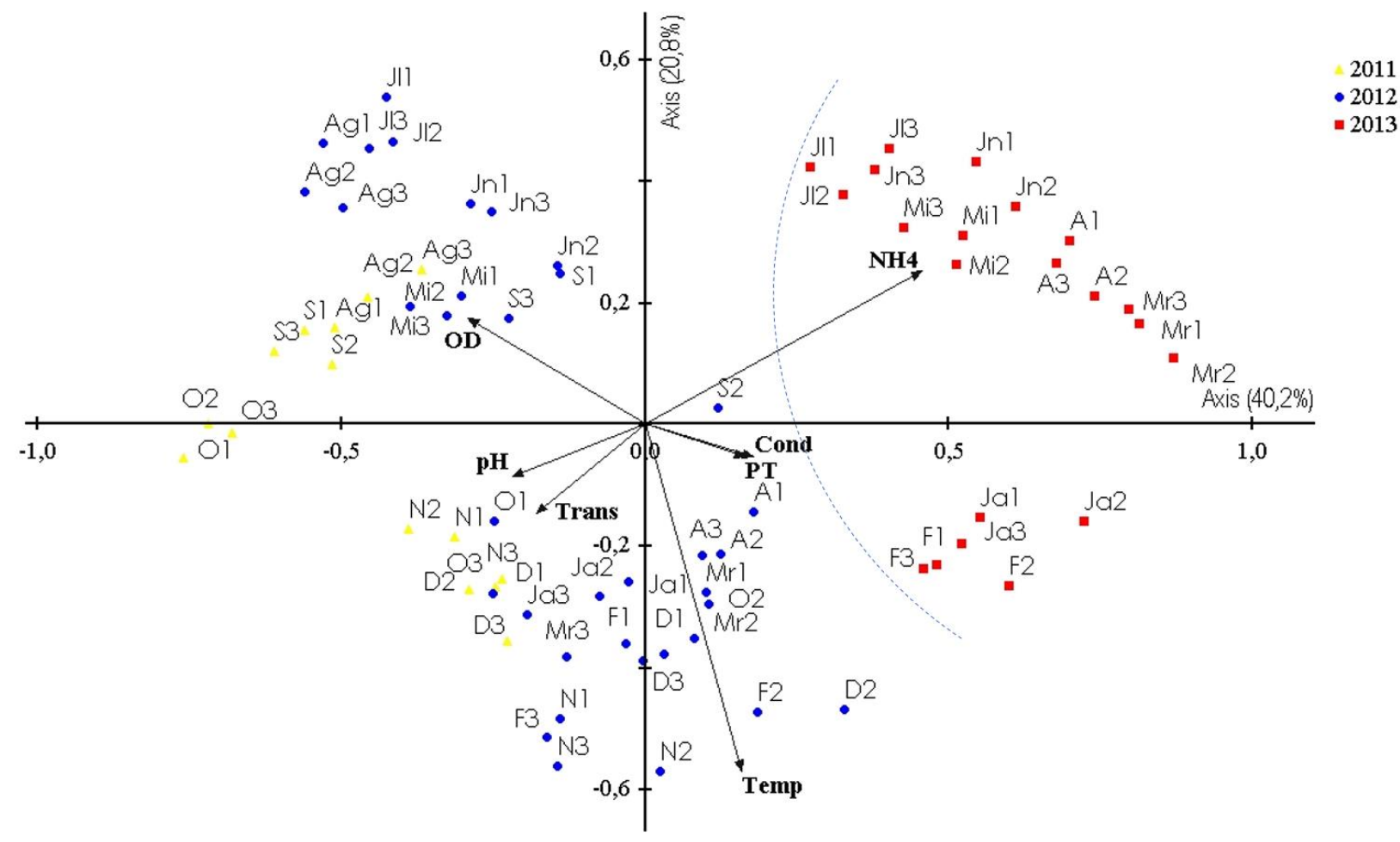




\section{EDITORIAL BOARD}

\section{Editors}

Getulio Teixeira Batista (Emeritus Editor) Universidade de Taubaté - UNITAU, BR

Nelson Wellausen Dias (Editor-in-Chief), Fundação Instituto Brasileiro de Geografia e Estatística - IBGE, BR

Ana Aparecida da Silva Almeida

Marcelo dos Santos Targa

Andrea Giuseppe Capodaglio

Arianna Callegari

Antonio Teixeira de Matos

Apostol Tiberiu

Claudia M. dos S. Cordovil

Dar Roberts

Giordano Urbini

Gustaf Olsson

Hélio Nobile Diniz

Ignacio Morell Evangelista

János Fehér

Julio Cesar Pascale Palhares

Luis Antonio Merino

Maria Cristina Collivignarelli

Massimo Raboni

Petr Hlavínek

Richarde Marques da Silva

Stefan Stanko

Teresa Maria Reyna

Yosio Edemir Shimabukuro

Zhongliang Liu Beijing

Text Editor

Reference Editor

Peer-Reviewing Process

System Analyst

Secretary and Communication

\section{Associate Editors}

Universidade de Taubaté (UNITAU), BR

Universidade de Taubaté (UNITAU), BR

\section{Editorial Commission}

University of Pavia, ITALY

Università degli Studi di Pavia, ITALY

Universidade Federal de Minas Gerais (UFMG), BR

University Politechnica of Bucharest, Romênia

Centro de estudos de Engenharia Rural (CEER), Lisboa, Portugal

University of California, Santa Barbara, United States

University of Insubria, Varese, Italy

Lund University, Lund, Sweden

Inst. Geológico, Sec. do Meio Amb. do Est. de SP (IG/SMA), BR

University Jaume I- Pesticides and Water Research Institute, Spain

Debrecen University, Hungary

Embrapa Pecuária Sudeste, CPPSE, São Carlos, SP, BR

Institute of Regional Medicine, National University of the Northeast, Corrientes, Argentina

University of Pavia, Depart. of Civil Engineering and Architecture, Italy

LIUC - University "Cattaneo", School of Industrial Engineering, Italy

Brno University of Technology República Tcheca

Universidade Federal da Paraíba (UFPB), BR

Slovak Technical University in Bratislava Slovak, Eslováquia

Universidad Nacional de Córdoba, Argentina

Instituto Nacional de Pesquisas Espaciais (INPE), BR

University of Technology, China

Theodore D`Alessio, FL, USA, Maria Cristina Bean, FL, USA

Liliane Castro, Bibliotecária - CRB/8-6748, Taubaté, BR

Marcelo Siqueira Targa, UNITAU, BR

Tiago dos Santos Agostinho, UNITAU, BR

Luciana Gomes de Oliveira, UNITAU, BR

\section{Library catalog entry by Liliane Castro CRB/8-6748}

Revista Ambiente \& Água - An Interdisciplinary Journal of Applied Science / Instituto de Pesquisas Ambientais em Bacias Hidrográficas. Taubaté. v. 14, n.4 (2006) - Taubaté: IPABHi, 2019.

Quadrimestral (2006 - 2013), Trimestral (2014 - 2016), Bimestral (2017), Publicação Contínua a partir de Janeiro de 2018.

Resumo em português e inglês.

ISSN 1980-993X

1. Ciências ambientais. 2. Recursos hídricos. I. Instituto de Pesquisas Ambientais em Bacias Hidrográficas.

CDD - 333.705

CDU - (03)556.18 


\section{TABLE OF CONTENTS}

\section{COVER:}

With the goal of assessing possible impacts of fish farming in great-volume cage systems on the water quality of a reservoir, the authors provided abiotic data from 72 samples obtained before and after farming site implementation. The figure shows the principal components analysis results for seven limnological variables. The highest dissolved oxygen (OD) concentrations were observed before the fish farm became operational. During the post-production period, the highest phosphorous $(\mathrm{PT})$ and ammonium $\left(\mathrm{NH}_{4}\right)$ concentrations were observed as well as high conductivity and turbidity values. Authors concluded that fish farming in cage systems located in Solteira Island Reservoir, Brazil, caused significant temporal and sudden spatial changes in water physical and chemical variables. Source: ROSINI, E. F. et al. Water quality in Ponte Pensa Aquaculture Park, Solteira Island Reservoir, SP, Brazil, where fish are cultivated under greatvolume cage system. Rev. Ambient. Água, Taubaté, vol. 14 n. 4, p. 1-14, 2019. doi:10.4136/ambi-agua.2382

\section{ARTICLES}

Evaluation of endoglucanase and $\beta$-glucosidase production by bacteria and yeasts isolated from a eucalyptus plantation in the cerrado of Minas Gerais

01 doi:10.4136/ambi-agua.2324

Farley Souza Ribeiro Menezes; Gizelly Gomes da Cruz; Matheus de Oliveira Lopes; David Lee Nelson; Tamira Quintiliana Gomes Martins; Marcelo Luiz de Laia

Genesis of sandstone-derived soils in the Cerrado of the Piauí State, Brazil

doi:10.4136/ambi-agua.2355

Diego Ferreira de Souza; Ronny Sobreira Barbosa; Yuri Jacques Agra Bezerra da Silva; Márcio Cleto Soares de Moura; Romário Porto de Oliveira; Vanessa Martins

Deforestation impact on discharge regime in the Doce River Basin

03 doi:10.4136/ambi-agua.2370

Barbara Ucelis Lyra; Daniel Rigo

Analysis of cloud condition on Sentinel-2 MSI and Landsat-8 OLI images of a public supply lake in Belém-Pará-Brazil

04 doi:10.4136/ambi-agua.2375

Vítor Abner Borges Dutra; Paulo Amador Tavares; Hebe Morganne Campos Ribeiro

Influence of organic mulching on drip irrigation management of cabbage cultivation

05 doi:10.4136/ambi-agua.2381

Andressa Scholz Berça; Thais Grandizoli Mendonça; Claudinei Fonseca Souza

Water quality in Ponte Pensa Aquaculture Park, Solteira Island Reservoir, SP, Brazil, where fish are cultivated under great-volume cage system

06

doi:10.4136/ambi-agua.2382

Edna Ferreira Rosini; Andréa Tucci; Clóvis Ferreira do Carmo; Helenice Pereira de Barros

Evaluation of the use of fertilizer obtained from pharmaceutical effluent

07

doi:10.4136/ambi-agua.2262

Carina Aline Prado; Mariana Paiva Batagini Giron; Fernanda Gonçalves Mendes;

Marco Aurélio Kondracki de Alcântara; Hélcio José Izário Filho

Changes in physicochemical and toxicological parameters of waters of Trincheira's River caused by road construction

Juan Camilo Pires Salcedo Restrepo; Danieli Iara Antonelo; Ticiane Sauer Pokrywiecki;

Ivane Benedetti Tonial; Fernando César Manosso; Igor Vivian de Almeida;

Veronica Elisa Pimenta Vicentini; Elisângela Düsman 
Autochthonous microalgae cultivation with anaerobic effluent: isolation of strains, survivorship, and characterization of the produced biomass

9 doi:10.4136/ambi-agua.2362

Helenice Silva de Jesus; Servio Tulio Alves Cassini; Marcos Vinicius Pereira; Aline Figueredo Dassoler; Ricardo Franci Gonçalves

Removal of organic matter from pre-treated domestic sewage in anaerobic biological reactor by a combined system of electrolytic and biological aerobic treatment

Ariela Araujo Fonseca; Yovanka Pérez Ginoris; Norma Mendes Pinheiro Gontijo;

Marco Antonio Almeida de Souza

Sensitivity of hydrological connectivity in a semiarid basin with a high-density reservoir network

11 doi:10.4136/ambi-agua.2367

Cristian Epifanio Toledo; Nayra Rodrigues Alcantara

Selection of variables in the definition of a water quality index for the Brazilian Federal District

12 doi:10.4136/ambi-agua.2385

Ana Luiza Litz Passos; Daphne Heloisa de Freitas Muniz; Leandro Pin Rangel;

Eduardo Cyrino Oliveira-Filho

Analysis of the effect of impermeability of urban soils on the infiltration of rainwater in the city of Recife, PE

Marco Aurelio Calixto Ribeiro de Holanda; Willames de Albuquerque Soares

Constructed wetlands as post treatment of a decanter digester followed by an anaerobic filter

14 doi:10.4136/ambi-agua.2335

Wilhan Douglas Reis; Aldecy de Almeida Santos; Eduarda da Conceição Oliveira; João Batista Ito

Post-treatment of landfill leachate using rice husk ash as adsorbent medium 


Ambiente \& Água - An Interdisciplinary Journal of Applied Science
ISSN 1980-993X - doi:10.4136/1980-993X
www.ambi-agua.net
E-mail: ambi.agua@gmail.com

\title{
Evaluation of endoglucanase and $\beta$-glucosidase production by bacteria and yeasts isolated from an eucalyptus plantation in the cerrado of Minas Gerais
}

\author{
ARTICLES doi:10.4136/ambi-agua.2324
}

Received: 29 Aug. 2018; Accepted: 29 Apr. 2019

\author{
Farley Souza Ribeiro Menezes1id; Gizelly Gomes da Cruz ${ }^{1}$ iD; \\ Matheus de Oliveira Lopes ${ }^{2}$; David Lee Nelson' ${ }^{1}$; \\ Tamira Quintiliana Gomes Martins ${ }^{2}$; ; Marcelo Luiz de Laia ${ }^{2 *}$
}

\begin{abstract}
${ }^{1}$ Universidade Federal dos Vales do Jequitinhonha e Mucuri (UFVJM), Diamantina, MG, Brasil Instituto de Ciência, Engenharia e Tecnologia (ICET). E-mail: farley29menezes@ yahoo.com.br, gizelly.gc@gmail.com, dleenelson@gmail.com

${ }^{2}$ Universidade Federal dos Vales do Jequitinhonha e Mucuri (UFVJM), Diamantina, MG, Brasil

Departamento de Engenharia Florestal. E-mail: matheuoliveira@gmail.com, tamiragomes@yahoo.com.br, marcelolaia@gmail.com

"Corresponding author
\end{abstract}

\begin{abstract}
The current global environmental and economic scenario is intrinsically related to the increase in fossil fuel consumption caused by technological development and world population growth. Thus, it is necessary to search for renewable sources of biofuel in an attempt to mitigate the effects of fossil fuels on the environment and the lack of these non-renewable fuels. The use of lignocellulosic biomass, an abundant and renewable resource in Brazilian regions, has contributed successfully to new research and technologies for second-generation ethanol production. The conversion of lignocellulosic biomass into fermentable sugars requires the use of cellulolytic enzymes produced by microorganisms found in the microbiota. This work evaluated the production of endoglucanase and $\beta$-glucosidase in a liquid medium containing carboxymethylcellulose by five microorganisms (bacteria and yeasts) from the bank of 348 isolates from eucalyptus soils in the Cerrado Mineiro. Microorganisms with the following enzymatic activity indexes were selected: IM1-74 (22), IM25-9 (5.33), IM32-90 (7.33), IM1-5 (10.33) and IM32-91 (5.44). The microorganisms with the highest enzymatic activity in the liquid medium were IM32-90 (endoglucanase $\left.=0.214 \mathrm{U} \mathrm{mL}^{-1}\right)$ and IM32-91 $(\beta$-glucosidase $=$ $\left.0.067 \mathrm{U} \mathrm{mL}^{-1}\right)$.
\end{abstract}

Keywords: cellulase, enzymes, renewable sources.

\section{Avaliação da produção de endoglucanase e $\beta$-glicosidase por bactérias e leveduras isoladas de plantações de eucalipto no cerrado de Minas Gerais}

\section{RESUMO}

O atual cenário ambiental e econômico global tem uma relação intrínseca com o aumento do consumo de combustíveis fósseis causados pelo desenvolvimento de tecnologias e pelo crescimento da população mundial. Assim, é necessário procurar fontes renováveis de 
biocombustíveis na tentativa de mitigar os efeitos dos combustíveis fósseis no meio ambiente e a falta desses combustíveis não renováveis. O uso de biomassa lignocelulósica, um recurso abundante e renovável nas regiões brasileiras, contribuiu com sucesso para novas pesquisas e tecnologias para a produção de etanol de segunda geração. A conversão da biomassa lignocelulósica em açúcares fermentáveis requer o uso de enzimas celulolíticas produzidas por micro-organismos encontrados na microbiota. Este trabalho avaliou a produção de endoglucanase e $\beta$-glicosidase em meio líquido contendo carboximetilcelulose por cinco microorganismos bactérias e leveduras) do banco de 348 isolados de solos de eucalipto no Cerrado Mineiro. Foram selecionados micro-organismos com os seguintes índices de atividade enzimática: IM1-74 (22), IM25-9 (5.33), IM32-90 (7.33), IM1-5 (10.33) e IM32-91 (5.44). Os micro-organismos com maior atividade enzimática em meio líquido foram IM32-90 (endoglucanase $\left.=0,214 \mathrm{U} \mathrm{mL}^{-1}\right)$ e IM32-91 $\left(\beta\right.$-glicosidase $\left.=0,067 \mathrm{U} \mathrm{mL}^{-1}\right)$.

Palavras-chave: celulase, enzimas, fontes renováveis.

\section{INTRODUCTION}

Global dependence on fossil fuels has caused unfavorable effects such as declining crude oil reserves, declining air quality and rising global temperatures. To promote sustainability and independence from fossil fuels, bioethanol is now considered to be a good substitute for a fossil fuel mixture or gasoline (Aditiya et al., 2016; Toogood and Scrutton, 2018).

Lignocellulosic biomass represents a promising source of renewable energy, and can be used for the production of second-generation bioethanol (Squinca et al., 2018). Currently, most of the lignocellulosic ethanol is produced by hydrolysis and fermentation. The enzymatic saccharification of plant biomass is the most efficient method for the breakdown of lignocellulose to sugars, although the cost of this operation is still one of the main bottlenecks in the commercialization of second-generation alcohol and has been reported as the most expensive point in the entire chain of bioethanol production, accounting for up to $40 \%$ of the total cost (Choudhary et al., 2017; Cerda et al., 2017). Decreasing the cost of cellulolytic enzymes remains one of the main goals of bioethanol research, as it can reduce the cost of these enzymes by up to $20 \%$ (Dodda et al., 2018).

Cellulolytic enzymes include endo- and exoglucanases and beta-glucosidases that act synergistically and are necessary for the efficient hydrolysis of cellulose to soluble oligosaccharides (Lucarini et al., 2017). The endoglucanases initiate hydrolysis by slicing the cellulose structure, uncovering reducing and non-reducing ends, whereas cellobiohydrolases (exoglucanases) act upon both ends to release cello-oligosaccharides and cellobiose units. Subsequently, $\beta$-glucosidases chop cellobiose to release glucose molecules. Further, during the hydrolysis reaction, the endoglucanases act on the amorphous region, which is the more soluble portion of the cellulose structure; meanwhile, cellobiohydrolases cleave $\beta$-1,4-glycosidic bonds from the chain ends (Srivastava et al., 2018).

Cellulases have various kinds of industrial applications, including pulp and paper, laundry, food, animal feed, brewery and wine, textile, bioenergy industry (Idris et al., 2017). Significant research has been developed focusing on the isolation, identification and optimization of these enzymes, thus leading to the marketing of cellulases. Commercially available cellulases are a formulation of endoglucanases, exoglucanases, and $\beta$-glucosidases (Obeng et al.; 2017).

The enzymatic process is pollution-free, economical and cost-effective ( $\mathrm{Li}$ et al., 2012). This gives a new horizon to finding cost-effective cellulose-producing microorganisms. Microorganisms such as aerobic bacteria, fungi, yeasts and actinomycetes produce cellulases that degrade cellulose by hydrolysis of $\beta$-1,4-glycosidic bonds of cellulose (Behera et al., 2017).

The objective of this study was to evaluate the production of endoglucanase and $\beta$ -

Rev. Ambient. Água vol. 14 n. 4, e2324 - Taubaté 2019 
glucosidase by five microorganisms (bacteria and yeasts) isolated from the soil of a eucalyptus plantation in the cerrado region of the state of Minas Gerais, Brazil, with different periods of planting.

\section{MATERIALS AND METHODS}

For the evaluation of the production of endoglucanase and $\beta$-glucosidase, the 1-74, 25-9, 32-90, 1-5 and 32-91 microorganisms from the microorganisms bank of the Laboratory of Biotechnology and Genetics of the Department of Forest Engineering of the Federal University of the Jequitinhonha and Mucuri Valleys, Diamantina, Minas Gerais, Brazil, with previously calculated enzyme activity indices (EAI): EAI1-75 $=22$, EAI25-9 $=5.33$, EAI32-90 $=7.33$, EAI1-5 = 10.33 and EAI32-91 = 5.44 were employed.

\subsection{Culture medium and inoculum}

To prepare the inoculants, the microorganisms assigned as described above were inoculated on a Petri plate with culture medium containing carboxymethylcellulose (CMC) as the main carbon source, according to the composition described in Table 1, and incubated in BOD (SL 200/334 SOLAB®) at $28^{\circ} \mathrm{C}$ for 96 hours.

Table 1. Composition of the culture medium used for initiation of inoculum growth.

\begin{tabular}{lc}
\hline Components & Amount (g) \\
\hline MgSO$_{4} \cdot \mathbf{7 H}_{2} \mathrm{O}$ & 0.2 \\
$\mathrm{KH}_{2} \mathrm{PO}_{4}$ & 0.4 \\
$\mathrm{~K}_{2} \mathrm{HPO}_{4}$ & 0.1 \\
$\mathrm{NaCl}$ & 0.1 \\
Yeast extract & 0.4 \\
$\mathrm{CMC}$ & 10 \\
Agar & 15 \\
Distilled water & $1000 \mathrm{~mL}$ \\
\hline
\end{tabular}

The culture medium was prepared from the mixture of the components described in Table 1. The $\mathrm{pH}$ was adjusted to 6.0 , followed by sterilization in an autoclave at $121^{\circ} \mathrm{C}$ for $15 \mathrm{~min}$.

After growth was verified, the microorganism was scraped with the aid of a platinum handle and inoculated in $12 \mathrm{~mL}$ of culture medium with a composition similar to that mentioned above, but without agar, contained in a $15-\mathrm{mL}$ Falcon tube. The tube was incubated in a SHAKER (SL $222 \mathrm{SOLAB} 囚$ ) at $28^{\circ} \mathrm{C}$ and $150 \mathrm{rpm}$ for $96 \mathrm{~h}$.

\subsection{Culture of microorganisms for the production of endoglucanase and $\beta$-glucosidase}

After 96 hours of growth, a 2-mL sample was withdrawn from the inoculum and the optical density was measured at $600 \mathrm{~nm}$ in a Lambda Bio PERKINELMER ${ }^{\circledR}$ spectrophotometer. The inoculum was then added to an Erlenmeyer flask containing $190 \mathrm{~mL}$ of the medium described above (without agar) and incubated in a SHAKER (SL 222 SOLAB®) at $28^{\circ} \mathrm{C}$ and $150 \mathrm{rpm}$ for 240 hours. Two-mL aliquots were withdrawn at 24-hour intervals and centrifuged at $10,000 \mathrm{rpm}$ for $10 \mathrm{~min}$ for evaluation of the production of endoglucanase and $\beta$-glucosidase.

\subsection{Evaluation of endoglucanase production}

Analysis of endo-1,4- $\beta$-glucanase activity was performed according the method modified from the International Union of Pure and Applied Chemistry (IUPAC) standard method, described by Ghose (1987). This method consists of hydrolysis of a solution of $1 \%$ CMC (Synth), followed by quantification of the soluble reducing sugars released over a given time 
interval. The concentration of reducing sugars was determined according to the method described by Miller (1959) using 3,5-dinitrosalicylic acid (DNS) (Miller, 1959). The reaction was performed in Falcon tubes $(15 \mathrm{~mL})$ containing $1000 \mu \mathrm{L}$ of $1 \%(w / v)$ CMC solution in 100 mmol.L-1 acetate buffer, $\mathrm{pH} 4.8$ and $1000 \mu \mathrm{L}$ of the enzyme extract. The mixture was incubated at $50^{\circ} \mathrm{C}$, aliquots of $200 \mu \mathrm{L}$ were withdrawn at 0 -, 15 - and 30-minute intervals, and $200 \mu \mathrm{L}$ of DNS was added. A reaction without the presence of the enzyme extract (blank) was prepared by the addition of $100 \mu \mathrm{L}$ DNS to $100 \mu \mathrm{L}$ of distilled water. Samples and blank were heated in a boiling water bath $\left(95 \pm 1^{\circ} \mathrm{C}\right)$ for 5 minutes, followed by cooling in an ice-water bath $\left(0 \pm 1^{\circ} \mathrm{C}\right)$ and the addition of $2 \mathrm{~mL}$ and $1 \mathrm{~mL}$ of distilled water to the sample and the blank, respectively. The absorbance was measured at $540 \mathrm{~nm}$ using an analytical glucose curve at concentrations of 0 to $1.6 \mathrm{mg} / \mathrm{mL}^{\text {in }} 0.2 \mathrm{mg} \mathrm{mL}^{-1}$ intervals as a reference (Figure 1).

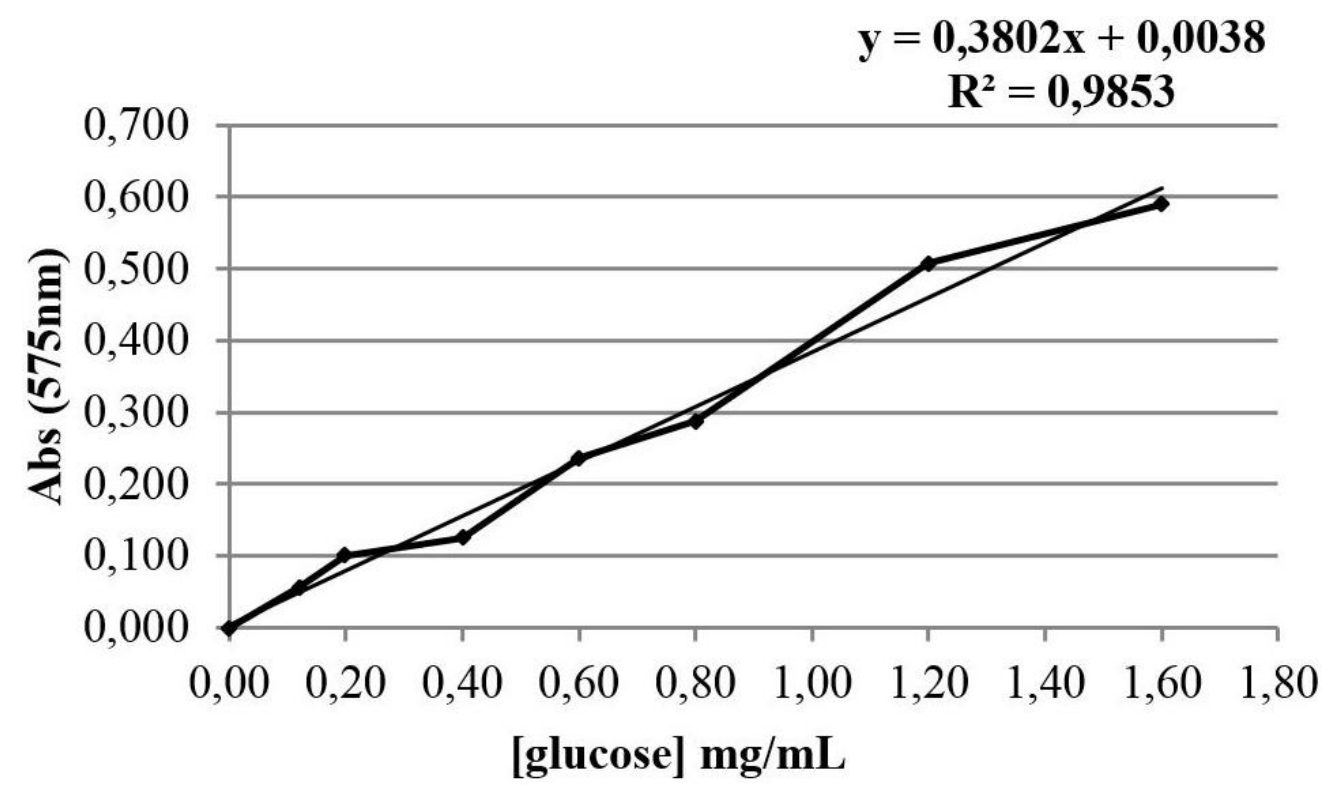

Figure 1. Analytical glucose curve.

One unit of endoglucanase activity was defined as the amount of enzyme capable of releasing $1 \mu \mathrm{mol}$ of reducing sugars, expressed as glucose, per minute per unit volume of enzyme extract. Data were submitted to analysis of variance considering a level of significance $(\alpha)$ of 0.05 using software ORIGIN PRO 8.

\subsection{Evaluation of $\beta$-glucosidase production}

The assay of $\beta$-glucosidase activity was implemented using the method modified from the International Union of Pure and Applied Chemistry (IUPAC) standard method, described by Ghose (1987), which involves hydrolysis of a $1 \%$ solution of cellobiose in $100 \mathrm{mmol} \mathrm{L}^{-1}$ citrate buffer at $\mathrm{pH} 4.8$ in the presence of the enzyme extract. The reaction medium was composed of $100 \mu \mathrm{L}$ of the substrate solution and $100 \mu \mathrm{L}$ of the enzyme extract in Eppendorf tubes. The tubes were incubated at $50^{\circ} \mathrm{C}$ in a water bath for 30 minutes, followed by boiling $\left(95 \pm 1^{\circ} \mathrm{C}\right)$ for $1 \mathrm{~min}$ and cooling in an ice bath. Aliquots of $15 \mu \mathrm{L}$ were removed for quantification of glucose using the standard enzymatic procedure employing glucose oxidase/peroxidase (GODPOD) (Lloyd and Whelan, 1969) with spectrophotometric measurement at $510 \mathrm{~nm}$. For each enzymatic reaction, one was prepared without the presence of the enzyme extract (blank), following the same procedure described for the sample. One unit of $\beta$-glucosidase activity was defined as the amount of enzyme capable of releasing $1 \mu \mathrm{mol}$ of glucose per minute of reaction, per unit volume (liter) of enzyme extract. Data were submitted to analysis of variance considering a level of significance $(\alpha)$ of 0.05 using software ORIGIN PRO 8. 


\section{RESULTS AND DISCUSSION}

\subsection{Profile of endoglucanase production}

The five strains of microorganisms selected according to the enzyme activity index (EAI) were grown in medium containing CMC as the main source of carbon, and they were monitored for $240 \mathrm{~h}$ for evaluation of endoglucanase and $\beta$-glucosidase activities, as shown in Figures $2 \mathrm{~A}$, $2 \mathrm{~B}, 3 \mathrm{~A}$ and $3 \mathrm{~B}$.

A

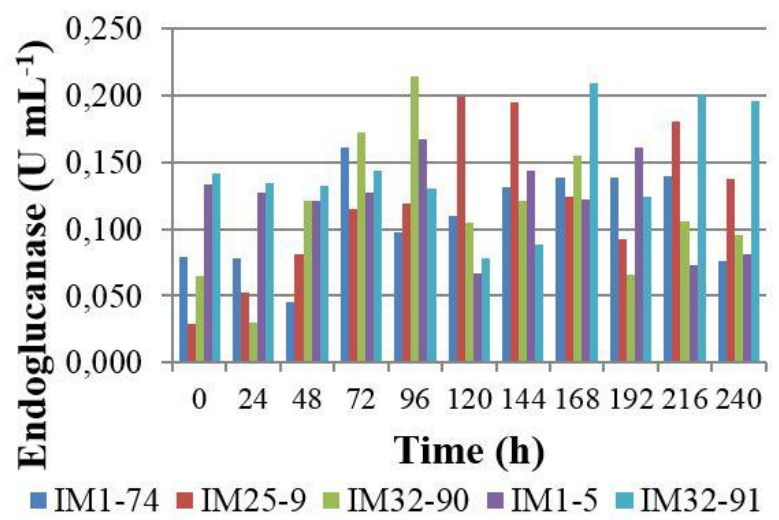

B

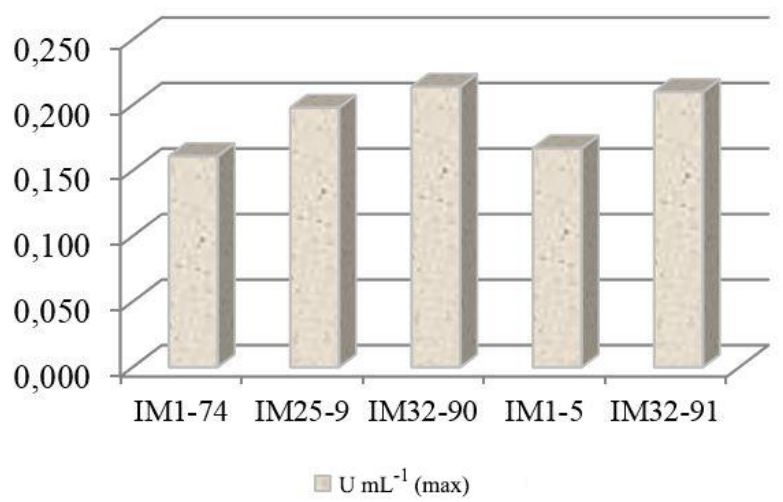

Figure 2. A: Punctual activities of endoglucanase from the five strains evaluated during 240 hours of culture. B: Maximum endoglucanase activity.

There is a relatively similar behavior for endoglucanase activities in all the strains (Figures $2 \mathrm{~A}$ and 2B). The highest endoglucanase activities (CMCase) were observed at 96 hours of fermentation with the microorganism IM32-90 $\left(0.214 \mathrm{U} \mathrm{mL}^{-1}\right), 120$ hours with IM25-9 (0.198 $\left.\mathrm{U} \mathrm{mL}^{-1}\right)$ and 168 hours with IM32-91 (0.210 $\left.\mathrm{U} \mathrm{mL}^{-1}\right)$.

In general, the enzymatic activities of endoglucanases in this work were similar to those of other organisms already studied, as in Yang et al. (2011), who observed $0.24 \mathrm{U} \mathrm{mL}^{-1}$ in a study that demonstrated the presence of Achromobacter xylosoxidans, Alcaligenes faecalis and Fusarium sporotrichioides. A similar result was also obtained by Mohapatra et al. (2018) when evaluating cellulase production by Aspergillus fumigatus isolated from decomposing cellulosic waste, showing a higher endoglucanase activity $\left(0.287 \mathrm{U} \mathrm{mL}^{-1}\right)$ obtained at $30^{\circ} \mathrm{C}$, which shows that the cellulase activity is active in this temperature range. Carvalho (2013) obtained $0.164 \mathrm{U} \mathrm{mL}^{-1}$ by cultivating Cryptococcus laurentii in medium supplemented with $2 \%$ wheat bran.

The analysis of variance showed that there was no significant difference at 0.05 between the endoglucanase production of the five microorganisms evaluated (Table 2).

Table 2. Analysis of variance (ANOVA) of the endoglucanase production by the five micro-organisms evaluated.

\begin{tabular}{lccccc}
\hline & DF & Sum of Squares & Mean Square & F Value & Prob $>F$ \\
\hline Model & 4 & 0.00947 & 0.00237 & 1.51983 & 0.24653 \\
Error & 15 & 0.02338 & 0.00156 & & \\
Total & 19 & 0.03285 & & & \\
\hline
\end{tabular}

One Way ANOVA

Overall ANOVA

Null Hypothesis: The means of all levels are equal.

Alternative Hypothesis: The means of one or more levels are different.

At the 0.05 level, the population means are not significantly different. 


\subsection{Profile of $\beta$-glucosidase production}

The production of $\beta$-glucosidase by the five selected strains was observed for 240 hours, as described in Figures $3 \mathrm{~A}$ and $3 \mathrm{~B}$.

A

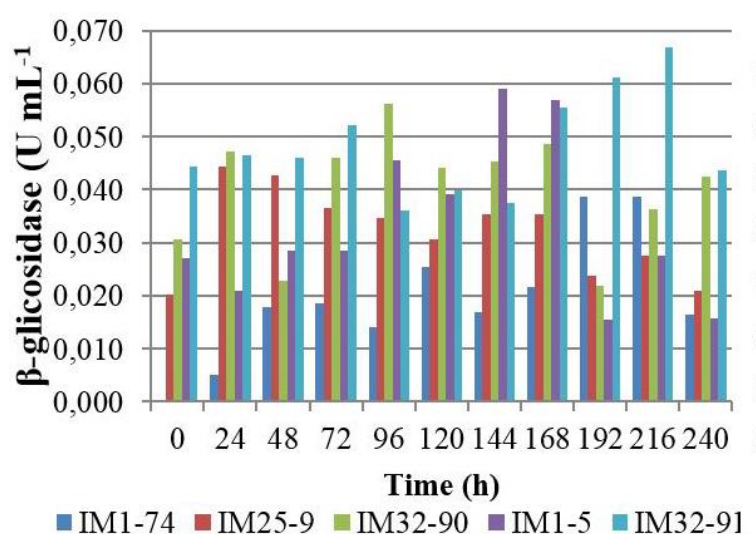

B

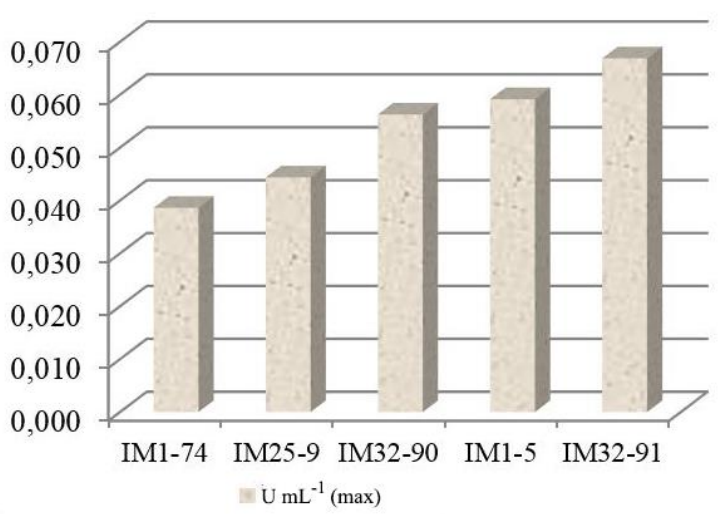

Figure 3. A: Punctual $\beta$-glucosidase activities of the five strains evaluated during 240 hours of culture. B: Maximum $\beta$-glucosidase activity.

The highest cellobiase activity $\left(0.067 \mathrm{U} \mathrm{mL}^{-1}\right)$ was observed for the IM32-91 strain after $216 \mathrm{~h}$ of culture, followed by the IM1 -5 strain $\left(0.059 \mathrm{U} \mathrm{mL}^{-1}\right)$ at $144 \mathrm{~h}$ of culture. After $216 \mathrm{~h}$ of fermentation, the cellobiase activity of strain IM32-91 began to decrease. The IM1-74 strain with the highest enzymatic activity index $($ EAI $=22)$ had the lowest endoglucanase $\left(0.161 \mathrm{U} \mathrm{mL}^{-1}\right)$ and $\beta$-glucosidase $\left(0.039 \mathrm{U} \mathrm{mL}^{-1}\right)$ activities in liquid medium, as is shown in Table 3.

Table 3. Enzymatic activity indices expressed in solid medium and endoglucanase and $\beta$-glucosidase activity of the five strains evaluated in liquid medium.

\begin{tabular}{lccc}
\hline Strain & EAI & Endoglucanase $\left(\mathbf{U ~ m L}^{-\mathbf{1}}\right)$ & $\boldsymbol{\beta}$-Glucosidase $\left(\mathbf{U ~ m L}^{-\mathbf{1}}\right)$ \\
\hline IM1-74 & 22.00 & 0.161 & 0.039 \\
IM25-9 & 5.33 & 0.198 & 0.044 \\
IM32-90 & 7.33 & 0.214 & 0.056 \\
IM1-5 & 10.33 & 0.167 & 0.059 \\
IM32-91 & 5.44 & 0.210 & 0.067 \\
\hline
\end{tabular}

The analysis of variance showed that there was no significant difference at 0.05 between the $\beta$-glucosidase production of the five microorganisms evaluated (Table 4).

Table 4. Analysis of variance (ANOVA) of the $\beta$-glucosidase production by the five microorganisms evaluated.

\begin{tabular}{lccccc}
\hline & DF & Sum of Squares & Mean Square & F Value & Prob $>F$ \\
\hline Model & 4 & 0.002 & $4.99157 \mathrm{E}-4$ & 1.0913 & 0.41185 \\
Error & 10 & 0.00457 & $4.57398 \mathrm{E}-4$ & & \\
Total & 14 & 0.00657 & & & \\
\hline
\end{tabular}

One Way ANOVA

Overall ANOVA

Null Hypothesis: The means of all levels are equal.

Alternative Hypothesis: The means of one or more levels are different.

At the 0.05 level, the population means are not significantly different. 
The IM32-91 strain, which has one of the lowest levels of enzymatic activity among the selected microorganisms $(E A I=5.44)$, was the best producer of $\beta$-glucosidase $\left(0.067 \mathrm{U} \mathrm{mL}^{-1}\right)$ and the second best producer of endoglucanase $\left(0.210 \mathrm{U} \mathrm{mL}^{-1}\right)$. The highest endoglucanase production was observed for strain IM32-90 $\left(0.214 \mathrm{U} \mathrm{mL}^{-1}\right)$. The values of $\beta$-glucosidase production were very satisfactory compared to those found by Vyas and Chhabra (2017), who cultivated the yeast Cystobasidium oligophagum in a medium containing CMC as carbon source under the same conditions and obtained $0.031 \mathrm{U} \mathrm{mL}^{-1}$ after 72 hours of incubation. Priyanka et al. (2017) obtained $0.077 \mathrm{U} \mathrm{mL}^{-1}$ endoglucanase as the maximum value produced by the fungus Paecilomyces variotii when testing different concentrations of CMC as a carbon source. This value was about three times less than the maximum value obtained in this work for endoglucanase $\left(0.214 \mathrm{U} \mathrm{mL}^{-1}\right)$.

CMC is considered to be a better substrate for cellulase production due to its soluble nature compared to other carbon sources, demonstrating its effectiveness in this work (Sohail et al.; 2016).

The production of cellulolytic enzymes can be increased by changes in culture medium conditions, such as supplementation of the culture medium and the use of recombinant microorganisms. Anusree et al. (2016) cultured recombinant Corynebacterium glutamicum bacteria with Xanthomonas campestre genes to evaluate the production of endoglucanase and Saccharophagus degradans for the production of $\beta$-glucosidase in medium supplemented with $20 \mathrm{~g} . \mathrm{L}^{-1}$ of CMC. They obtained $8 \pm 0.4 \mathrm{U} \mathrm{mL}^{-1}$ of $\beta$-glucosidase and $4.5 \pm 0.2 \mathrm{U} \mathrm{mL}^{-1}$ of endoglucanase. In medium supplemented with 20 g.L $\mathrm{L}^{-1}$ of cellobiose, they obtained $9.0 \pm 0.5 \mathrm{U} \mathrm{mL}^{-1}$ of $\beta$-glucosidase and $2 \pm 0.13 \mathrm{U} \mathrm{mL}^{-1}$ of endoglucanase. The strains evaluated in this work will be submitted for molecular identification.

The analysis of variance (ANOVA) with significance level 0.05 (Tables 2 and 4) showed that there was no significant difference in the production of endoglucanase and $\beta$-glucosidase by the five cellulase-producing microorganisms evaluated. These results indicate that any of the organisms evaluated can be used for the production of these enzymes, and their production processes may be optimized in future works.

\section{CONCLUSION}

The five strains evaluated were effective for cellulase production, presenting hydrolytic activities in carboxymethylcellulose and cellobiose, and proving that they are promising tools for the production of these enzymes. Further studies should be performed to increase cellulolytic capacity and enzyme extraction for commercial application.

\section{ACKNOWLEDGMENTS}

To Aperam Bioenergy LTDA, FAPEMIG, CNPq, CAPES and UFVJM for logistical and financial support to perform this work.

\section{REFERENCES}

ADITIYA, H. B.; MAHLIA, T. M. I.; CHONG, W. T.; NUR, H.; SEBAYANG, A. H. Second generation bioethanol production: A critical review. Renewable and Sustainable Energy Reviews, v. 66, p. 631-653, 2016. http://dx.doi.org/10.1016/j.rser.2016.07.015

ANUSREE, M.; WENDISCH, V. F.; NAMPOOTHIRI, K. M. Co-expression of endoglucanase and $\beta$-glucosidase in Corynebacterium glutamicum DM1729 towards direct lysine fermentation from cellulose. Bioresource Technology, v. 213, p. 239-244, 2016. https://doi.org/10.1016/j.biortech.2016.03.019 
BEHERA, B. C.; SETHI, B. K.; MISHRA, R. R; DUTTA, S. K.; THATOI, H. N. Microbial cellulases - Diversity \& biotechnology with reference to mangrove environment: A review. Journal of Genetic Engineering and Biotechnology, v. 15, p. 197-210, 2017. https://doi.org/10.1016/j.jgeb.2016.12.001

CARVALHO, F. P. Cellulolytic and xylanolytic enzymes from yeasts isolated from the cerrado. 2013. 118 p. Thesis (Doctoral) - Federal University of Lavras, Lavras, 2013.

CERDA, A.; MEJÍAS, L.; GEA, T.; SÁNCHEZ, A. Cellulase and xylanase production at pilot scale by solid-state fermentation from coffee husk using specialized consortia: The consistency of the process and the microbial communities involved. Bioresource Technology, v. 243, p. 1059-1068, 2017. https://doi.org/10.1016/j.biortech.2017.07.076

CHOUDHARY, J.; SINGH, S.; NAIN, L. Bioprospecting thermotolerant ethanologenic yeasts for simultaneous saccharification and fermentation from diverse environments. Journal of Bioscience and Bioengineering, v. 123, n. 3, p. 342 - 346, 2017. https://doi.org/10.1016/j.jbiosc.2016.10.007

DODDA, S. R.; AICH, A.; SARKAR, N.; JAIN, P.; JAIN, S.; MONDAL, S.; AIKA, T. K.; MUKHOPADHYAY, S. S. Structural and functional insights of $\beta$-glucosidases identified from the genome of Aspergillus fumigatus. Journal of Molecular Structure, v. 1156, p. 105-114, 2018. https://doi.org/10.1016/j.molstruc.2017.11.078

GHOSE, T. K. Measurement of cellulose activities. Pure and Applied Chemistry, v. 59, p. 257-268, 1987. https://doi.org/10.1351/pac198759020257

IDRIS, A. S. O.; PANDEY, A.; RAO, S. S.; SUKUMARAN, R. K. Cellulase production through solid-state tray fermentation, and its use for bioethanol from sorghum stover. $\begin{array}{llllll}\text { Bioresource } & \text { Technology, } & \text { v. 242, p. 265-271, }\end{array}$ https://doi.org/10.1016/j.biortech.2017.03.092

LI, S.; YANG, X.; YANG, S.; ZHU, M.; WANG, X. Technology Prospecting on Enzymes: Application, Marketing and Engineering. Computational and Structural Biotechnology Journal, v. 2, n. 3, p. 1-11, 2012. https://doi.org/10.5936/csbj.201209017

LLOYD, J. B.; WHELAN, W. J. An improved method for enzymic determination of glucose in the presence of maltose. Analytical Biochemistry, v. 30, p. 467-470, 1969. http://dx.doi.org/10.1016/0003-2697(69)90143-2

LUCARINI, A. C.; DELQUIARO, A. C. T.; VIDOCA, L. C. P. T.; BRAZ, R.; MARTINS, R. M.; ALVEZ, T. P. Study of enzymatic hydrolysis of sugar cane straw for the production of ethanol. The Journal of Engineering and Exact Sciences - JCEC, v. 3, n. 2, p. 242253, 2017. https://doi.org/10.18540/jcecvl3iss2pp242-253

MILLER, G. L. Use of dinitrosalicylic acid reagent for determination of reducing sugar. Analytical Chemistry, v. 31, p. 426-428, 1959. https://doi.org/10.1021/ac60147a030

MOHAPATRA, S.; PADHY, S.; MOHAPATRA, P. K. D.; THATOI, H. N. Enhanced reducing sugar production by saccharification of lignocellulosic biomass, Pennisetum species through cellulose from a newly isolated Aspergillus fumigatus. Bioresource Technology, v. 253, p. 262-272, 2018. https://doi.org/10.1016/j.biortech.2018.01.023

OBENG, E. M.; BUDIMAN, C.; ONGKUDON, C. M. Identifying additives for cellulase enhancement-A systematic approach. Biocatalysis and Agricultural Biotechnology, v. 11, p. 67-74, 2017. https://doi.org/10.1016/j.bcab.2017.06.006

Rev. Ambient. Água vol. 14 n. 4, e2324 - Taubaté 2019 
PRIYANKA, P.; YUVRAJ, C.; FARHA, S.; ARANGANATHAN, V. Isolation of cellulose degrading fungi from soil and optimization for cellulase production using carboxymethylcellulose. International Journal of Life Science \& Pharma Research, v. 7, p. 56-60, 2017.

SOHAIL, M.; AHMAD, A.; KHAN, S. A. Production of cellulase from Aspergillus terreus MS105 on crude and commercially purified substrates. 3 Biotech, v, 6, p. 103, 2016. https://dx.doi.org/10.1007/s13205-016-0420-z

SQUINCA, P.; BADINO, A. C.; FARINAS, C. S. A closed-loop strategy for endoglucanase production using sugarcane bagasse liquefied by a home-made enzymatic cocktail. $\begin{array}{llllll}\text { Bioresource } & \text { Technology, v. 249, p. 976-982, } 2018 .\end{array}$ https://doi.org/10.1016/j.biortech.2017.10.107

SRIVASTAVA, N.; SRIVASTAVA, M.; MISHRA, P. K.; GUPTA, V. K.; MOLINA, G.; RODRIGUEZ-COUTO, S.; MANIKANTA, A.; RAMTEKE, P. W. Applications of fungal cellulases in biofuel production: Advances and limitations. Renewable and Sustainable Energy Reviews, v. 82, p. 2379-2386, 2018. https://doi.org/10.1016/j.rser.2017.08.074

TOOGOOD, H. S.; SCRUTTON, N. S. Retooling microorganisms for the fermentative production of alcohols. Current Opinion of Biotechnology, v. 50, p. 1-10, 2018. http://dx.doi.org/10.1016/j.copbio.2017.08.010

VYAS, S.; CHHABRA, M. Isolation, identification and characterization of Cystic Basidium oligophagum JRC1: a cellulase and lipase producing oleaginous yeast. Bioresource Technology, v. 223, p. 250-258, 2017. https://dx.doi.org/10.1016/j.biortech.2016.10.039

YANG, H.; WU, H.; WANG, X.; CUI, Z.; LI, Y. Selection and characteristics of a switchgrasscolonizing microbial community to produce extracellular cellulases and xylanases. Bioresource Technology, v. 102, n. 3, p. $3546 \quad-\quad 3550,2011$. https://doi.org/10.1016/j.biortech.2010.09.009 


Ambiente \& Água - An Interdisciplinary Journal of Applied Science
ISSN 1980-993X - doi:10.4136/1980-993X
www.ambi-agua.net
E-mail: ambi.agua@gmail.com

\title{
Genesis of sandstone-derived soils in the Cerrado of the Piauí State, Brazil
}

\author{
ARTICLES doi:10.4136/ambi-agua.2355
}

Received: 04 Dec. 2018; Accepted: 26 May 2019

\author{
Diego Ferreira de Souza1 ${ }^{1}$; Ronny Sobreira Barbosa ${ }^{1}$; \\ Yuri Jacques Agra Bezerra da Silva ${ }^{1}$; Márcio Cleto Soares de Moura ${ }^{2}$; \\ Romário Porto de Oliveira1 ${ }^{1 D}$; Vanessa Martins ${ }^{3 * \text { (D) }}$ \\ ${ }^{1}$ Universidade Federal do Piauí (UFPI), Bom Jesus, PI, Brasil \\ Programa de Pós-Graduação em Ciências Agrárias. \\ E-mail: agrodiegoufpi@ hotmail.com, ronny.barbosa@ufpi.edu.br, \\ yuri_jacques@hotmail.com, rportoo55@ @otmail.com \\ ${ }^{2}$ Universidade Federal do Piaú (UFPI), Teresina, PI, Brasil \\ Centro de Ciências da Natureza (CCN). E-mail: marcio@ufpi.edu.br \\ ${ }^{3}$ Universidade Federal do Piaú (UFPI), Bom Jesus, PI, Brasil \\ Colégio Técnico de Bom Jesus (CTBJ). E-mail: nessaufla@yahoo.com.br \\ *Corresponding author
}

\begin{abstract}
This study characterized the morphological, physical and chemical attributes of sandstonederived soils at the Cerrado of the Piauí State, Brazil, in order to identify evolutionary standards. The study was carried out with five representative soil profiles identified as P1-RY (Typical Flavic Psychotic Neosol - Aquents), P2-PA (Typical Dystrophic Yellow Argisol - Alfisol), P3RL (Fragmentary Litholic Distrophic Neosol - Psammenit), P4-RQ (Typical Ortic Quartzenetic Neosol - Orthents) and P5-PV (Typical Dystrophic Red Argisol - Ultisol). Soil samples were submitted laboratory analysis described morphologically. In general, the soils presented high sand content, low $\mathrm{pH}$, low content of exchangeable bases and low cation exchange capacity (CEC). Organic matter governed the CEC in most cases, suggesting dependence of organic matter in the supply of charges. These soils showed a low degree of weathering, but with iron of high crystallinity. Thus, the relief and the parent material are the major important soilforming factors at the Cerrado of the Piauí State. Moreover, these soils are young, with the soils from the Piauí Formation being more evolved. However, the sandstones from the Canindé Group apparently are providing lithological secondary minerals for the soil.
\end{abstract}

Keywords: sand-loam soils, tropical soils, weathering indexes.

\section{Gênese de solos derivados de arenitos no Cerrado Piauiense, Brasil}

\section{RESUMO}

Objetivou-se com este trabalho caracterizar atributos morfológicos, físicos e químicos de solos formados a partir de arenitos no Cerrado Piauiense, na tentativa de encontrar padrões evolutivos. O estudo foi realizado em cinco perfis de solos representativos identificados como P1-RY (Neossolo Flúvico Psamítico típico - Aquents), P2-PA (Argissolo Amarelo Distrófico típico - Alfisol), P3-RL (Neossolo Litólico Distrófico fragmentário - Psamments), P4-RQ 
(Neossolo Quartzarênico Órtico típico - Orthents) e P5-PV (Argissolo Vermelho Distrófico Típico - Ultisol). As amostras dos solos foram submetidas à descrição morfológica e análises laboratoriais. Em geral, os solos desta região apresentaram altos teores da fração areia, baixo $\mathrm{pH}$, baixo conteúdo de bases trocáveis e baixa capacidade de troca catiônica (CTC). A matéria orgânica governou a CTC na maioria dos horizontes, sugerindo uma dependência da matéria orgânica no fornecimento de cargas. Estes solos mostraram baixo grau de intemperismo, mas com ferro de alta cristalinidade. Assim, é possível afirmar que o relevo e o material de origem são os fatores de formação do solo que possuem maior influência nos atributos dos solos do Cerrado Piauiense, Brasil. Além disso, estes solos são jovens, sendo os mais evoluídos aqueles originados da Formação Piauí. Contudo, os arenitos do grupo Canindé aparentemente estão fornecendo minerais secundários diretamente da rocha ao solo.

Palavras-chave: índices de intemperismo, solos franco-arenosos, solos tropicais.

\section{INTRODUCTION}

The Cerrado biome is home to the main thrust of Brazilian agricultural expansion. Its climate and soil characteristics are very diverse. The soils of the Brazilian Cerrado evolve from rocks that go back from Pre-Cambrian to Cenozoic (Pfaltzgraff, 2010). The relief exhibits a very large range of morphological features distributed at different altitudes, constituting welldefined units, among which stand out plateaus, depressions, and plains. Soils consist of representative units of more than a dozen classes and are mostly dystrophic and acid (Pfaltzgraff, 2010).

In the state of Piauí, this biome occupies approximately 11.5 million hectares and is worldrenowned for its economic importance as a reflection of its imminent agricultural expansion (Pragana et al., 2012). There is also noticeable soil variability at different levels when compared with the Cerrado of other Brazilian regions. This variability, which occurs in response to the interaction between the soil formation factors, suggests major challenges for a conscious agricultural production.

The particularities of each site must be considered to facilitate the use of natural resources in agricultural activities. According to Buol et al. (2011), soil genesis and classification can permit better and more concise recommendations for soil use. Since weathering is directly related to the soil genesis, Kehrig (1949) reported that using weathering indexes such as Ki and $\mathrm{Kr}$ is a great option to explore soil genesis, considering the lack of more accurate information provided by $\mathrm{x}$-ray diffractometry.

In the Cerrado of Piauí, most farmers consider general information about the soils for the adoption of management systems. Most of them assume that the soil belongs to the order of the Oxisols, with not only the same weathering level but also characteristics of soils from other places (i.e. soils in the south and southeast regions). This inevitably causes errors since not every soil in this region has the same level of weathering and homogeneity due to the landscape often observed in the Cerrado of Piauí State. Negative reflections of these deductions are amplified due to the sedimentary nature of the parent material of these soils, in addition to the climate intensity to which they are submitted each year, which demand more and more soil performance.

To correct this, the first steps involve soil characterization, recognizing that the evolution of each one soil is inherently tied to its formation environment. Thus, this study characterized the morphological, physical and chemical attributes of sandstone-derived soils at the Cerrado of the Piauí State in order to identify evolutionary standards.

Rev. Ambient. Água vol. 14 n. 4, e2355 - Taubaté 2019 


\section{MATERIAL AND METHODS}

\subsection{Study area}

This research was carried out using five representative soils of the Upper Middle Gurguéia micro-region, at the Cerrado of the Piauí State, Brazil (Figure 1). The regional relief is craggy, with a warm and humid tropical climate, classified as Aw according to the Köppen classification. Historical data from the last 44 years, 1973 to 2017, show that the mean values of minimum and maximum temperatures are 20.3 and $33.6^{\circ} \mathrm{C}$, respectively, and the mean annual precipitation is $939 \mathrm{~mm}$ (Inmet and Bdmet, 2017).

In order to represent as much as possible the environments of the study area, the sampling sites were chosen based on its geodiversity map (Pfaltzgraff, 2010). At each site, a trench was opened to expose the profiles of the studied soils, a procedure described by Santos et al. (2015) in areas under native Cerrado. Soil horizons were collected and identified according to Santos et al. (2015).

The study was carried out in five representative soil profiles identified as P1-RY (Typical Flavic Psychotic Neosol - Aquents), P2-PA (Typical Dystrophic Yellow Argisol - Alfisol), P3RL (Fragmentary Litholic Distrophic Neosol - Psamments), P4-RQ (Typical Ortic Quartzenetic Neosol - Orthents) and P5-PV (Typical Dystrophic Red Argisol - Ultisol).

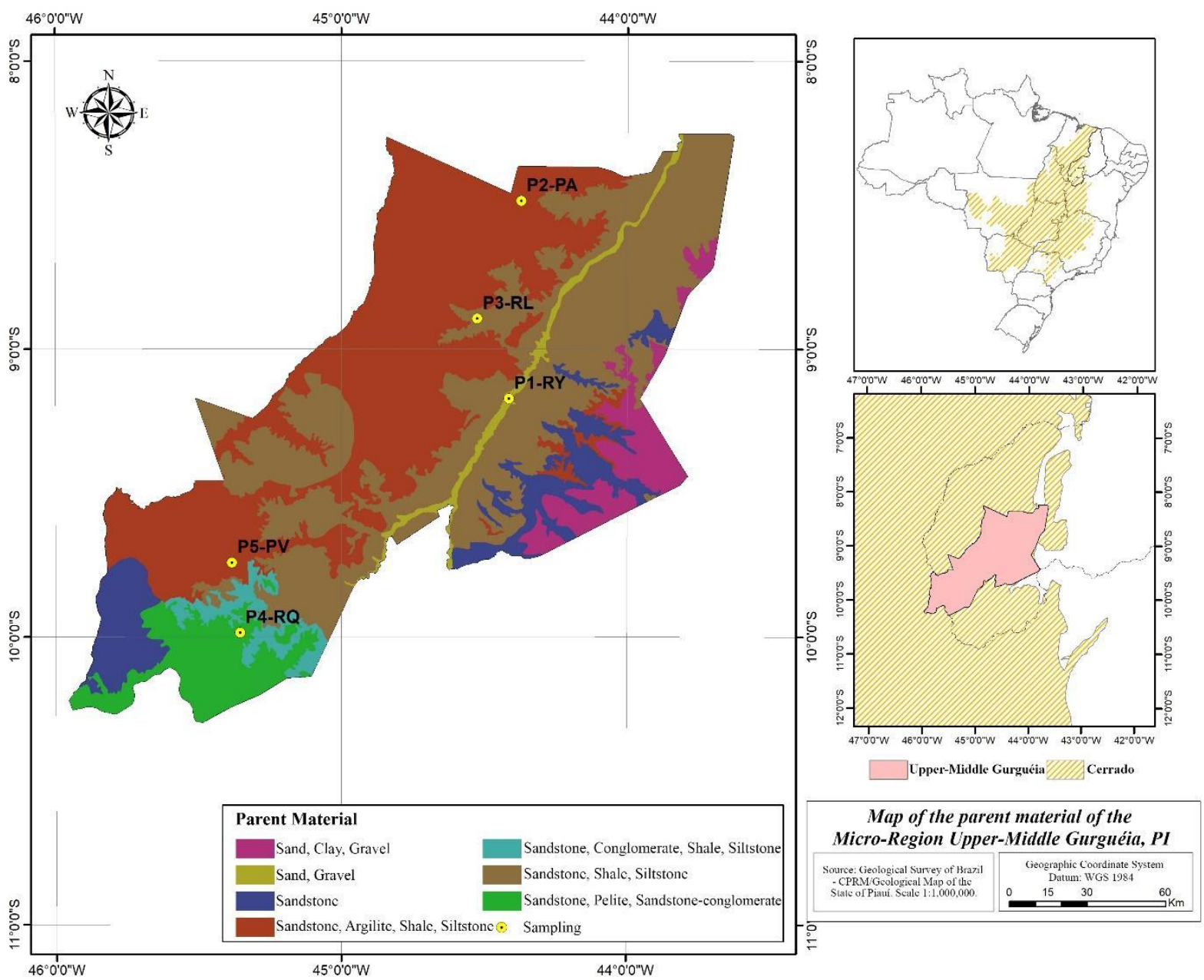

Figure 1. Study area location with indication of the sampling sites (profiles) on the parent material map.

The P1-RY is located at the flood plain and was developed under unconsolidated sediments (sand and gravel) of Cenozoic origin (Pfaltzgraff, 2010). The P2-PA and P5-PV were derived 
from sandstone (Piauí Formation, Balsas Group) of Paleozoic origin. The P2-PA is located at the crest, whereas the soil P5-PV is on the shoulder (Pfaltzgraff, 2010).

The P3-RL was also derived from sandstone (Piauí Formation, Canindé Group), but it is positioned at the side slope (Pfaltzgraff, 2010). The P4-RQ is located at the toe slope and was derived from sandstone (Mesozoic origin, Urucuia Complex) (Pfaltzgraff, 2010).

\subsection{Physical and chemical analyzes}

The samples from each horizon or layer were air-dried and subsequently declotted, homogenized, sieved in a stainless steel sieve with a $2.00 \mathrm{~mm}$ mesh, and used for the physical and chemical analyses. The particle size distribution was performed using $0.1 \mathrm{~mol} \mathrm{~L}^{-1} \mathrm{NaOH}$ solution as a dispersant under slow stirring and the clay content was determined by the pipette method (Teixeira et al., 2017). The clay dispersed in water (CDW) and the degree of flocculation were obtained according to Teixeira et al. (2017).

The $\mathrm{pH}$ in water and $\mathrm{KCl}$, potential acidity $(\mathrm{H}+\mathrm{Al})$, calcium $\left(\mathrm{Ca}^{2+}\right)$, magnesium $\left(\mathrm{Mg}^{2+}\right)$, potassium $\left(\mathrm{K}^{+}\right)$, and aluminum $\left(\mathrm{Al}^{3+}\right)$ were obtained using the methodologies proposed by Raij et al. (2001). The $\mathrm{P}$ and organic carbon $\left(\mathrm{C}_{\text {org }}\right)$ contents were analyzed using the methodology recommended by Teixeira et al. (2017). The values equivalent to the sum of bases (SB), cation exchange capacity (CEC), base saturation (V), and aluminum saturation (m) were obtained by calculations proposed by Teixeira et al. (2017).

\subsection{Sulfuric attack, weathering indexes and crystallinity of iron oxides}

Topsoil samples of all profiles were used for analyses of sulfuric attack and crystallinity of iron oxides. Only the samples of the subsurface diagnostic horizons of the P2-PA (Bt1) and P5-PV (Bt) were used for that. In the total sulfuric attack, the samples were treated with $\mathrm{H}_{2} \mathrm{SO}_{4}$ to extract the total contents of iron $\left(\mathrm{Fe}_{2} \mathrm{O}_{3}\right)$ and aluminum $\left(\mathrm{Al}_{2} \mathrm{O}_{3}\right)$ oxides, followed by alkaline dissolution for silicon $\left(\mathrm{SiO}_{2}\right)$ and titanium $\left(\mathrm{TiO}_{2}\right)$ oxides according to Teixera et al. (2017). These values were used to calculate the weathering indexes $\mathrm{Ki}$ and $\mathrm{Kr}$ as suggested by Kehrig (1949).

The free iron oxides $\left(\mathrm{Fe}_{\mathrm{d}}\right)$ were extracted with citrate-dithionite-bicarbonate (Mehra and Jackson, 1960) and the poorly crystallized iron $\left(\mathrm{Fe}_{\mathrm{o}}\right)$ was extracted with acid ammonium oxalate according to the methodology described by Camargo et al. (2009) adapted from Schwertmann (1973).

\section{RESULTS AND DISCUSSION}

\subsection{Soil Morphology}

The soil P1-RY presented the horizons A-2C1-3C2-4C3-5C4-6C5-7C6-8C7-9C8 formed by lithological discontinuity along a $2.0 \mathrm{~m}$ depth (Table 1 ). These layers show heterogeneity, among others, in the texture and color of the material that makes up the solid phase of the soil, denoting no or little relation to each other. This discontinuity is caused by the deposition of sediments in the Holocene period that occurs yearly during the wet season, which provides water presence on the surface. Darker shades in these layers are indicative of an erratic organic matter distribution (Demattê et al., 2011). Silva et al. (2017) studied profiles of a landscape in the Brazilian Cerrado and also found in the flood plain a profile with color variability.

The P2-PA and P5-PV soil profiles showed the diagnostic horizon know as Bt, coherent with the Argissolos (Ultisol) class (Santos et al., 2018) (Table 1). The P2-PA has a yellowish hue (5Y), whereas the soil P5-PV has reddish hue (10R to 2.5YR), which probably reflects differences related to the goethite and hematite contents. Both P2-PA and P5-PV have differences along their depths, being P2-PA more developed. Apparently, the P5-PV evolved through soil-erosion processes often observed in soils located at the slopes of the landscape (Buol et al., 2011). 
Table 1. Morphological description of the profiles studied.

\begin{tabular}{|c|c|c|c|c|c|c|c|}
\hline \multirow{2}{*}{ Horizon } & \multirow{2}{*}{ Depth (m) } & \multirow{2}{*}{$\begin{array}{c}\text { Color } \\
\text { (moisture) }\end{array}$} & \multirow{2}{*}{ Structure $^{\mathrm{a}}$} & \multicolumn{3}{|c|}{ Consistency } & \multirow{2}{*}{ Transition $^{\mathrm{b}}$} \\
\hline & & & & Dry & Moisture & $\mathrm{Wet}^{\mathrm{c}}$ & \\
\hline \multicolumn{8}{|c|}{ P1-RY } \\
\hline $\mathrm{A}$ & $0-0.15$ & $5 Y R 4 / 3$ & S; Sm; e SubBlo & Slightly hard & Friable & $\mathrm{Npl} / \mathrm{St}$ & Grad e Fla \\
\hline $2 \mathrm{C} 1$ & $0.15-0.35$ & $5 Y R 6 / 6$ & $\mathrm{Sg} ; \mathrm{T}$ e Granu & Slightly hard & Friable & $\mathrm{Npl} / \mathrm{St}$ & Grad e Fla \\
\hline $3 \mathrm{C} 2$ & $0.35-0.45$ & $7.5 Y R 7 / 6$ & Sg; T e Granu & Slightly hard & Friable & $\mathrm{Npl} / \mathrm{St}$ & Abr e Fla \\
\hline $4 \mathrm{C} 3$ & $0.45-0.80$ & $7.5 Y R 7 / 6$ & Sg; T e Granu & Slightly hard & Friable & $\mathrm{Spl} / \mathrm{St}$ & Grad e Fla \\
\hline $5 \mathrm{C} 4$ & $0.80-1.10$ & $5 Y R 5 / 4$ & S; grande e SubBlo & Slightly hard & Friable & $\mathrm{Spl} / \mathrm{St}$ & Abr e Fla \\
\hline $6 \mathrm{C} 5$ & $1.10-1.30$ & 5YR 5/ & Mo; Sm; e SubBlo & Slightly hard & Friable & Spl / Stk & Abr e Rip \\
\hline $7 \mathrm{C6}$ & $1.30-1.40$ & $5 Y R 5 / 4$ & Mo; T e SubBlo & Slightly hard & Friable & Spl / Stk & Grad e Fla \\
\hline $8 \mathrm{C} 7$ & $1.40-1.60$ & 7.5 YR $6 / 8$ & Sg; T e SubBlo & Slightly hard & Friable & $\mathrm{Spl} / \mathrm{St}$ & Grad e Fla \\
\hline $9 \mathrm{C} 8$ & $1.60-2.00+$ & 7.5YR 6/8 & Sg; T e SubBlo & Slightly hard & Friable & $\mathrm{Spl} / \mathrm{St}$ & - \\
\hline \multicolumn{8}{|c|}{$\mathrm{P} 2-\mathrm{PA}$} \\
\hline $\mathrm{A}$ & $0-0.20$ & $5 Y 2.5 / 2$ & Mo; T e SubBlo & Slightly hard & Friable & $\mathrm{Npl} /$ Stk & $\mathrm{Cle}$ \\
\hline $\mathrm{AB}$ & $0.20-0.35$ & $5 Y 5 / 2$ & Mo; Sm; e SubBlo & Slightly hard & Friable & $\mathrm{Npl} / \mathrm{St}$ & Grad \\
\hline $\mathrm{BA}$ & $0.35-0.60$ & $5 Y 7 / 4$ & Mo; Sm; e SubBlo & Slightly hard & Friable & $\mathrm{Npl} / \mathrm{St}$ & Dif \\
\hline Bt1 & $0.60-1.10$ & $5 Y 7 / 6$ & Mo; Sm; e Granu & Slightly hard & Friable & $\mathrm{Spl} / \mathrm{St}$ & Dif \\
\hline $\mathrm{Bt} 2$ & $1.10-2.10+$ & $5 Y 7 / 6$ & Mo; Sm; e Granu & Slightly hard & Friable & $\mathrm{Spl} / \mathrm{St}$ & - \\
\hline \multicolumn{8}{|c|}{ P3-RL } \\
\hline $\mathrm{A}$ & $0-0.10$ & 7.5YR 3/1 & W; Sm; e Granu & Slightly hard & Friable & $\mathrm{Spl} / \mathrm{St}$ & Abr e Des \\
\hline CR & $0.10-0.40$ & 7.5YR 3/1 & W; Sm; e Granu & Slightly hard & Firm & $\mathrm{Spl} / \mathrm{St}$ & - \\
\hline \multicolumn{8}{|c|}{ P4-RQ } \\
\hline A1 & $0-0.20$ & $5 Y R$ 4/4 & W; Sm; e SubBlo & Soft & Very friable & $\mathrm{Npl} / \mathrm{NStk}$ & Dif e Fla \\
\hline $\mathrm{A} 2$ & $0.20-0.55$ & 5YR 5/6 & W; Sm; e SubBlo & Soft & Very friable & $\mathrm{Npl} / \mathrm{NStk}$ & Grad e Fla \\
\hline $\mathrm{C} 1$ & $0.55-1.13$ & $5 Y R 6 / 8$ & W; Sm; e SubBlo & Soft & Very friable & $\mathrm{Npl} /$ NStk & Cle e Fla \\
\hline $\mathrm{C} 2$ & $1.13-2.00+$ & $5 Y R 6 / 8$ & W; Sm; e SubBlo & Soft & Very friable & Npl / NStk & - \\
\hline \multicolumn{8}{|c|}{ P5-PV } \\
\hline $\mathrm{A}$ & $0-0.20$ & $2.5 Y R 3 / 6$ & S; Med e SubBlo & Slightly hard & Friable & $\mathrm{Spl} / \mathrm{St}$ & Fla e Cle \\
\hline $\mathrm{BA}$ & $0-20-0.30$ & $2.5 \mathrm{YR} 4 / 6$ & S; Med e SubBlo & Hard & Firm & $\mathrm{Spl} / \mathrm{St}$ & Fla e Cle \\
\hline $\mathrm{Bt}$ & $0.30-0.85$ & $10 \mathrm{R} 4 / 8$ & S; Med e SubBlo & Hard & Firm & $\mathrm{Spl} / \mathrm{St}$ & Fla e Cle \\
\hline $\mathrm{BC}$ & $0.85-1.10$ & $10 \mathrm{R} 4 / 8$ & S; Med e SubBlo & Hard & $\begin{array}{l}\text { Extremely } \\
\text { firm }\end{array}$ & $\mathrm{Spl} / \mathrm{St}$ & Fla e Cle \\
\hline $\mathrm{CR}$ & $1.10-1.30$ & $10 \mathrm{R} 3 / 6$ & S; grande e SubBlo & Too Hard & $\begin{array}{l}\text { Extremely } \\
\text { firm }\end{array}$ & $\mathrm{Spl} / \mathrm{St}$ & - \\
\hline
\end{tabular}

aS, Strong; W, Weak; Mo, Moderate; Sg, Simple grains; T, Tiny; Sm, Small; Med, Medium; SubBlo, Subangular Blocks; Granu, Granular. ${ }^{\text {b } G r a d, ~ G r a d u a l ; ~ D i f, ~ D i f f u s e ; ~ A b r, ~ A b r u p t ; ~ C l e, ~ C l e a r ; ~ F l a, ~ F l a t, ~ R i p, ~}$ Rippled; Dis, Discontinuous. 'St, Slightly tacky; Stk, Sticky; NStk, Not Sticky; Spl, Slightly plastic; Npl, Not plastic.

In P3-RL, an A horizon was found on a $\mathrm{Cr}$ layer, with lithic contact less than $50 \mathrm{~cm}$ deep (Table 1). This profile is located in a landscape position typically erosional, which prevents the formation of deeper soils. The A horizon had a dominance of very dark gray color (7.5YR 3/1) with a weak structure. The $\mathrm{Cr}$ layer consists of angular and subangular rock boulders, accounting for more than $90 \%$ of the volume of its mass, with the remaining part filled with a weathered material (A horizon). The current climate condition may promote higher advances in soil formation in the long term. Other factors, such as organisms and relief, do not give conditions to potentiate the use of these soils for food production.

The soil P4-RQ presented sequence of horizons A1-A2-C1-C2 with a depth higher than $2.0 \mathrm{~m}$ (Table 1). This profile is located in the foothill position on the slope. All horizons have colors predominantly with a hue of $5 \mathrm{YR}$. Because of the high sand content, it presented weak aggregates with structure in subangular blocks and the humid and wet consistency were very friable and not sticky, respectively. Due to the poor performance of the pedogenetic processes 
of soil formation, the characteristics of this profile are closely related to the parent material, predominantly composed of sandstone.

\subsection{Physical Attributes}

The soil P1-RY presented an erratic distribution of clay, silt, and sand content. This lack of uniformity may result from the variation in the sedimentary nature of the parent material (Table 2). Due to the formation by sedimentation of fluvial nature, the occurrence of irregularity in the granulometric contents along the profile is a characteristic of this soil class (Buol et al., 2011). The observed sand contents were higher than $741 \mathrm{~g} \mathrm{~kg}^{-1}$, occurring in most horizons and composed of a higher proportion of fine sand.

Table 2. Physical characterization of the horizons of the studied profiles.

\begin{tabular}{|c|c|c|c|c|c|c|c|c|c|c|c|c|}
\hline \multirow[t]{2}{*}{ Horizon } & \multirow{2}{*}{$\begin{array}{l}\text { Depth } \\
\text { (m) }\end{array}$} & $\mathrm{VCS}^{\mathrm{a}}$ & $\mathrm{CS}$ & MS & FS & VFS & $\mathrm{TS}$ & $\begin{array}{c}\text { Clay } \\
\left(\mathrm{H}_{2} \mathrm{O}\right)\end{array}$ & $\begin{array}{c}\text { Clay } \\
(\mathrm{NaOH})\end{array}$ & Silt & $\begin{array}{c}\text { Flocculation } \\
\%\end{array}$ & \multirow[t]{2}{*}{$\begin{array}{c}\text { Textural } \\
\text { class }^{\mathrm{b}}\end{array}$} \\
\hline & & \multicolumn{10}{|c|}{$\mathrm{g} \mathrm{kg}^{-1}$} & \\
\hline \multicolumn{13}{|c|}{ P1-RY } \\
\hline $\mathrm{A}$ & $0-0.15$ & 13 & 14 & 52 & 410 & 252 & 741 & 51 & 204 & 55 & 75 & SCL \\
\hline $2 \mathrm{C} 1$ & $0.15-0.35$ & 0 & 1 & 57 & 671 & 236 & 965 & 25 & 25 & 10 & 0 & FSA \\
\hline $3 \mathrm{C} 2$ & $0.35-0.45$ & 0 & 1 & 135 & 728 & 90 & 954 & 25 & 25 & 21 & 0 & FS \\
\hline $4 \mathrm{C} 3$ & $0.45-0.80$ & 1 & 3 & 35 & 511 & 312 & 862 & 25 & 100 & 38 & 75 & LFS \\
\hline $5 \mathrm{C} 4$ & $0.80-1.10$ & 6 & 24 & 49 & 135 & 259 & 810 & 25 & 153 & 37 & 84 & LFS \\
\hline $6 \mathrm{C} 5$ & $1.10-1.30$ & 30 & 216 & 375 & 195 & 98 & 914 & 25 & 75 & 11 & 67 & FSA \\
\hline $7 \mathrm{C} 6$ & $1.30-1.40$ & 5 & 47 & 105 & 271 & 296 & 724 & 25 & 101 & 15 & 75 & SCL \\
\hline $8 \mathrm{C} 7$ & $1.40-1.60$ & 0 & 3 & 12 & 477 & 436 & 928 & 25 & 50 & 22 & 50 & FS \\
\hline $9 \mathrm{C} 8$ & $1.60-2.00^{+}$ & 1 & 21 & 327 & 424 & 177 & 950 & 25 & 25 & 25 & 0 & FS \\
\hline \multicolumn{13}{|c|}{ P2-PA } \\
\hline $\mathrm{A}$ & $0-0.20$ & 4 & 43 & 278 & 480 & 79 & 884 & 25 & 101 & 15 & 75 & LFS \\
\hline $\mathrm{AB}$ & $0.20-0.35$ & 2 & 36 & 241 & 492 & 108 & 879 & 25 & 100 & 21 & 75 & LFS \\
\hline BA & $0.35-0.60$ & 1 & 31 & 223 & 478 & 67 & 800 & 0 & 176 & 25 & 100 & FSL \\
\hline Bt1 & $0.60-1.10$ & 2 & 36 & 223 & 398 & 99 & 758 & 0 & 226 & 16 & 100 & SCL \\
\hline Bt2 & $1.10-2.10$ & 1 & 36 & 213 & 373 & 90 & 713 & 0 & 251 & 35 & 100 & SCL \\
\hline \multicolumn{13}{|c|}{ P3-RL } \\
\hline $\mathrm{A}$ & $0-0.10$ & 15 & 41 & 179 & 366 & 140 & 741 & 126 & 202 & 58 & 38 & SCL \\
\hline $\mathrm{CR}$ & $0.10-0.40$ & 18 & 48 & 210 & 313 & 163 & 752 & 100 & 190 & 58 & 38 & SCL \\
\hline \multicolumn{13}{|c|}{ P4-RQ } \\
\hline A1 & $0-0.20$ & 5 & 2 & 88 & 453 & 398 & 946 & 0 & 25 & 29 & 100 & FSA \\
\hline $\mathrm{A} 2$ & $0.20-0.55$ & 1 & 2 & 109 & 437 & 361 & 910 & 0 & 75 & 15 & 100 & FSA \\
\hline $\mathrm{C} 1$ & $0.55-1.13$ & 1 & 1 & 105 & 422 & 398 & 927 & 0 & 50 & 23 & 100 & FSA \\
\hline $\mathrm{C} 2$ & $1.13-2.00^{+}$ & 0 & 1 & 97 & 404 & 398 & 900 & 25 & 75 & 25 & 67 & FSA \\
\hline \multicolumn{13}{|c|}{ P5-PV } \\
\hline $\mathrm{A}$ & $0-0.10$ & 5 & 18 & 203 & 468 & 135 & 829 & 75 & 125 & 45 & 40 & LS \\
\hline BA & $0.10-0.20$ & 4 & 20 & 196 & 322 & 82 & 624 & 0 & 201 & 175 & 100 & SCL \\
\hline $\mathrm{Bt}$ & $0.20-0.85$ & 5 & 18 & 180 & 307 & 84 & 594 & 0 & 251 & 155 & 100 & SCL \\
\hline $\mathrm{BC}$ & $0.85-1.10$ & 6 & 18 & 177 & 312 & 109 & 622 & 0 & 226 & 152 & 100 & SCL \\
\hline $\mathrm{CR}$ & $1.10-1.30$ & 4 & 21 & 209 & 338 & 91 & 663 & 25 & 175 & 161 & 86 & SCL \\
\hline
\end{tabular}

${ }^{a}$ VCS, Very coarse sand; CS, Coarse sand; MS, Medium sand; FS, Fine sand; VFS, Very fine sand. ${ }^{b} S C L$, Sand clay loam; FSL, Fine sand loam; LFS, Loamy fine sand; FSA, Fine sand; LS, Loamy sand.

The P2-PA and P5-PV soil profiles showed highest clay concentration at the B horizons than A horizons, with texture ratio $\mathrm{B} / \mathrm{A}$ more than $1.8(\mathrm{P} 2-\mathrm{PA}=2.4, \mathrm{P} 5-\mathrm{PV}=2.0)$, but with a predominance of sand (Table 2). The soil P2-PA varied from 101 to $251 \mathrm{~g} \mathrm{~kg}^{-1}$ between A and Bt 2 horizons, whereas the soil P5-PV presented a variation in clay content between 125 and

Rev. Ambient. Água vol. 14 n. 4, e2355 - Taubaté 2019 
$251 \mathrm{~g} \mathrm{~kg}^{-1}$, the both in accordance with the criteria to classify it as a B textural, as observed by Santos et al. (2018).

Besides the difference of their position on the landscape, the soils P2-PA and P5-PV also had differences related to their parent material (i.e., sandstone). These differences may be responsible for granulometric variation and morphologic attributes showed in Table 1. However, both P2-PA and P5-PV showed flocculation equal to $100 \%$ at the Bt horizon that reflect the importance of the oxide content in the function of these soils.

In P4-RQ, the predominance of sand was significant in all horizons, with values ranging from 900 to $946 \mathrm{~g} \mathrm{~kg}^{-1}$, while the clay content was between 25 and $75 \mathrm{~g} \mathrm{~kg}^{-1}$. The parent material of this profile is characterized by sandstone and Cretaceous conglomerates, with a predominance of sandy sediments of continental, lacustrine, fluvial or wind deposition (Pfaltzgraff, 2010), which provided a higher amount of the sand fraction in this profile due to the little pedogenetic alteration.

\subsection{Chemical Attributes}

The values of $\mathrm{pH}$ in water of all profiles were higher in relation to the $\mathrm{pH}$ values in $\mathrm{KCl}$, indicating a predominance of a negative net load for all the studied profiles (Table 3 ). All profiles, except for some layers in P1-RY, had low $\mathrm{pH}$ values, probably due to the low amount of exchangeable bases in these soils. The distribution of $\mathrm{pH}$ values presented a low variation in the horizons of each profile, except for $\mathrm{P} 1-\mathrm{RY}$, presenting a $\mathrm{pH}$ in $\mathrm{KCl}$ with values between 4.3 and 5.6. The chemical characteristics of each layer of P1-RY are closely related to the parent material characteristic of this soil class, which is formed by sediment transport and deposition.

A low variation in the $\mathrm{pH}$ values was also observed in the soil P2-PA, with slightly lower values in the surface horizons. The lower values in the surface are possibly associated with the masking of the positive surface charge and creation of a negative charge due to the presence of organic matter. In addition, the increase of $\mathrm{pH}$ in the subsurface horizons of soils may be associated with the presence of iron oxides and the adsorption of $\mathrm{H}^{+}$ions at the soil colloids (Buol et al., 2011). The $\mathrm{pH}$ values in $\mathrm{KCl}$ show a similar tendency in the profile, but with a unit lower than that of the $\mathrm{pH}$ in water, indicating a predominance of acid cations $\left(\mathrm{Al}^{3+}\right.$ and $\left.\mathrm{H}^{+}\right)$at exchange sites (Tawornpruek et al., 2006).

The contents of $\mathrm{P}$ are similar for most of the profile horizons, except for P1-RY and the A horizons of P3-RL, P4-RQ, and P5-PV. The soil P1-RY presented the highest values of the sum of exchangeable bases $\left(\mathrm{K}^{+}, \mathrm{Ca}^{2+}\right.$, and $\left.\mathrm{Mg}^{2+}\right)$, being predominantly composed of $\mathrm{Ca}^{2+}$ and $\mathrm{Mg}^{2+}$. However, the lowest values of the sum of exchangeable bases were observed in P4-RQ and P5$\mathrm{PV}$, which is related to an intense leaching of basic cations and favored by climate conditions and soil characteristics. In P2-PA, the value of SB varied from 0.6 to $0.7 \mathrm{cmol}_{\mathrm{c}} \mathrm{kg}^{-1}$, with the highest values in the subsurface horizons. The increase of SB in depth in this profile is possibly related to a higher clay content, which increases its adsorption potential by cations. The contents of $\mathrm{Ca}^{2+}$ were higher in comparison to $\mathrm{Mg}^{2+}$ in all horizons and its values increased in depth, as observed in $\mathrm{SB}$ values. The contents of $\mathrm{K}^{+}$were low in all horizons, with values close to zero.

The dystrophic character was observed in most of the studied profiles, except for P1-RY, which showed a base saturation higher than $50 \%$ in the A horizon and in some of its layers. The low base saturation values observed in P2-PA, P3-RL, P4-RQ, and P5-PV reflect the low natural fertility of these soils. Regarding the $\mathrm{C}_{\text {org }}$ distribution, P1-RY presented an erratic distribution, while the other profiles showed higher values in the surface horizons, with decreases in depth. The same results were observed for the contents of $\mathrm{Al}^{3+}+\mathrm{H}^{+}$, which presented higher values in the surface horizons. According to Inda Junior et al. (2007), the formation of organometallic complexes with $\mathrm{Al}^{3+}$ increases the resistance of organic matter and minimizes the losses of $\mathrm{Al}^{3+}$.

\section{IPABH}

Rev. Ambient. Água vol. 14 n. 4, e2355 - Taubaté 2019 
Table 3. Chemical characterization of the studied profiles.

\begin{tabular}{|c|c|c|c|c|c|c|c|c|c|c|c|c|c|c|}
\hline Horizon & $\mathrm{H}_{2} \mathrm{O}^{p}$ & $\mathrm{KCl}$ & $\Delta \mathrm{pH}$ & $\begin{array}{c}\mathrm{P} \\
\mathrm{mg} \mathrm{kg}^{-1}\end{array}$ & $\mathrm{~K}^{+}$ & $\mathrm{Ca}^{2+}$ & $\begin{array}{c}\mathrm{Mg}^{2+} \\
\mathrm{mol}_{\mathrm{c}} \mathrm{kg}^{-1}\end{array}$ & $\mathrm{Al}^{3+}$ & SB & $\begin{array}{l}\mathrm{V} \\
(\%)\end{array}$ & $\mathrm{m}$ & $\begin{array}{c}\mathrm{C}_{\text {org }} \\
\mathrm{g} \mathrm{kg}^{-1}\end{array}$ & \multicolumn{2}{|c|}{$\begin{array}{c}\mathrm{H}+\mathrm{Al} \quad \mathrm{CEC} \\
\mathrm{cmol}_{\mathrm{c}} \mathrm{kg}^{-1}\end{array}$} \\
\hline \multicolumn{15}{|c|}{ P1-RY } \\
\hline A & 6.1 & 5.1 & -1.0 & 31.1 & 0.6 & 3.9 & 1.7 & 0.2 & 6.2 & 70 & 3 & 1.7 & 2.6 & 8.8 \\
\hline $2 \mathrm{C} 1$ & 6.2 & 4.5 & -1.7 & 19.7 & 0.1 & 0.7 & 0.3 & 0.2 & 1.1 & 44 & 15 & 0.6 & 1.4 & 2.5 \\
\hline $3 \mathrm{C} 3$ & 5.7 & 4.3 & -1.4 & 9.6 & 0.1 & 0.5 & 0.2 & 0.1 & 0.8 & 44 & 11 & 0.1 & 1.0 & 1.8 \\
\hline $4 \mathrm{C} 3$ & 6.1 & 4.4 & -1.7 & 29.1 & 0.2 & 1.2 & 0.7 & 0.1 & 2.1 & 57 & 5 & 1.2 & 1.6 & 3.7 \\
\hline $5 \mathrm{C} 4$ & 6.9 & 5.6 & -1.3 & 9.5 & 0.4 & 3.7 & 3.9 & 0.1 & 8.0 & 92 & 1 & 2.9 & 0.7 & 8.7 \\
\hline $6 \mathrm{C} 5$ & 7.2 & 5.2 & -2.0 & 13.1 & 0.1 & 0.8 & 1.2 & 0.1 & 2.1 & 81 & 5 & 0.1 & 0.5 & 2.6 \\
\hline 7C6 & 6.2 & 5.0 & -1.2 & 5.5 & 0.2 & 1.1 & 2.0 & 0.1 & 3.3 & 79 & 3 & 0.6 & 0.9 & 4.2 \\
\hline $8 \mathrm{C7}$ & 6.7 & 5.0 & -1.7 & 4.0 & 0.1 & 0.7 & 1.0 & 0.1 & 1.8 & 82 & 5 & 0.1 & 0.4 & 2.2 \\
\hline $9 \mathrm{C} 8$ & 6.6 & 5.1 & -1.5 & 3.2 & 0.1 & 0.4 & 0.1 & 0.2 & 0.6 & 55 & 25 & 0.1 & 0.6 & 1.1 \\
\hline \multicolumn{15}{|c|}{ P2-PA } \\
\hline A & 4.6 & 3.6 & -1.0 & 1.7 & 0.1 & 0.4 & 0.1 & 0.1 & 0.6 & 15 & 14 & 5.2 & 3.5 & 3.9 \\
\hline $\mathrm{AB}$ & 4.7 & 3.8 & -0.9 & 1.7 & 0.1 & 0.4 & 0.1 & 0.6 & 0.6 & 23 & 50 & 2.3 & 2.2 & 2.6 \\
\hline BA & 4.9 & 3.8 & -1.1 & 1.7 & 0.1 & 0.4 & 0.1 & 0.5 & 0.6 & 28 & 45 & 2.3 & 1.7 & 2.1 \\
\hline Bt1 & 4.9 & 3.9 & -1.0 & 1.7 & 0.1 & 0.5 & 0.1 & 0.5 & 0.7 & 33 & 42 & 1.7 & 1.6 & 2.1 \\
\hline $\mathrm{Bt} 2$ & 5.1 & 4.0 & -1.1 & 1.7 & 0.1 & 0.5 & 0.1 & 0.3 & 0.7 & 39 & 30 & 0.6 & 1.3 & 1.8 \\
\hline \multicolumn{15}{|c|}{ P3-RL } \\
\hline A & 4.2 & 3.5 & -0.7 & 4.0 & 0.1 & 0.1 & 0.1 & 1.1 & 0.3 & 7 & 79 & 10.5 & 4.1 & 4.4 \\
\hline CR & 4.9 & 3.9 & -1.0 & 1.4 & 0.1 & 0.2 & 0.2 & 0.2 & 0.5 & 31 & 29 & 4.2 & 1.3 & 1.6 \\
\hline \multicolumn{15}{|c|}{ P4-RQ } \\
\hline A1 & 5.3 & 3.9 & -1.4 & 2.0 & 0.1 & 0.1 & 0.1 & 0.5 & 0.3 & 17 & 63 & 2.9 & 1.7 & 1.8 \\
\hline A2 & 5.6 & 4.2 & -1.4 & 1.7 & 0.1 & 0.1 & 0.1 & 0.4 & 0.3 & 18 & 57 & 1.2 & 1.7 & 1.7 \\
\hline $\mathrm{C} 1$ & 5.0 & 4.0 & -1.0 & 1.7 & 0.1 & 0.1 & 0.1 & 0.4 & 0.3 & 17 & 57 & 1.2 & 1.8 & 1.8 \\
\hline $\mathrm{C} 2$ & 5.0 & 4.0 & -1.0 & 1.7 & 0.1 & 0.1 & 0.1 & 0.4 & 0.3 & 19 & 57 & 0.1 & 1.6 & 1.6 \\
\hline \multicolumn{15}{|c|}{ P5-PV } \\
\hline A & 4.1 & 3.4 & -0.8 & 3.0 & 0.1 & 0.1 & 0.1 & 0.8 & 0.3 & 9 & 73 & 7.6 & 3.1 & 3.3 \\
\hline BA & 4.4 & 3.5 & -0.8 & 1.7 & 0.1 & 0.1 & 0.1 & 0.9 & 0.3 & 20 & 75 & 1.2 & 1.5 & 1.5 \\
\hline $\mathrm{Bi}$ & 3.6 & 3.3 & -0.3 & 1.7 & 0.1 & 0.1 & 0.1 & 1.1 & 0.3 & 13 & 79 & 1.2 & 2.3 & 2.3 \\
\hline BC & 3.6 & 3.2 & -0.4 & 1.7 & 0.1 & 0.1 & 0.1 & 1.0 & 0.3 & 14 & 77 & 1.2 & 2.2 & 2.2 \\
\hline CR & 3.8 & 3.2 & -0.6 & 1.7 & 0.1 & 0.1 & 0.1 & 0.8 & 0.3 & 33 & 73 & 1.2 & 0.9 & 0.9 \\
\hline
\end{tabular}

The highest CEC values were 8.8 and $8.7 \mathrm{cmol}_{\mathrm{c}} \mathrm{kg}^{-1}$ for the A horizon and layer $5 \mathrm{C} 4$ in P1-RY, respectively. Other studied soils showed CEC decrease with depth, as well as $\mathrm{C}_{\text {org }}$ content. This scenario can be related to the low clay content in these soils, as well as the probable predominance of minerals containing a small amount of permanent charge such as kaolinite, which provide high dependence of organic matter in the CEC. Tawornpruek et al. (2006) also observed a relationship between CEC variations in depth with soil organic carbon content.

\subsection{Sulfuric attack, weathering indexes and crystallinity of iron oxides}

In the clay fraction of the studied soils, the $\mathrm{SiO}_{2}$ was the oxide of highest concentration (3.2 to $8.9 \%$ ), followed by $\mathrm{Al}_{2} \mathrm{O}_{3}$ (1.5 to $8.5 \%$ ), $\mathrm{Fe}_{2} \mathrm{O}_{3}(0.4$ to $3.2 \%)$ and $\mathrm{TiO}_{3}(0.2$ to $0.9 \%$ ) (Table 4). This behavior suggests a majority presence of phyllosilicates in this fraction (Buol et al., 2011). The soils P2-PA and P5-PV presented the highest mean $\mathrm{SiO}_{2}$ content, which is reflection of the content of the clay fraction in these soils. The behavior observed for $\mathrm{Al}_{2} \mathrm{O}_{3}$, and $\mathrm{Fe}_{2} \mathrm{O}_{3}$ suggests high content of aluminum octahedrons and iron oxides such as goethite and hematite, respectively. 
Table 4. Oxides rates by sulfuric attack, weathering indices and crystalline and amorphous Fe.

\begin{tabular}{|c|c|c|c|c|c|c|c|c|c|}
\hline Horizon & $\mathrm{SiO}_{2}$ & $\mathrm{Al}_{2} \mathrm{O}_{3}$ & $\mathrm{TiO}_{3}$ & $\mathrm{Fe}_{2} \mathrm{O}_{3}$ & $\mathrm{Ki}$ & $\mathrm{Kr}$ & $\mathrm{Fe}_{\mathrm{d}} \mathrm{g} \mathrm{kg}^{-1}$ & $\mathrm{Fe}_{\mathrm{o}}$ & $\mathrm{Fe}_{\mathrm{o}} / \mathrm{F}_{\mathrm{d}}$ \\
\hline \multicolumn{10}{|c|}{$\mathrm{P} 1-\mathrm{RY}$} \\
\hline A & 6.4 & 3.3 & 0.5 & 1.4 & 3.3 & 2.6 & 0.9 & 0.5 & 0.6 \\
\hline \multicolumn{10}{|c|}{$\mathrm{P} 2-\mathrm{PA}$} \\
\hline A & 6.1 & 4.2 & 0.6 & 3.0 & 2.5 & 1.7 & 1.9 & 0.3 & 0.2 \\
\hline Bt1 & 8.9 & 8.5 & 0.9 & 3.2 & 1.8 & 1.4 & 1.5 & 0.2 & 0.1 \\
\hline \multicolumn{10}{|c|}{$\mathrm{P} 3-\mathrm{RL}$} \\
\hline A & 7.7 & 6.7 & 0.3 & 0.9 & 2.0 & 1.8 & 1.0 & 0.2 & 0.2 \\
\hline \multicolumn{10}{|c|}{ P4 - RQ } \\
\hline A1 & 3.2 & 1.5 & 0.2 & 0.4 & 3.6 & 3.1 & 0.6 & 0.2 & 0.3 \\
\hline \multicolumn{10}{|c|}{$\mathrm{P} 5-\mathrm{PV}$} \\
\hline A & 9.8 & 6.7 & 0.4 & 1.7 & 2.5 & 2.1 & 1.8 & 0.1 & 0.1 \\
\hline $\mathrm{Bt}$ & 8.7 & 8.0 & 0.5 & 1.6 & 1.8 & 1.6 & 1.0 & 0.1 & 0.1 \\
\hline
\end{tabular}

The P1-RY and P4-RQ soil profiles presented the highest Ki values (Table 4). The P2-PA, P3-RL and P5-PV showed Ki values between 1.6 and 2.5 (Table 4). According Kehrig (1949), as kaolinite has a $\mathrm{Ki}$ value of 2.0, soils with a $\mathrm{Ki}$ value near 2.0 are kaolinitcs. Whereas values much higher than 2.0 are considered slightly weathered and values much smaller than 2.0 are considered strongly weathered. Thus, it is possible to affirm that the soils derived from sandstone in the Cerrado of the Piauí State are newly evolved, and soils derived from sandstones of the Piauí Formation (P2-PA, P3-RL and P5-PV) are more evolved.

While the Ki value of the soil P3-RL suggests a majority presence of kaolinite, this is a soil with many characteristics of a newly evolved soil, such as a deep horizon and the absence of the subsurface diagnostic horizons (Table 1). In addition, many of the Neossolos (Psamments) characteristics are provided directly from parent material, with smaller expression of the chemical weathering and neogenesis (Buol et al., 2011). This suggests that part of these came directly from sandstones of the Canindé Group, given that is possible to notice the presence of kaolinite in sandstone (Shelton, 1964).

All soils presented $\mathrm{Kr}$ values higher than 0.75 (Table 4), suggesting that all of them have more kaolinite than oxides (Kehrig, 1949). The soils P2-PA, P3-RL and P5-PV showed Fe expressively higher than other soils, which also suggests higher content of iron oxides such as hematite, goethite, lepidocrocite or maghemite (Buol et al., 2011). The Fe $\mathrm{d}_{\mathrm{d}}$ values of the P3-RL reinforce the thesis that its mineralogical compound might be partially provided by parent material. Wu and Caetano-Chang (1992) reported that sandstone can provide lithological iron oxides improving cementation of sandstone. The Feo values are low for these soils ( 0.1 to 0.5$)$, indicating a low occurrence of ferrihydrite and Fe from organic compounds in these soils (Buol et al., 2011). The $\mathrm{Fe}_{\mathrm{o}} / \mathrm{Fe}_{\mathrm{d}}$ ratio, except for $\mathrm{P} 1-\mathrm{RY}$ that have influence of fluvial sediments, show that studied soils have high content of crystalline iron oxyhydroxides, given that their values are close to 0 (0.1 to 0.3) (Buol et al., 2011). This is a reflection of the pedogenical or lithological environment conditions with good drainage and aeration during the formation of these iron oxides, different from the soil P1-PY, which is influenced by river flooding annually.

\section{CONCLUSIONS}

The relief and the parent material are the most important soil-forming factors of Cerrado 
of the Piauí State, Brazil. The relief is determinant in the thickness and horizon depth. In addition, river flooding has strong influences in soil on the floodplain, providing distinct characteristics. Sandstone is responsible for some pedogenetic standards in these soils, including the high sand content, as well as the low content of bases saturation and clay, which make the soils for this region extremely dependent on organic matter when it comes to soil charges. The soils from this region are young according to the weathering indexes. However, the sandstones from Canindé Group apparently are providing lithological secondary minerals for the soil.

\section{ACKNOWLEDGEMENTS}

This research project was supported by the Programa de Pós-Graduação em Ciências Agrárias of the Universidade Federal do Piauí (PPGCA/UFPI) that provided the necessary infrastructure, and the Coordination of Improvement of Higher Level Personnel (CAPES) that provided scholarship to the first author in the social demand modality.

\section{REFERENCES}

BUOL, S. W.; SOUTHARD, R. J.; GRAHAM, R. C.; McDANIEL, P. A. Soil Genesis and Classification. $6^{\text {th }}$ ed. New Jersey: John Wiley \& Sons, 2011. 543 p.

CAMARGO, O. A.; MONIZ, A. C.; JORGE, J. A.; VALADARES, J. M. A. S. Métodos de análise química, mineralógica e física de solos do IAC. Instituto Agronômico de Campinas. Boletim Técnico IAC, n. 106, p. 77, 2009.

DEMATTÊ, J. A.; MElO BORTOLETTO, M. A.; VASQUES, G. M.; RIZZO, R. Quantificação de matéria orgânica do solo através de modelos matemáticos utilizando colorimetria no sistema Munsell de cores. Bragantia, v. 70, n. 3, p. 590-597, 2011. https://dx.doi.org/10.1590/S0006-87052011005000006

INDA JUNIOR, A. V.; BAYER, C.; CONCEIÇÃO, P. C.; BOEN, M.; SALTON, J. C.; TONIN, A. T. Variáveis relacionadas à estabilidade de complexos organominerais em solos tropicais e subtropicais brasileiros. Ciência Rural, Santa Maria, v. 37, n. 5, p. 1301-1307, 2007. https://dx.doi.org/10.1590/S0103-84782007000500013

INMET; BDMEP. Website. 2017. Disponível em: http://www.inmet.gov.br/portal/. Acesso em: 20 jan. 2018.

KEHRIG, A. G. As relações Ki e Kr no solo. Rio de Janeiro: Instituto de Química Agrícola, 1949. 52 p. (IQA. Boletim técnico, 12).

MEHRA, O. P.; JACKSON, M. L. Iron oxide removal from soils and clay by a dithionite-citrate system buffered with sodium bicarbonate. Clays and Clay Minerals, v. 7, p. 317-327, 1960. https://doi.org/10.1016/B978-0-08-009235-5.50026-7

PFALTZGRAFF, P. Geodiversidade do estado do Piaui. Programa Geologia do Brasil levantamento da Geodiversidade. In: PFALTZGRAFF, P.; TORRES, F.; BRANDÃO, R. Serviço Geológico do Brasil. Recife: CPRM, 2010. 260 p.

PRAGANA, B. R.; RIBEIRO, R. M.; NÓBREGA, A. J. C.; RIBEIRO FILHO, R. M.; COSTA, A. J. Qualidade física de Latossolos Amarelos sob plantio direto na região do Cerrado piauiense. Revista Brasileira de Ciência do Solo, v. 36, n. 5, p. 1591-1600, 2012. https://dx.doi.org/10.1590/S0100-06832012000500023 
RAIJ, B. V.; ANDRADE, J. C.; CANTARELLA, H.; QUAGGIO, J. A. Análise química para avaliação da fertilidade de solos tropicais. Campinas: IAC, 2001. 285p.

SANTOS, H. G.; JACOMINE, P. K. T.; ANJOS, L. H. C.; OLIVEIRA, V. A.; LUMBRELAS, J. F.; COELHO, M. R.; ALMEIDA, J. A.; ARAUJO FILHO, J. C.; OLIVEIRA, J. B.; CUNHA, T. J. F. Sistema Brasileiro de Classificação de Solos. 5. ed. revisada e ampliada - Brasília, DF: Embrapa, 2018.

SANTOS, R. D.; SANTOS, H. G.; KER, J. C.; ANJOS, L. H. C.; SHIMIZU, S. H. Manual de descrição e coleta de solo no campo. 7. ed. Viçosa, MG: SBCS, 2015. 101p.

SCHWERTMANN, U. Use of oxalate for Fe extraction from soils. Canadian Journal of Soil Science, v. 53, n. 2, p. 244-246, 1973. https://dx.doi.org/10.4141/cjss73-037

SHELTON, J. W. Authigenic Kaolinite in sandstone. Journal of Sedimentary Petrology, v. 34, n. 1, p. 102-111, 1964. https://doi.org/10.1306/74D70FDD-2B21-11D7$8648000102 \mathrm{C} 1865 \mathrm{D}$

SILVA, M. B.; ANJOS, L. H. C.; PEREIRA, M. G.; SCHIAVO, J. A.; COOPER, M.; SOUZA CAVASSANI, R. Soils in the karst landscape of Bodoquena plateau in cerrado region of Brazil. Catena, v. 154, p. 107-117, 2017. https://dx.doi.org/10.1016/j.catena.2017.02.022

TAWORNPRUEK, S.; KHEORUENROMNE, I.; SUDDHIPRAKARN, A.; GILKES, R. J. Properties of red Oxisols on calcareous sedimentary rocks in Thailand. Geoderma, v. 136, n. 3-4, p. 477-493, 2006. https://dx.doir.org/10.1016/j.geoderma.2006.04.022

TEIXEIRA, P. C.; DONAGEMMA, G. K.; FONTANA, A.; TEIXEIRA, W. G. Manual de métodos de análise de solo. Rio de Janeiro. 4. ed. Brasília: EMBRAPA, 2017. 573 p.

WU, F. T.; CAETANO-CHANG, M. R. Estudo mineralógico dos arenitos das formações Pirambóia e Botucatu no Centro-Leste do Estado de São Paulo. Revista do Instituto Geológico, v. 13, n. 1, p. 58-68, 1992. http://dx.doi.org/10.5935/0100-929X.19920004 


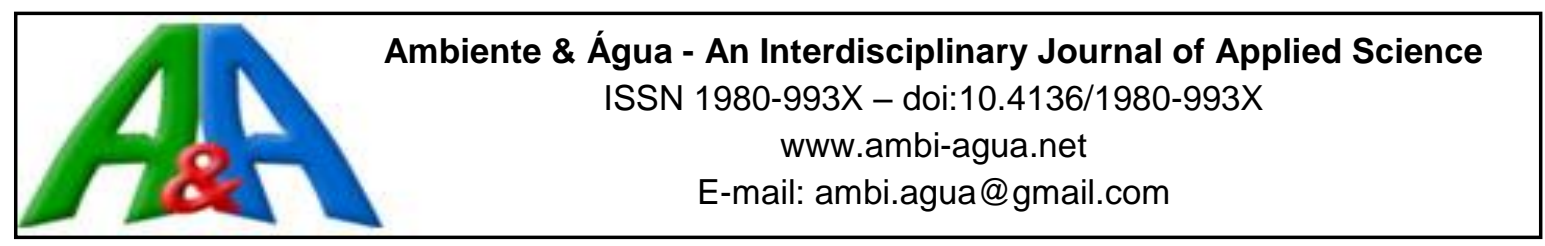

\title{
Deforestation impact on discharge regime in the Doce River Basin
}

\author{
ARTICLES doi:10.4136/ambi-agua.2370 \\ Received: 24 Jan. 2019; Accepted: 29 Apr. 2019 \\ Barbara Ucelis Lyra*iD; Daniel Rigo \\ Universidade Federal do Espírito Santo (UFES), Vitória, ES, Brasil \\ Departamento de Engenharia Ambiental. \\ E-mail: barbara.uceli@gmail.com,rigo@npd.ufes.br \\ "Corresponding author
}

\begin{abstract}
The construction of scenarios using hydrological models can evaluate the hydrological response in watersheds, due to changes in the soil use. In this context, this study analyzed the consequences of deforestation in the hydrological behavior of the Doce River Basin, which has a drainage area of approximately $86.715 \mathrm{~km}^{2}$. The basin presents problems regarding water availability, floods, indiscriminate deforestation and inadequate soil management. The Model of Large Basins (MGB-IPH) was selected, using daily data from 1990 to 2014, 11 fluviometric, 81 rainfall and 12 meteorological stations, numerical model of the land, soil maps, and use and land cover. Hydrological modeling was performed in the following steps: calibration of parameters (1990 and 2005), validation (2006 to 2014) and simulation of deforestation scenarios (2000 to 2014). It was observed that the replacement of forests by pasture caused reductions in the average annual flows, indicating a decrease in average flows in deforestation scenarios. As for the behavior of floods, deforestation caused them to increase, while the annual minimum flows reduced with deforestation. The results demonstrate the worsening that the simulated scenarios can cause in the problems already found in the basin, such as floods and water shortages, to supply the uses for which the basin is intended.
\end{abstract}

Keywords: deforestation, Doce river basin, hydrological simulation.

\section{Impacto do desmatamento no regime de vazões da bacia hidrográfica do rio Doce}

\section{RESUMO}

A resposta hidrológica em bacias hidrográficas devido às mudanças do uso do solo pode ser avaliada por meio da construção de cenários, usando modelos hidrológicos. Nesse contexto, o objetivo desse trabalho foi analisar as consequências do desmatamento no comportamento hidrológico da bacia hidrográfica do rio Doce, que possui uma área de drenagem de $86.715 \mathrm{~km}^{2}$. Alguns dos problemas enfrentados pela bacia estão relacionados à disponibilidade hídrica, inundações, desmatamento indiscriminado e manejo inadequado do solo. Sendo assim, foi selecionado o Modelo de Grandes Bacias (MGB-IPH), onde foram usados dados diários de 11 postos fluviométricos, 81 pluviométricos e 12 meteorológicos, modelo numérico do terreno, mapas de solos e uso e cobertura do solo (2000). A modelagem hidrológica foi realizada nas seguintes etapas: calibração dos parâmetros (1990 a 2005), validação (2006 a 2014) e simulação dos cenários de desmatamento (2000 a 2014). Foi constatado que a substituição de florestas por 
pastagens provocou reduções nas vazões médias anuais, indicando uma diminuição das vazões médias em cenários de desmatamento. Quanto ao comportamento das cheias, o desmatamento provocou o aumento das mesmas, enquanto que às vazões mínimas anuais reduziram com o desmatamento. Os resultados demonstram os agravamentos que os cenários simulados podem acarretar nos problemas já encontrados na bacia como inundações e escassez de água para suprimento dos usos para os quais a bacia se destina.

Palavras-chave: bacia do rio Doce, desmatamento, simulação hidrológica.

\section{INTRODUCTION}

Anthropogenic activities, such as high standards of living, demographic changes and intense land and water consumptions are pressuring natural resources, undermining sustainability and thereby environmental issues. Pressure on water resources at local, regional and national scales for human consumption, irrigation, energy production, and industrial uses, among others, are steadily increasing. All these pressures imposed on the soil-vegetation-water system impact the hydrological cycle, generating uncertainties in the sustainable maintenance of water resources in watersheds.

Due to difficulties in monitoring and data scarcity, water discharge in a river basin can not be constantly monitored. Thus, the impact of anthropic activity on hydrological variables in watersheds can be evaluated in qualitative and quantitative terms through the construction of scenarios by means of mathematical and physical models associated with geographic information systems (Prado, 2005). As a part of mathematical models, hydrological modeling emerges as a worldwide tool used for several applications, such as the analysis of hydrological response due to changes in land use and occupation (Abbaspour et al., 2015).

The Large Basin Model (MGB-IPH) is a hydrological model that has been applied to determine the impacts of changes in land use on the hydrological regime in different types of climate and vegetation. Caram (2010), Bayer (2014) and Beserra (2016) conducted studies on the impacts of changes in land use in watersheds using MGB-IPH.

Land-use change processes encompass natural vegetation removal or degradation, both associated with significant ecological impacts on practically all scales. Globally, they contribute to greenhouse gas emissions that are associated with global climate change, while regionally and locally, they affect hydrological responses in the watershed (Ibarra-Montoya et al., 2011).

The Doce River Watershed is an example of a basin that has issues related to indiscriminate natural vegetal removal and inadequate soil management. Consequently, the area constantly experiences extreme events (floods and droughts) and water availability and quality issues. This paper therefore estimated flow variations in the Doce River Basin over different deforestation scenarios, using the MGB-IPH.

\section{METHODOLOGY}

\subsection{Study Area}

The Doce River Watershed is located in the Southeast region of Brazil, covering part of states of Minas Gerais and Espírito Santo. The basin has a drainage area of approximately $86.715 \mathrm{~km}^{2}$, of which $86 \%$ belongs to the State of Minas Gerais and the remaining $14 \%$ to the State of Espírito Santo (CBH-DOCE et al., 2006). The main headwaters are located in the state of Minas Gerais, in the Mantiqueira and Espinhaço hills, and its water runs about $850 \mathrm{~km}$ until reaching the Atlantic Ocean, in the state of Espírito Santo (PIRH- DOCE, 2010).

Cupolillo et al. (2008) state that the predominant climate in the basin is classified as humid tropical. The rainy season starts in November and lasts until May with annual precipitation 
exceeding $700 \mathrm{~mm}$. Most of the entire basin has high average annual temperatures (above $18^{\circ} \mathrm{C}$ ) during most of the year, even during winter. In general, the river water level follows the rainfall, characterized as perennial. The higher flows occur in the months of December, January, and March, while the lowers occur in August and September (PIRHDOCE, 2010).

According to PIRH-DOCE (2010), in the Doce River Watershed, the higher specific flows, which mean the water flow per extension of an area, are not directly associated with the larger drainage areas, but with soil type and rainfall periodicity. The basins that are located closer to the headwaters present a higher water production than those in the state of Espírito Santo, indicating a diversity of water availability, which may require different actions for each specific sub-basin.

Floods, which are a major problem in the Doce River Basin, are mainly recorded in the months between December and February. In addition to the intense rainfall that causes flooding, since the begging of the 19th century, the Doce River Basin had its natural vegetation cover (Atlantic forest) removed due to the planting of coffee and sugarcane crops, logging and pasture formation. These actions modify soil infiltration and storage capacity, aggravating the effects of floods, especially in small basins. Along with to this, the disordered occupation of the floodplain areas, especially in urban areas, has aggravated the damages caused by floods (PIRH-DOCE, 2010).

\subsection{MGB-IPH Model}

The Large Basin Model (MGB-IPH), developed by Collischonn (2001), is a large-scale distributed hydrologic model that performs flow propagation using the Muskingum-Cunge method. The model uses conceptual and physical equations to simulate the terrestrial hydrological cycle: soil water balance; energy balance; evapotranspiration, interception, flow generation (surface, subsurface, and base flow); and flow propagation. In the present study, the MGB-IPH, Version 3.0, was used, which considers a discretization of the basin in irregular units (mini-basins) and Hydrologic Response Units (HRU's), both using the Digital Elevation Model (MDE), land-use map and according to similarity in hydrological behavior (Fan and Collischonn, 2014). The vertical water and energy balances are computed independently for each HRU in each mini basin. The balance is performed considering only one layer of soil, according to Equation 1:

$\frac{d W}{d t}=P-E T-D_{\text {sup }}-D_{\text {int }}-D_{b a s}+D_{c a p}$

Where: $W(\mathrm{~mm})$ is the water storage in the soil layer, $P\left(\mathrm{~mm} \mathrm{dt}^{-1}\right)$ is rain that reaches the ground, ET $\left(\mathrm{mm} \mathrm{dt}^{-1}\right)$ is the evapotranspiration, Dsup $\left(\mathrm{mm} \mathrm{dt}^{-1}\right)$ is the surface runoff, Dint (mm $\left.\mathrm{dt}^{-1}\right)$ is the subsurface runoff, Dbas $\left(\mathrm{mm} \mathrm{dt}^{-1}\right)$ is the percolation to the water table, and Dcap $\left(\mathrm{mm} \mathrm{dt}^{-1}\right)$ is flow due capillary forces (Collischonn, 2001). The energy and evapotranspiration balance of soil and vegetation are estimated by the Penman-Monteith equation (Equation 2):

$E T=\left(\frac{\Delta \cdot A+\rho_{A} c_{p} \frac{D}{r_{a}}}{\Delta+\gamma\left(1+\frac{r_{s}}{r_{a}}\right)}\right) \frac{1}{l a m \cdot \rho_{w}}$

Where: $\lambda\left(\mathrm{MJ} \mathrm{kg}^{-1}\right)$ is the latent heat of vaporization, $\Delta\left(\mathrm{kPa}^{\circ} \mathrm{C}^{-1}\right)$ is the function of saturation vapor pressure gradients, $\mathrm{A}\left(\mathrm{MJ} \mathrm{m}^{-2} \mathrm{~s}^{-1}\right)$ is the available energy, $\rho_{\mathrm{a}}\left(\mathrm{kg} \mathrm{m}^{-3}\right)$ is the air density, $\rho_{\mathrm{w}}\left(\mathrm{kg} \mathrm{m}^{-3}\right)$ is the specific weight of water, $\mathrm{c}_{\mathrm{p}}\left(\mathrm{MJ} \mathrm{kg}^{-1}{ }^{\circ} \mathrm{C}^{-1}\right)$ is the specific heat of humid air, $\mathrm{D}(\mathrm{kPa})$ is the vapor pressure deficit, $\gamma\left(\mathrm{kPa}^{\circ} \mathrm{C}^{-1}\right)$ is the psychrometric constant, $\mathrm{rs}\left(\mathrm{s} \mathrm{m}^{-1}\right)$ is the surface resistance of the soil cover and $\mathrm{ra}\left(\mathrm{s} \mathrm{m}^{-1}\right)$ is the aerodynamic resistance (Collischonn, 2001). The model parameters that are important to discriminate soil land use and

\section{IPABH}

Rev. Ambient. Água vol. 14 n. 4, e2370 - Taubaté 2019 
coverings are: albedo $(\alpha)$, leaf area index (IAF), aerodynamic resistance (ra), surface resistance (rs) and the interception coefficient $(\alpha)$, in addition to the parameter $\mathrm{Wm}$, which determines the maximum storage in the soil and must be altered according to the land use and cover typologies (Collischonn, 2001).

The value of the albedo parameter defines the energy that is available for the evapotranspiration process. Deforestation tends to reduce evapotranspiration and increase runoff; thus, deforestation causes an increase in albedo (Collischonn, 2001). The albedo value was assigned from 0.12 to 0.16 for the forest and the albedo value from 0.18 to 0.24 for the pasture, which constitutes deforestation.

Regarding the IAF parameter, the higher the IAF, the greater the maximum interception blade, decreasing the flow. For the forest, the value was assigned from 4.0 to 9.0 and for the pasture, the value from 1.0 to 4.0.

The surface resistance represents the process of the flow of the water from the soil, through the interior of the plant, to the outside of the leaves, besides controlling the sweating process. The higher the surface resistance, the less sweating. In forests, the surface resistance is approximately $100 \mathrm{~s} / \mathrm{m}$ in pasture, approximately $70 \mathrm{~s} / \mathrm{m}$ (Shuttleworth, 1993).

As for the parameter of soil storage capacity, this is different for different vegetative cover, because the forests draw water from depths greater than the field vegetation, since the roots of the forest trees reach greater depths. This difference is fundamental in analyzing the hydrological consequences of land use change, especially during periods of drought, because while the volume of water available to the field vegetation is already depleted, the forest vegetation continues to perspire at a normal rate (Collischonn, 2001).

It is likely that parameter $b$ has a strong relation with infiltration capacity; however, it is not possible to directly estimate the values of $b$ based on the characteristics of the vegetative cover. Sensitivity analysis revealed that the higher the value of $b$, the larger the peaks of small and medium floods; however, $b$ does not profoundly alter the peaks of the highest floods. Basins with deforestation should be represented by the model with higher values of $b$ (Collischonn, 2001).

Both the maximum storage parameter $(\mathrm{Wm})$ and parameter $\mathrm{b}$ are used as calibration parameters of the MGB model.

\subsection{Input database}

The first database required for modeling in MGB-IPH is composed of slope, pedology and land use/cover. The slope data used comes from an SRTM (Shuttle Radar Topography Mission), produced by NASA (National Aeronautics and Space Administration), with a spatial resolution of 90 meters (CGIAR, 2017). For pedology, data was extracted from the Brazilian soil map (EMBRAPA, 2001) in the scale of 1:5,000,000. Finally, for land use and occupation data, a map available from the Brazilian Institute of Geography and Statistics (IBGE, 2000) was used, in a 1: 1,000,000 scale, corresponding to the calibration and validation periods. The agricultural class predominates in the basin, occupying $67.60 \%$, followed by the Atlantic forest class, covering $18.54 \%$.

The other data required for modeling refer to pluviometric, fluviometric and climatological variables. Data from 81 rainfall stations was used for these, and even though there were 60 fluviometric stations inside the basin, only 11 of them were used due to reliability. The historical series of these stations were taken from January 1, 1990, to December 31, 2014, and the data were publically available through the National Water Agency (ANA, 2017). The climatological data (temperature, relative air humidity, wind speed, atmospheric pressure and insolation) were made available by the National Institute of Meteorology (INMET, 2017), totaling 12 meteorological stations. Figure 1 shows the location of the river basin and the stations used.

Rev. Ambient. Água vol. 14 n. 4, e2370 - Taubaté 2019 


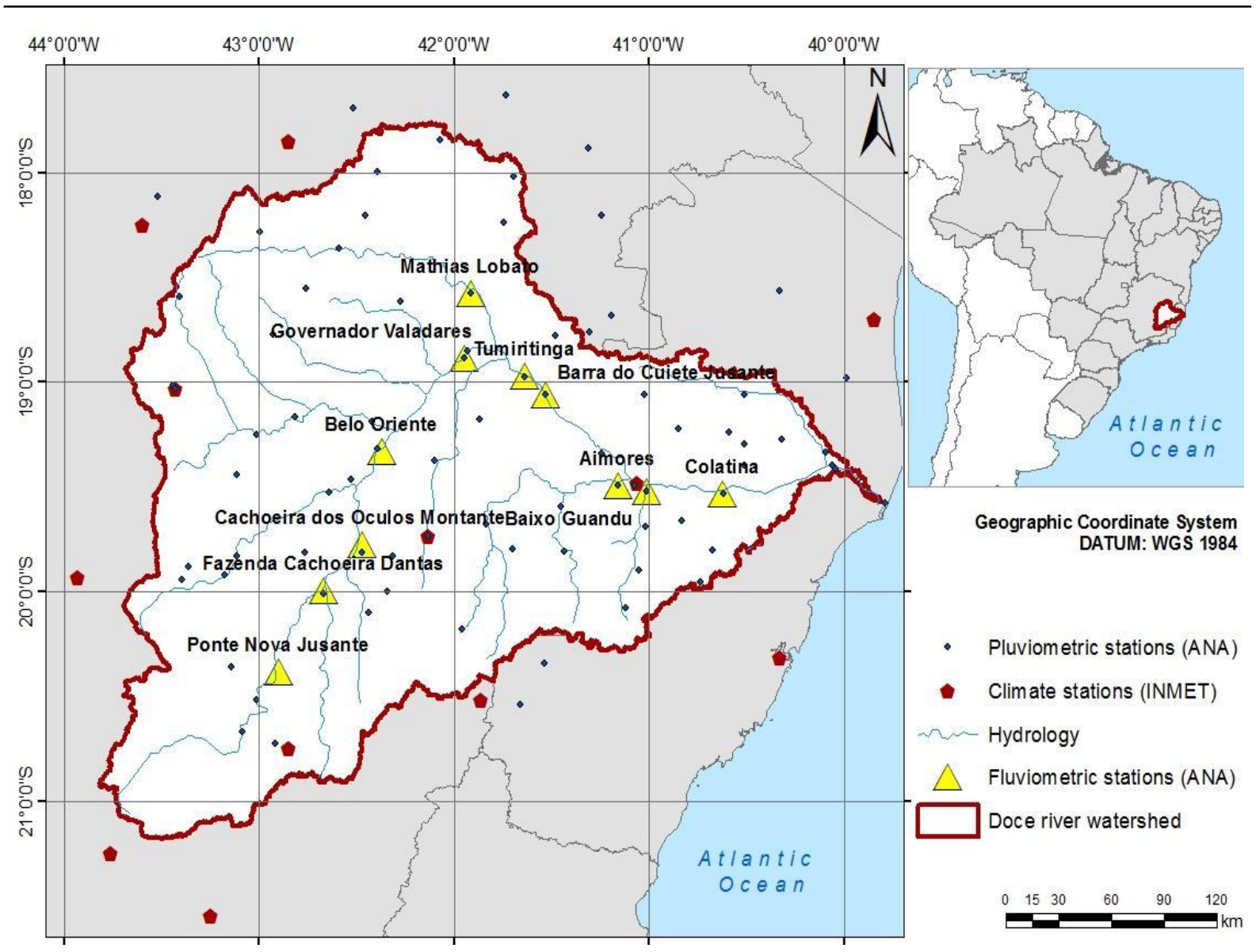

Figure 1. Location of the fluviometric, pluviometric and meteorological stations used in the simulation.

\subsection{Hydrological Modeling}

Hydrological simulation began with the spatial data discretization in ArcGIS. The drainage network was defined, and then divided into parts, which allowed the delimitation of the contributed areas for each part (mini-basins). The sub-basins were delimited according to the locations of the fluviometric stations and the basin outlet. As a result, 581 mini-basins and 12 sub-basins were identified.

Soil typologies were grouped in terms of two subjective classes of potential generation of runoff: 1) low potential or deep soils; 2) high potential or shallow soils. The first class comprises soils with low- and medium potential generation for runoff and high potential for water storage (latossoil and argissoil). The second class includes soils with high runoff generation capacity and low capacity for water storage (neosoil, gleysol, and cambisols). The final combination of reclassified soil types was used to generate HRU classes.

The land-use and cover map was also simplified by grouping some of its classes by hydrological similarity in order to facilitate analyses of the influence of vegetative change influence. For reclassification, the "Forest" class was considered to include natural vegetation (Atlantic forest), farm forestry and agroforestry. Similarly, natural and planted pastures were grouped into the "Pasture" class. With the simplified data, the 10 URHs were generated. Figure 2 shows the sub-basins and URHs created. 


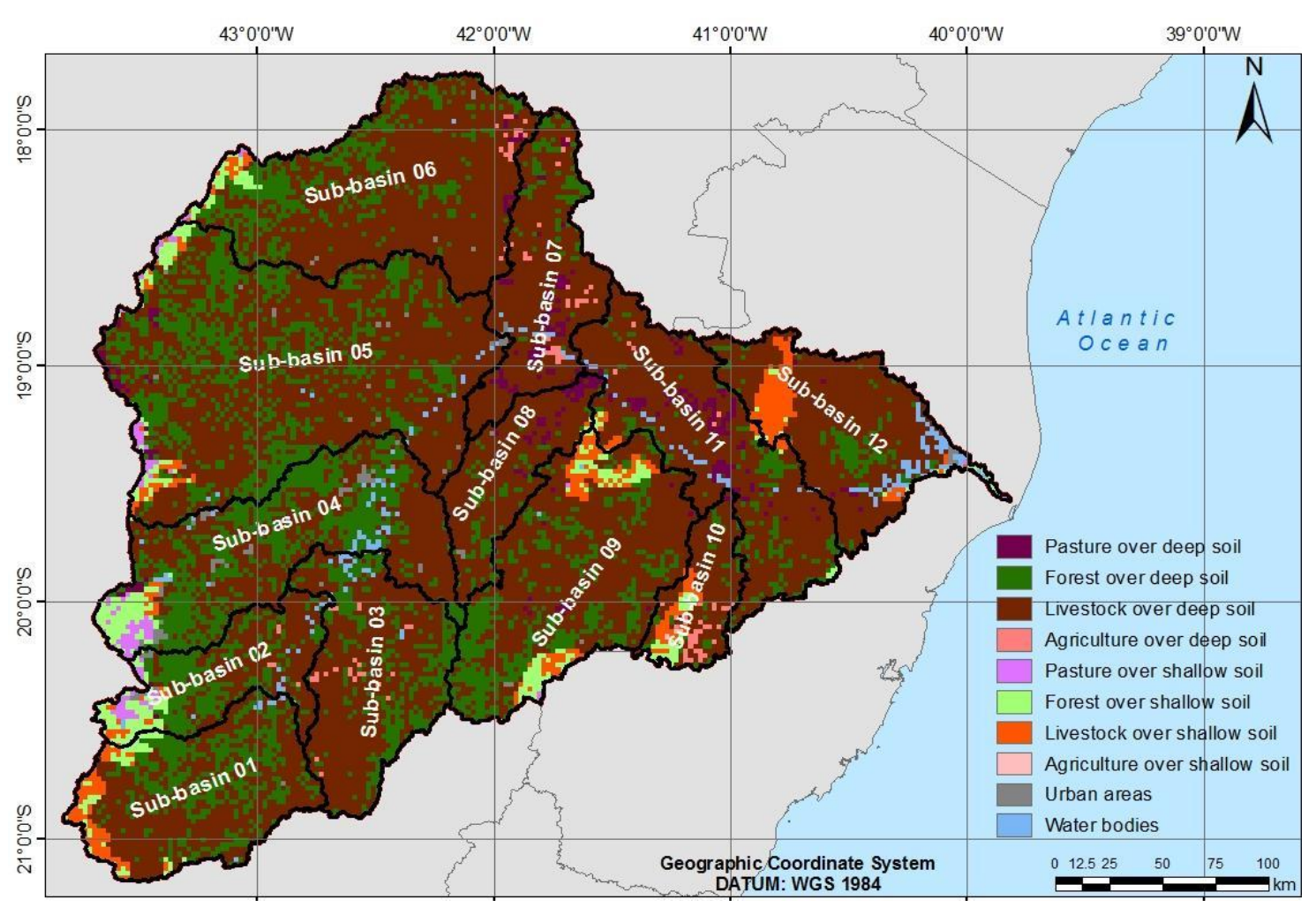

Figure 2. Sub-basins and HRUs created for the simulation in the MGB-IPH model.

Before the modeling, precipitation and flow data needed to be discretized according to the location of their pluviometric and fluviometric station location in the mini basin. Soon after, the climate data were prepared, in which the climatological averages and the daily climate files were generated. Vegetation data were also prepared, characterizing each HRU by the magnitude of albedo (a), leaf area index (LAI), canopy height (h) and surface resistance (Rs) parameters. The values adopted for each HRU were according to those cited by Collischonn (2001). It is important to mention that, for HRUs that had agricultural land uses, the vegetation parameters values were attributed by means of an arithmetic mean of the values of the parameters of the HRUs that contemplate the uses pasture and agriculture, as was done in the work of Collischonn (2001).

The model was manually calibrated with subsequent automatic calibration. The automatic calibration process occurred only for the sub-basins Number 01, 06 and 08, which obtained inferior performance after manual calibration. The results were compared visually from the hydrograms and flow permanence curves and from three performance metrics: the Nash and Sutcliffe efficiency coefficient (ENS), the $\mathrm{R}^{2}$ adjusted for the flow logarithm (ENSlog) and the relative error of the total volume of the hydrograms $(\Delta \mathrm{V})$. The calibration period used was from 1990 to 2005, while the validation step was the period from 2006 to 2014.

\subsection{Deforesting scenarios}

A major problem regarding land-use and occupation changes in the Doce River Basin lies in the replacement of the Atlantic Forest biome (natural landscape) into other uses. In order to evaluate the impact that land use and occupation has on the hydrological process, we estimate the discharge in 2000 using the MGB-IPH and compare with other five scenarios based on hypothetical levels of deforestation. The hydrological model considered scenarios where, initially, $100 \%$ of the basin was covered by forests. Simulations were then carried out using progressive stages of deforestation $(25 \%, 50 \%, 75 \%$, and $100 \%)$, with pasture in substitution for the existing forest. 
In order to analyze the effects of deforestation on the discharge, the simulation was repeated for each scenario considering the same historical period from 2000 to 2014, and climatological and precipitation data. Thus, the effects of the impacts of land-use changes on climate and precipitation were not considered in the paper. The values of the vegetation parameters adopted for the forest and pasture were the same as for calibration, while the soil parameters values were the ones found at the end of the automatic calibration.

\section{RESULTS AND DISCUSSION}

The calibration process considered 11 sub-basins, since there was no fluviometric station downstream from the sub-basin (11). Thus, the modeling results of sub-basin (11) were analyzed and not those of sub-basin (12). When comparing the results from the validation period with the calibration period, the results were slightly different for most of the stations, and the values estimated by the model showed good agreement with those monitored in the field, according to the performance metrics used. The flow estimations for all the scenarios proposed are presented numerically in Table 1 and graphically in Figure 3.

Table 1. Maximum, minimum and mean annual discharges per year and annual runoff difference compared to the actual situation in 2000, obtained for the period between 2000 and 2014 for sub-basin 11 .

\begin{tabular}{lcccccccc}
\hline SCENARIOS & $\begin{array}{c}\mathbf{Q}_{\text {Mean }} \\
\left(\mathrm{m}^{3} / \mathrm{s}\right)\end{array}$ & $\begin{array}{c}\Delta \mathbf{Q}_{\text {Mean }} \\
(\%)\end{array}$ & $\begin{array}{c}\mathbf{Q}_{\text {Max }} \\
\left(\mathrm{m}^{3} / \mathrm{s}\right)\end{array}$ & $\begin{array}{c}\Delta \mathbf{Q}_{\text {Max }} \\
(\%)\end{array}$ & $\begin{array}{c}\mathbf{Q}_{\text {Min }} \\
\left(\mathrm{m}^{3} / \mathrm{s}\right)\end{array}$ & $\begin{array}{c}\Delta \mathbf{Q}_{\text {Min }} \\
(\%)\end{array}$ & $\begin{array}{c}\mathbf{Q}_{\text {Med }} \\
(\mathrm{mm} / \mathrm{ano})\end{array}$ & $\begin{array}{c}\Delta \mathbf{Q} \\
(\%)\end{array}$ \\
\hline Actual simulation (year 2000) & 847,09 & - & 4495,97 & - & 316,41 & - & 3656,76 & - \\
0\% Past. and 100\% Flor. & 985,12 & 16,29 & 4055,55 & $-9,80$ & 483,28 & 52,74 & 4275,82 & 16,93 \\
25\% Past. and 75\% Flor. & 937,92 & 10,72 & 4124,24 & $-8,27$ & 430,43 & 36,04 & 4070,43 & $-4,80$ \\
50\% Past. and 50\% Flor. & 890,72 & 5,15 & 4198,59 & $-6,61$ & 377,57 & 19,33 & 3865,02 & $-5,05$ \\
75\% Past. and 25\% Flor. & 843,53 & $-0,42$ & 4274,67 & $-4,92$ & 324,67 & 2,61 & 3659,61 & $-5,31$ \\
100\% Past. and 0\% Flor. & 796,33 & $-5,99$ & 4353,98 & $-3,16$ & 271,74 & $-14,12$ & 3454,22 & $-5,61$ \\
\hline
\end{tabular}

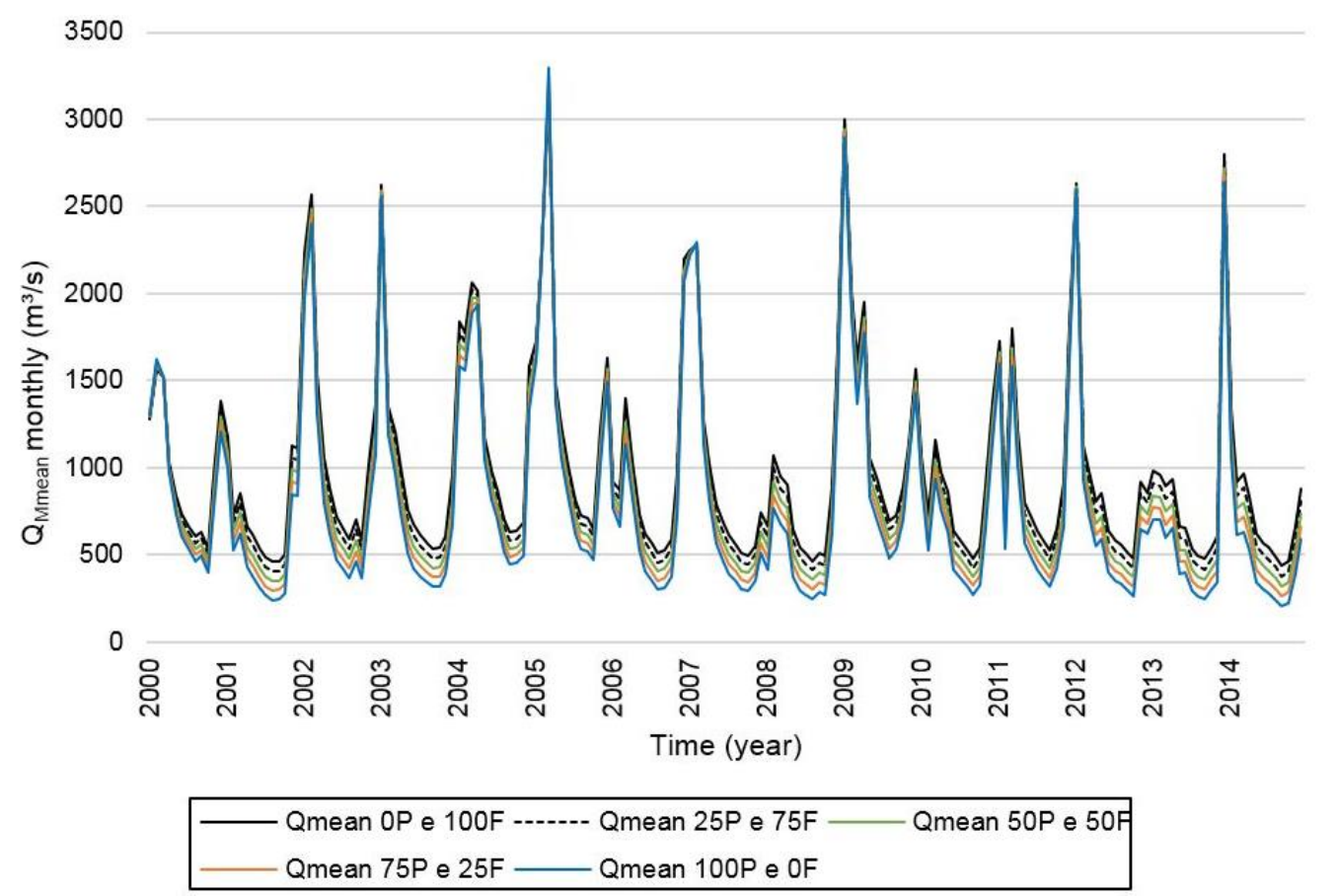

Figure 3. Monthly average discharge $\left(\mathrm{m}^{3} / \mathrm{s}\right)$ of the deforestation scenarios. 
According to the results, in the first three scenarios, there was not an increment in the annual average discharge, while there was in situations with $75 \%$ and $100 \%$ natural vegetation removal. This result was expected, since the land-use/cover map used (year 2000) has 70.29\% pasture and agricultural uses, and thus, only the scenarios with the highest percentages of pastures (75\% and 100\%) would imply in reductions in the annual average discharge. Considering all the scenarios, the one that considers $100 \%$ cover of natural forest has the largest increase $(16.29 \%-142.5 \mathrm{~m} / \mathrm{s})$ in an annual average flow, corresponding to $619 \mathrm{~mm}$ increase in annual flow. The average annual outflow for the $100 \%$ forest maintenance scenario was $985.12 \mathrm{~m} / \mathrm{s}$. Regarding the maximum annual discharge, in all the scenarios there was a decrease compared to the scenario of 2000 . On another hand, the minimum annual flows increased in all scenarios, except in the one with $100 \%$ pasture cover.

A $25 \%$ deforestation caused a rise in the annual maximum discharge of $68.69 \mathrm{~m}^{3} / \mathrm{s}$ and a reduction in the annual minimum flow of $52.85 \mathrm{~m}^{3} / \mathrm{s}$, and an annual average of $47.2 \mathrm{~m}^{3} / \mathrm{s}$, corresponding to a decrease in the outflow average of $205.4 \mathrm{~mm} /$ year when compared to the complete forest cover. This result is not consistent with the data found by Bosch and Hewlett (1982) and Collischonn (2001), who estimated, respectively, average increases of 10 to $25 \mathrm{~mm}$ and of $9 \mathrm{~mm}$ for every $10 \%$ reduction of deciduous forest. However, these results were measured in small basins (Bosch and Hewlett, 1982) or in a $26,900 \mathrm{~km}^{2}$ basin with high slope and soil type that favors the rapid generation of large floods (Collischonn, 2001). Similarly, when the 50, 75 and $100 \%$ pasture scenarios were simulated, there were reductions in the average and minimum annual discharges and a rise in the maximum annual flow.

It was observed that the $100 \%$ substitution into pasture caused a $5.99 \%\left(50.76 \mathrm{~m}^{3} / \mathrm{s}\right)$ reduction in the average annual discharge, while in the scenario of $100 \%$ forest caused a rise of $16.29 \%\left(138.03 \mathrm{~m}^{3} / \mathrm{s}\right)$, when compared to the year 2000 simulation. This result indicates a decrease in annual mean flows in deforestation scenarios, which is in agreement with the average behavior of the results obtained in experimental basins (Bosch and Hewlett, 1982; Collischonn, 2001). However, Caram (2010) and Beserra (2016), when performing hydrological simulations using MGB-IPH in watersheds located in the Brazilian Southeast region, as well as in the Doce River Basin, also found results contrary to the average behavior observed in experimental basins. Additionally, during long drought periods, the average flow tends to suffer more influence from the base flow, which reduced the average annual discharge. The decrease in annual mean flow rates in deforestation scenarios, especially in drought periods, can be explained by the greater capacity of storing water in the soil covered by forests. While the volume of water available for grazing is already depleted, forest vegetation continues to perspire at a normal rate, demonstrating one of the negative effects of deforestation and land conversion on pasture, aggravating the problem of water shortage in the basin.

The results suggest a rise in flood possibilities due to deforestation processes, which are consistent with the results found by Bayer (2014) and Andreassian (2004). On another hand, deforestation process results in the reduction of the annual minimum flows, also are in agreement with the previous papers (Caram, 2010; Beserra, 2016). The increase in floods caused by deforestation can be attributed to the hydrological role of surface water absorption forests and the regularization of liquid flows, avoiding floods. In this way, the replacement of forests by pastures or deforestation causes an increase in the occurrence of floods.

The permanence curve of sub-basin 11 was also analyzed (Figure 4). Related to the impact of deforestation on the minimum flows, we evaluated the Q95 flows (flows associated with the $95 \%$ permanence). There was a reduction of $11 \%$ in the scenario of $25 \%$ of deforestation, $23 \%$ in the $50 \%$ of deforestation, $34 \%$ in the $75 \%$ of deforestation and $46 \%$ in the $100 \%$ of deforestation. 


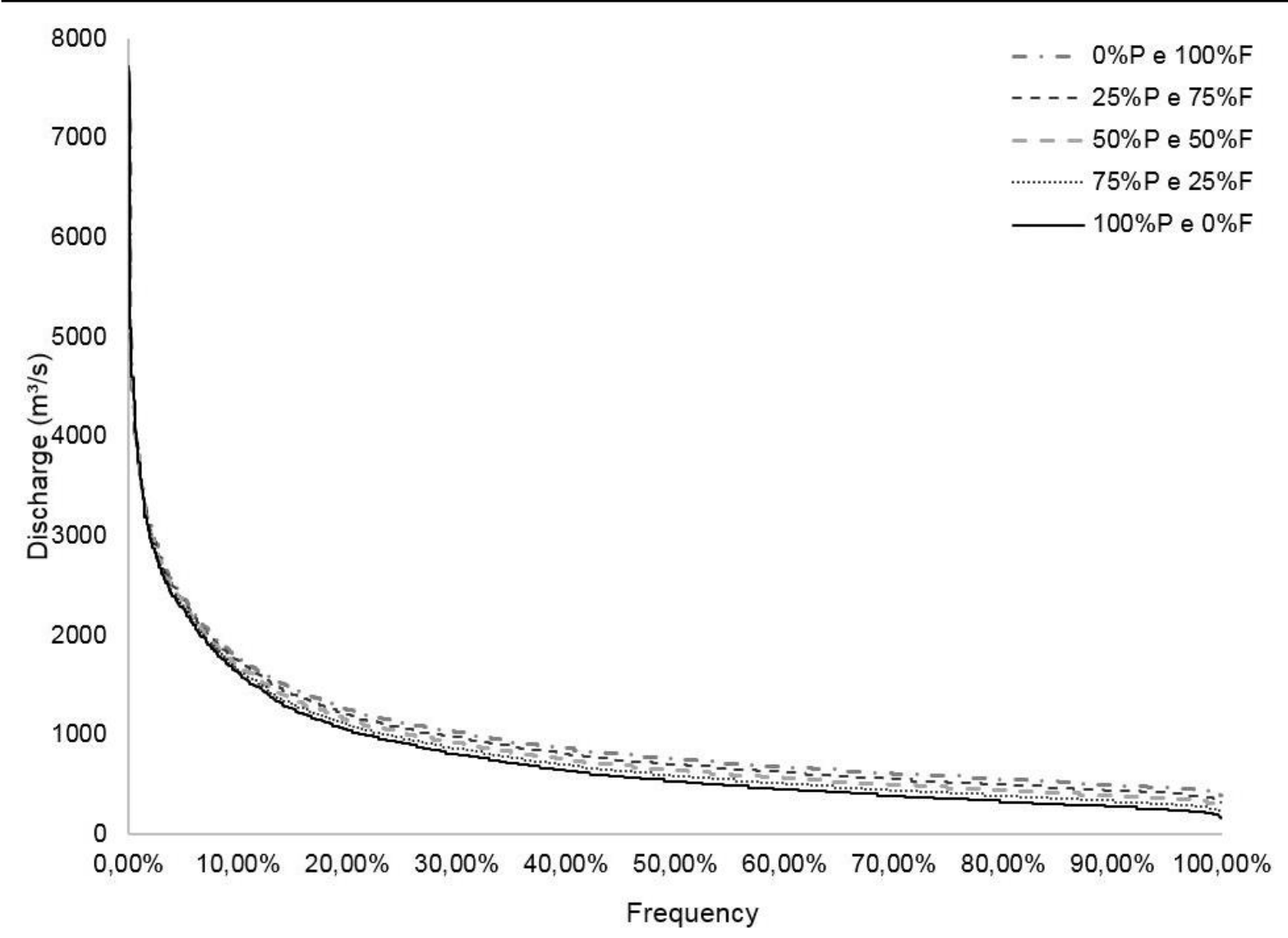

Figure 4. Permanence curve in sub-basin 11.

\section{CONCLUSION}

The MGB-IPH model had satisfactory adjustments for daily flow simulation in calibration (1990-2005) and validation period (2006 - 2014). It proved to be a powerful tool in hydrological simulations, suitable in the management of the water resources of this basin.

We verified that the replacement of forests by pastures caused reductions in annual average discharge, indicating a decrease in average flows in deforestation scenarios. On another hand, deforestation caused an increment in floods, unlike that of the minimum annual flows, which reduced with deforestation. Although these results are not in agreement with the average behavior of those obtained in experimental basins, they are consistent with studies carried out in other basins located in the Brazilian Southeast region.

Finally, the results from these simulated deforestation scenarios allow the anticipation of deteriorating problems that already exist in the basin, such as floods, due to the increments in maximum flows, and water scarcity with minimum flow reductions.

\section{REFERENCES}

ABBASPOUR, K. C.; ROUHOLAHNEJAD, E.; VAGHEFI, S.; SRINIVASAN, R.; YANG, H.; KLØVE, B. A continental-scale hydrology and water quality model for Europe: Calibration and uncertainty of a high-resolution large-scale SWAT model. Journal of Hydrology, v. 524, p. 733-752, 2015.

ANA (Brasil). Hidroweb - Sistema de Informações Hidrológicas. Available at: http://hidroweb.ana.gov.br Access: 4 July 2017. 
ANDREASSIAN, V. Waters and forests: from historical controversy to scientific debate. Journal of Hydrology, v. 291, n. 1-2, p. 1-27, 2004.

BAYER, D. M. Efeitos das mudanças de uso da terra no regime hidrológico de bacias de grande escala. 2014. 172 f. Tese (Doutorado em Recursos Hídricos e Saneamento Ambiental) - Universidade Federal do Rio Grande do Sul, Porto Alegre, 2014.

BESERRA, P. S. Avaliação dos efeitos das alterações na cobertura e uso do solo sobre o regime de vazões via modelagem hidrológica considerando incerteza paramétrica. 2016. 145f. Dissertação (Mestrado em tecnologia ambiental e recursos hídricos) Universidade de Brasília, Brasília, 2016.

BOSH, J. M.; HEWLETT, J. D. A review of catchment experiments to determine the effect of vegetation changes on water yield and evapotranspiration. Journal of Hydrology, v. 55, p. 3-23, 1982.

CARAM, R. O. Mudanças no uso e cobertura do solo e resposta hidrológica da bacia do rio Piracicaba. 2010. 141f. Tese (Doutorado em Ciências) - Universidade de São Paulo, São Paulo, 2010.

CBH-DOCE. Website. 2006. Available at: http://www.cbhdoce.org.br/. Access: Dez. 2017.

CGIAR. STRM 90m. Available at: http://www.cgiar.org/. Access: Dez. 2017.

COLLISCHONN, W. Simulação hidrológica de grandes bacias. 2001. 270f. Tese (Doutorado em Engenharia de Recursos Hídricos e Saneamento Ambiental) - Universidade Federal do Rio Grande do Sul, Porto Alegre, 2001.

CUPOLILLO, F.; ABREU, M. L.; VIANELLO, R. L. Climatologia da bacia do rio Doce e sua relação com a topografia local. Geografias, v. 4, n. 1, p. 45-60, 2008.

EMBRAPA. Mapa de solos do Brasil, 2001. Available at: http://www.dpi.inpe.br/Ambdata/mapa_solos.php. Access: Apr. 2017.

FAN, F. M; COLLISCHONN, W. Integração do Modelo MGB-IPH com Sistema de Informação Geográfica. RBRH - Revista Brasileira de Recursos Hídricos, v. 19, n. 1, p. 243-254, 2014.

IBGE. Mapa de Uso da Terra. 2000. Available at: https://www.ibge.gov.br/geocienciasnovoportal/informacoes-ambientais/cobertura-e-uso-da-terra.html. Access: Jan. 2018.

IBARRA-MONTOYA, J. L.; ROMAN, R.; GUTIÉRREZ, K.; GAXIOLA, J.; ARIAS, V.; BAUTISTA, M. Cambio en la cobertura y uso de suelo en el norte de Jalisco, México: Un análisis del futuro, en un contexto de cambio climático. Revista Ambiente \& Água, v. 6, n. 2, p. 111-128, 2011. https://dx.doi.org/10.4136/ambi-agua.189

INMET. Estações climatológicas. Available at: http://www.inmet.gov.br/projetos/rede/pesquisa/. Access: Feb. 2017.

PIRH-BACIA DO RIO DOCE. Plano Integrado de Recursos Hídricos da Bacia Hidrográfica do Rio Doce - PIRH Bacia do Rio Doce - Volume I. Consórcio EcoplanLume. 2010. Available at: http://www.cbhdoce.org.br/wpcontent/uploads/2014/10/PIRH_Doce_Volume_I.pdf. Access: Dec. 2016. 
PRADO, T. B. G. Evolução do uso das terras e produção de sedimentos na bacia hidrográfica do Rio Jundiaí-Mirim. 2005. 72f. Dissertação (Mestrado em Agricultura Tropical e Subtropical) - Universidade de Campinas, Campinas, 2005.

SHUTTLEWORTH, W. J. Evaporation. In: MAIDMENT, D. R. Handbook of hydrology. New York: McGraw-Hill, 1993. 


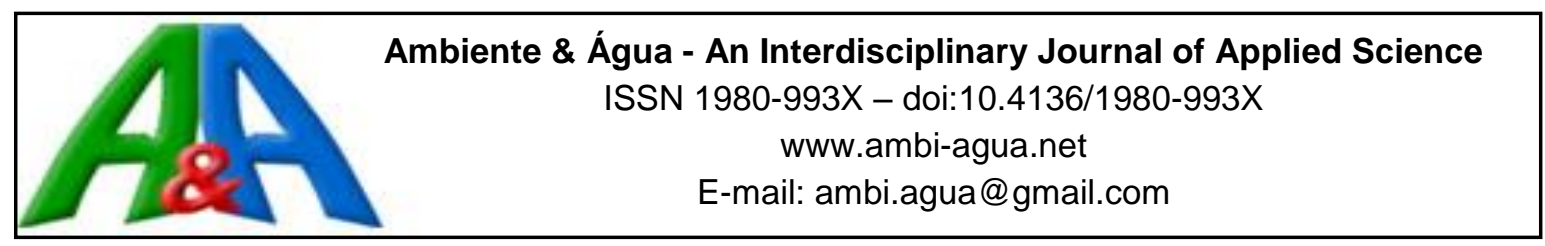

\title{
Analysis of cloud condition on Sentinel-2 MSI and Landsat-8 OLI images of a public supply lake in Belém-Pará-Brazil
}

\author{
ARTICLES doi:10.4136/ambi-agua.2375
}

Received: 08 Feb. 2019; Accepted: 26 May 2019

\author{
Vítor Abner Borges Dutra*iD; Paulo Amador Tavares ${ }^{(D)}$ \\ Hebe Morganne Campos Ribeiro \\ Universidade do Estado do Pará (UEPA), Belém, PA, Brasil \\ Programa de Pós-Graduação em Ciências Ambientais (PPGCA). \\ E-mail: vitordutra@uepa.br, paulo.tavares@uepa.br, hebemcr@gmail.com \\ *Corresponding author
}

\begin{abstract}
The eutrophication process leads to reduced water quality and economic losses worldwide. Furthermore, it is possible to apply remote sensing techniques for monitoring of aquatic environments. In this paper, we analysed the combined use of Sentinel-2 Multispectral Instrument and Landsat-8 Operational Land Imager data to monitor a eutrophic aquatic environment under adverse cloudy conditions, from July 2016 to July 2018. Data pre-selection was performed, and then the images were acquired for further investigation. After that, we created a key to the interpretation of cloud conditions for the study area and grouped each of 125 scenes in a Principal Component Analysis (PCA). The PCA grouped months with similarities in cloud conditions, highlighting their patterns in terms of the rainy and dry seasons for the study area. Another interesting result was that, even under the inherent adverse cloud regime of the Amazon, the combined use of both free satellite imagery data could be useful for further analyses, such as measuring of chlorophyll a, coloured dissolved organic matters, total suspended solids and turbidity. However, we highlight that, firstly, studies must be made to validate the data in situ, so that monitoring programs can be built through remote sensing applications.
\end{abstract}

Keywords: amazon waters, bolonha lake, remote sensing.

\section{Análise das condições de nuvens em imagens Sentinel-2 MSI e Landsat-8 OLI de um lago de abastecimento público em Belém-Pará- Brasil}

\section{RESUMO}

O processo de eutrofização leva à redução da qualidade da água e a perdas econômicas no mundo todo. Além disso, é possível aplicar técnicas de sensoriamento remoto para o monitoramento de ambientes aquáticos. Neste estudo, objetivou-se analisar o uso combinado dos dados Sentinel-2 Multispectral Instrument e Landsat-8 Operational Land Imager para o monitoramento de um ambiente aquático eutrofizado sob condições adversas de nuvens, de julho de 2016 a julho de 2018. Foi realizada a pré-seleção dos dados e posteriormente as cenas foram adquiridas para uma investigação mais aprofundada. Criou-se uma chave de 
interpretação para as condições de nuvens da área de estudo e foram agrupadas cada uma das 125 cenas em uma Análise de Componentes Principais (ACP). A ACP agrupou meses com similaridades nas condições de nuvens, destacando seus padrões em termos de estação chuvosa e seca para a área de estudo. Outro resultado interessante foi que, mesmo sob o regime adverso de nuvens inerente da Amazônia, o uso combinado de ambos dados de imagens de satélites gratuitos pode ser útil para uma análise mais aprofundada, como a mensuração de clorofila a, matéria orgânica colorida dissolvida, sólidos suspensos totais e turbidez. No entanto, destacase que, primeiramente, investimentos devem ser realizados de forma a validar dados in situ, para que um programa de monitoramento possa ser construído através de aplicações de sensoriamento remoto.

Palavras-chave: águas amazônicas, lago bolonha, sensoriamento remoto.

\section{INTRODUCTION}

Eutrophication is a process that causes water deterioration in lentic environments (Lobato et al., 2015) and also affects the spatial distribution of aquatic macrophytes (Madgwick et al., 2011; Søndergaard et al., 2010). These water vegetation contributes to primary productivity, sediment accumulation, provision of food and complex habitat for aquatic and semi-aquatic biota (Poikane et al., 2018). Furthermore, macrophytes act as integrators of environmental conditions to which they are exposed and thus can be used as long-term indicators for waterquality monitoring (Pall and Moser, 2009; Melzer, 1999).

Studies highlighted that current water-quality evaluation is limited due to three main factors: i) in-situ sampling and measurements of water-quality parameters are labour-intensive, time-consuming and expensive; ii) analysis of the spatial and temporal variations and water quality trends in large water bodies is almost impractical; and iii) the collected in-situ data is not $100 \%$ accurate considering the possibility of field-sampling or laboratory error (Gholizadeh et al., 2016; Ritchie et al., 2003).

In this context, remote sensing (RS) data and techniques offer a feasible means to explore spatial and temporal information, bringing a variety of insights related to tropical ecosystems (Martins et al., 2018; Yang et al., 2013). Among the RS possibilities for water quality monitoring, it is relevant to mention the use of open source data, such as Sentinel-2 Multispectral Instrument (S-2 MSI) and Landsat-8 Operational Land Imager (L-8 OLI) (Pahlevan et al., 2017; 2019), which we used in the analysis of this paper.

As a risk for future works in monitoring the environment, the US government started the process of reviewing the data fees for Landsat family products (Popkin, 2018). This payment would be a step backward for Earth observation, since more than 100,000 papers have been produced since 2008, when the Landsat products started to be freely available. Stone (2010) reinforces the importance of the free distribution of satellite data, once it has applicability in a vast range of public and private sectors of society.

S-2 MSI is composed of two individual satellites, 2A and 2B; the first one was launched in June 2015 and the second one in March 2017. They have thirteen spectral bands, four at $10 \mathrm{~m}$, six at $20 \mathrm{~m}$ and three at $60 \mathrm{~m}$ of spatial resolution. L-8 OLI was launched in February 2013. The satellite has nine spectral bands; except for the panchromatic $(15 \mathrm{~m})$, all the other bands work at $30 \mathrm{~m}$ of spatial resolution. The synergetic use of S-2 MSI and L-8 OLI for monitoring provides a temporal resolution of 2.9 days ( $\mathrm{Li}$ and Roy, 2017) and, after using image fusion techniques, a spatial resolution of 10 meters, is possible and usable for both images datasets aforementioned (Beltrão and Teodoro, 2018).

Applications with time series of Landsat products are a possibility for mapping and behaviour analysis of small water bodies in the Amazon (Arvor et al., 2018). Landsat historical

Rev. Ambient. Água vol. 14 n. 4, e2375 - Taubaté 2019 
series also offers the opportunity to analyse the ecological regime of floating macrophyte greenness throughout vegetation indexes (Terborgh et al., 2018). However, in the Amazon, the seasonal variability of the main atmospheric constituents represents a challenge for optical RS (e.g., cloudiness regime, the high aerosol burden in the dry season, among others) (Martins et al., 2018).

From this perspective, we aimed to analyse the combined use of S-2 MSI and L-8 OLI data in the Brazilian Amazon, considering a eutrophic aquatic environment under adverse conditions of clouds. Our study also aimed to build knowledge related to the possibilities of monitoring aquatic ecosystems in the region.

\section{MATERIAL AND METHODS}

\subsection{Study Area}

The Bolonha and Água Preta Lakes supply nearly $63 \%$ of the drinking water of the Metropolitan Region of Belém (MRB) (Pará, 2013). Both lakes are refuelled by the Guamá River waters (Bahia et al., 2008). They are located inside the Utinga State Park-Conservation Unit (USPCU) and cover $17.29 \%$ of its total area (240.85 out of 1393.088 ha) (Pará, 2013).

One of the main objectives of the creation of the USPCU was to ensure the water potability for the population of MRB (Pará, 2013). However, the pollution of Bolonha Lake due to the immoderate discharge of wastewater is causing its eutrophication and the overgrowth of water macrophytes over its surface (Pará, 2013; Ribeiro, 1992). Figure 1, made in QGIS 2.18.17, shows the location of the Bolonha Lake, used as the object of study.
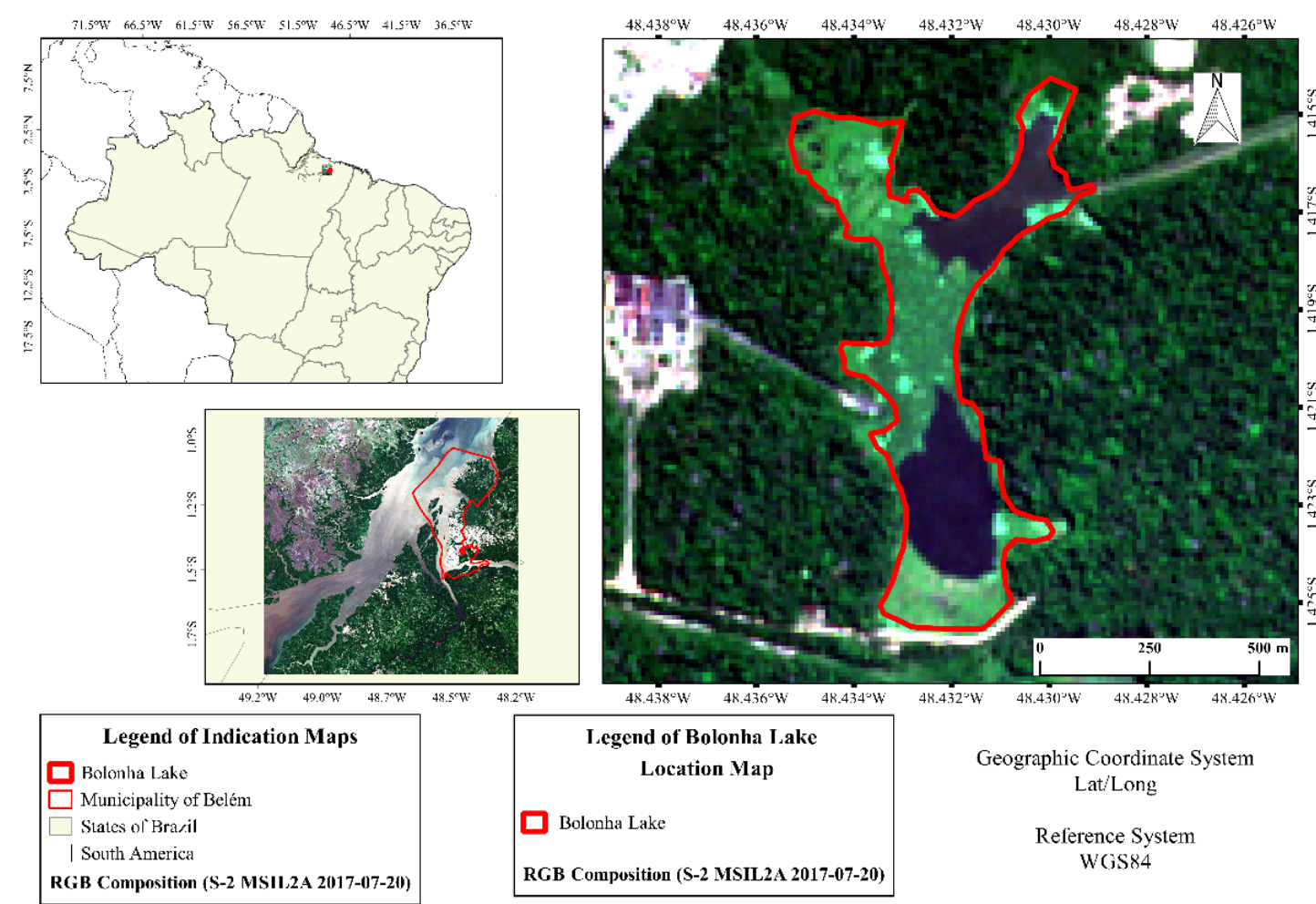
Geographic Coordinate System Lat/Long
Reference System WCSS 4

Figure 1. Location of the Bolonha Lake in Belém, Pará, Brazil. Source: ESA (2018).

\subsection{Image Selection and Key of Interpretation of the Cloud Conditions}

We considered all available S-2 MSI and L-8 OLI images from July 2016 to July 2018. We acquired the selected images in August 2018 in the Copernicus Open Access Hub (for S-2

\section{IPABH}


MSI) and the Earth Explorer of the United States Geological Survey (for L-8 OLI). After that, we classified the collected images for the Bolonha Lake in three different cloud conditions: i) lake without cloud cover; ii) lake under partial cloud cover; and iii) lake entirely covered by cloud (Table 1). The S-2 MSI's operations phase images were excluded because the atmospheric correction could not be applied to them; hence, they are not suitable for most of the RS applications.

Table 1. Key of Interpretation applied to the study area. The S-2's coloured compositions in the example column were standardised as RGB: B4, B3 and B2.

\begin{tabular}{lcc}
\hline Condition & Characteristics/Description \\
\hline $\begin{array}{l}\text { Lake without } \\
\text { cloud cover }\end{array}$ & $\begin{array}{c}\text { Cloud-free images of the surface of the lake, including water } \\
\text { mass, macrophytes and surrounding primary vegetation (e.g., S2A } \\
\text { 20180630) }\end{array}$ \\
$\begin{array}{l}\text { Lake under } \\
\text { partial cloud } \\
\text { cover }\end{array}$ & $\begin{array}{l}\text { Images that showed the lake under adverse conditions, but with a } \\
\text { clear distinction between macrophytes and water mass (e.g., S2A } \\
\text { 20180725) }\end{array}$ \\
$\begin{array}{l}\text { Lake entirely } \\
\text { covered by cloud }\end{array}$ & $\begin{array}{c}\text { Images not suitable for optical use, due to cloud obstruction of } \\
\text { water mass, macrophytes and surroundings of the lake (e.g., S2A } \\
\text { 20180426) }\end{array}$ \\
\hline
\end{tabular}

Source: ESA (2018).

This optical analysis was applied for all assessed images of the Bolonha Lake, scene by scene, and, even though there were scenes where the lake was under partial cloud cover, we distinguished which one of those scenes were optically useful for RS applications. The criterion we choose for this was the qualitative aspect of cloud fragments and shadows of cloud over the surface of the lake. With this criterion, we considered scenes as optically useful in situations where the cloud interferences could not affect the distinction of the water mass, the water vegetation and the primary vegetation around the Bolonha Lake.

We applied a quantitative approach, through PAST 3 software, to the filtered data using Principal Components Analysis (PCA) (Finkler et al., 2015; Venkata Krishnamoorthy and Reddy, 2019) for the useful images of the Bolonha Lake. In this analysis, we considered the groups of images classified as "lake without cloud cover" and "lake under partial cloud cover" that surpassed the criterion from the cloud interference as useful data; the remaining scenes summed up to not suitable scene data.

\section{RESULTS AND DISCUSSION}

\subsection{Data Classification and Characterization}

In the Bolonha Lake region, most of the S-2A MSI scenes were found in operational phase until June 2016, which left us the option to analyse only the subsequent scenes - in such a way 
that the combination of proper S-2 MSI and L-8 OLI images were considered. After the launch and operational phase of S-2B, the number of scenes to be investigated increased considerably.

We found 125 scenes for the study area within the satellite imagery data in the period assessed, from which 77 scenes were from the S-2 MSI satellite, with an annual distribution as follows: 11 from July to December 2016, 27 from January to December 2017 and 39 from January to July 2018. For the L-8 OLI satellite, we found 48 scenes, distributed as follows: 12 from July to December 2016, 23 from January to December 2017 and 13 from January to July 2018. The S-2 MSI and L-8 OLI scenes of the Bolonha Lake were classified and quantified in terms of their suitability for RS applications, as shown in Figure 2.

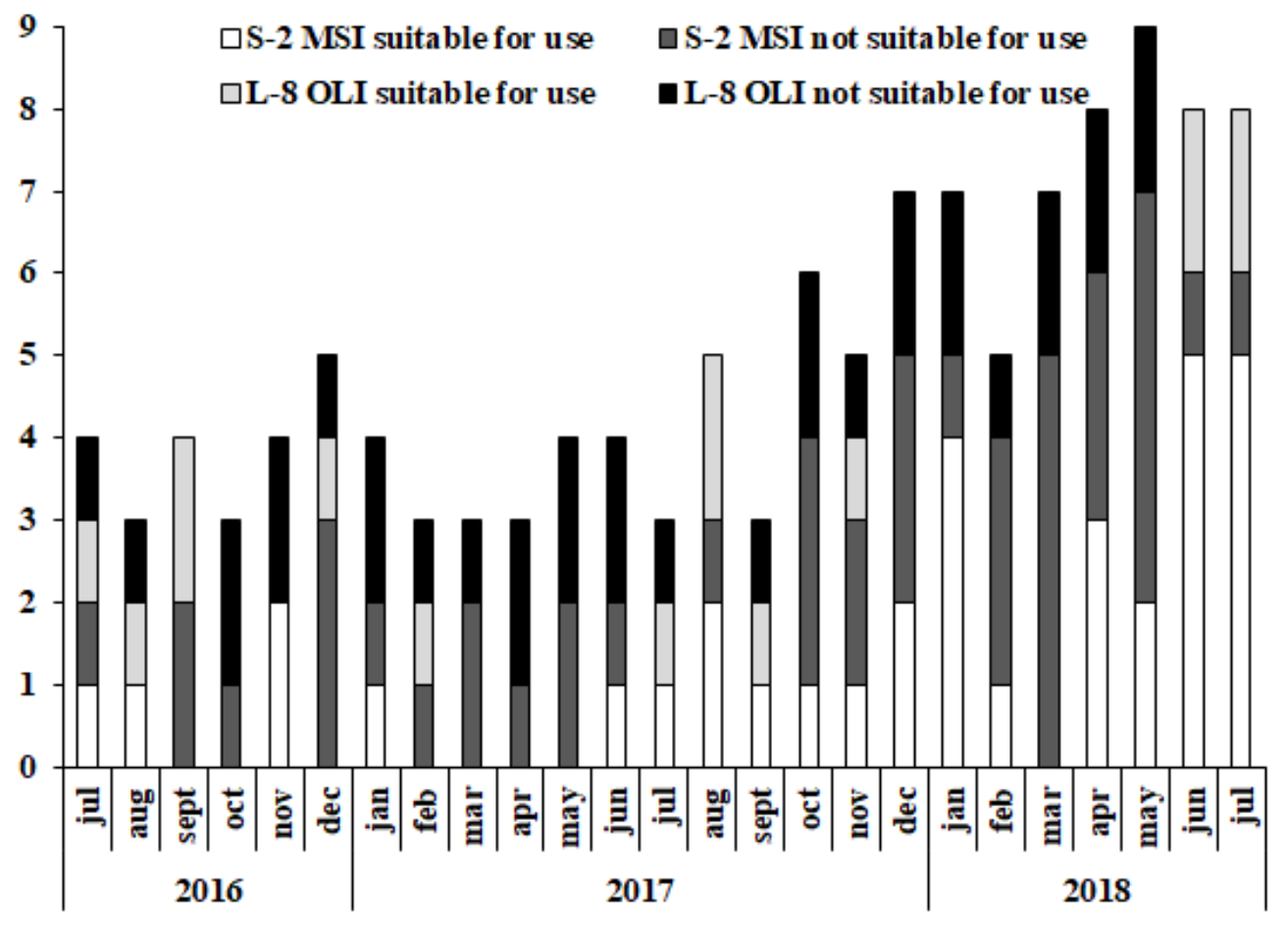

Figure 2. Classification of the suitability of S-2 MSI and L-8 OLI scenes for RS applications in terms of the cloud condition for all available data of the Bolonha Lake, from July 2016 to July 2018.

Due to its shorter revisit time (5 days) (ESA, 2015), S-2 MSI presented more available data than L-8 OLI (16 days) (USGS, 2016). The different sensing periods for the same area assisted in the selection of the optically useful images, improving temporal resolution for monitoring, agreeing with what is argued by Li and Roy (2017), e.g., in August 2017 there were four cloud-free images of the Bolonha Lake, being two of each satellite.

The gap of optically useful scenes between the months of March and May 2017 occurred because the S-2B satellite was still under the pre-launch phase (ESA, 2015). Furthermore, the L-8 OLI in the same period provided four scenes of the lake entirely covered by cloud and one scene where the Bolonha Lake was under partial cloud coverage - but with almost all pixels over the lake obstructed by clouds - i.e., those data were not suitable for RS applications.

The optical analysis and application of the key of interpretation resulted in 49 scenes of the study area suitable for RS applications, of which 34 were from S-2 MSI and 15 from L-8 OLI. We found around one useful scene per month of the Bolonha Lake (October 2016, March, April and May 2017 and March 2018 were the only months with no usable image found). This implies that the monitoring of aquatic environments using S-2 MSI and L-8 OLI imagery data is feasible even under the inherent excessive cloud regime of the Amazon (Martins et al., 2018). 
The results of the PCA of the first (78.6\%) and second (21.4\%) components, suitable S-2 MSI and L-8 OLI data and total satellite available data, respectively, pointed out three different groups (Figure 3). The similarities were found as follows: i) July to November 2016, January to July 2017 and September 2017 (red); ii) December 2016, October to December 2017 and February to May 2018 (green); and iii) August 2017, January 2018 and June, July 2018 (blue).

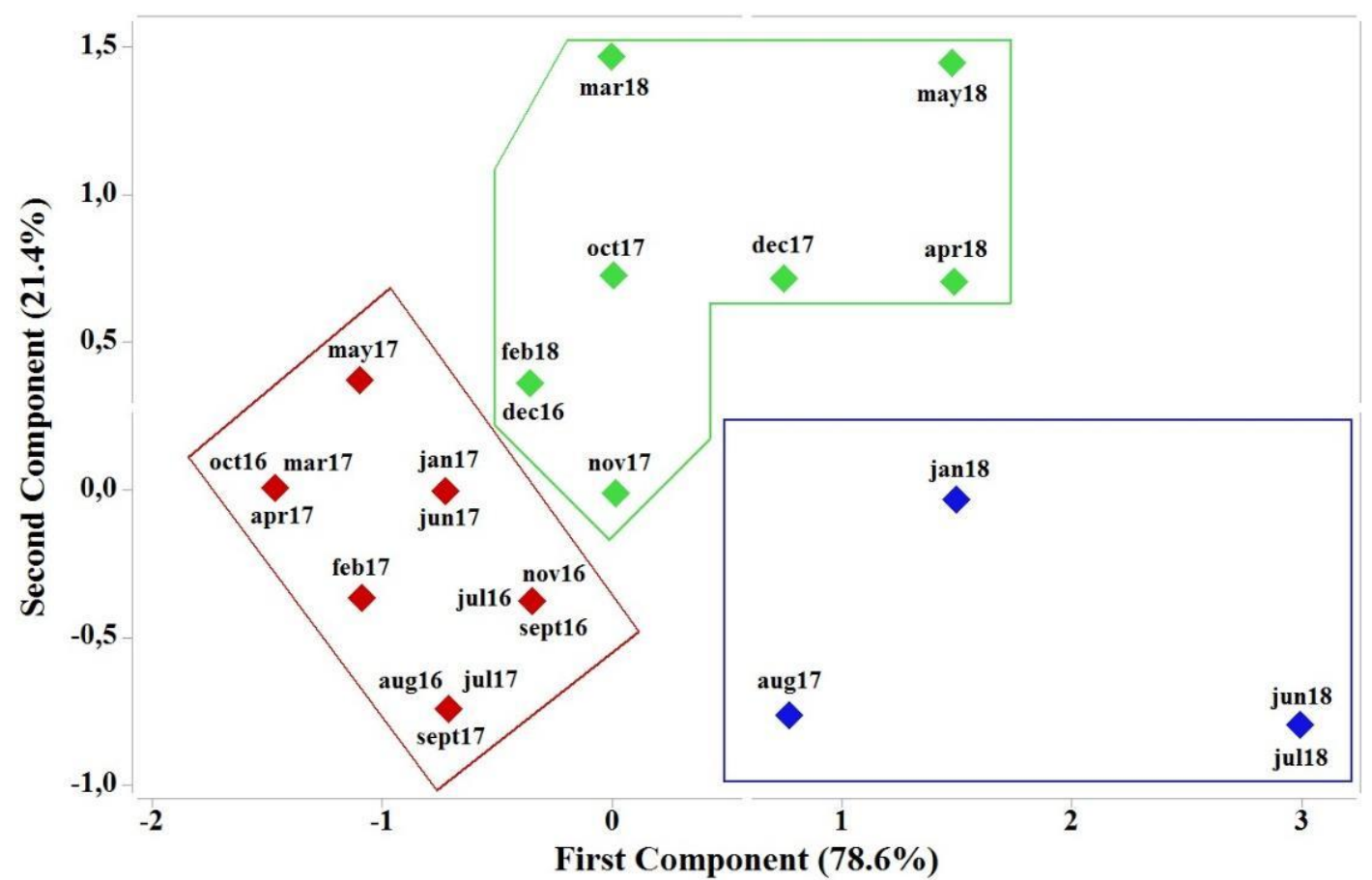

Figure 3. PCA illustrating the groups of similar months with overall cloud condition and useful S-2 MSI and L-8 OLI data for the Bolonha Lake.

The red group were assigned together due to the low availability and suitability of satellite data in these months. Prior to September 2017 (Figure 2), the S-2A was operating alone and giving a few imagery data of the study area. The temporal resolution of L-8 OLI could only delivery two scenes per month. Added to those factors, we highlight that the rainy season of USPCU occurs during December until May (INMET, 2019), which corroborates the fact that during this period the images are found covered by cloud more frequently.

The similarity of the green group, except for December 2016, was due to the launch of S2B satellite, which increased the temporal resolution over Bolonha Lake. This group presented more suitable optical data than the red group, even during the rainy season.

Lastly, the blue group, except for January 2018, was under the dry season in the USPCU area, i.e., the formation and density of clouds over the study area was much smaller than in the rainy season. This characterised a period with high availability of satellite data, in which almost all of them are suitable for optical RS applications; e.g., June and July 2018 both presented 16 available satellite data, from them, 14 scenes were optically useful for analysis of water parameters and its surface macrophytes of the Bolonha Lake.

There are few studies that attempted to demonstrate the suitability of combined S-2 MSI and L-8 OLI imagery (Pahlevan et al., 2019). Furthermore, investigations of cloud patterns usually select bigger areas and use different satellite instruments, such as Moderate Resolution Imaging Spectroradiometer (MODIS) (Garcia-Carreras et al., 2017).

Researches have highlighted different patterns of cloud cover over forested and deforested areas across distinct regions. Ray et al. (2003) studied the high occurrence of cumulus clouds over native vegetation areas in Southwest Australia. Teuling et al. (2017) analysed the 
substantial increase in cloud cover over large forest regions in Western Europe. Wang et al. (2009) investigated patterns of shallow cloudiness over deforested areas in Western Amazon. Durieux et al. (2003) found increased cloud cover over deforested regions due to the enhancement of seasonal contrasts in Eastern Amazon.

Considering the data from automatic weather stations in Eastern Amazon, Germano et al. (2017) analysed the breeze circulations inside USPCU between 2003 and 2012. The cloudcorrelated data were precipitation, wind speed and direction. The results showed that the effects of the sea breezes on the precipitation were more evident in Belém and other farther inland cities, which experienced a high frequency of precipitation from 15:00 to 21:00 UTC. Therefore, we can infer that the satellite data for the study area were very likely to be covered by clouds, considering the start sensing period of both S-2 MSI (13:42 UTC) and L-8 OLI (13:22 UTC).

\subsection{Optically Active Water Parameters}

The goal of most aquatic RS is to extract the radiance of interest from all the other radiance components being recorded by the sensor system. To identify the organic and inorganic constituents in the water column (e.g., chlorophyll a or total suspended solids), it is necessary to isolate the subsurface volumetric radiance $\left(\mathrm{L}_{\mathrm{v}}\right)$ from the total radiance $\left(\mathrm{L}_{\mathrm{t}}\right)$ (Equation 1). This process usually involves careful radiometric correction of the remote sensor data to remove atmospheric attenuation $\left(\mathrm{L}_{\mathrm{p}}\right)$, surface sun-glint and other surface reflection $\left(\mathrm{L}_{\mathrm{s}}\right)$, the radiance that entered the water column but was scattered into the upper hemisphere before reaching the bottom $\left(\mathrm{L}_{c}\right)$ and bottom reflectance $\left(\mathrm{L}_{b}\right)$. However, it is only possible to isolate and calculate $\mathrm{L}_{\mathrm{v}}$ within a region that is not cloud-shrouded (Legleiter and Roberts, 2005; Jensen, 2014).

$$
L_{v}=L_{t}-\left(L_{p}+L_{s}+L_{c}+L_{b}\right)
$$

RS data and techniques have been widely used to map the open water characteristics and their changes (Zhang et al., 2018). Some of the water parameters optically active and the RS data used for these applications in the literature investigated are detailed in Table 2.

Table 2. Commonly measured and optically active water qualitative parameters using RS.

\begin{tabular}{|c|c|c|}
\hline Water Quality Parameter & References & $\begin{array}{l}\text { Satellite/Sensor Data } \\
\text { Used }\end{array}$ \\
\hline \multirow{2}{*}{ Chlorophyll a (mg L-1) } & Novo et al. (2013) & \multirow{4}{*}{$\begin{array}{l}\text { L-5 TM }{ }^{1} \\
\text { S-2 MSI, L-8 OLI } \\
\text { MODIS, L-8 OLI, } \\
\text { RapidEye } \\
\text { S-2 MSI, S-3 OLCI }{ }^{2}\end{array}$} \\
\hline & Watanabe et al. (2017) & \\
\hline \multirow{2}{*}{ Coloured Dissolved Organic Matters $\left(\mathrm{mg} \mathrm{L}^{-1}\right)$} & Giardino et al. (2014) & \\
\hline & Ruescas et al. (2018) & \\
\hline \multirow{2}{*}{ Total Suspended Solids $\left(\mathrm{mg} \mathrm{L}^{-1}\right)$} & Umar et al. (2018) & \multirow{3}{*}{$\begin{array}{l}\text { L-5 TM } \\
\text { S-2 MSI, L-8 OLI } \\
\text { L-5 TM, L-8 OLI, } \\
\text { MODIS }\end{array}$} \\
\hline & Pahlevan et al. (2019) & \\
\hline \multirow{2}{*}{ Turbidity (NTU) } & Rudorff et al. (2018) & \\
\hline & Sakuno et al. (2018) & S-2 MSI \\
\hline
\end{tabular}

${ }^{1}$ Landsat 5 Thematic Mapper; ${ }^{2}$ Sentinel-3 Ocean and Land Colour Instrument.

Gholizadeh et al. (2016) described the satellites possibilities for monitoring of water parameters. For these authors, with the use of free Landsat data, it is possible to investigate the main water parameters that have optical responses. At the release date of their paper, the S-2 MSI was recently launched, so there was no trustworthy paper released yet, so the authors did not consider it in their article. However, in Table 2, we elucidate the possibilities of also using the S-2 MSI for the main water parameters estimation. The options of the identified optically

\section{IPABH}

Rev. Ambient. Água vol. 14 n. 4, e2375 - Taubaté 2019 
active water parameters, together with the number of images available during the year, per month, opens the opportunity of spatio-temporal monitoring the Bolonha Lake with reduced cost and for constant periods, increasing the understanding of the dynamics of this water body.

\section{FINAL CONSIDERATIONS}

Our study analysed the optically useful RS data for the USPCU, considering the possibility of further analysis for the study area and its qualitative water parameters. We could conclude that the synergic use of S-2 MSI and L-8 OLI surpasses the cloud issue, granting almost a monthly optical useful image data for small areas, such as Bolonha Lake. However, joint efforts of the public actors interested in the area must be made to validate the data locally during the rainy and dry seasons.

\section{REFERENCES}

ARVOR, D. et al. Monitoring thirty years of small water reservoirs proliferation in the southern Brazilian Amazon with Landsat time series. ISPRS Journal of Photogrammetry and $\begin{array}{llllll}\text { Remote } & \text { Sensing, } & \text { v. } & 145, & \text { p. } & 225-237,\end{array}$ https://doi.org/10.1016/j.isprsjprs.2018.03.015

BAHIA, V. E.; FENZL, N.; MORALES, G. P. Caracterização da qualidade das águas subterrâneas da bacia hidrográfica do Utinga/Belém (PA) - a partir de dados hidrogeoquímicos. In: CONGRESSO BRASILEIRO DE ÁGUAS SUBTERRÂNEAS, 15., 11-14 Nov. 2008, Natal. Anais[...] São Paulo: ABAS, 2008. p. 1-20.

BELTRÃO, N.; TEODORO, A. Evaluating the potential of Sentinel-2 MSI and Landsat-8 OLI data fusion for land cover mapping in Brazilian Amazon. In: REMOTE SENSING FOR AGRICULTURE, ECOSYSTEMS, AND HYDROLOGY, 20., 10-13 Sep., 2018, Berlin. Proceedings[...] Berlin: Spie, 2018. p. 7. https://doi.org/10.1117/12.2325576

DURIEUX, L.; MACHADO, L. A. T.; LAURENT, H. The impact of deforestation on cloud cover over the Amazon arc of deforestation. Remote Sensing of Environment, v. 86, n. 1, p. 132-140, 2003. https://doi.org/10.1016/S0034-4257(03)00095-6

ESA. Copernicus Open Access Hub. Available at: https://scihub.copernicus.eu/dhus/\#/home. Access: 2018.

ESA. Sentinel-2 User Handbook. 1. ed. Paris, 2015.

FINKLER, N. R. et al. Qualidade da água superficial por meio de análise do componente principal. Revista Ambiente \& Água, v. 10, n. 4, p. 782-792, 2015. http://dx.doi.org/10.4136/ambi-agua.1468

GARCIA-CARRERAS, L.; MARSHAM, J. H.; SPRACKLEN, D. V. Observations of Increased Cloud Cover over Irrigated Agriculture in an Arid Environment. Journal of Hydrometeorology, v. 18, n. 8, p. 2161-2172, 2017. https://doi.org/10.1175/JHM-D-160208.1

GERMANO, M. F. et al. Analysis of the breeze circulations in Eastern Amazon: an observational study. Atmospheric Science Letters, v. 18, n. 2, p. 67-75, 2017. https://doi.org/10.1002/as1.726 
GHOLIZADEH, M.; MELESSE, A.; REDDI, L. A Comprehensive Review on Water Quality Parameters Estimation Using Remote Sensing Techniques. Sensors, v. 16, n. 8, p. 1298, 2016. https://doi.org/10.3390/s16081298

GIARDINO, C. et al. Evaluation of Multi-Resolution Satellite Sensors for Assessing Water Quality and Bottom Depth of Lake Garda. Sensors (Switzerland), v. 14, n. 12, p. 2411624131, 2014. https://doi.org/10.3390/s141224116

INMET. Banco de Dados Meteorológicos para Ensino e Pesquisa - BDMEP. Available at: http://www.inmet.gov.br/portal/index.php?r=bdmep/bdmep. Access: 5 Feb. 2019.

JENSEN, J. R. Remote Sensing of the Environment: An Earth Resource Perspective. 2. ed. Essex: Pearson Education Limited, 2014.

LEGLEITER, C. J.; ROBERTS, D. A. Effects of channel morphology and sensor spatial resolution on image-derived depth estimates. Remote Sensing of Environment, v. 95, n. 2, p. 231-247, 2005. https://doi.org/10.1016/j.rse.2004.12.013

LI, J.; ROY, D. P. A Global Analysis of Sentinel-2A, Sentinel-2B and Landsat-8 Data Revisit Intervals and Implications for Terrestrial Monitoring. Remote Sensing, v. 9, n. 9, p. 117, 2017. https://doi.org/10.3390/rs9090902

LOBATO, T. C. et al. Categorization of the trophic status of a hydroelectric power plant reservoir in the Brazilian Amazon by statistical analyses and fuzzy approaches. Science of the Total Environment, v. 506-507, p. 613-620, 2015. https://doi.org/10.1016/j.scitotenv.2014.11.032

MADGWICK, G. et al. Centennial-scale changes to the aquatic vegetation structure of a shallow eutrophic lake and implications for restoration. Freshwater Biology, v. 56, n. 12, p. 2620-2636, 2011. https://doi.org/10.1111/j.1365-2427.2011.02652.x

MARTINS, V. S. et al. Seasonal and interannual assessment of cloud cover and atmospheric constituents across the Amazon (2000-2015): Insights for remote sensing and climate analysis. ISPRS Journal of Photogrammetry and Remote Sensing, n. October 2017, p. 1-19, 2018. https://doi.org/10.1016/j.isprsjprs.2018.05.013

MELZER, A. The Ecological Bases for Lake and Reservoir Management. 1. ed. [s.1.] Kluwer Academic Publishers, 1999. https://dx.doi.org/10.1007/978-94-017-3282-6

NOVO, E. M. L. DE M. et al. Proposal for a remote sensing trophic state index based upon Thematic Mapper/Landsat images. Revista Ambiente \& Água, v. 8, n. 3, p. 65-82, 2013. http://dx.doi.org/10.4136/ambi-agua.1229

PAHLEVAN, N. et al. Sentinel-2 MultiSpectral Instrument (MSI) data processing for aquatic science applications: Demonstrations and validations. Remote Sensing of Environment, v. 201, n. September, p. 47-56, 2017. https://doi.org/10.1016/j.rse.2017.08.033

PAHLEVAN, N. et al. Sentinel-2/Landsat-8 product consistency and implications for monitoring aquatic systems. Remote Sensing of Environment, v. 220, p. 19-29, 2019. https://doi.org/10.1016/j.rse.2018.10.027

PALL, K.; MOSER, V. Austrian Index Macrophytes (AIM-Module 1) for lakes: A Water Framework Directive compliant assessment system for lakes using aquatic macrophytes. Hydrobiologia, v. 633, n. 1, p. 83-104, 2009. https://doi.org/10.1007/s10750-009-9871-0

PARÁ. Plano de Manejo do Parque Estadual do Utinga. Belém: Ideflor-bio, 2013. 
POIKANE, S. et al. Macrophyte assessment in European lakes: Diverse approaches but convergent views of 'good' ecological status. Ecological Indicators, v. 94, n. March, p. 185-197, 2018. https://doi.org/10.1016/j.ecolind.2018.06.056

POPKIN, G. US government considers charging for popular Earth-observing data news. Nature, v. 556, n. 7702, p. 417-418, abr. 2018. https://doi.org/10.1038/d41586-01804874-y

RAY, D. K. et al. Effects of land use in Southwest Australia: 1. Observations of cumulus cloudiness and energy fluxes. Journal of Geophysical Research, v. 108, n. 14, p. 1-20, 2003. https://doi.org/10.1029/2002JD002654

RIBEIRO, H. M. C. Avaliação atual da qualidade das águas dos lagos Bolonha e Água Preta, situados na área fisiográfica do Utinga (Belém-Pará). 1992. Dissertação (Mestrado) - Centro de Geociências, Universidade Federal do Pará, Belém, 1992.

RITCHIE, J. C.; ZIMBA, P. V.; EVERITT, J. H. Remote Sensing Techniques to Assess Water Quality. Photogrammetric Engineering \& Remote Sensing, v. 69, n. 6, p. 695-704, 2003. https://doi.org/10.14358/PERS.69.6.695

RUDORFF, N. et al. Remote sensing monitoring of the impact of a major mining wastewater disaster on the turbidity of the Doce River plume off the eastern Brazilian coast. ISPRS Journal of Photogrammetry and Remote Sensing, v. 145, p. 349-361, 2018. https://doi.org/10.1016/j.isprsjprs.2018.02.013

RUESCAS, A. B. et al. Machine learning regression approaches for colored dissolved organic matter (CDOM) retrieval with S2-MSI and S3-OLCI simulated data. Remote Sensing, v. 10, n. 5, p. 1-25, 2018. https://doi.org/10.3390/rs10050786

SAKUNO, Y. et al. Evaluation of unified algorithms for remote sensing of chlorophyll-a and turbidity in Lake Shinji and Lake Nakaumi of Japan and the Vaal Dam Reservoir of South Africa under eutrophic and ultra-turbid conditions. Water (Switzerland), v. 10, n. 5, 2018. https://doi.org/10.3390/w10050618

SØNDERGAARD, M. et al. Submerged macrophytes as indicators of the ecological quality of lakes. Freshwater Biology, v. 55, n. 4, p. 893-908, 2010. https://doi.org/10.1111/j.13652427.2009.02331.x

STONE, R. Earth-observation summit endorses global data sharing. Science, v. 330, n. 6006, p. 902, 2010. https://doi.org/10.1126/science.330.6006.902

TERBORGH, J. W. et al. Twenty-three-year timeline of ecological stable states and regime shifts in upper Amazon oxbow lakes. Hydrobiologia, v. 807, n. 1, p. 99-111, 2018. https://doi.org/10.1007/s10750-017-3384-z

TEULING, A. J. et al. Observational evidence for cloud cover enhancement over western European forests. Nature Communications, v. 8, p. 1-7, 2017. https://doi.org/10.1038/ncomms14065

UMAR, M.; RHOADS, B. L.; GREENBERG, J. A. Use of Multispectral Satellite Remote Sensing to Assess Mixing of Suspended Sediment Downstream of Large River Confluences. Journal of Hydrology, v. 556, p. 325-338, 2018. https://doi.org/10.1016/j.jhydrol.2017.11.026

USGS. Landsat-8 Data User Handbook. 2. ed. Reston: United States Geological Survey, 2016.

Rev. Ambient. Água vol. 14 n. 4, e2375 - Taubaté 2019 
VENKATA KRISHNAMOORTHY, T.; REDDY, G. U. Cloud enhancement of NOAA multispectral images by using independent component analysis and principal component analysis for sustainable systems. Computers and Electrical Engineering, v. 74, p. 3546, 2019. https://doi.org/10.1016/j.compeleceng.2019.01.005

WANG, J. et al. Impact of deforestation in the Amazon basin on cloud climatology. Proceedings of the National Academy of Sciences, v. 106, n. 10, p. 3670-3674, 2009. https://doi.org/10.1073/pnas.0810156106

WATANABE, F. et al. Remote Sensing of the Chlorophyll-a Based on OLI/Landsat-8 and MSI/Sentinel-2A (Barra Bonita reservoir, Brazil). Annals of the Brazilian Academy of Sciences, p. 1-14, 2017. http://dx.doi.org/10.1590/0001-3765201720170125

YANG, J. et al. The role of satellite remote sensing in climate change studies. Nature Climate Change, v. 3, n. 10, p. 875-883, 2013. https://doi.org/10.1038/nclimate1908

ZHANG, S. et al. Effective water surface mapping in macrophyte-covered reservoirs in NE Brazil based on TerraSAR-X time series. International Journal of Applied Earth

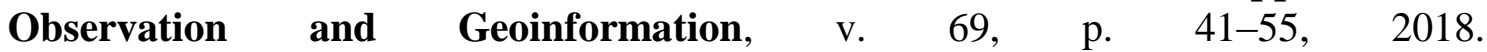
https://doi.org/10.1016/j.jag.2018.02.014 


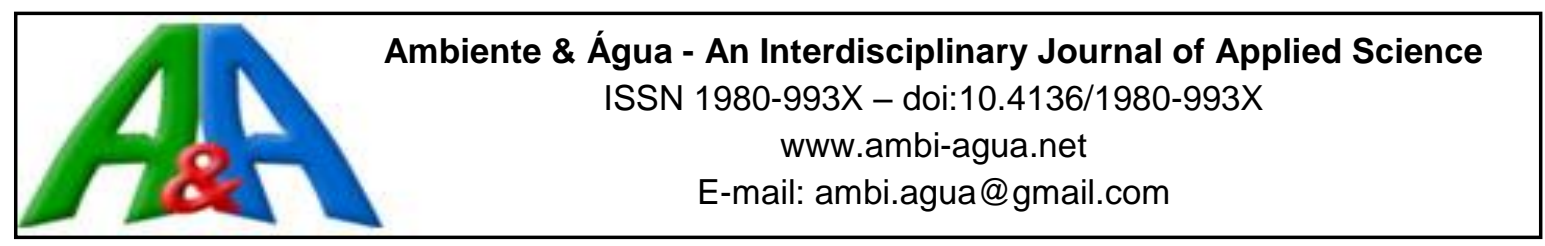

\title{
Influence of organic mulching on drip irrigation management of cabbage cultivation
}

\author{
ARTICLES doi:10.4136/ambi-agua.2381
}

Received: 25 Feb. 2019; Accepted: 26 May 2019

\author{
Andressa Scholz Berça ${ }^{\circledR}$; Thais Grandizoli Mendonça ${ }^{\circledR}$; Claudinei Fonseca Souza* \\ Universidade Federal de São Carlos (UFSCar), Araras, SP, Brasil \\ Departamento de Recursos Naturais e Proteção Ambiental (DRNPA). \\ E-mail: dessaberca@yahoo.com.br, grandizoli.thais@gmail.com,cfsouza@ufscar.br \\ *Corresponding author
}

\begin{abstract}
Irrigation has been pointed out in recent decades as the major consumer of water. Considering the need for a rational use of water resources and the importance of mulching for planting, this study evaluated the effect of organic mulching (sugarcane straw) under soil water storage for cabbage crop development. This research was conducted at CCA/UFSCar, and the experimental design was a completely randomized design with four replications and two treatments with and without sugarcane straw. Water application was performed by a drip irrigation system and irrigation management was determined from data collected by TDR. The use of organic mulching did not interfere with cabbage productivity under greenhouse conditions. The straw presents efficiency for reduction of soil evaporation and, consequently, increases water-use efficiency. The soil cover made it possible to save up to $28.1 \mathrm{~mm}(14.5 \%)$ of the water depth.
\end{abstract}

Keywords: sugarcane straw, TDR, trickle irrigation, water resources.

\section{Influência da cobertura morta orgânica no manejo da irrigação por gotejamento do cultivo de repolho}

\section{RESUMO}

A irrigação tem sido apontada nas últimas décadas como o maior consumidor de água. Considerando a necessidade de um uso racional dos recursos hídricos e a importância da cobertura morta para o plantio, o objetivo deste estudo foi avaliar o efeito da cobertura morta orgânica (palha de cana-de-açúcar) sob o armazenamento de água no solo para o desenvolvimento da cultura do repolho. Esta pesquisa foi conduzida no CCA/UFSCar e o delineamento experimental foi inteiramente casualizado, com quatro repetições e dois tratamentos com e sem palha de cana-de-açúcar. A aplicação de água foi realizada por um sistema de irrigação por gotejamento e o manejo da irrigação foi determinado a partir dos dados coletados pelo TDR. O uso da cobertura orgânica não interferiu na produtividade do repolho em condições de casa de vegetação. A palha apresenta eficiência para redução da evaporação do solo e, consequentemente, aumenta a eficiência do uso da água. Foi possível economizar até $28,1 \mathrm{~mm}(14,5 \%)$ de profundidade da água através da cobertura do solo.

Palavras-chave: irrigação localizada, palha de cana-de-açúcar, recursos hídricos, TDR. 
Andressa Scholz Berça et al.

\section{INTRODUCTION}

In recent years, the intensive and sustainable use of natural resources in agriculture has been the subject of several studies, with water and nutrients being the most limiting factors of agricultural production. According to Urbano et al. (2017), agricultural activity is responsible for $70 \%$ of the world's freshwater consumption; in Brazil this index reached $67.2 \%$ in 2016 and the forecast is that by 2030 the removal of water from natural resources will increase by $30 \%$ (ANA, 2017). Irrigation systems need to be operated with high levels of uniformity and efficiency in order to reduce water losses, leading to a rational food production in a growing world population. In this scenario, the search for more efficient irrigation methods that require fewer water resources and provide better results in productivity and quality has been intensified (Santoro et al., 2016).

Localized irrigation has been gaining ground for being one of the most efficient methods of water application, and the drip system has been recommended for most crops. In localized irrigation, water is applied in small volumes and high frequencies directly to the root zone of plants in order to maintain the moisture in the root zone close to the field capacity, allowing the best water use (Bizari et al., 2016). In addition, drip irrigation has several advantages, such as an increased water-use saving, potential to provide optimal management conditions for the development and productivity of plants, possibility of introducing a high level of automation, reducing the use of labor, and reducing the incidence and spread of phytopathogens.

In addition to irrigation management, other cultivation practices are necessary for the crop to produce its maximum potential, such as the use of organic mulching on the soil. Soil coverage with plant residues is presented as an agricultural practice that conserves the natural processes that maintain a stable temperature and reduces natural water losses by the evaporation process on the soil surface, providing an increase in water-use saving (Cortez et al., 2015). In this case, straw acts as a mechanical and thermal barrier on the soil, providing better water conservation (Murga-Orillo et al., 2016). Moreover, this practice allows maintaining or increasing soil organic matter content and mobilizing and recycling nutrients from residue decomposition (Silva et al. 2011), being effective for weed control (Moraes et al., 2013).

Considering the need for a rational use of water resources and the importance of mulching for planting, this study evaluated the effect of organic mulching (sugarcane straw) under soil water storage for cabbage crop development.

\section{MATERIAL AND METHODS}

The experiment was carried out in a greenhouse located in the experimental area of the Department of Natural Resources and Environmental Protection of the Center of Agricultural Sciences of the Federal University of São Carlos (DRNPA/CCA/UFSCar), Araras, SP, Brazil $\left(22^{\circ} 18^{\prime} 00^{\prime \prime} \mathrm{S}, 47^{\circ} 23^{\prime} 03^{\prime \prime} \mathrm{W}\right.$, and altitude of $\left.701 \mathrm{~m}\right)$. According to Köeppen system, the regional climate is classified as a mesothermal climate with warm and humid summers and dry winters.

The predominant soil in the experimental area is a very clayey Red Latosol (Oxisol) according to the Brazilian Soil Classification System (Santos et al., 2013). The analyses for characterizing soil physical and chemical attributes (Table 1) were conducted at the Laboratory of Soil Fertility and the Laboratory of Soil Physics of the UFSCar following the methods described by EMBRAPA (2011).

The experimental design was a completely randomized design with two treatments and four replications alternately arranged. Treatments consisted of beds with (T1) and without (T2) sugarcane straw, which were used as controls.

Rev. Ambient. Água vol. 14 n. 4, e2381 - Taubaté 2019 
Table 1. Physical and chemical characteristics of the soil, $0-0.20 \mathrm{~m}$ depth.

\begin{tabular}{lcc}
\hline Parameters & Units & Content \\
\hline Sand & $\%$ & 20 \\
Silt & $\%$ & 19 \\
Clay & $\%$ & 61 \\
Field capacity & $\mathrm{m}^{3} \mathrm{~m}^{-3}$ & 0.34 \\
Permanent wilting point & $\mathrm{m}^{3} \mathrm{~m}^{-3}$ & 0.17 \\
Total porosity & $\mathrm{m}^{3} \mathrm{~m}^{-3}$ & 0.51 \\
Bulk density & $\mathrm{kg} \mathrm{m}^{-3}$ & 1300 \\
Soil particle density & $\mathrm{kg} \mathrm{m}^{-3}$ & 2650 \\
Basic infiltration velocity & $\mathrm{cm} \mathrm{h}^{-1}$ & 13.20 \\
pH H $\mathrm{H}_{2} \mathrm{O}$ & - & 6.00 \\
Phosphorus & $\mathrm{mg} \mathrm{dm}^{-3}$ & 68.00 \\
Organic matter & $\%$ & 28 \\
Potential acidity & $\mathrm{mmol}_{\mathrm{c}} \mathrm{dm}^{-3}$ & 26.00 \\
Potassium & $\mathrm{mmol}_{\mathrm{c}} \mathrm{dm}^{-3}$ & 2.50 \\
Calcium & $\mathrm{mmol}_{\mathrm{c}} \mathrm{dm}^{-3}$ & 31.00 \\
Magnesium & $\mathrm{mmol}_{\mathrm{c}} \mathrm{dm}^{-3}$ & 13.00 \\
Sum of basis & $\mathrm{mmol}_{\mathrm{c}} \mathrm{dm}^{-3}$ & 46.30 \\
Cationic exchangeable capacity & $\mathrm{mmol}_{\mathrm{c} \mathrm{dm}^{-3}}$ & 72.30 \\
Base saturation & $\%$ & 64 \\
Sulfur & $\mathrm{mg} \mathrm{dm}^{-3}$ & 72.00 \\
Boron & $\mathrm{mg} \mathrm{dm}^{-3}$ & 0.10 \\
Copper & $\mathrm{mg} \mathrm{dm}^{-3}$ & 4.80 \\
Iron & $\mathrm{mg} \mathrm{dm}^{-3}$ & 92.00 \\
Manganese & $\mathrm{mg} \mathrm{dm}^{-3}$ & 1.80 \\
Zinc & $\mathrm{mg} \mathrm{dm}^{-3}$ & 1.40 \\
\hline
\end{tabular}

The greenhouse had eight beds $2.1 \mathrm{~m}$ wide and $2.1 \mathrm{~m}$ long, totaling an area of $4.41 \mathrm{~m}^{2}$. Each bed was composed of 28 plants of the hybrid cabbage Astrus Plus (Brassica oleracea L. var. capitata L.), whose seedlings were transplanted manually, spaced $0.70 \mathrm{~m}$ between rows and $0.30 \mathrm{~m}$ between plants in a triangular configuration.

Relative air humidity and temperature were monitored daily over the experimental period by using a meteorological station installed inside the greenhouse. The necessary phytosanitary treatments were also carried out, as well as manual weed elimination.

The amounts of nutrients applied via fertigation were determined considering Table 1 and following the doses according to Raij et al. (1997). Planting fertilization was carried out with a solid fertilizer in a half-moon application of $7 \mathrm{~g}$ potassium sulfate plant $^{-1}, 0.6 \mathrm{~g}$ potassium nitrate plant $^{-1}, 25 \mathrm{~g}$ single superphosphate plant $^{-1}, 1.4 \mathrm{~g}$ calcium nitrate plant $^{-1}$, and $0.5 \mathrm{~g}$ boric acid plant $^{-1}$. Topdressing fertilization was carried out via fertigation every fortnight until 60 days after planting, with1.4 g potassium nitrate plant ${ }^{-1}$ being applied and $3 \mathrm{~g}$ calcium nitrate plant $^{-1}$ per application.

After manual seedling transplanting and planting fertilization, $9 \mathrm{t} \mathrm{ha}^{-1}$ of sugarcane straw were distributed in the beds (Pereira et al., 2002) (Figure 1).

Water application was performed by a drip irrigation system with 4 L h-1 selfcompensating emitters installed near each plant base. Two TDR probes with $0.20 \mathrm{~m}$ long rods were buried vertically within the working area of each bed. 

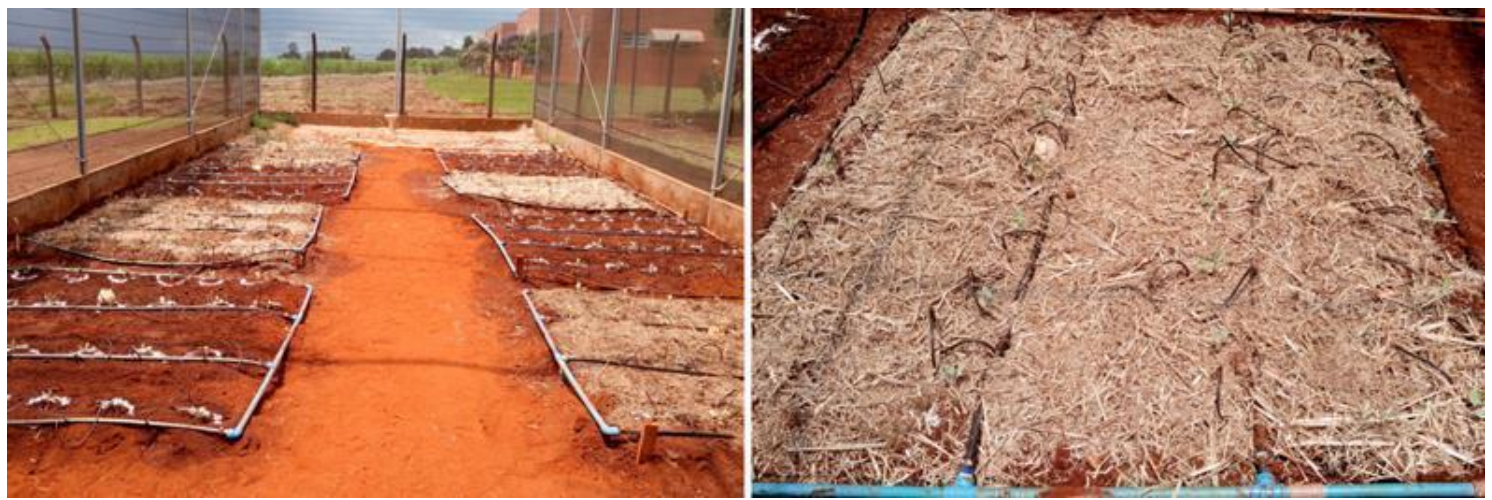

Figure 1. Greenhouse after planting fertilization and sugarcane straw distribution and detail in the bed with organic mulching.

Before the beginning of the experiment, a test was performed to verify the uniformity of water distribution of the localized irrigation system. In this test, flow rates were measured in four emitters per bed, one per lateral row. Water application uniformity was estimated using the flow rate of each assessed emitter as a function of the Christiansen's uniformity coefficient (CUC), determined by the Equation 1 described by Andrade et al. (2017) and Santoro et al. (2016):

$$
\mathrm{CUC}=100\left[1-\sum_{\mathrm{i}=1}^{\mathrm{n}} \frac{\left(\mathrm{q}_{\mathrm{i}}-\mathrm{q}_{\mathrm{m}}\right)}{\mathrm{N}_{\mathrm{qm}}}\right]
$$

Where:

$\mathrm{q}_{\mathrm{i}}$ - flow rate of each emitter $\left(\mathrm{L} \mathrm{h}^{-1}\right)$;

$\mathrm{q}_{\mathrm{m}}$ - average flow rate of emitters $\left(\mathrm{L} \mathrm{h}^{-1}\right)$;

$\mathrm{N}_{\mathrm{qm}}$ - number of emitters.

Irrigation management was determined from data collected daily by using a Campbell Scientific $®$ TDR100, thus maintaining soil moisture in the root system area at field capacity $\left(0.34 \mathrm{~m}^{3} \mathrm{~m}^{-3}\right)$ and avoiding water stress of plants. In addition, management was performed separately for each treatment. Readings were registered daily at 7:00 h and irrigation applied three times a day $(8 \mathrm{~h} 00,12 \mathrm{~h} 00$, and $17 \mathrm{~h} 00)$.

TDR probe provided the apparent dielectric constant (Ka) of soil, which was replaced in Equation 2 (Souza et al., 2017), obtained from the calibration for this soil.

$\theta=0.000005 K a^{3}-0.0003 K a^{2}+0.0161 K a^{1}+0.0132$

Where:

$\theta$ - soil moisture;

$\mathrm{Ka}$ - apparent dielectric constant of soil.

Irrigation water depth was calculated by means of soil moisture content of each treatment, as Equation 3.

$$
N I D=\left(\theta_{f c}-\theta_{T D R}\right) \times d_{e f f} \times 1000
$$

Where:

NID - net irrigation water depth (mm);

$\theta_{\mathrm{fc}}-$ soil moisture at field capacity;

$\theta_{\text {TDR }}$ - soil moisture obtained with Souza et al. (2017) equation;

$\mathrm{d}_{\text {eff }}$ - effective root depth $(0.25 \mathrm{~m})$. 
TDR probe also provided values of soil electrical conductivity. However, Equation 4 (Souza et al., 2017) was necessary to suit the soil used.

$$
E C=0.0303+\left(4.602 \times E C_{T D R}\right)-(0.7 \times \theta)
$$

Where:

EC - soil electrical conductivity $\left(\mathrm{dS} \mathrm{m} \mathrm{m}^{-1}\right)$;

$\mathrm{EC}_{\mathrm{TDR}}$ - electrical conductivity provided by $\mathrm{TDR}\left(\mathrm{dS} \mathrm{m} \mathrm{m}^{-1}\right)$;

$\theta$ - soil moisture obtained with Souza et al. (2017) equation.

Cabbage was harvested about 90 days after planting the seedlings, only 10 plants were selected, corresponding to the useful area of the bed, not considering the border plants. Harvested plants were weighed in an analytical balance in order to obtain the fresh mass of each bed.

After harvesting, a foliar analysis was performed to verify the mineral composition of cabbage leaves of both treatments, including the macronutrients nitrogen $(\mathrm{N})$, phosphorus $(\mathrm{P})$, potassium $(\mathrm{K})$, calcium $(\mathrm{Ca})$, magnesium $(\mathrm{Mg})$, and sulfur $(\mathrm{S})$, and the micronutrients boron (B), copper $(\mathrm{Cu})$, iron $(\mathrm{Fe})$, manganese $(\mathrm{Mn})$, and zinc $(\mathrm{Zn})$. For this analysis, samples were obtained by removing four wrapping leaves from the cabbage heads of the useful area of each bed, totaling 32 diagnostic leaves.

At the end of the experiment, the water use efficiency (WUE $-\mathrm{kg} \mathrm{m}^{-3}$ ) was estimated through the relationship between productivity of each treatment and the amount of water used during the crop cycle.

The results of soil moisture, water depth, soil electrical conductivity, and fresh mass were analyzed statistically by means of the t-test at $5 \%$ significance level using the software $\mathrm{R}$ version 3.2.0 (R Core Team, 2015).

\section{RESULTS AND DISCUSSION}

During the cabbage cultivation cycle, three flow tests were carried out to determine the distribution uniformity of the emitters after a six-minute system run time. It was possible to obtain a uniformity coefficient of $94.1 \%$ and an average flow of $4.04 \mathrm{~L} \mathrm{~h}^{-1}$.

The averages of temperature and relative air humidity during the experimental period were $23^{\circ} \mathrm{C}$ and $77 \%$, ranging from 18.4 to $27.1^{\circ} \mathrm{C}$ and 64.7 and $91.9 \%$, respectively (Figure 2). These conditions were favorable for crop growth, as observed by Silva Júnior (1989), who states that cabbage production is favored in mild climate conditions.

Regarding soil moisture variation during the cabbage cycle (Figure 3), sugarcane straw provided $3.7 \%$ increase in the average soil water storage, decreasing the water depth to be applied by irrigation when compared to the treatment without organic mulching. A statistically significant difference was observed between the average moisture of treatments, with a p-value equivalent to 0.001367 .

Stone and Moreira (2000) observed that mulching efficiency from crop residues is the most important factor to explain the higher water content found in soils under the no-tillage system when compared to the conventional system, since straw acts in the first phase of the water evaporation process, reducing the rate of daily evaporation due to the reflection of radiant energy. In addition, Ferreira et al. (2015) reported that the highest water conservation in the mulch system was related to the straw remaining on the soil surface, providing a greater reflection of the incident solar radiation and, therefore, acting as a barrier against water evaporation. 


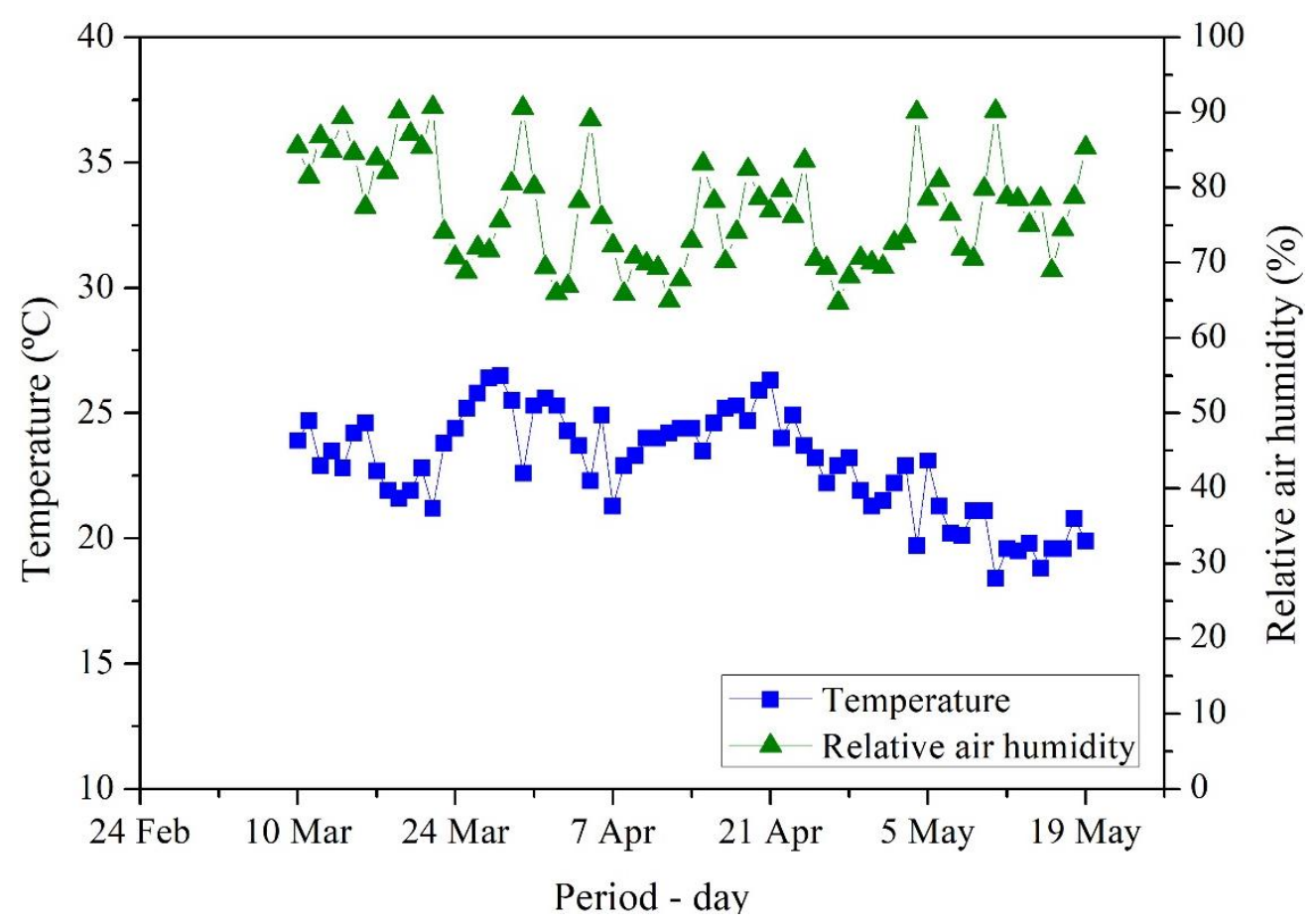

Figure 2. Daily averages of temperature and relative air humidity of the greenhouse during the experimental period.

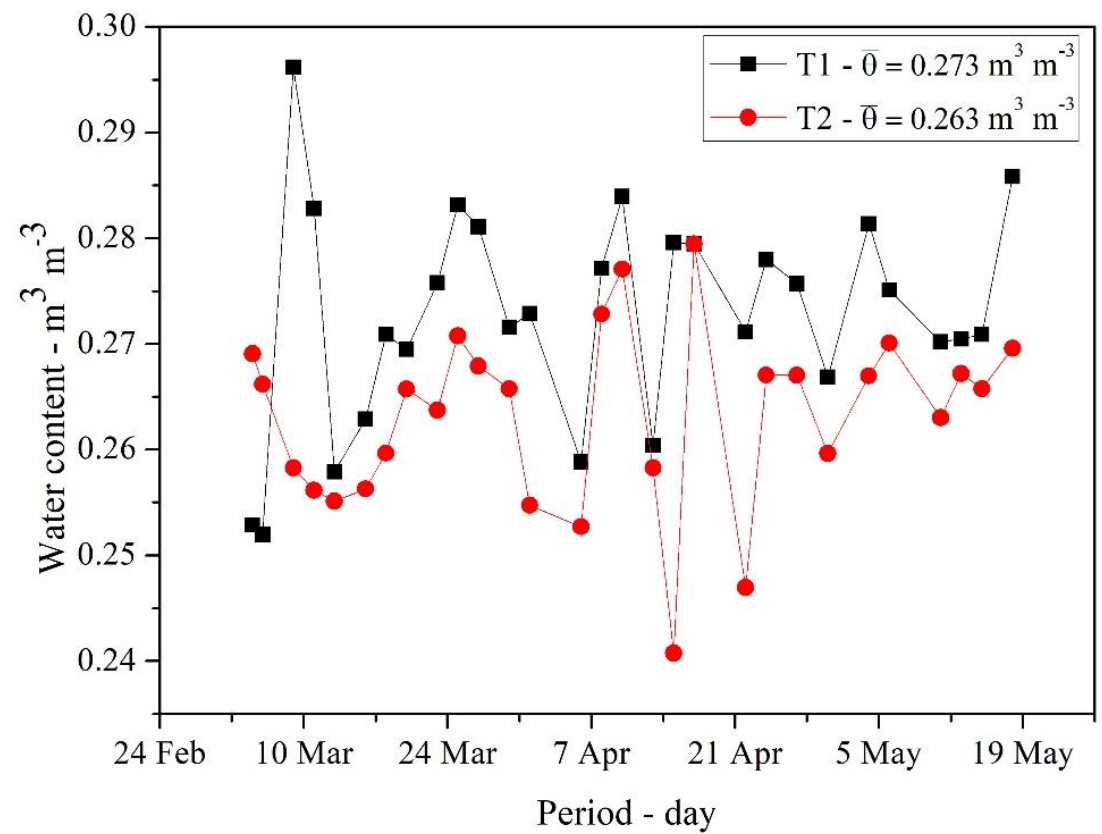

Figure 3. Variation and average soil water content during cabbage cycle for different treatments (T1- with sugarcane straw and T2 without sugarcane straw).

The total water depth applied during the cabbage cycle was determined by means of the data collected daily (Figure 4). The total water depth was $165.4 \mathrm{~mm}$ with the mulching treatment and $193.5 \mathrm{~mm}$ in the treatment without sugarcane straw. Comparatively, a $28.1 \mathrm{~mm}$ savings of water was observed in the organic mulching treatment, T1. According to the statistical test, a significant difference was observed in the water depths between treatments, with a p-value equivalent to 0.0002400 . 


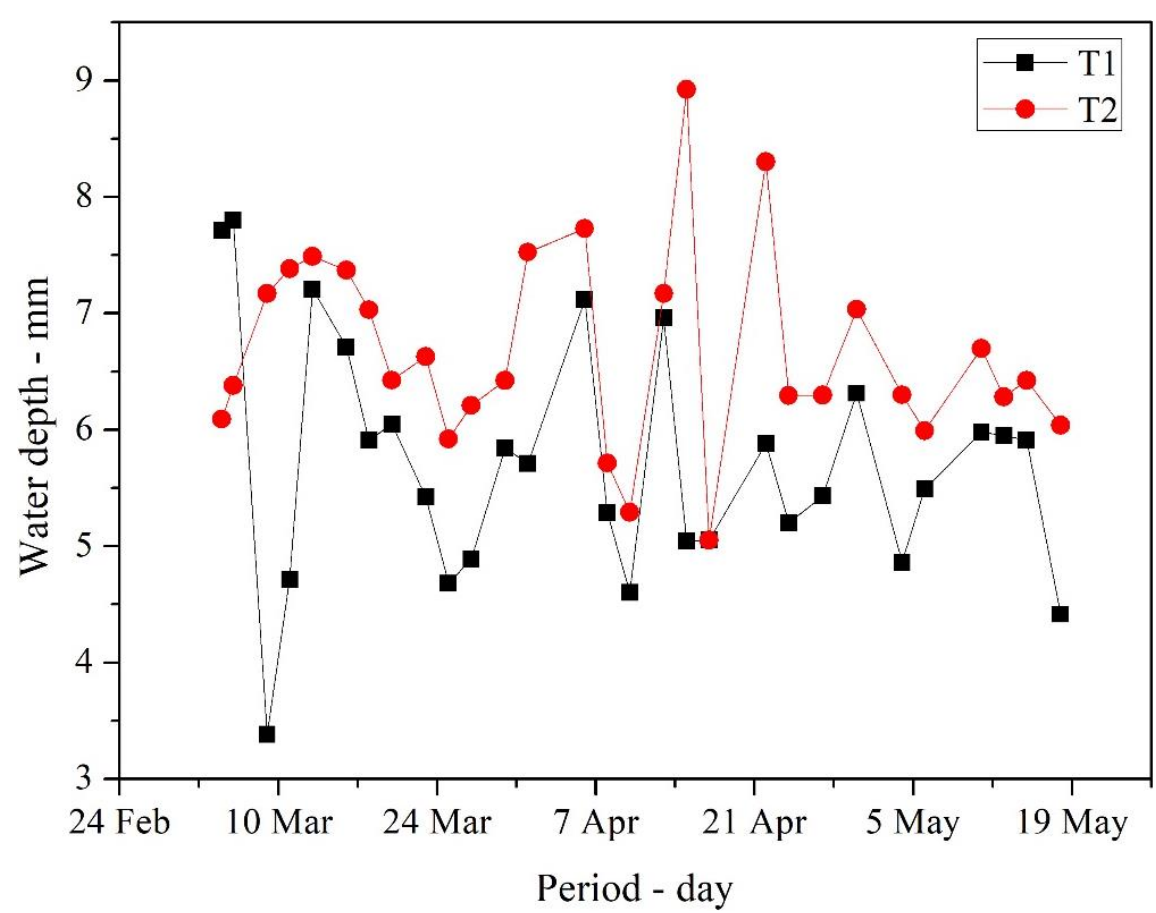

Figure 4. Water depths applied daily during the cabbage cycle.

The values of soil electrical conductivity during the cabbage cycle obtained from data collected through TDR100 are shown in Figure 5. The averages of treatments with and without organic mulching were 0.0198 and $0.0183 \mathrm{dS} \mathrm{m}^{-1}$, respectively. The statistical analysis showed no significant difference between treatments, with a p-value equivalent to 0.8426 . Thus, organic mulching did not influence soil electrical conductivity, i.e., it did not retain salts in the soil and did not alter the availability of nutrients to the plants, acting on this variable in a similar way to the treatment without sugarcane straw.

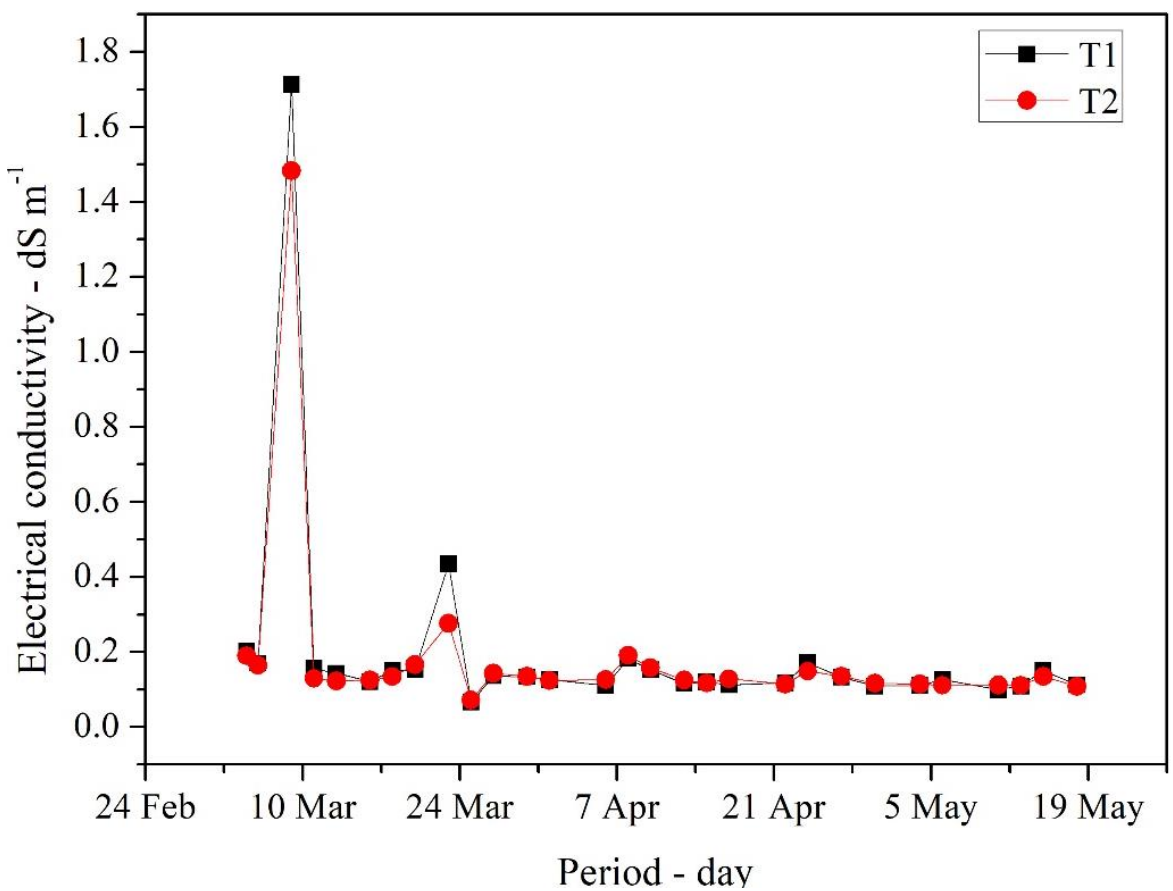

Figure 5. Soil electrical conductivity during the cabbage cycle.

Two electrical conductivity peaks can be noticed in both treatments when analyzing Figure 5. This behavior may be explained by the drip irrigation, which tends to decrease the content of 
salts near the plant, thus reducing soil electrical conductivity over the days after the peak, and by the fertigation carried out on March 9 and 23, which contained potassium nitrate. According to Bonini et al. (2014), the values of electrical conductivity found are within the limits of normality, since a soil is considered as saline when its values exceed $4 \mathrm{dS} \mathrm{m}^{-1}$, which may impair crop development.

The sugarcane straw provided a greater functionality for the reduction of water evaporation and the economics of the applied water depth, not interfering with the productivity parameter, $\mathrm{T} 1-54.2 \mathrm{tha}^{-1}$ and $\mathrm{T} 2-55.2 \mathrm{tha}^{-1}$. No significant difference was observed regarding the fresh mass of each treatment, with a p-value equivalent to 0.7904 . This result is in accordance with Moura et al. (2006), who also observed that the plant stand, productivity, diameter, height, and compactness of cabbage heads were not significantly affected by treatments, i.e., productivity and quality of cabbage in the mulching treatment were similar to those obtained in the treatment without mulching, even with a lower amount of water (Figure 6).

Also, considering the volume of water applied through irrigation, water-use efficiency (WUE) was $32.8 \mathrm{~kg} \mathrm{~m}^{-3}$ in the treatment with cabbage cultivated with mulch and $28.5 \mathrm{~kg} \mathrm{~m}^{-3}$ in plants without soil cover. The WUE result confirms that to produce the same amount of cabbage with straw it is necessary to provide approximately $85.5 \%$ of the water demanded for the conventional system. According to Medrano et al. (2015), this greater WUE is due to the presence of organic mulching in an adequate amount, reducing the losses by water evaporation from the soil profile. This water saving is in accordance with Freitas and Landers (2014), who reported an average reduction in the demanded water for irrigation of $15 \%$ in systems that use mulching on the soil when considering different crops. In fact, straw provides a slower depletion of water in the soil, increasing the irrigation shift and the application of less water during the crop cycle, in addition to favoring a reduction in the operational irrigation costs.

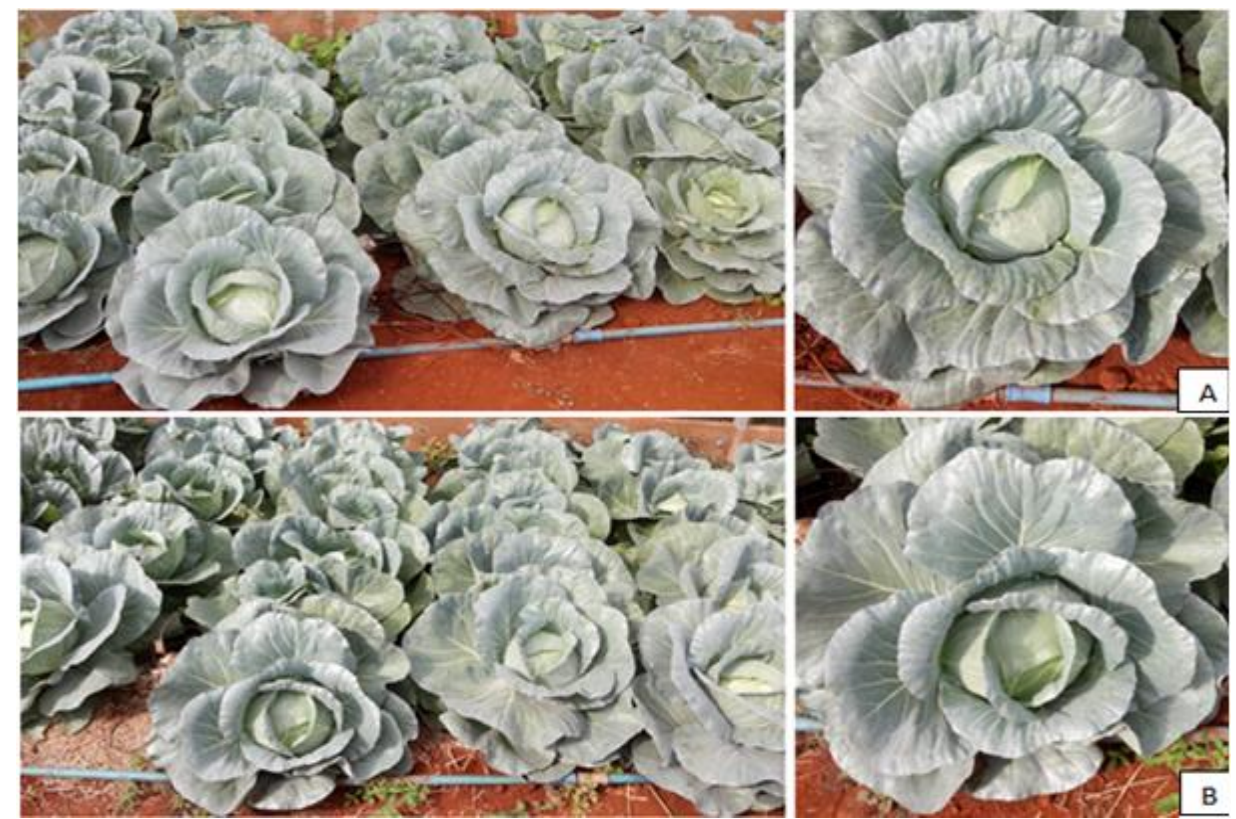

Figure 6. Plants from the treatment without $(\mathrm{A})$ and with sugarcane straw $(\mathrm{B})$.

A possible reason for this insignificant difference in cabbage production may be related to the irrigation management. In this case, irrigation was carried out individually for each treatment in order to maintain the root system area with moisture in the field capacity and with a sufficient amount of water to supply the water requirements of plants, i.e., without excesses or deficits, avoiding plant stress.

No significant difference was observed between treatments for leaf analysis (Table 2).

Rev. Ambient. Água vol. 14 n. 4, e2381 - Taubaté 2019 
Thus, the levels of macro- and micronutrients were similar for plants submitted to the treatments with and without organic mulching.

Table 2. Average mineral composition of macronutrients $\left(\mathrm{g} \mathrm{kg}^{-1}\right)$ and micronutrients $\left(\mathrm{mg} \mathrm{kg}^{-1}\right)$ in the cabbage leaves for both treatments.

\begin{tabular}{cccccccccccc}
\hline Treatment & $\mathrm{N}$ & $\mathrm{P}$ & $\mathrm{K}$ & $\mathrm{Ca}$ & $\mathrm{Mg}$ & $\mathrm{S}$ & $\mathrm{B}$ & $\mathrm{Cu}$ & $\mathrm{Fe}$ & $\mathrm{Mn}$ & $\mathrm{Zn}$ \\
\hline 1 & 43.50 & 1.97 & 16.05 & 38.41 & 5.92 & 8.03 & 20.25 & 73.30 & 168.28 & 91.56 & 38.17 \\
2 & 44.50 & 1.99 & 12.80 & 39.66 & 6.33 & 8.53 & 24.75 & 11.33 & 194.72 & 96.07 & 24.96 \\
\hline
\end{tabular}

Laboratory of Soil Chemistry, Center of Agrarian Sciences, UFSCar.

Other studies have shown results different from those found in our study. Faber et al. (2001) found that root system growth in the superficial soil layers can be favored by the presence of mulching, facilitating the absorption of nutrients such as phosphorus, which is accumulated in the superficial layers due to its low mobility. In addition, Bremer Neto et al. (2008) stated that the balance between mineralization and immobilization of soil $\mathrm{N}$ could be affected by mulching distribution in order to reduce its availability to plants and require complementary fertilization of this nutrient.

The insignificant difference in nutrient content between treatments may be due to the short duration of the experiment. In the study of Mendonça et al. (2019), for example, notice that 110 days is a short time to observe soil salinization due to the fertigation in the tomato crop.

\section{CONCLUSIONS}

The use of organic mulching did not interfere with cabbage productivity under greenhouse conditions. The straw increases the efficiency of irrigation since it reduces soil evaporation, and consequently increases water-use effectiveness. The soil cover made it possible to save up to $28.1 \mathrm{~mm}(14.5 \%)$ of water depth.

\section{ACKNOWLEDGMENTS}

The authors gratefully acknowledge São Paulo Research Foundation (FAPESP) for the financial support (Project No. 2014/21222-4).

\section{REFERENCES}

ANA (Brasil). Conjuntura dos recursos hídricos no Brasil 2017: relatório pleno/Agência Nacional de Águas. Brasília, 2017. 169 p.

ANDRADE, M. G.; VILAS BOAS, M. A.; SIQUEIRA, J. A. C.; DIETERA, J.; SATO, M.; HERMES, E.; MERCANTE, E.; TOKURA, L.K. Statistical quality control for the evaluation of the uniformity of micro sprinkler irrigation with photovoltaic solar energy. Renewable and Sustainable Energy Reviews, v.78, n.1, p.743-753, 2017. https://doi.org/10.1016/j.rser.2017.05.012

BIZARI, D. R.; GRECCO, K. L.; SOUZA, C. F. Bulbo molhado estimado pela técnica da TDR na irrigação por gotejamento subsuperficial. Revista Brasileira de Agricultura Irrigada, v. 10, n. 2, p. 477-485, 2016. https://dx.doi.org/10.7127/RBAI.V10N200352

BONINI, M. A.; SATO, L. M.; BASTOS, R. G.; SOUZA, C. F. Alterações nos atributos químico e físicos de um Latossolo vermelho irrigado com água residuária e vinhaça. Revista Biociências, v. 20, n. 1, p. 56-63, 2014. 
BREMER NETO, H.; VICTORIA FILHO, R.; MOURÃO FILHO, F. A. A.; MENEZES, G. M.; CANALI, E. Estado nutricional e produção de laranjeira 'Pêra' em função da vegetação intercalar e cobertura morta. Pesquisa Agropecuária Brasileira, v. 43, n. 1, p. 29-35, 2008.

CORTEZ, J. W.; NAGAHAMA, H. J.; OLSZEVSKI, N.; PATROCINIO FILHO, A. P.; SOUZA, E. B. Umidade e temperatura de Argissolo amarelo em sistemas de preparo e estádios de desenvolvimento do milho. Engenharia Agrícola, v. 35, n. 4, p. 699-710, 2015. http://dx.doi.org/10.1590/1809-4430-Eng.Agric.v35n4p699-710/2015

EMBRAPA. Manual de métodos de análise de solo. Rio de Janeiro: Embrapa Solos, 2011. $230 \mathrm{p}$.

FABER, B. A.; DOWNER, A. J.; MENGE, J. A. Differential effects of mulch on citrus and avocado. Acta Horticulturae, v. 557, p. 303-308, 2001. https://doi.org/10.17660/ActaHortic.2001.557.39

FERREIRA, N. M.; MESQUITA, E. F.; SÁ, F. V. S.; BERTINO, A. M. P.; PAIVA, E. P.; FARIAS, S. A. R. Crescimento e produção da mamoneira BRS Paraguaçu sob irrigação, cobertura do solo e adubação orgânica. Revista Brasileira de Engenharia Agrícola e Ambiental, v. 19, n. 9, p. 857-864, 2015. http://dx.doi.org/10.1590/18071929/agriambi.v19n9p857-864

FREITAS, P. L.; LANDERS, J. N. The transformation of agriculture in Brazil through development and adoption of zero tillage conservation agriculture. International Soil and Water Conservation Research, v. 2, n. 1, p. 35-46, 2014. https://doi.org/10.1016/S2095-6339(15)30012-5

MEDRANO, H.; TOMÁS, M.; MARTORELL, S.; ESCALONA, J.M.; POU, A.; FUENTES, S.; FLEXAS, J.; BOTA, J. Improving water use efficiency of vineyards in semi-arid regions. A review. Agronomy for Sustainable Development, v. 35, n. 2, p. 499-517, 2015. https://doi.org/10.1007/s13593-014-0280-z

MENDONÇA, T. G.; BERÇA, A. S.; SOUZA, C. F. Uso da água em tomateiro cultivado com cobertura morta em casa de vegetação. Revista Brasileira de Agricultura Irrigada, v. 13, n. 1, p. 3236-3246, 2019. https://dx.doi.org/10.7127/rbai.v13n1001008

MORAES, P. V. D.; AGOSTINETTO, D.; PANOZZO, L. E.; OLIVEIRA, C.; VIGNOLO, G. K.; MARKUS, C. Manejo de plantas de cobertura no controle de plantas daninhas e desempenho produtivo da cultura do milho. Semina: Ciências Agrárias, v. 34, n. 2, p. 497-507, 2013.

MOURA, E. G.; REZENDE, K. D. A.; ARAUJO, J. C.; CASTRO, M. F. Efeito de métodos de irrigação e do uso de cobertura vegetal sobre o cultivo de repolho em São Luís - MA.

Horticultura Brasileira, v. 24, n. 4, p. 410-413, 2006.

MURGA-ORRILlO, H.; ARAUJO, W. F.; RODRIGUEZ, C. A.; LOZANO, R. M. B.; SAKAZAKI, R. T.; VARGAS, A. R. P. Influência da cobertura morta na evapotranspiração, coeficiente de cultivo e eficiência de uso de água do milho cultivado em cerrado. Irriga, v. 21, n. 2, p. $352-364, \quad 2016$. https://doi.org/10.15809/irriga.2016v21n2p352-364

PEREIRA, A. L.; MOREIRA, J. A. A.; KLAR, A. E. Efeito de níveis de cobertura do solo sobre o manejo da irrigação do feijoeiro (Phaseolus vulgaris L.). Irriga, v. 7, n. 1, p. 42-52, 2002. 
R CORE TEAM. R: A language and environment for statistical computing. Vienna, 2015.

RAIJ, B. Van; CANTARELLA, H.; QUAGGIO, J.A.; FURLANI, A. M. C. Recomendações de adubação e calagem para o Estado de São Paulo. Campinas: Fundação IAC, 1997. $285 \mathrm{p}$.

SANTORO, B. L.; PIRES, R. C. M.; PERES, J. G.; SOUZA, C. F. Soil solution dynamics for drip fertigation management in bell pepper crop. Irriga, v. 1, n. 1, p. 96-112, 2016. https://dx.doi.org/10.15809/irriga.2016v1n01p99-112

SANTOS, H. G.; JACOMINE, P. K. T.; ANJOS, L. H. C.; OLIVEIRA, V. A.; LUMBRERAS, J. F.; COELHO, M. R.; ALMEIDA, J. A.; CUNHA, T. J. F.; OLIVEIRA, J. B. Sistema Brasileiro de Classificação de Solos. Brasília: Embrapa, 2013. 306 p.

SILVA, T. O.; FURTINI NETO, A. E.; CARNEIRO, L. F.; PALUDO, V. Plantas de cobertura submetidas a diferentes fontes de fósforo em solos distintos. Semina: Ciências Agrárias, v. 32, n. 4, p. 1315-1326, 2011.

SILVA JÚNIOR, A. A. Repolho: fisiologia, fitotecnia, tecnologia alimentar e mercadologia. Florianópolis: EMPASC, 1989. 295 p.

SOUZA, C. F.; FAEZ, R.; BACALHAU, F. B.; BACARIN, M. F.; PEREIRA, T. S. In situ monitoring of a controlled release of fertilizers in lettuce crop. Engenharia Agrícola, v. 37, n. 4, p. 656-664, 2017. http://dx.doi.org/10.1590/1809-4430-eng.agric.v37n4p656$664 / 2017$

STONE, L. F.; MOREIRA, J. A. A. Efeitos de sistemas de preparo do solo no uso da água e na produtividade do feijoeiro. Pesquisa Agropecuária Brasileira, v. 35, n. 4, p. 835-841, 2000 .

URBANO, V. R.; MENDONÇA, T. G.; BASTOS, R. G.; SOUZA, C. F. Effects of treated wastewater irrigation on soil properties and lettuce yield. Agricultural Water $\begin{array}{lllllll}\text { Management, } & \text { v. } & 181, & \text { n. } & 1, & \text { p. } & 108-115,\end{array}$ https://doi.org/10.1016/j.agwat.2016.12.001 


Ambiente \& Água - An Interdisciplinary Journal of Applied Science
ISSN 1980-993X - doi:10.4136/1980-993X
www.ambi-agua.net
E-mail: ambi.agua@gmail.com

\title{
Water quality in Ponte Pensa Aquaculture Park, Solteira Island Reservoir, SP, Brazil, where fish are cultivated under great-volume cage system
}

\author{
ARTICLES doi:10.4136/ambi-agua.2382
}

Received: 22 Feb. 2019; Accepted: 26 May 2019

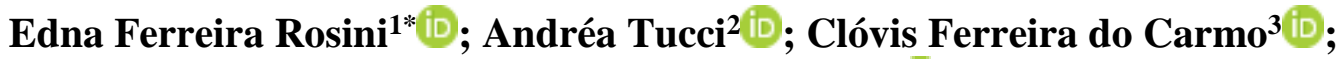 \\ Helenice Pereira de Barros 4 \\ ${ }^{1}$ Universidade Guarulhos (UNG), Guarulhos, SP, Brasil \\ Centro de Pós-graduação e Pesquisa. E-mail: edna.ferreira@prof.ung.br \\ ${ }^{2}$ Instituto de Botânica (IBOT), São Paulo, SP, Brasil \\ Núcleo de Pesquisa em Ficologia. E-mail: atuccic@gmail.com \\ ${ }^{3}$ Instituto de Pesca (IP), São Paulo, SP, Brasil \\ Centro de Recursos Hídricos. E-mail: clovis@ pesca.sp.gov.br \\ ${ }^{4}$ Instituto de Pesca (IP), São José do Rio Preto, SP, Brasil \\ Centro de Pesquisa do Pescado Continental. E-mail: helenicebarros@pesca.sp.gov.br \\ *Corresponding author
}

\begin{abstract}
This study analyzes spatial and temporal variations in physical and chemical water variables due to the influence of fish culture in a cage system $(20 \times 20 \times 3 \mathrm{~m})$ in Ponte Pensa Aquaculture Park (Solteira Island Reservoir), before and after cage installation. Water samples were collected on a monthly basis in the subsurface of three sampling sites (August/2011 to July/2013): downstream from the farming site (S1), at the farming site (S2), and upstream from the farming site $(\mathrm{S} 3)(\mathrm{n}=72)$. Water temperature, $\mathrm{pH}$, dissolved oxygen, transparency, turbidity, electrical conductivity, ammonium ion and total phosphorus were assessed. The principal component analysis (PCA) was applied to joint analysis data. PCA results explained the $61 \%$ joint variability in data of the first two components. Fish farming in cages caused significant temporal changes, mainly in January 2013, as well as sudden spatial changes in water physical and chemical variables. Fish culture influenced the quality of the water; such influence was mainly indicated by variations in ammonium ions and in total phosphorus concentrations, which were confirmed through PCA application. PCA results showed two distinct temporal phases: Phase 1 - prior to fish-cage farming, when limnological conditions were characterized by the highest dissolved oxygen concentrations and by high temperatures; Phase 2 - post-production period, when limnological conditions were characterized by the highest total phosphorus and ammonium ion concentrations.
\end{abstract}

Keywords: ammonium ion, fish farming in cages, total phosphorus. 
Edna Ferreira Rosini et al.

\section{Influência da piscicultura em tanques-redes de grande volume na qualidade da água do Parque Aquícola Ponte Pensa, Reservatório Ilha Solteira, SP, Brasil}

\section{RESUMO}

O objetivo do presente estudo é analisar a variação espacial e temporal das variáveis físicas e químicas da água na zona de influência da tilapicultura em tanques-redes (20x20x3 m) no parque aquícola Ponte Pensa (Reservatório de Ilha Solteira), abrangendo os períodos pré e pósintrodução da produção. Amostras da água foram obtidas mensalmente (agosto/2011 a julho/2013) na subsuperfície em três estações de amostragem: jusante da área de criação (S1), local de criação $(\mathrm{S} 2)$ e a montante $(\mathrm{S} 3)(\mathrm{n}=72)$. Foram avaliadas a temperatura da água, $\mathrm{pH}$, oxigênio dissolvido, transparência, turbidez, condutividade elétrica, íon amônio e fósforo total. Utilizou-se a PCA para análise conjunta dos dados. A PCA explicou $61 \%$ da variabilidade conjunta dos dados nos dois primeiros componentes. As atividades da piscicultura em tanquesrede provocaram alterações temporais, detectadas especialmente a partir de janeiro de 2013, e sutis alterações espaciais nas variáveis físicas e química da água. O íon amônio e o fósforo total foram as variáveis que mais indicaram a influência desta atividade na qualidade da água, confirmados pela PCA que demostrou duas fases temporais distintas: Fase 1- em que as condições limnológicas antes da produção de peixes em tanques-rede foram caracterizadas pelas maiores concentrações de oxigênio dissolvido e altas temperaturas; e Fase 2 - período pós-produção, que foi caracterizada pelas concentrações mais elevadas de fósforo total e íon amônio.

Palavras-chave: fósforo total, íon amônio, piscicultura.

\section{INTRODUCTION}

The global population is estimated to reach 9.7 billion people by 2050 , and this population growth has increased the yearly demand for food. This scenario is pushing basic production sectors to increase productivity and to expand their production sites (FAO, 2014). Aquaculture is one of the fastest growing activities in the food industry worldwide; it reached the historical record of 90.4 million tons in 2012, and fish farming in cage systems accounted for 66.6 million tons of this total (FAO, 2014).

According to the Brazilian Institute of Geography and Statistics (IBGE), fish farming in continental waters in the country totaled $507.12 \mathrm{t}$ in 2016 ; it increased by $4.4 \%$ in comparison to the total fish production in 2015 (IBGE, 2016). The farming of tilápias increased by $9.3 \%$ in the same period (239.09 milt, in 2016). São Paulo State ranked third among domestic producers at 48.35 t, a $47.5 \%$ increase in comparison to the previous year. Santa Fé do Sul, Northwestern São Paulo State, ranked first in the national ranking of counties, with $5.360 \mathrm{t}$ (IBGE, 2016; Barroso et al., 2018). This production growth resulted from the expansion of projects focused on assembling cages for fish farming in aquaculture parks installed in mid- and large-sized hydroelectric power-plant reservoirs (Mallasen et al., 2012).

An aquaculture parks is defined as a continuous physical space within a delimited water medium, which covers a set of similar water sites whose intermediate physical spaces allow the development of other activities along with aquaculture practices. In their turn, aquaculture sites are continuous physical spaces in delimited water media used for aquaculture (Brasil, 2003).

The first aquaculture parks to become operational were located in Itaipu (PR), Castanhao (CE), Solteira Island (MS, MG and SP), Furnas (MG), Tres Marias (MG) and Tucurui (PA) reservoirs. These six reservoirs rely on 42 aquaculture parks that together comprise 28,500 
hectares of water, whose production capacity is able to supply approximately 269 thousand tons of fish per year to the market (Araújo, 2016).

Nowadays, there are aquaculture parks operating in reservoirs all around the country; 15 sites in Solteira Island Reservoir were categorized as appropriate for aquaculture park implementation, among them, Ponte Pensa Aquaculture park, whose support capacity is to 4.59 t/year (David et al., 2015). Ponte Pensa Aquaculture Park, as well as other ones, were implemented in Brazilian reservoirs based on studies that have taken into account some environmental, sustainable, social and economic aspects. Results in these studies have pointed out good water quality conditions for aquaculture in cage system in these sites (Bueno et al., 2008; David et al., 2015).

Fish farming in cage systems is an intensive production modality, but it has high potential to cause environmental impact, since feed waste and fish excreta are released into the aquatic environment. These discharges increase nitrogen and phosphorus concentrations in the water and lead to artificial eutrophication processes (Guo and Li, 2003; Alves and Baccarin, 2005; Bueno et al., 2008; Guo et al., 2009; Mallasen et al., 2008; 2012).

Fish cage farming influence on water limnological characteristics depends on fish production intensity, on waste dispersion, on the quality of the feed and on the assimilation ability of the environment where the cages are installed in (Borghetti and Ostrenky, 1999; Mallasen et al., 2012; Ayroza et al., 2013).

Some studies (Fernandes et al., 2001; Piedrahita, 2003; Borges et al., 2010, Mallasen et al., 2012) emphasize the importance of assembling cages in reservoirs presenting favorable hydrodynamic characteristics, since these features allow nutrient dispersion from the organic load in the production system and water quality disturbance assimilation in sites used for fish farming. Therefore, the definition of aquaculture parks, such as Ponte Pensa, is essential for aquaculture development planning, since farming sites are delimited based on multidisciplinary studies (morphometry, climatology and hydrodynamics.) aimed at determining hydrodynamically favorable sites for fish farming in cage systems (David et al., 2015).

Studies that have evaluated the influence of fish-cage farming on the limnological characteristics of sites where this system is operational help in better understanding the dynamics of the cage system and its relationship with the environment. Moreover, they highlight the efficiency of hydrodynamic characteristics observed in delimited sites.

The aim of the present study was to analyze spatial (horizontal) and temporal (monthly) variations in water physical and chemical variables in sites influenced by fish farming in greatvolume cage systems $\left(1,200 \mathrm{~m}^{3} ; 20 \times 20 \times 20 \mathrm{~m}\right)$, such as Solteira Island Reservoir (Ponte Pensa Aquaculture Park), before and after farming site implementation. It is worth highlighting that these great-volume cage systems have been recently installed in Brazil.

The evaluation of the environmental variability of abiotic data in relation to the (temporal) months of study and the sampling stations (spatial) was performed through principal component analysis (PCA). The PCA is a multivariate statistical technique that transforms a set of original variables into a smaller set of independent variables called principal components, which in turn retain the maximum information of the total variation contained in the data (Hongyu et al., 2015).

\section{MATERIALS AND METHODS}

The study was carried out in Fish Farm Geneseas Aquacultura Ltda, which is located in Ponte Pensa Aquaculture Park. This park holds part of Ponte Pensa River, which feeds Solteira Island hydroelectric power plant reservoir, SP, Brazil (Figure 1). The location and characteristics of Solteria Island Reservoir and of Ponte Pensa Aquaculture Park were addressed by Rosini et al. (2016). 


\subsection{Climate Variables}

Rainfall and air temperature information for the period between August 2011 and July 2013 in the assessed region was provided by the Integrated Center for Agrometeorological Information (CIIAGRO) of the Department of Agriculture and Supply of São Paulo State.

\subsection{Sample collection and collection period}

Sample collection started in August 2011, five months before cage system of fish farming was operational. The first cages were installed in Jan/Feb 2012; there were two modules of eight large cages $\left(1,200 \mathrm{~m}^{3} ; 20 \times 20 \times 3 \mathrm{~m}\right)$ in the site at the end of the experimental period.

A "van Dorn" collecting bottle was used to collect water samples on a monthly basis from the subsurface of sites impacted by fish-cage farming for two years (August 2011 to July 2013) $(n=72)$. The samples were used in the analysis applied to find the limnological conditions (total phosphorus $\left(\mu \mathrm{g} \mathrm{L}^{-1}\right)$ and the ammonium ion concentration $\left(\mu \mathrm{g} \mathrm{L}^{-1}\right)$. Three sampling sites were evaluated: S1 (750 m upstream from the site with the cages downstream in the Ponte Pensa River, coordinates $20^{\circ} 16^{\prime} 134^{\prime \prime} \mathrm{S}$ and $50^{\circ} 59^{\prime} 107^{\prime \prime} \mathrm{W}$, mean depth $30 \mathrm{~m}$ ), S2 (the farming site, coordinates $20^{\circ} 16^{\prime} 452^{\prime \prime} \mathrm{S}$ and $50^{\circ} 58^{\prime} 812^{\prime \prime} \mathrm{W}$; mean depth $27 \mathrm{~m}$ ), and S3 (650 m downstream from the site with cages upstream in the Ponte Pensa River, coordinates $20^{\circ} 16^{\prime} 853^{\prime \prime} \mathrm{S}$ and $50^{\circ} 58^{\prime} 980^{\prime \prime} \mathrm{W}$, mean depth $26 \mathrm{~m}$ ) (Figure 1). Sampling sites were delimited with GPSMAP 76CS / Garmin.

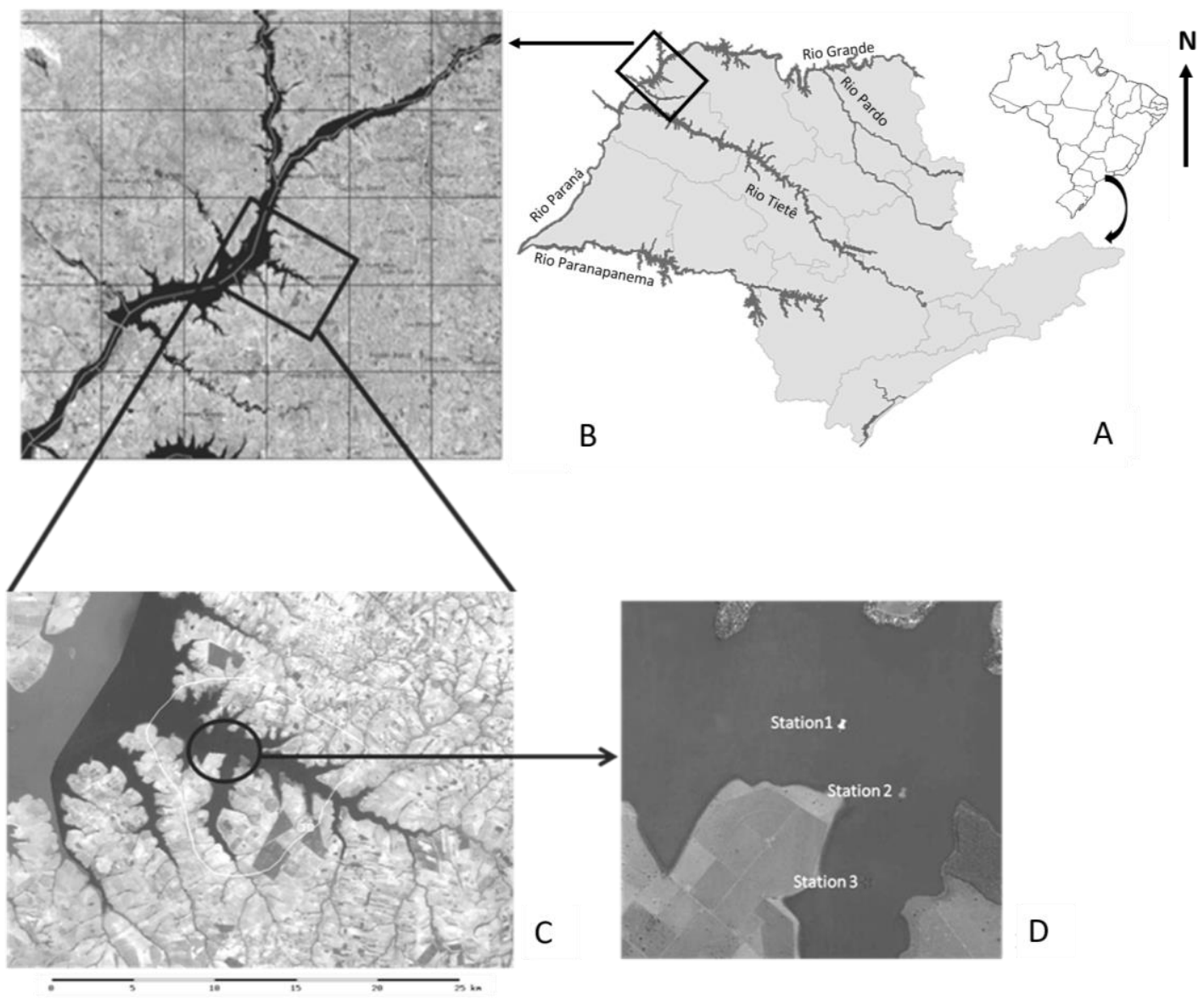

Figure 1. (A) The arrow indicates the location of Solteira Island Reservoir in São Paulo State, Brazil. (B) The rectangle indicates the location of the Ponte Pensa River arm in the Solteira Island Reservoir. (C) Geneseas fish-cage farming site $\left(20^{\circ} 17^{\prime} \mathrm{S}\right.$ and $\left.50^{\circ} 58^{\prime} \mathrm{W}\right)$ is delimited by the dark line and the Ponte Pensa River arm is marked by the light line. (D) Location of sampling sites S1, S2 and S3.

Source: Rosini et al. (2016). 


\subsection{Analysis of Water Physical and Chemical Variables}

Water temperature profile $\left({ }^{\circ} \mathrm{C}\right), \mathrm{pH}$, electrical conductivity $\left(\mu \mathrm{S} \mathrm{cm}{ }^{-1}\right)$, water turbidity (NTU) and dissolved oxygen $(\mathrm{mg} / \mathrm{L})$ values were obtained in situ with the water quality multiparameter meter YSI Professional Plus (ProPlus). Water transparency (m) was determined based on Secchi disk disappearance depth; total phosphorus $\left(\mu \mathrm{g} \mathrm{L}^{-1}\right)$ and ammonium ion $\left(\mu \mathrm{g} \mathrm{L}^{-1}\right)$ concentrations were analyzed based on Valderrama (1981) and Solorzano (1969), respectively.

The collected data were compared to values established by CONAMA Resolution N. $357 / 2005$ (CONAMA, 2005) in order to verify whether or not they remained within the limits for Class II water bodies, which include aquaculture sites.

Monthly data about the amount of consumed feed were provided by Geneseas Aquacultura Ltda to assess feed waste influence on the quality of water.

\subsection{Statistical Analysis}

Abiotic data were subjected to joint evaluation based on the principal component analysis (PCA); the analyses were carried out in the PC-ORD software, Version 4.0, for Windows (Mccune and Mefford, 2011). Data were transformed through $[\log (\mathrm{x}+1)]$.

\section{RESULTS AND DISCUSSION}

Based on rainfall and air temperature data, the assessed region counts on two specific seasons: wet summer and dry winter. The lowest rainfall values (below $10 \mathrm{~mm}$ ) were recorded in winter - August/September 2011, July/August 2012 and July 2013 -, whereas the highest values for this variable (above $214 \mathrm{~mm}$ ) were recorded in summer, January 2012 and January/March 2013 (Figure 2).

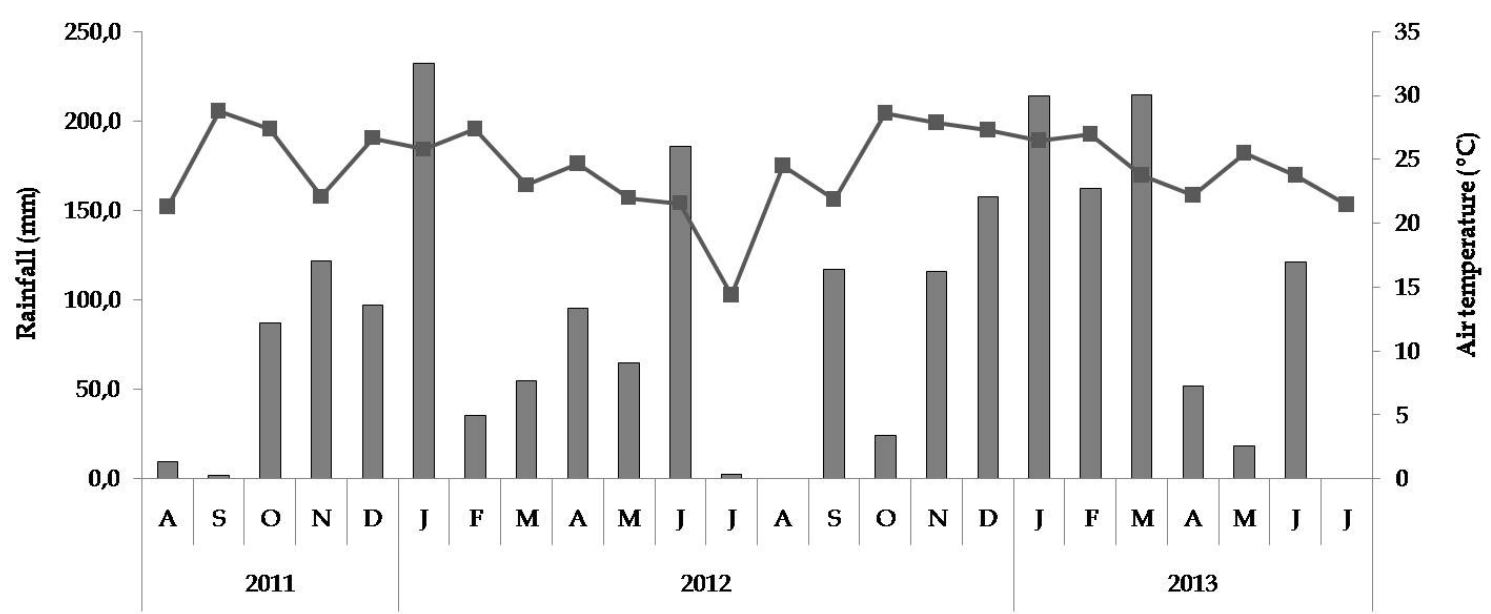

Figure 2. Mean monthly air temperature $\left({ }^{\circ} \mathrm{C}\right)$ and rainfall $(\mathrm{mm})$ variation in Santa Fé do Sul/SP during the study period.

There were no significant abiotic changes between sampling sites. Water temperature was close to $26.5^{\circ} \mathrm{C}$; the lowest temperatures were recorded in July/2012 $\left(22.6^{\circ} \mathrm{C}\right)$ and the highest in February $/ 2012\left(30.7^{\circ} \mathrm{C}\right)$ (Figure 3A).

There was a drop in dissolved oxygen (DO) values at Station 2 in February 2012, after the fish-cage farm became operational. The lowest DO concentrations were observed at this site, mainly after the second half of 2012 (Figure 3B), although the recorded values (above $4.0 \mathrm{mg} \mathrm{L}^{-1}$ ) remained in the specifications recommended for tropical fish farming (Boyd, 1990; Kubitza, 2000) and within the limit established by CONAMA Resolution N. 357/2005 for Class II water bodies, including aquaculture sites. 

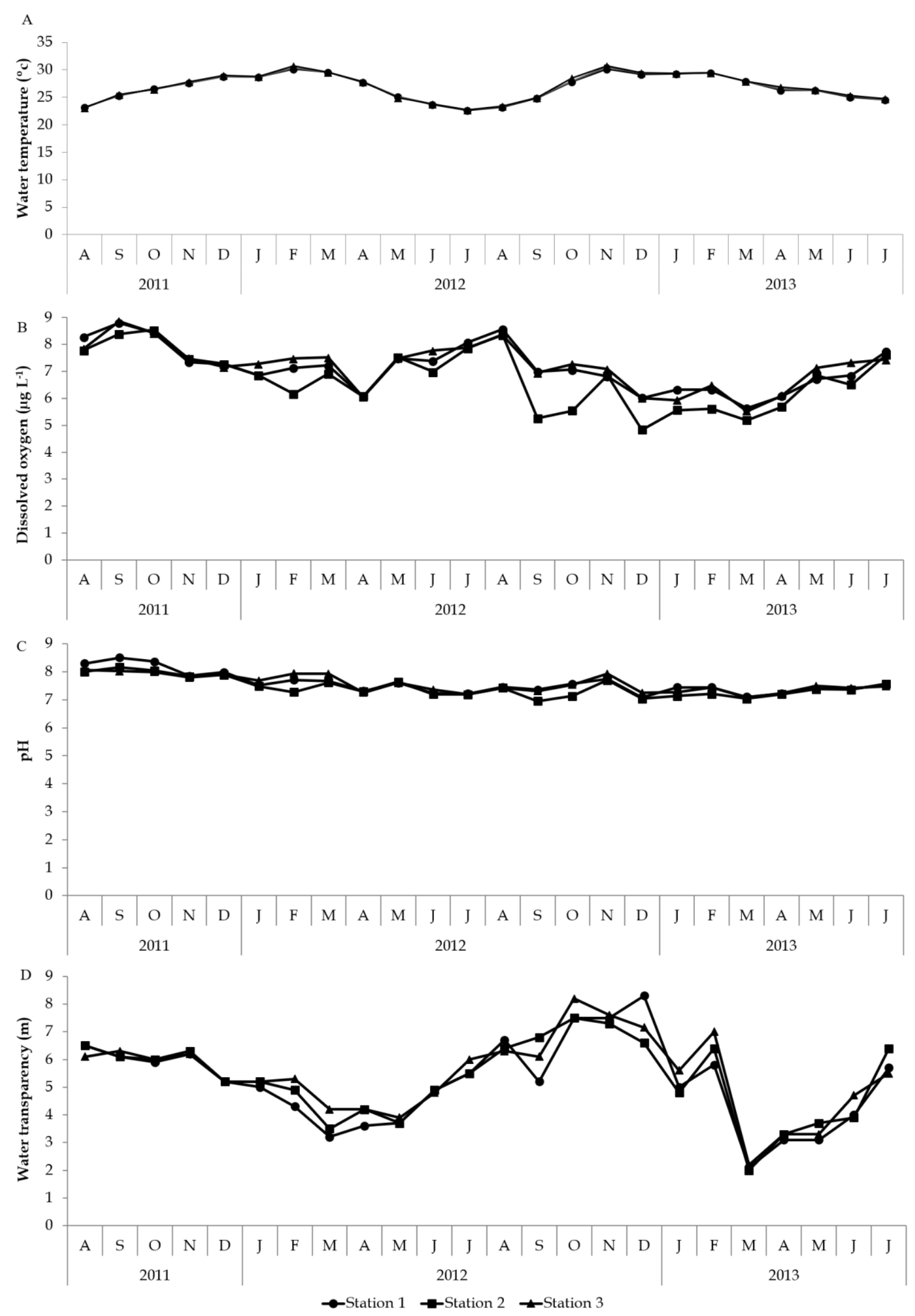

Figure 3. Temporal variation in the assessed variables - water temperature $\left({ }^{\circ} \mathrm{C}\right)(\mathrm{A})$, dissolved oxygen $\left(\mathrm{mg} \mathrm{L}^{-1}\right)(\mathrm{B}), \mathrm{pH}(\mathrm{C})$ and water transparency $(\mathrm{m})(\mathrm{D})$ - at the collection sites throughout the study period. 
According to the recorded $\mathrm{pH}$ Values, water at the site was alkaline; but these values decreased in February 2012 (Figure 3C) and became similar to the ones recorded for dissolved oxygen at Station 2. Transparency values ranged from 2.0 to $8.3 \mathrm{~m}$. There was a decrease of approximately $4.0 \mathrm{~m}$ in water transparency in March, April and May 2012 and 2013, in comparison to months analyzed before this time. Water transparency $(2.0 \mathrm{~m})$ recorded the lowest values in March 2013 at Station 2 (Figure 3D). Water turbidity varied between 1UNT and 8UNT; different from water transparency, it had significant increase in March, April, May and June 2012/2013 in comparison to the other months (Figure 4A).

Conductivity values were always lower than $55 \mu \mathrm{S} \mathrm{cm}^{-1}$; however, in May, June and July 2013, there was sudden conductivity increase in comparison to the other months (Figure 4B). Ammonium ion concentrations showed remarkable increase in the last seven collection months at the three collection sites (January to July 2013); rates reached values $100 \%$ higher than the ones recorded in previous analyses (Figure 4C). Total phosphorus concentrations also increased throughout the study period, mainly in September 2012. These concentrations were overall higher in 2013 in comparison to values recorded in the same period in 2012 (Figure 4D). Although the analyzed variables recorded little variation in the sampling sites since they became operational (February 2012), total phosphorus concentrations were higher than $30 \mu \mathrm{g} \mathrm{L} \mathrm{L}^{-1}$ at Station 2 (fish-cage farming site) (Figure 4D).

With regard to feed quality, 146 tons of feed were supplied on a monthly basis, on average; the largest amounts of it were supplied in the last months of the study period (May, June and July 2013) (Figure 4E).

Principal component analysis (PCA) explained the 61\% joint variability in data of the first two components; this outcome indicated seasonality as the factor coordinating the abiotic changes between August 2011 and December 2012. All sampling units in 2011 and most units in 2012 were on the negative side of axis 1 , which is associated with the highest dissolved oxygen $(\mathrm{DO})(\mathrm{r}=0.8)$ and $\mathrm{pH}(\mathrm{pH}=0.6)$ values (Figure 5). On the other hand, all sampling units in 2013 were grouped on the positive side of axis 1, which is associated with the highest ammonium ion (NH4) $(r=0.8)$ and total phosphorus (TP) $(r=0.5)$ concentrations. The highest turbidity (Turb) $(r=0.6)$ values were associated with the highest conductivity (Cond) $(r=0.4)$ values, although at a low correlation (Figure 5). Sampling units in January, February, March, October, November and December 2012 were grouped on the positive side of axis 2, which is associated with the highest water temperatures $(r=0.8)$ (Figure 5).

Based on PCA records, there were two distinct time phases: Phase 1 - when limnological conditions before the fish cage farm was operational (August and December 2011) were characterized by the highest dissolved oxygen concentrations; Phase 2 - post-production period (January to July 2013), which was characterized by the highest total phosphorus and ammonium ion concentrations and by high conductivity and turbidity values (Figure 5). The first and the last quarter of 2012 were associated with the highest temperatures.

According to PCA results, the analyzed abiotic variables were influenced by seasonality. Other authors also pointed out seasonality as one of the factors influencing variations in abiotic factors, mainly water transparency, in studies similar to the current one (Alves and Baccarin, 2005; Borges et al., 2010; Kaggwa et al., 2011; Ayroza et al., 2013; Bartozek et al., 2014).

Although water transparency values were similar in all sites sampled in March, April and May 2012 and 2013, this variable recorded $4.0 \mathrm{~m}$ decrease in comparison to the other months in the same time period. Such decrease was not directly related to phytoplankton density increase, since phytoplankton densities were always very low during the whole period (lower than 1,933 org $\mathrm{mL}^{-1}$, as recorded by Rosini et al. (2016)). Summer rainfall has likely influenced transparency by transporting allochthonous material through runoff, a fact that makes water more turbid due to the suspended material. 

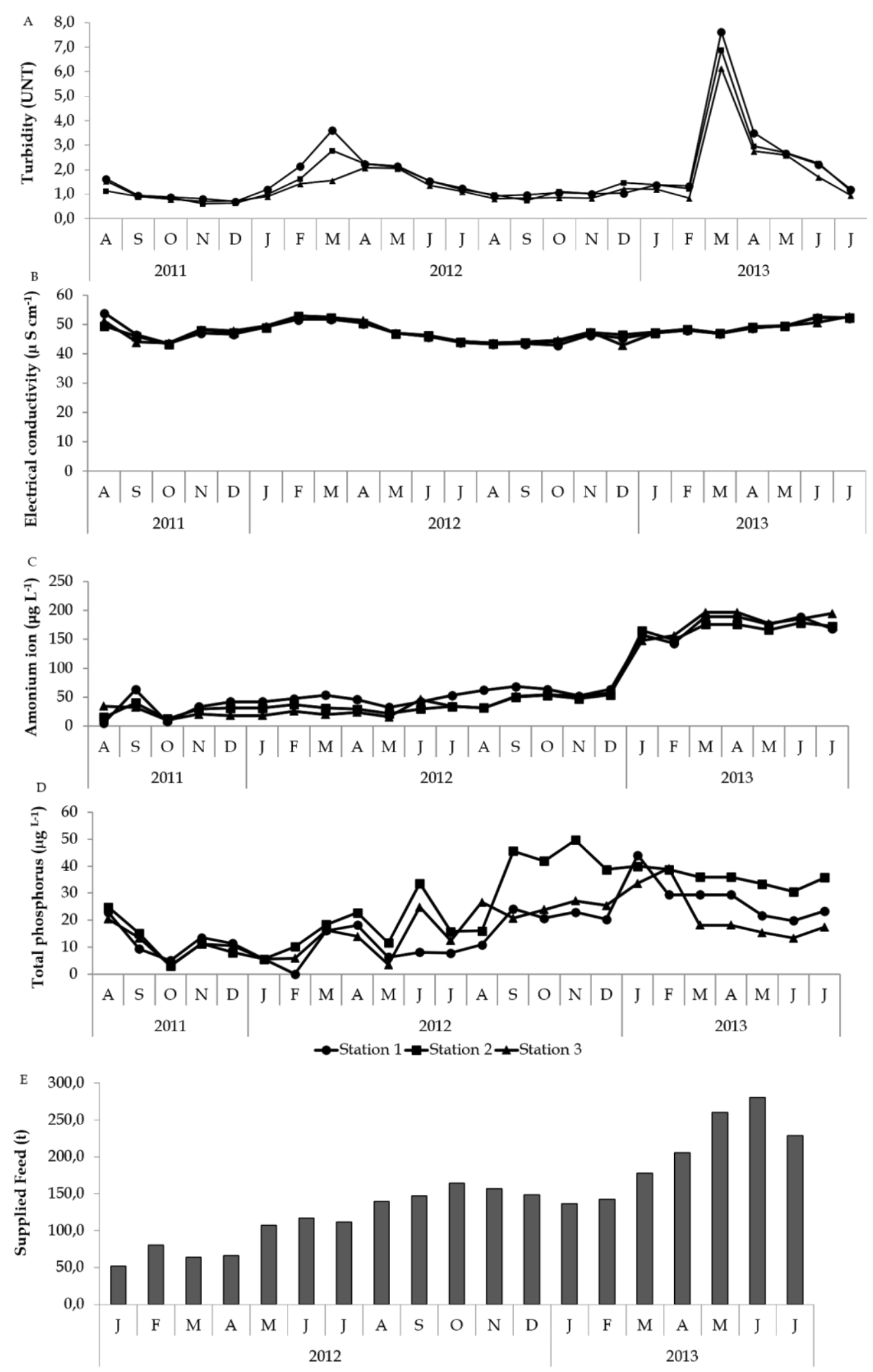

Figure 4. Temporal variation in the assessed variables - turbidity (UNT) (A), electrical conductivity $\left(\mu \mathrm{S} \mathrm{cm}^{-1}\right)(\mathrm{B})$, ammonium ion concentrations $\left(\mu \mathrm{g} \mathrm{L}^{-1}\right)(\mathrm{C})$ and total phosphorus ( $\mu \mathrm{g} \mathrm{L}^{-1}$ ) (D) - at the collection sites during the study period; (E) Tons (t) of feed supplied to the cages in Geneseas Aquacultura, during the study period. 


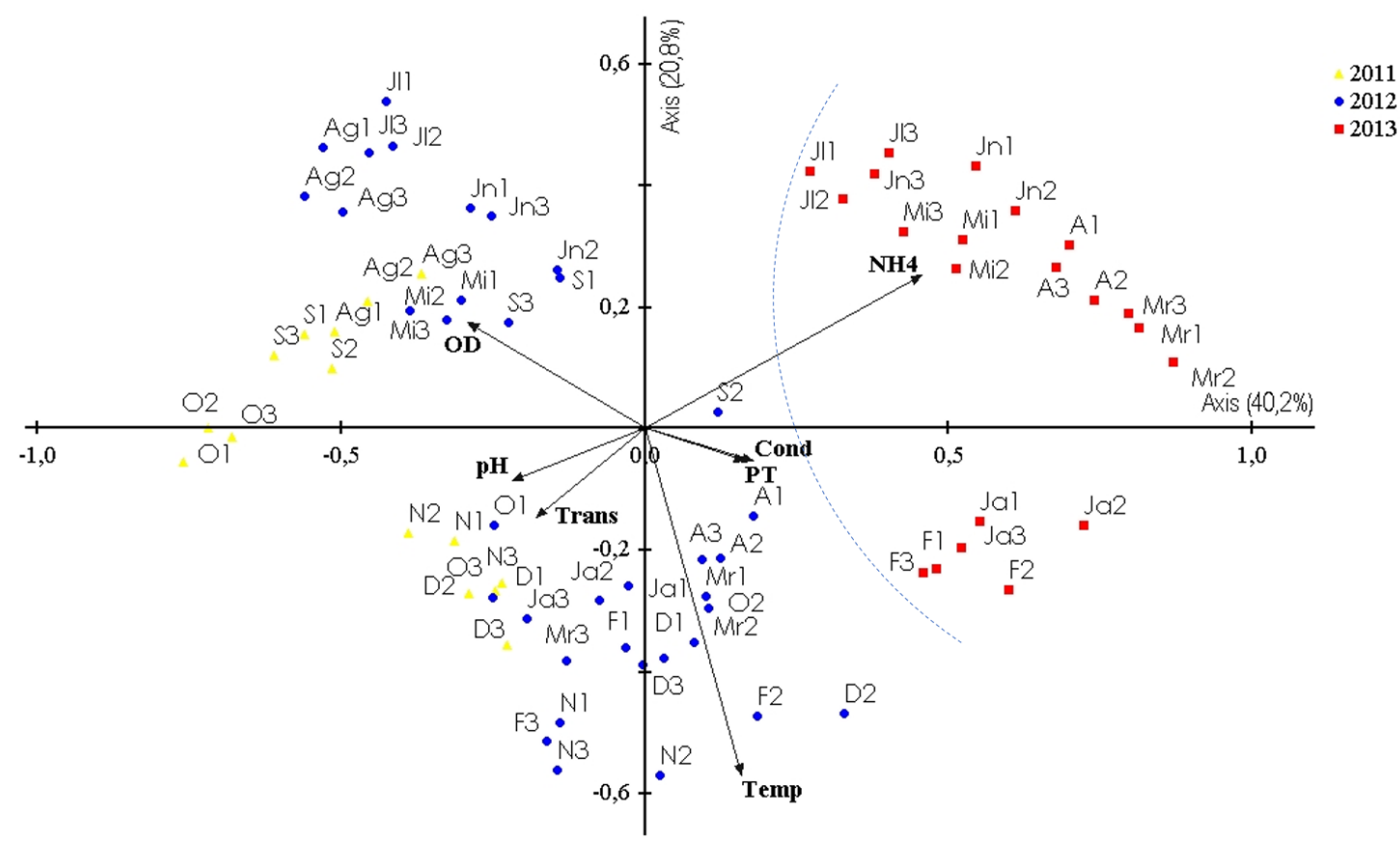

Figure 5. Principal components analysis (PCA) based on seven limnological variables of 72 sampling units (temporal and spatial). Abiotic variables: temperature (Temp), dissolved oxygen (DO), electrical conductivity (Cond), turbidity (Turb), $\mathrm{pH}$, total phosphorus (TP) and ammonium ion $\left(\mathrm{NH}_{4}\right)$. Sampling units were identified based on collection year $(\Delta=2011$, $\circ=2012$, $\square=2013$ ), month (Ja: January, F: February, Mr: March, A: April, My: May, Jn: June, Jl: July, Aug: August, S: September, O: October, N: November, D: December) and sampling site (Station $1=1$, Station $2=2$ and Station $3=3$ ).

Although rainfall influence on transparency should be taken into consideration, fish-cage farming influence should not be ruled out, since there was a decrease in transparency in the last months of the study period (March to June 2013) in comparison to transparency values recorded in the same months in 2012. Despite the high rainfall values observed in February and March 2013, the amount of consumed feed almost doubled in the same months of 2012; this outcome may have contributed to increase the concentration of suspended solids, both due to feed residue and to increased volume of fish feces. These results corroborate Ayroza et al. (2013), who recorded higher concentrations of total dissolved solids, high turbidity values and lower water transparency as the amount of feed supplied to fish farms working under cage systems increased.

Dissolved oxygen values were similar to the ones recorded by Mallasen et al. (2012) in the same study site chosen for the present research and by Américo et al. (2013), who conducted their research in the São Jose dos Dourados River, an area influenced by cages assembled in the Solteira Island Reservoir. Dissolved oxygen values were higher than those recommended for tropical fish farming (4 mg L ${ }^{-1}$ ) (Boyd, 1990; Kubitza, 2000) and within the limit established by CONAMA Resolution N. 357/2005 for Class II water bodies, including aquaculture sites. After the introduction of the first cages in the farming sites in February 2012, DO values dropped at Station 2, which was used for fish farming. Several studies (Demir et al., 2001; Veenstra et al., 2003; Alves and Baccarin, 2005; Bristow et al., 2008; Degefu et al., 2011; Kaggwa et al., 2011; Ayroza et al., 2013) have already recorded DO concentration reduction in cage farming sites.

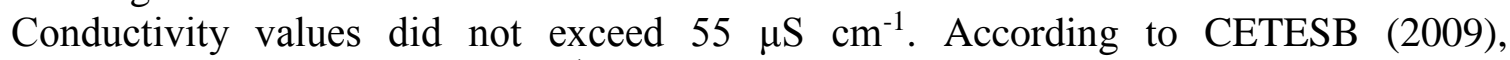
conductivity values above $100 \mu \mathrm{S} \mathrm{cm}^{-1}$ indicate impacted environments; therefore, the hereinassessed environment was not characterized as impacted during the study period.

Similar to the study by Minello et al. (2010), electrical conductivity values tended to 
increase during the rainy season, different from what was observed by Alves and Baccarin (2005). Some authors argue that rainfall has a diluting effect, and such dilution could decrease the electrical conductivity values (Alves and Baccarin, 2005; Crossetti and Bicudo, 2005). However, the input of a larger volume of water can increase the amount of dissolved solids transported to the reservoirs through the leaching process; that is likely why higher DO values were recorded in the rainy season. Although there was seasonal influence on electrical conductivity, there was fish-cage farming influence, mainly in the last three months of the study (May to July 2013). The increased conductivity recorded in 2013 in comparison to the same period in 2012 may have happened due to increased ammonium ion concentrations. Higher ammonium ion concentrations can be related to the larger volumes of fish feces and excreta in the water, which result from the installation of new cages and, consequently, from increased fish density in the study site, and from greater feed supply.

Feed waste and fish excreta decompose into ammonium, and total ammonium results from ionized ammonium $\left(\mathrm{NH}_{4}{ }^{+}\right.$) and from non-ionized ammonium $\mathrm{NH}_{3}$ (Rojas and Sanches, 2006). The presence of dissolved ammonium ions $\left(\mathrm{NH}_{4}{ }^{+}\right)$mainly depends on $\mathrm{pH}$; when $\mathrm{pH}$ is close to 7, or neutral, ammonium is in its ionized form $\left(\mathrm{NH}_{4}{ }^{+}\right)$; when $\mathrm{pH}$ is close to 9.5, approximately $50 \%$ of the ammonium in the water is in the $\mathrm{NH}_{3}$ form, and $50 \%$ of it is in the $\mathrm{NH}_{4}{ }^{+}$form; when $\mathrm{pH}$ is higher than 11, ammonium is in its non-ionized form $\left(\mathrm{NH}_{3}\right)$, which is a toxic form for fish and other living things (Koren et al., 2000).

Based on the recorded $\mathrm{pH}$ values, ammoniacal nitrogen was within the appropriate range to keep the balance between $\mathrm{NH}_{4}{ }^{+}$and $\mathrm{NH}_{3}$ fractions, with prevalence of the ionized form $\left(\mathrm{NH}_{4}{ }^{+}\right)$.

Ammoniacal nitrogen concentrations were below the value recommended for fish production - $0.6 \mathrm{mg} \mathrm{L}^{-1}$ - (Boyd, 1990); however, there was a gradual increase in the concentration of ammonium ions one year after the cages were installed. There was more than $100 \%$ increase in comparison to values recorded for previous months, probably due to the increased ammonium excretion by the fish (feces and urine). The increased amount of feed supplied in the last months of the study confirmed this information and corroborated the hereinrecorded results. Villarreal and Torres (2011) and Fu-Guang et al. (2009) reported that $60 \%$ to $80 \%$ of the total nitrogen excreted corresponds to ammonium.

The increased organic matter, nitrogen and phosphorus concentrations in the water are some of the main aspects to be taken into consideration in fish-cage farming, mainly because of the feed fish do not ingest, and because of fish feces and urine (Guo and Li, 2003; Mercante et al., 2004; Alves and Baccarin, 2005; Guo et al., 2009; Américo et al., 2013). Accordingly, increased total phosphorus concentrations in the water are a major issue and has been documented by several studies carried out in sites used for fish-cage farming (Guo and Li, 2003; Alves and Baccarin, 2005; Bristow et al., 2008; Bueno et al., 2008; Guo et al., 2009; Mallasen et al., 2012). The results recorded here corroborate the aforementioned studies, since there was a gradual increase in total phosphorus concentrations after the fish farm in cage system was operational. The highest phosphorus concentrations were recorded in Station 2, which showed values higher than the ones established by CONAMA Resolution 357 for water used for aquaculture $\left(30 \mu \mathrm{g} \mathrm{L}^{-1}\right)$, thus indicating the remarkable influence of aquaculture activities on the quality of the water.

Results confirmed by PCA showed that ammonium ions, total phosphorus, turbidity and electrical conductivity were the cage-farming variables having the strongest influence on the quality of the water in Ponte Pensa Aquaculture Park. Based on this outcome, the highest ammonium ion and total phosphorus concentrations, and electrical conductivity were observed in the last seven months of the study, when there was increased feed supply (farming intensification). These values suggest increased fish production and, consequently, increased feed waste, as well as larger volumes of feces and excreta.

Rev. Ambient. Água vol. 14 n. 4, e2382 - Taubaté 2019 


\section{CONCLUSIONS}

Fish farming in cage systems located in Ponte Pensa Aquaculture Park, Solteira Island Reservoir, Santa Fe do Sul County, Brazil, caused significant temporal and sudden spatial changes in water physical and chemical variables. Ammonium ion and total phosphorus concentrations increased over time, mainly at fish-cage farming sites.

Short residence time (21.6 days) and flow rate $\left(172 \mathrm{~m}^{3} \mathrm{~s}^{-1}\right)$ likely allowed exporting nutrients downstream (Paraná River) and improved the capacity of the environment to assimilate disturbances in the quality of the water caused by the production process. Along with fish-cage farming management, these variables were decisive to mitigate the impact of fish feed and metabolism organic load on the studied aquatic system and on the spatial similarity between sampling sites.

\section{ACKNOWLEDGEMENT}

The authors are grateful to CAPES (Coordenacão de Aperfeiçoamento de Pessoal de Nível Superior) for granting the doctorate scholarship to the first author, E.F.R.; to FAPESP (Fundação de Amparo à Pesquisa do Estado de São Paulo) process number 11/03485-0, for funding the project; and to GeneSeas company for the logistic support.

\section{REFERENCES}

AMÉRICO, J. H. P.; PREVIATO, V.; CARVALHO, S. L. Qualidade da água de uma piscicultura em tanques-rede no rio São José dos Dourados, Ilha Solteira - São Paulo. Periódico Eletrônico Fórum Ambiental da Alta Paulista, v. 9, n. 2, P. 69-77, 2013. https://dx.doi.org/10.17271/19800827922013631

ALVES, R. C. P.; BACCARIN, A. E. Efeito da produção de peixes em tanques-rede sobre sedimentação de material em suspensão e de nutrientes no córrego do Arribada (UHE Nova Avanhandava, Baixo Rio Tietê, SP). In: NOGUEIRA, M. G.; HENRY, R.; JORCIN, A. (Eds.). Ecologia de reservatórios: impactos potenciais, ações de manejo e sistemas em cascata. São Carlos: Rima, 2005. p. 329-347.

ARAÚJO, E. A. D. Políticas públicas para sustentabilidade: o caso do projeto Ipirá na usina hidrelétrica de Tucuruí-Pa. REGE - Revista de Gestão, v. 23, n. 4, 276-285. 2016. https://dx.doi.org/10.1016/j.rege.2016.09.004

AYROZA, D. M. M. R.; NOGUEIRA, M. G.; AYROZA, L. M. S.; CARVALHO, E. D.; FERRAUDO, A. S.; CAMARGO, A. F. M. Temporal and spatial variability of limnological characteristics in áreas under the influence of tilápia cages in the Chavantes Reservoir, Paranapanema River, Brazil. Journal of the World Aquaculture Society, v. 44, n. 6, p. 814-825, 2013. https://dx.doi.org/10.1111/jwas.12082

BARROSO, R. M.; MUÑOZ, A. E. P.; TAHIM, E. F.; WEBBER, D. C.; ALBUQUERQUE FILHO, A. C; PEDROSA FILHO, M. X. Diagnóstico da cadeia de valor da tilapicultura no Brasil. Brasília: Embrapa, 2018. 181 p.

BARTOZEK, E. C. R.; BUENO, N. C.; RODRIGUES, L. C. Influence of fish farming in net cages on phytoplankton structure: a case study in a subtropical Brazilian reservoir. Brazilian Journal of Biology, v. 70, n. 1, p. 145-155, 2014. http://dx.doi.org/10.1590/1519-6984.21912 
BORGES, P. A.; TRAIN, S.; DIAS, J. D.; BONECKER, C. C. Effects of fish farming on plankton structure in a Brazilian tropical reservoir. Hydrobiologia, v. 649, n. 1, p. 279291, 2010. https://dx.doi.org/10.1007/s10750-010-0271-2

BORGHETTI, J. R.; OSTRENSKY, A. Pesca e Aquicultura de Água Doce no Brasil. In: REBOUÇAS, A. C.; BRAGA, B.; TUNDISI, J. G. Águas Doces do Brasil. São Paulo: Escrituras, 1999.

BOYD, C. E. Water Quality in Ponds for Aquaculture. Alabama: Birmingham Publishing Company, 1990.

BRISTOW, C. E.; MORIN, A.; HESSLEIN, R. H.; PODEMSKI, C. L. Phosphorus budget and productivity of an experimental lake during the initial three years of cage aquaculture. Canadian Journal of Fisheries and Aquatic Sciences, v. 65, n.11, p. 2485-2495, 2008. https://dx.doi.org/10.1139/F08-155

BUENO, G. W.; MARENGONI, N. G.; GONÇALVES JÚNIOR, A. C.; BOSCOLO, W. R.; TEIXEIRA, R. A. Estado trófico e bioacumulação do fósforo total no cultivo de peixes em tanques-rede na área aquícola do reservatório de Itaipu. Acta Scientiarum Biological $\begin{array}{llllll}\text { Sciences, } & \text { v. } & 30, & \text { n.3, } & \text { p. } & \text { 237-243, }\end{array}$ https://dx.doi.org/10.4025/actascibiolsci.v30i3.519

BRASIL. Presidência da República. Decreto n 4.895, de 25 de novembro de 2003. Dispõe sobre a autorização de uso de espaços físicos de corpos d'água de domínio da União para fins de aquicultura, e dá outras providências. Diário Oficial [da] União: seção 1, Brasília, DF, n. 7, p. 62, 26 nov. 2003.

CETESB. Qualidade das águas interiores no estado de São Paulo. São Paulo: SMA, 2009.

CONAMA (Brasil). Resolução $\mathrm{n}^{\circ} 357$ de 17 de março de 2005. Dispõe sobre a classificação dos corpos de água e diretrizes ambientais para o seu enquadramento, bem como estabelece as condições e padrões de lançamento de efluentes, e dá outras providências. Diário Oficial [da] União: seção 1, Brasília, DF, n. 053, p. 58-63, 18 mar. 2005.

CROSSETTI, L. O.; BICUDO, C. E. M. Effects of nutrient impoverishment on phytoplankton biomass: a mesocosms experimental approach in a shallow eutrophic reservoir (Garças Pond), São Paulo, southeast Brazil. Revista Brasileira de Botânica, v. 28, n. 1, p. 95108, 2005. http://dx.doi.org/10.1590/S0100-84042005000100009

DAVID, G. S.; CARVALHO, E. D.; LEMOS, D. E. L.; SILVEIRA, A. N.; DALLǏAGLIOSOBRINHO, M. Ecological carrying capacity for intensivetilápia (Oreochromis niloticus) cage aquaculture in a large hydroelectric reservoir in Southeastern Brazil. $\begin{array}{llllllll}\text { Aquacultural Engineering, } & \text { v. } 66, \quad \text { n. } 1, & \text { p. } 30-40,\end{array}$ https://dx.doi.org/10.1016/j.aquaeng.2015.02.003

DEGEFU, F.; MENGISTU, S.; SCHAGERL, M. Influence of fish cage farming on water quality and plankton in fish ponds: a case study in the Rift Valley and North Shoa reservoirs, Ethiopia. Aquaculture, v. 316, n. 1-4, p. 129-135, 2011. https://dx.doi.org/10.1016/j.aquaculture.2011.03.010

DEMIR, N.; KIRKAGAC, M. U.; PULATSÜ, S.; BEKCAN, S. Influence of trout cage culture on water quality, plankton and benthos in an Anatolian DamLake. The Israeli Journal of Aquaculture - Bamidgeh, v. 53, n. 3-4, p. 115-127, 2001. 
FAO. The State of World Fisheries and Aquaculture. 2014. Available at: http://www.fao.org/3/a-i3720e.pdf. Access: 15 Nov. 2016.

FERNANDES, T. F.; ELEFTHERIOU, A.; ACKEFORS, H.; ELEFTHERIOU, M.; ERVIK, A.; SANCHEZ-MATA, A.; SCANLON, T.; WHITE, P.; COCHRANE, S.; PEARSON, T. H.; READ, P. A. The scientific principles underlying the monitoring of the environmental impacts of aquaculture. Journal of Applied Ichthyology, v. 17, n. 4, p. 181-193, 2001.

FU-GUANG, L.; SHUENN-DER, Y.; HON-CHENG C. Effect of temperature, stocking density and fish size on the ammonia excretion in palmetto bass (Morone saxatilis M. chrysops). Aquaculture Research, v. 40, n. 4, p. 450-455, 2009. https://dx.doi.org/10.1111/j.1365-2109.2008.02114.x

GUO, L.; LI, Z. Effects of nitrogen and phosphorus from fish cage-culture on the communities of a shallow lake in middle Yangtze River basin of China. Aquaculture, v. 226, n. 1, p. 201-212, 2003. https://dx.doi.org/10.1016/S0044-8486(03)00478-2

GUO, L.; ZHONGJIE, L.; XIE, P.; NI, L. Assessment effects of cage culture on nitrogen and phosphorus dynamics in relation to fallowing in a shallow lake in China. Aquaculture International, v. 17, n. 3, p. 229-241, 2009. https://dx.doi.org/10.1007/s10499-0089195-5

HONGYU, K.; SANDANIELO, V. L. M.; OLIVEIRA JUNIOR, G. J. Principal Component Analysis: theory, interpretations and applications. E\&S - Engineering and Science, v. 5, n. 1, p. 83-90, 2015.

IBGE. Produção da Pecuária Municipal 2015. Rio de Janeiro, 2016.

KAGGWA, M. N.; LITI, D. M.; SCHAGERL, M. Small tropical reservoirs and fish cage culture: a pilot study conducted in Machakos district, Kenya. Aquaculture International, v. 19, n. 5, p. 839-853, 2011. https://dx.10.1007/s10499-010-9403-y

KOREN, D. W.; GOULD, W. D.; BÉRDARD, P. Biological Removal of Ammonia and Nitrate from Simulated Mine and Mill Effluents. Hydrometallurgy, v. 56, n. 2, p. $127-144$, 2000. https://dx.doi.org/10.1016/S0304-386X(99)00088-2

KUBITZA, F. Tilápia: tecnologia e planejamento na produção comercial. Jundiaí: F. Kubitza, 2000.

MALLASEN, M.; BARROS, H. P.; YAMASHITA, E. Y. Produção de peixes em tanques-rede e a qualidade de água. Revista Tecnologia \& Inovação Agropecuária, v. 1, n. 1, p. 46$51,2008$.

MALLASEN, M.; CARMO, C. F.; TUCCI, A.; BARROS, H. P.; ROJAS, N. E. T.; FONSECA, F. S.; YAMASHITA, E. Y. Water quality in Cage system fish farm in Ilha Solteira reservoir, SP. Boletim do Instituto de Pesca, v. 38, n. 1, p. 15-30, 2012.

MCCUNE, B.; MEFFORD, M. J. PC-ORD. Multivariate Analysis of Ecological Data. Version 6.0. Gleneden Beach: MjM. Software design, 2011.

MERCANTE, C. T. J.; CABIANCA, M. A.; SILVA, D.; COSTA, S. V.; ESTEVES, K. E.; Water quality in free-fishing ponds located in the metropolitan region of Sao Paulo city, Brazil: an analysis of the eutrophication process. Acta Limnologica Brasiliensia, v. 16, n. 1, p. 95-102, 2004. 
MINELlO, M. C. S.; PAÇO, A. L.; CAETANO, L.; CASTRO, R. S. D.; FERREIRA, G.; PEREIRA, A. S.; PADILHA, P. M.; CASTRO, G. R. Avaliação sazonal de alguns parâmetros indicadores da qualidade de água no reservatório da usina hidrelétrica de Ilha Solteira-SP, Brasil. Global Science Technology, v. 3, n. 3, p. 98-104, 2010.

PIEDRAHITA, R. H. Reducing the potential environmental impact of tank aquaculture effluents through intensification and recirculation. Aquaculture, v. 226, n. 1-4, p. 35-44, 2003. https://doi.org/10.1016/S0044-8486(03)00465-4

ROJAS, N. E. T.; SANCHES, E. G. Considerações sobre a implantação e o manejo de sistemas aquaculturais esportivos. In: ESTEVES, K.E.; SANT'ANNA, C.L. Pesqueiros sob uma visão integrada de meio ambiente saúde pública e manejo. São Paulo: Rima, 2006. p. 177-200.

ROSINI. E. F.; TUCCI, A.; CARMO, C. F.; ROJAS, N. E. T.; BARROS, H. P.; MALLASEN, M. Changes in phytoplankton spatial and temporal dynamics in a Brazilian tropical oligotrophic reservoir after net cage installation. Brazilian Journal of Botany, v. 39, n. 2, p. 569-581, 2016. https://dx.doi.org/10.1007/s40415-016-0259-x

SOLORZANO, L. Determination of ammonia in natural waters by the phenolhypochlorite method. Limnology \& Oceanography, v. 14, n. 5, p. 799-801, 1969.

VALDERRAMA, G. C. The simultaneous analysis of total nitrogen and total phosphorus in natural waters. Marine Chemistry, v. 10, n. 2, p. 109-122, 1981. https://doi.org/10.1016/0304-4203(81)90027-X

VEENSTRA, J.; NOLEN, S.; CARROLL, J.; RUIZ, C. Impact of net pen aquaculture on lake water quality. Water Science and Technology, v. 47, n. 12, p. 293-300, 2003. https://doi.org/10.2166/wst.2003.0659

VILLARREAL, R. D. V.; TORRES, W. V. Body weight is inversely associated with ammonia excretion in red tilapia (Oreochromis Sp.). Revista Colombiana de Ciencias Pecuarias, v. 4, n. 2, p. 191-200, 2011. 


\begin{tabular}{|c} 
Ambiente \& Água - An Interdisciplinary Journal of Applied Science \\
ISSN 1980-993X - doi:10.4136/1980-993X \\
www.ambi-agua.net \\
E-mail: ambi.agua@gmail.com
\end{tabular}

\title{
Evaluation of the use of fertilizer obtained from pharmaceutical effluent
}

\author{
ARTICLES doi:10.4136/ambi-agua.2262
}

Received: 28 Mar. 2018; Accepted: 26 May 2019

\author{
Carina Aline Prado ${ }^{1}$; Mariana Paiva Batagini Giron ${ }^{1}$; \\ Fernanda Gonçalves Mendes $^{2}{ }^{(D}$; Marco Aurélio Kondracki de Alcântara ${ }^{2 *}$;D; \\ Hélcio José Izário Filho1 ${ }^{1}$ \\ ${ }^{\mathbf{1}}$ Escola de Engenharia de Lorena (EEL-USP), Lorena, SP, Brasil \\ Departamento de Engenharia de Química (DEQUI).E-mail: carinaprado@usp.br, \\ marianabatagini@usp.br, helcio@dequi.eel.usp.br \\ ${ }^{2}$ Escola de Engenharia de Lorena (EEL-USP), Lorena, SP, Brasil \\ Departamento de Ciências Básicas e Ambientais (LOB). \\ E-mail: fernanda@alunos.eel.usp.br,marko@usp.br \\ *Corresponding author
}

\begin{abstract}
Sustainability encompasses several aspects, one of which is the reuse of nutrient-rich effluent. In recent years, improper disposal of pharmaceuticals and pharmaceutical effluent, which contain recalcitrant compounds, has caused great environmental damage. An alternative disposal strategy that has been studied for several residues is their reuse for agricultural purposes. This work evaluated the potential of using pharmaceutical effluent for fertilizing Schinus molle, a native Brazilian species locally known as "aroeira-salsa." Effluent was pretreated by chemical precipitation, and the solid phase was tested as fertilizer. Seedlings were grown in soil or compost. The soil used was classified as Red-Yellow Acrisol with medium loamy texture and high Al content, which is typically found in the Vale do Paraíba region, São Paulo, Brazil. Two agricultural composts were used as substrate, both from the Taboão Ecological Park located in Vale do Paraíba. Fertilizer application improved the physicochemical characteristics of all growing media, increasing $\mathrm{C}, \mathrm{N}, \mathrm{P}, \mathrm{K}, \mathrm{Mg}$, and $\mathrm{Ca}$ contents, base saturation, and $\mathrm{pH}$, while decreasing $\mathrm{Al}$ content and density. Fertilization improved nutrient absorption and plant growth.
\end{abstract}

Keywords: fertilizer, pharmaceutical effluent, sustainability.

\section{Avaliação do uso de fertilizante obtido a partir de efluente de indústria farmacêutica}

\section{RESUMO}

A sustentabilidade envolve um número grande de aspectos. Entre eles, o de aproveitamento de nutrientes presentes em efluentes tratados com diferentes tipos de processos. Nos últimos anos, têm sido detectados danos ambientais decorrentes do despejo de fármacos e de efluentes da indústria farmacêutica, em função da difícil recalcitrância de alguns componentes das formulações. Um destino que tem sido estudado para diversos tipos de rejeitos é a aplicação no solo com finalidade agrícola. Visando o aproveitamento de efluentes da indústria farmacêutica 
(e consequente redução de um passivo ambiental), foi desenvolvido e utilizado um fertilizante obtido a partir da precipitação química (pré-tratamento) de um efluente. O fertilizante obtido foi testado para espécie Schinus molle, popularmente denominada de aroeira-salsa no Brasil. As plantas se desenvolveram tendo como substrato solo ou compostos orgânicos. O solo utilizado foi um Argissolo Vermelho-Amarelo textura média, característico da região do vale do Paraíba, Estado de São Paulo, Brasil, com alto teor de alumínio. Foram utilizados dois compostos orgânicos, originados de resíduos agrícolas, ambos provenientes do Parque Ecológico do Taboão, localizado no Vale do Paraíba. A aplicação do fertilizante em todos os substratos melhorou as suas características em relação aos teores de $\mathrm{C}, \mathrm{N}, \mathrm{P}, \mathrm{K}, \mathrm{Mg}, \mathrm{Ca}$, saturação por bases, $\mathrm{pH}, \mathrm{Al}$ e densidade. Também a absorção de nutrientes e o crescimento das plantas foi beneficiado com a aplicação do fertilizante.

Palavras-chave: efluente de indústria farmacêutica, fertilizante, sustentabilidade.

\section{INTRODUCTION}

Environmental sustainability involves multiple aspects. One is the reuse of waste materials rich in nutrients and organic matter. Adequate disposal of nutrient-rich effluent prevents chemical and microbiological contamination and reduces environmental impact. Incorporation of wastewater into the soil or other agricultural substrates for fertilization purposes is an interesting alternative from a sustainability and environmental conservation perspective. Wastewater treatment can produce profitable materials, thereby favoring sustainable economic activities and fostering the creation of economically viable environmental programs and new waste disposal sites for industries. Such projects reduce environmental pollution and impacts and raise public awareness of environmental issues (Gouveia, 2012).

Effluents must meet several requirements prior to discharge into water bodies, according to CETESB Article 18 (CETESB, 2002) and CONAMA Resolution No. 430 (CONAMA, 2005). Thus, adequate treatment of wastewaters is of extreme importance for environmental preservation and law compliance. In some cases, depending on the recalcitrance of its components, wastewater may require a post-treatment step to meet discharge standards, such as biological treatment.

Pharmaceutical industries generate large amounts of waste with high organic content. Residues resulting from the production of antibiotics are an example of materials that contain recalcitrant components of high molecular weight. At high concentrations, these compounds are difficult to treat by conventional methods. For this reason, pharmaceutical wastewater is frequently dried and incinerated rather than treated, especially when the cost/benefit ratio is high. It thus becomes necessary to resort to emerging technologies or to a combination of two or more processes (for instance, chemical precipitation and advanced oxidation process) to treat pharmaceutical wastewater.

Discharge of pharmaceuticals and untreated pharmaceutical wastewater into domestic sewer lines, surface water, and groundwater has caused great environmental damage (Melo et $a l ., 2009)$. These wastes contain compounds of several therapeutic classes, such as hormones, analgesics, and antibiotics.

The agricultural industry generates large amounts of solid waste, including straw, crop residues, and animal wastes. Hundreds of metric tons of organic waste are generated annually in Brazil, which can be either a serious source of pollution if untreated or a valuable agricultural input to replace industrialized fertilizers.

Composting, one of the most environmentally friendly alternatives for recycling organic waste, is a controlled process of organic waste degradation under aerobic conditions. Compost can supply essential nutrients, especially carbon, for plant growth and also improve some physical characteristics of the soil, including soil density, a property that varies according to 
soil compaction. The decrease in soil density promoted by the addition of organic matter facilitates root penetration and increases total porosity, macroporosity, water permeability, and water infiltration (FAO, 2005).

An environmentally sustainable agricultural system requires that soil nutrient and organic matter reserves be preserved. Carbon and nitrogen are important for plant growth. Stable soil organic matter is a source of essential nutrients for plant development (LAL, 2008; Misiewicz et al., 2017).

Achieving sustainability is the goal of various agricultural production systems (Karlen and Rice, 2017). Agroforestry, for instance, has seedling cultivation and tree planting as some of its core practices. Different substrates are used to grow seedlings until they can be planted. Substrate is a medium for growing plants $e x$ situ. Mineral soil was the first substrate used for ex situ cultivation. Currently, most substrates consist of a combination of two or more components, which can be chosen from a large variety of materials.

Many studies showed that soil amendment with organic waste positively influences soil characteristics and plant development. Gomes et al. (2004) conducted a study on the cultivation of Anadenanthera colubrina in Red-Yellow Acrisol and reported that nutrient addition promoted an increase in base saturation, which in turn improved plant growth and resulted in increased dry weight. Cultivated species require the addition of adequate levels of nutrients to the culture medium. Soil organic matter is the primary source of nutrients in cultivated soils and serves as a temporary nutrient reserve. Its importance in maintaining and improving physical characteristics of the soil, such as water and air infiltration, water retention, and soil aggregation, and in controlling the fate of pesticides is well known (Srinivasan et al., 2012).

Maintaining and increasing soil organic matter levels in the highly weathered soils of tropical regions is a great challenge. In tropical agricultural areas, organic residues and fertilizers are frequently applied to the soil to enhance microbial activity and mineralization rates (Guimarães et al., 2014).

Studies analyzed the effects of wastewater or effluent irrigation. Depending on the characteristics of the material, either positive or negative effects may follow. A comprehensive review of this topic was published by Kaur and Sharma (2013). The study provided a list of effluents that can be used for fertilization purposes but underscored that some may negatively impact physical and chemical soil characteristics. Kalyva (2017) presented a review of the disposal of pharmaceuticals in the environment, discussing their fate, transport, aquatic and terrestrial pollution potential, and risks to populations. Probably because of the well-known negative impacts of pharmaceuticals on the environment, few works focus on investigating the beneficial effect of pharmaceutical wastewater irrigation.

This study aimed to evaluate the potential of using a fertilizer obtained from pharmaceutical wastewater to grow Schinus molle in different substrates. The effects of fertilizer addition on chemical and physical characteristics of substrates, plant growth, and nutrient absorption were evaluated.

\section{MATERIALS AND METHODS}

Pharmaceutical effluent, specifically, effluent from syrup production, was used to obtain the fertilizer. In addition to pharmaceuticals, the effluent had a high content of sucrose, N, K, $\mathrm{Mg}, \mathrm{Na}$, and $\mathrm{P}$ (in the form of phosphate). The presence of these elements and the high $\mathrm{C}$ content (present in sucrose) makes this material a potential source of plant nutrients.

As the effluent had a high organic load, treatment by oxidation processes would not be feasible. Organic matter was therefore chemically precipitated via an innovative process. Sucrose was the major component of the precipitate. Detailed information about the precipitation reaction will not be presented in this paper because the process is being patented. After precipitation, pretreated wastewater was submitted to vacuum filtration to separate the 
solid phase from the liquid phase. A calcium hydroxide $\left(\mathrm{Ca}(\mathrm{OH})_{2}\right)$ solution was added to the solid phase at $1: 3(\mathrm{w} / \mathrm{w})$. The mixture was oven-dried at $105^{\circ} \mathrm{C}$ to avoid chemical and microbiological degradation during storage. The dried material was ground and sieved through $2 \mathrm{~mm}$ sieves, affording the fertilizer used in plant experiments. Grinding and sieving provides powders with standardized particle sizes and promotes particle homogenization, which improves soil reactivity. The liquid phase obtained after filtration was not used in this work. It will be treated by an oxidation process to meet the legal requirements for wastewater discharge. Figure 1 shows a flow diagram of the process used to obtain the fertilizer. The process can be used in an industrial setting.

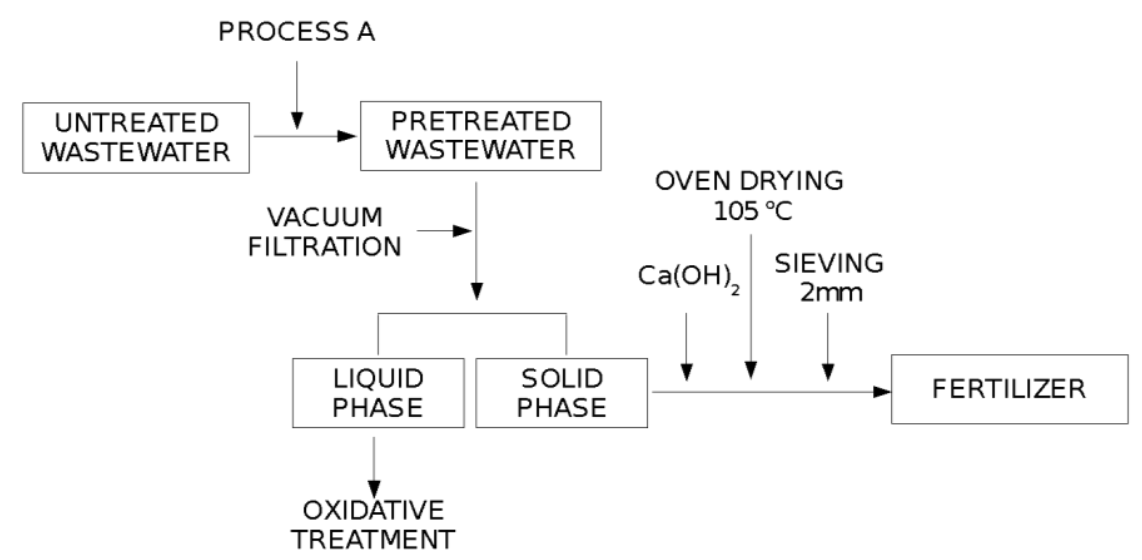

Figure 1. Scheme for obtaining fertilizer from untreated pharmaceutical effluent. Process A is used in an innovative process (patent pending).

S. molle (popularly known in Brazil as "aroeira-salsa") was used for the experiments. Samples were collected from the Taboão Ecological Park, Lorena, São Paulo, Brazil $\left(22^{\circ} 47^{\prime} 26^{\prime \prime} \mathrm{S} 45^{\circ} 66^{\prime} 11^{\prime \prime} \mathrm{W}\right)$. The species grows rapidly and has a high ornamental value in the Zona da Mata mesoregion of Minas Gerais (Mafia et al., 2004). It is naturally found in semideciduous seasonal forests in Paraná and in other ecosystems. The species is also available in nurseries throughout Vale do Paraíba.

We evaluated the effects of two factors, substrate and fertilization, on plant growth and nutrition. Three types of substrates were evaluated with and without the addition of fertilizer, in triplicate, totaling 18 experiments.

Soil or composts (obtained by aerobic composting) were used as substrates. Red-Yellow Acrisol with medium loamy texture (EMBRAPA, 2006) was collected at a depth of 0-20 cm. The soil is typically found in the study region. Composts were produced in the Taboão Ecological Park, located in Vale do Paraíba. Compost 1 was obtained from a nursery that grows seedlings of trees native to the Atlantic Forest. It was composed of several organic residues generated in the Park, such as pruning and mowing residues, cattle manure, and wastewater from washing tubes and livestock pens, as well as sand and worm humus. Compost 2 was composed of grasses and leaves and was obtained from a nursery in the Taboão Ecological Park. Fertilizer was used at $40 \mathrm{~g} \mathrm{~kg}^{-1}$ soil to provide the necessary amount of nitrogen for nursery growth (Van Raij et al., 1997).

Substrates and fertilizer were sieved through a $2 \mathrm{~mm}$ sieve. One-month-old seedlings were planted in $0.25 \mathrm{~L}$ black plastic bags and kept at room temperature for 90 days. Plants received the same amount of water throughout the growing period. All nursery practices (establishment of the nursery site, seedling formation, and seedling handling) were in accordance with the guidelines of the Brazilian Agricultural Research Corporation (EMBRAPA, 2016).

After the growing period, substrates and aerial parts of the plants were characterized 
chemically and physically following the methods of EMBRAPA (2009; 2011). Aerial parts were oven dried at $65^{\circ} \mathrm{C}$ and the dry weight was measured. Plant height was also determined. The density of growing media was determined or quantified following the methods of EMBRAPA (2009).

Available $\mathrm{Ca}, \mathrm{Mg}, \mathrm{K}, \mathrm{Na}$, and $\mathrm{P}$ were extracted with Mehlich 3 extraction, and exchangeable $\mathrm{Al}$ was extracted using a $1 \mathrm{~mol} \mathrm{~L}^{-1} \mathrm{KCl}$ solution. The elements were quantified by inductively coupled plasma optical emission spectrometry (ICP-OES). Chemical oxygen demand (COD) was determined to estimate the amount of C. Organic matter was oxidized by potassium dichromate in acidic medium at high temperature in the presence of a catalyst. Subsequently, absorbance was measured at $620 \mathrm{~nm}$. N content was determined by digesting the sample in acidic medium, followed by distillation using borate/sodium hydroxide buffer to adjust the $\mathrm{pH}$ to 9.5 . The concentration of ammonia $\mathrm{N}$ was quantified spectrophotometrically at $420 \mathrm{~nm}$. Analyses were performed when the plants were collected and at the end of the evaluation period (90 days).

\section{RESULTS AND DISCUSSION}

Table 1 shows the physicochemical characteristics of the fertilizer. Its neutral $\mathrm{pH}$ (7.0), high content of organic carbon and base cations $(\mathrm{Ca}, \mathrm{Mg}$, and $\mathrm{K})$, and undetectable $\mathrm{Al}$ content are interesting features for agricultural application.

Table 1. Physicochemical characteristics of the fertilizer.

\begin{tabular}{lcc}
\hline Parameter & Unit & Value \\
\hline $\mathrm{pH}$ & - & $7.0 \pm 0.0$ \\
$\mathrm{Al}$ & $\mathrm{mg} \mathrm{g}^{-1}$ & $<0.001$ \\
$\mathrm{Ca}$ & $\mathrm{mg} \mathrm{g}^{-1}$ & $405.85 \pm 0.01$ \\
$\mathrm{Mg}$ & $\mathrm{mg} \mathrm{g}^{-1}$ & $36.21 \pm 0.01$ \\
$\mathrm{P}$ & $\mathrm{mg} \mathrm{g}^{-1}$ & $35.96 \pm 0.07$ \\
$\mathrm{~K}$ & $\mathrm{mg} \mathrm{g}^{-1}$ & $111.23 \pm 0.01$ \\
$\mathrm{Na}$ & $\mathrm{mg} \mathrm{g}^{-1}$ & $16.10 \pm 0.01$ \\
$\mathrm{~N}$ & $\mathrm{mg} \mathrm{g}^{-1}$ & $52.35 \pm 0.11$ \\
$\mathrm{OC}$ & $\mathrm{mg} \mathrm{dm}^{-3}$ & $3100 \pm 0.01$ \\
Density & $\mathrm{kg} \mathrm{dm}^{-3}$ & $1.017 \pm 0.010$ \\
\hline OC, organic carbon. Values represent the \\
mean \pm standard deviation. Three replicates.
\end{tabular}
Table 2.

The physicochemical characterization of fertilized and unfertilized substrates is shown in

Several beneficial effects of the addition of fertilizer to growing media were observed, such as an increase in $\mathrm{pH}$, cation content, and base saturation and a decrease in exchangeable Al. A three-fold increase in organic carbon content was obtained with the addition of fertilizer as well as an increase in plant-available $\mathrm{P}$ and N. Regarding the substrates' physical characteristics, there was a small decrease in soil density, which is also a favorable effect. An increase in $\mathrm{Na}$ content was observed in fertilized soil as compared with unfertilized soil; however, the same was not observed for composts 1 and 2. This effect in soil nutrient content may be due to the chemical components used in the process to obtain the fertilizer. 
Table 2. Physicochemical characteristics of fertilized and unfertilized substrates.

\begin{tabular}{|c|c|c|c|c|c|c|c|}
\hline \multirow{2}{*}{ Parameter } & \multirow{2}{*}{ Unit } & \multirow{2}{*}{$\frac{\text { Soil }}{\text { Unfertilized }}$} & \multirow{2}{*}{$\begin{array}{l}\text { Compost } 1 \\
\text { Fertilized }\end{array}$} & \multicolumn{4}{|c|}{ Compost 2} \\
\hline & & & & Unfertilized & Fertilized & Unfertilized & Fertilized \\
\hline $\mathrm{pH}$ & - & $5.7 \pm 0.1$ & $7.0 \pm 0.0$ & $5.6 \pm 0.0$ & $6.7 \pm 0.0$ & $5.4 \pm 0.0$ & $6.5 \pm 0.0$ \\
\hline $\mathrm{Al}$ & $\mathrm{mg} \mathrm{g}^{-1}$ & $48.00 \pm 0.00$ & $46.50 \pm 0.01$ & $37.41 \pm 0.02$ & $35.21 \pm 0.05$ & $38.41 \pm 0.01$ & $31.74 \pm 0.05$ \\
\hline $\mathrm{Ca}$ & $\mathrm{mg} \mathrm{g}^{-1}$ & $1.04 \pm 0.00$ & $84.12 \pm 0.01$ & $4.02 \pm 0.01$ & $66.12 \pm 0.02$ & $10.12 \pm 0.01$ & $424.2 \pm 0.0$ \\
\hline $\mathrm{Mg}$ & $\mathrm{mg} \mathrm{g}^{-1}$ & $<0.001$ & $36.20 \pm 0.00$ & $0.01 \pm 0.02$ & $3.65 \pm 0.01$ & $0.08 \pm 0.00$ & $40.1 \pm 0.1$ \\
\hline $\mathrm{P}$ & $\mathrm{mg} \mathrm{g}^{-1}$ & $23.20 \pm 0.01$ & $28.73 \pm 0.01$ & $6.08 \pm 0.04$ & $29.73 \pm 0.01$ & $6.19 \pm 0.01$ & $36.9 \pm 0.1$ \\
\hline K & $\mathrm{mg} \mathrm{g}^{-1}$ & $87.80 \pm 0.01$ & $96.05 \pm 0.01$ & $7.20 \pm 0.00$ & $97.20 \pm 0.03$ & $9.70 \pm 0.02$ & $88.01 \pm 0.08$ \\
\hline $\mathrm{V} \%$ & - & $25 \pm 0$ & $45 \pm 0$ & $22 \pm 0$ & $56 \pm 0$ & $20 \pm 0.0$ & $50 \pm 0$ \\
\hline $\mathrm{Na}$ & $\mathrm{mg} \mathrm{g}^{-1}$ & $<0.001$ & $0.013 \pm 0.004$ & $<0.001$ & $<0.001$ & $<0.001$ & $1.301 \pm 0.003$ \\
\hline $\mathrm{N}$ & $\mathrm{mg} \mathrm{g}^{-1}$ & $26.7 \pm 0.0$ & $61.4 \pm 0.0$ & $0.2 \pm 0.0$ & $31.4 \pm 0.0$ & $12 \pm 0.0$ & $61.4 \pm 0.0$ \\
\hline $\mathrm{OC}$ & $m g \mathrm{mg}^{-3}$ & $36.20 \pm 0.00$ & $106.40 \pm 0.01$ & $45.20 \pm 0.01$ & $106.4 \pm 0.0$ & $32.00 \pm 0.01$ & $105.4 \pm 0.0$ \\
\hline $\mathrm{D}_{\mathrm{s}}$ & $\mathrm{kg} \mathrm{dm}^{-3}$ & $1.217 \pm 0.020$ & $1.204 \pm 0.060$ & $1.227 \pm 0.001$ & $1.204 \pm 0.010$ & $1.257 \pm 0.002$ & $1.214 \pm 0.003$ \\
\hline
\end{tabular}

There is a lack of research on the use of pharmaceutical wastewater as soil fertilizer, which hinders comparison of the results obtained in the present work. However, various studies have assessed the impacts of different wastewaters on soil. In a long-term field experiment, Al Omron et al. (2012) observed an increase in soil organic matter (from 17\% to 30\%) in sewage-irrigated soils as compared with soils irrigated with well water. The increase of 13 percentage points is considerably lower than that observed in the present study. Sewage irrigation reduced soil bulk density, as observed in the present study with the addition of wastewater-derived fertilizer.

Positive and negative reported effects of wastewater on soil $\mathrm{pH}$ have been reported in the literature. Al Omron et al. (2012) observed that soil $\mathrm{pH}$ decreased with sewage irrigation. Contrarily, other authors (El-Hady, 2007; Osaigbovo and Orhue, 2006; Rusan et al., 2007) reported an increase in soil $\mathrm{pH}$ with wastewater irrigation, as was the case in the present study. 
Domestic sewage sludge might increase soil fertility. Yadav et al. (2002) reported a build up of total $\mathrm{N}\left(2908 \mathrm{~kg} \mathrm{ha}^{-1}\right)$, available $\mathrm{P}\left(58 \mathrm{~kg} \mathrm{ha}^{-1}\right)$, and available $\mathrm{K}\left(305 \mathrm{~kg} \mathrm{ha}^{-1}\right)$ in the soil. In the present study, soil $\mathrm{N}$ increased from 31.2 to $49.4 \mathrm{mg} \mathrm{kg}^{-1}$ after fertilization. Considering that the lowest soil bulk density was $2.4 \mathrm{~kg} \mathrm{dm}^{-3}$, we estimate that the increase in $\mathrm{N}$ content obtained in our study (from 75 to $118 \mathrm{~kg} \mathrm{ha}^{-1}$, approximately) was substantially higher than that of Yadav et al. (2002). P content increased from 13 to $73 \mathrm{~kg} \mathrm{ha}^{-1}$, reaching values higher than that of the mentioned study, whereas $\mathrm{K}$ content increased from 9 to $216 \mathrm{~kg} \mathrm{ha}^{-1}$ because the fertilizer was relatively poor in this nutrient.

We emphasize that this type of comparison should be performed with extreme caution. The wastewaters evaluated in the above-mentioned studies are different from the wastewater used in of our study, as are the rates and periods of application, soil type, and plants. The comparisons indicate that the changes in soil parameters observed in this work are of the same order of magnitude as those reported in the literature.

Sodification ( $\mathrm{Na}$ accumulation) might occur with as a result of frequent wastewater irrigation (FAO, 2007). In this case, Na might displace other cations, such as $\mathrm{Ca}$ and $\mathrm{Mg}$. High sodium levels might affect soil structure by reducing soil permeability (Sumner, 1993). In the present study, soil $\mathrm{Na}$ content did not increase substantially with fertilizer application. However, seedlings were cultivated for a short period. Long-term field application is necessary to evaluate better the effects of $\mathrm{Na}$ on soil and plant characteristics.

Figure 2 shows photographs of plants at 30,60, and 90 days of cultivation in fertilized and unfertilized Acrisol. Photographs of plants grown in compost 1 and 2, fertilized and unfertilized, are shown in Figure 3. Fertilized plants had a higher growth rate than unfertilized plants; the highest growth rate was that of plants grown in compost 1 .

A

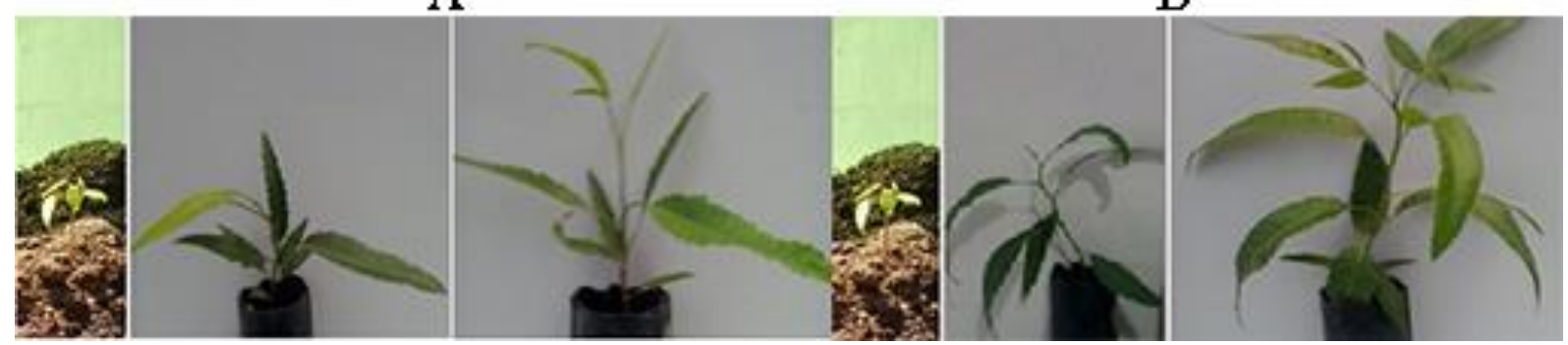

Figure 2. Development of plants grown in Acrisol at 30, 60, and 90 days of cultivation (from left to right). (A). Unfertilized soil and (B). fertilized soil.

A
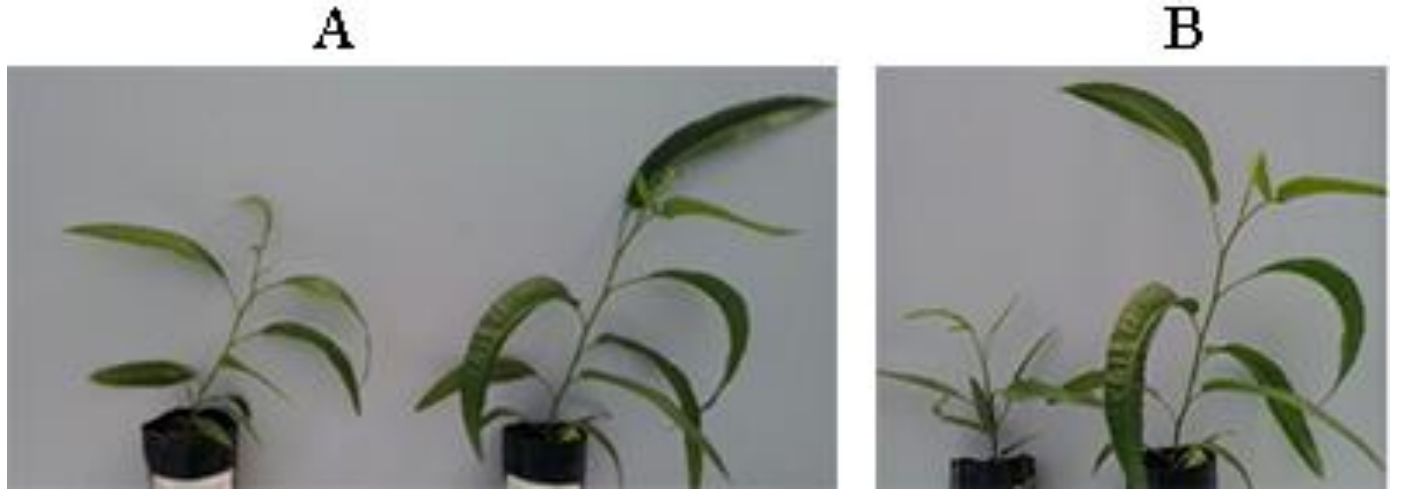

Figure 3. Development of plants grown in fertilized (right) and unfertilized (left) composts at 90 days of cultivation. (A) Plants grown in compost 1 and (B) plants grown in compost 2.

Table 3 shows the characteristics of plants cultivated in fertilized and unfertilized growing media. 
Table 3. Characteristics of aerial parts of plants grown for 90 days in fertilized and unfertilized substrates.

\begin{tabular}{|c|c|c|c|c|c|c|c|}
\hline \multirow{2}{*}{ Parameter } & \multirow{2}{*}{ Unit } & \multicolumn{2}{|c|}{ Soil } & \multicolumn{2}{|c|}{ Compost 1} & \multicolumn{2}{|c|}{ Compost 2} \\
\hline & & Unfertilized & Fertilized & Unfertilized & Fertilized & Unfertilized & Fertilized \\
\hline $\mathrm{Al}$ & $\mathrm{mg} \mathrm{g}^{-1}$ & $0.018 \pm 0.006$ & $0.030 \pm 0.011$ & $0.004 \pm 0.001$ & $<0.001$ & $0.300 \pm 0.021$ & $0.033 \pm 0.009$ \\
\hline $\mathrm{Ca}$ & $\mathrm{mg} \mathrm{g}^{-1}$ & $0.08 \pm 0.01$ & $160.5 \pm 0.0$ & $8.50 \pm 0.01$ & $85.5 \pm 0.0$ & $0.10 \pm 0.03$ & $81.0 \pm 0.1$ \\
\hline $\mathrm{Mg}$ & $\mathrm{mg} \mathrm{g}^{-1}$ & $0.36 \pm 0.02$ & $5.30 \pm 0.01$ & $0.79 \pm 0.01$ & $5.42 \pm 0.02$ & $0.50 \pm 0.05$ & $8.10 \pm 0.02$ \\
\hline $\mathrm{P}$ & $\mathrm{mg} \mathrm{g}^{-1}$ & $0.89 \pm 0.01$ & $31.1 \pm 0.0$ & $0.51 \pm 0.02$ & $102.3 \pm 0.0$ & $0.92 \pm 0.01$ & $89.0 \pm 0.0$ \\
\hline $\mathrm{K}$ & $\mathrm{mg} \mathrm{g}^{-1}$ & $17.02 \pm 0.01$ & $36.60 \pm 0.03$ & $30.21 \pm 0.03$ & $39.21 \pm 0.02$ & $17.30 \pm 0.01$ & $37.0 \pm 0.0$ \\
\hline $\mathrm{Na}$ & $\mathrm{mg} \mathrm{dm} \mathrm{m}^{-3}$ & $<0.001$ & $3.00 \pm 0.02$ & $0.550 \pm 0.012$ & $7.60 \pm 0.01$ & $0.110 \pm 0.009$ & $7.10 \pm 0.02$ \\
\hline $\mathrm{N}$ & $\mathrm{mg} \mathrm{g}^{-1}$ & $12.0 \pm 0.0$ & $55.4 \pm 0.0$ & $20.1 \pm 0.1$ & $56.0 \pm 0.0$ & $11.3 \pm 0.0$ & $50.0 \pm 0.0$ \\
\hline $\mathrm{OC}$ & $\mathrm{mg} \mathrm{dm} \mathrm{m}^{-3}$ & $201.2 \pm 0.0$ & $638.4 \pm 0.0$ & $202.4 \pm 0.0$ & $640.3 \pm 0.0$ & $203.0 \pm 0.0$ & $210.0 \pm 0.0$ \\
\hline Height & $\mathrm{mm}$ & $97.1 \pm 0.0$ & $151.6 \pm 0.0$ & $80.2 \pm 0.0$ & $160.2 \pm 0.0$ & $80.1 \pm 0.0$ & $120.0 \pm 0.0$ \\
\hline Dry weight & $\mathrm{g}$ & $4.2 \pm 0.00$ & $6.2 \pm 0.0$ & $6.0 \pm 0.0$ & $10.0 \pm 0.0$ & $5.0 \pm 0.0$ & $7.0 \pm 0.0$ \\
\hline
\end{tabular}

OC, organic carbon. Values represent the mean \pm standard deviation. Three replicates.

Fertilized plants were taller and had a greater absorption of $\mathrm{C}, \mathrm{N}$, and $\mathrm{P}$ than unfertilized plants. Plants grown in compost 1 had a lower Ca content than plants grown in compost 2, probably because compost 1 had more nutrients.

The literature presents evidence of the environmental contamination potential of pharmaceuticals. Carter et al. (2014) studied the fate (in-soil degradation, transport, and plant uptake) of analytical grade carbamazepine, diclofenac, propranolol, and sulfamethazine in Tepko soil in Australia. Wu et al. (2015) studied the fate of pharmaceuticals and personal care products added to soil irrigated with treated wastewater or biosolid-amended soil. Carter et al. (2018) studied the sorption, plant uptake, and metabolism of benzodiazepines, a widely used class of pharmaceuticals that are recalcitrant to wastewater treatment. According to the authors, the mechanisms involved in pharmaceutical uptake and transport in plants are very complex. 
Few studies focus on the effects of wastewater on plant nutrient uptake. Cruz et al. (2016) reported that Tabebuia spp. grew at a faster rate in Acrisol fertilized with C, N, P, and Ca than in unfertilized soil. However, because of the complexity of plant uptake and transport mechanisms, it is very difficult to compare the effects of different wastewaters on plant nutrient absorption.

\section{CONCLUSION}

Effluent-derived fertilizer improved the characteristics of all growing media, increasing $\mathrm{pH}$ and $\mathrm{C}, \mathrm{N}, \mathrm{P}, \mathrm{K}, \mathrm{Mg}$, and Ca contents while decreasing $\mathrm{Al}$ content and soil density. However, fertilization increased $\mathrm{Na}$ content. Further research is needed to assess the effects of fertilization on soil Na levels.

Plant growth (measured by dry weight and height) and nutrient uptake were enhanced by fertilization. The best results were obtained using compost 1 , as it contained the highest concentration of nutrients.

\section{REFERENCES}

Al OMRON, A. M.; EL-MAGHRABY, S. E.; NADEEM, M. E. A.; EL-ETER, A. M.; ALMOHANI, H. Long term effect of irrigation with the treated sewage effluent on some soil properties of Al-Hassa Governorate, Saudi Arabia. Journal of the Saudi Society of Agricultural Sciences, v. 11, p. 15-18, 2012. https://doi.org/10.1016/j.jssas.2011.04.004

CARTER, L. J.; HARRIS, H.; WILLIAMS, M.; RYAN, J. J.; KOOKANA, R. S.; BOXALL, A. B. A. Fate and uptake of pharmaceuticals in soil-plant systems. Journal of Agricultural and Food Chemistry, v. 62, p. 816-825, 2014. https://doi.org/10.1021/jf404282y

CARTER, L. J.; WILLIAMS, M.; MARTIN, S.; KAMALUDEEN, S. P. B.; KOOKANA, R. S. Sorption, plant uptake and metabolism of benzodiazepines. Science of the Total $\begin{array}{llllll}\text { Environment, } & \text { v. } & 628-629, & \text { p. } & 18-25, & \end{array}$ https://doi.org/10.1016/j.scitotenv.2018.01.337

CETESB. Proposta de Índices e Qualidade de Água para o Estado de São Paulo. Coletânea de textos da Cetesb. São Paulo: CETESB, 2002.

CONAMA (Brasil). Resolução ${ }^{\circ} 357$ de 17 de março de 2005. Dispõe sobre a classificação dos corpos de água e diretrizes ambientais para o seu enquadramento, bem como estabelece as condições e padrões de lançamento de efluentes, e dá outras providências. Diário Oficial [da] União: seção 1, Brasília, DF, n. 053, p. 58-63, 18 mar. 2005.

CRUZ, A. I. G.; AMBROZIO, A. M. H.; PUGA, F. P.; SOUZA, F. L.; NASCIMENTO, M. M. Economia brasileira: conquista dos últimos dez anos e perspectivas para o futuro. Brasília: Ministério do Desenvolvimento, Indústria e Comércio Exterior, 2016. 30p.

El-HADY, B. A. A. Compare the effect of polluted and river Nile irrigation water on contents of heavy-metals of some soils and plants. Research Journal of Agriculture and Biological Sciences, v. 3, n. 4, p. 287-294, 2007.

EMBRAPA. Sistema Brasileiro de Classificação de Solos. Brasília, 2006. 306p.

EMBRAPA. Manual de Métodos de Análises Químicas para Avaliação da Fertilidade do Solo. Brasília, 2009. 627p. 
EMBRAPA. Manual de Métodos de Análises de Solo. Brasília, 2011. 225 p.

EMBRAPA. Manual de viveiro e produção de mudas: espécies arbóreas nativas do Cerrado. Brasília, 2016. 124p.

FAO. The Importance of Soil Organic Matter: key to drought-resistant soil and sustained food production. Rome, 2005. 95p.

FAO. Advances in the Assessment and Monitoring of Salinization and Status of Biosaline Agriculture. Reports of Expert Consultation Held in Dubai, United Arab Emirates. Rome, 2007.

GUIMARÃES, D. V.; GONZAGA, M. I. S.; MELO NETO, J. O. Management of soil organic matter and carbon storage in tropical fruit crops. Revista Brasileira de Engenharia Agrícola e Ambiental, v. 18, n. 3, p. 301-306, 2014. https://dx.doi.org/10.1590/S141543662014000300009

GOMES, K. C. O.; PAIVA, H. N.; NEVES, J. C. L.; BARRIS, N. F.; SILVA, S. R. Influência da saturação por bases e do fosfato no crescimento de mudas de Angico-Branco. Revista Árvore, v. 28, n. 5, p. 785-792, 2004.

GOUVEIA, N. Resíduos sólidos urbanos: Impactos socioambientais e perspectiva de manejo sustentável com inclusão social. Ciência e Saúde coletiva, v. 17, n. 6, p. 1503-1510, 2012.

KALYVA, M. Fate of pharmaceuticals in the environment: A review. Sweden: Umeå University, Dept. of Ecology and Environmental Science, 2017. 30 p.

KAUR, V.; SHARMA, G. Effects of industrial effluent on soil characteristics: A review. International Journal of Advances in Engineering Science and Technology, v. 3, n. 3, p. 201-207, 2013.

KARLEN, D. L.; RICE, C. W. Enhancing Soil Health to Mitigate Soil Degradation. Switzerland: MDPI, 2017. 338p.

LAL, R. Soils and sustainable agriculture: A review. Agronomy for Sustainable Development, v. 28, n. 1, p. 57-64, 2008. https://doi.org/10.1051/agro:2007025

MAFIA, R. G.; ALFENAS, A. C.; ANDRADE, G. G. G.; NEVES, D. A.; GRAÇA, R. N.; ALONSO, S. K. Incidência de Meliola rhoina como fator limitante à produção de mudas de Schinus molle para fins de arborização. Fitopatologia Brasileira, v. 29, n. 2, p. 224 , 2004.

MELO, S. A. S.; TROVO, A. G.; BAUTITZ, I. R.; NOUGUEIRA, R. F. P. Degradação de fármacos residuais por processos oxidativos avançados. Química Nova, v. 32, n. 1, p. 188-197, 2009.

MISIEWICZ, T.; SHADE, J.; CROWDER, D.; DELATE, K.; SCILIGO, A.; SILVA, E. Increasing Agricultural Sustainability Through Organic Farming: Outcomes from the 2016 Organic Confluences Summit. Washington: The Organic Center, 2017. 32 p.

OSAIGBOVO, A. U.; ORHUE, E. R. Influence of pharmaceutical effluent on some soil chemical properties and early growth of maize (Zea mays L.). African Journal of Biotechnology, v. 5, n. 12, p. 1612-1617, 2006. 
RUSAN, M. J. M.; HINNAWI, S.; ROUSAN, L. Long term effect of waste water irrigation of forage crops on soil and plant quality parameters. Desalinization, v. 215, n. 1-3, p. 143152, 2007. https://doi.org/10.1016/j.desal.2006.10.032

SRINIVASAN, V.; MAHESWARAPPA, H. P.; LAL, R. Long term effects of topsoil depth and amendments on particulate and non particulate carbon fractions in a Miamian soil of Central Ohio. Soil \& Tillage Research, v. 121, p. 10-17, 2012. https://doi.org/10.1016/j.still.2012.01.014

SUMNER, M. E. Sodic soils: New perspectives. Australian Journal of Soil Research, v. 31, n. 6, p. 683-750, 1993. https://doi.org/10.1071/SR9930683

VAN RAIJ, B. et al. (Eds.). Recomendações de Adubação e Calagem para o Estado de São Paulo. 2. ed. Campinas: IAC, 1997. 285 p. (Boletim técnico, 100).

WU, X.; DODGEN, L. K.; CONKLE, J. L.; GAN, J. Plant uptake of pharmaceutical and personal care products from recycled water and biosolids: A review. Science of the Total Environment, v. 536, p. 655-666, 2015. https://doi.org/10.1016/j.scitotenv.2015.07.129

YADAV, R.; GOYAL, B.; SHARMA, R. K.; S. DUBEY, S. K.; MINHAS, P. S. Post-irrigation impact of domestic sewage effluent on composition of soils, crops and groundwater: A case study. Environment International, v. 28, n. 6, p. 481-486, 2002. https://doi.org/10.1016/S0160-4120(02)00070-3 


Ambiente \& Água - An Interdisciplinary Journal of Applied Science
ISSN 1980-993X - doi:10.4136/1980-993X
www.ambi-agua.net
E-mail: ambi.agua@gmail.com

\title{
Changes in physicochemical and toxicological parameters of waters of Trincheira's River caused by road construction
}

\author{
ARTICLES doi:10.4136/ambi-agua.2360
}

Received: 17 Dec. 2018; Accepted: 08 May 2019

\author{
Juan Camilo Pires Salcedo Restrepo' ${ }^{1 D}$; Danieli Iara Antonelo ${ }^{2}$; \\ Ticiane Sauer Pokrywiecki $^{1}$; Ivane Benedetti Tonial $^{3}{ }^{(D}$; Fernando César Manosso ${ }^{1}{ }^{(D}$; \\ Igor Vivian de Almeida ${ }^{4}$; ; Veronica Elisa Pimenta Vicentini ${ }^{4}{ }^{\circledR}$; Elisângela Düsman $^{3 *(i)}$ \\ ${ }^{1}$ Universidade Tecnológica Federal do Paraná (UTFPR), Francisco Beltrão, PR, Brasil \\ Departamento Acadêmico de Engenharia Ambiental (DAEAM). E-mail: juan_cps_restrepo@hotmail.com, \\ ticiane@utfpr.edu.br,fmanosso@utfpr.edu.br \\ ${ }^{2}$ Universidade Tecnológica Federal do Paraná (UTFPR), Francisco Beltrão, PR, Brasil \\ Departamento Acadêmico de Engenharia Química (DAENQ). E-mail: dani_eli.antonelo@hotmail.com \\ ${ }^{3}$ Universidade Tecnológica Federal do Paraná (UTFPR), Francisco Beltrão, PR, Brasil \\ Departamento Acadêmico de Química e Biologia (DAQBI). \\ E-mail: ivane@utfpr.edu.br, edusman@utfpr.edu.br \\ ${ }^{4}$ Universidade Estadual de Maringá (UEM), Maringá, PR, Brasil \\ Departamento de Biotecnologia, Genética e Biologia Celular (DBC). \\ E-mail: igoralmeida.bio@gmail.com, arbvepv@wnet.com.br \\ "Corresponding author
}

\begin{abstract}
Road infrastructures can greatly affect natural areas. A trench and a roundabout were constructed in the city of Francisco Beltrão-Paraná-Brazil over a water body called Trincheira's River. The present study evaluated the quality of the waters of Trincheira's River, in physicochemical and toxicological terms, at four points along its course, during and after the trench and the roundabout construction. The results of the physicochemical analysis showed changes in some parameters analyzed near the road infrastructure, in particular, oils and greases, biochemical oxygen demand and dissolved oxygen. The immobility/mortality test with Artemia salina L. micro shellfish showed that none of the water at the collection points of the river was toxic. The cytotoxicity test with the bioindicator Allium cepa L. revealed no cytotoxic effect in the sample collection done during the road construction. However, after the finalization of the trench and the roundabout construction, a statistically significant increase in the percentage of the mitotic index at the road construction point was noticed. Therefore, awareness and regulatory measures are necessary to oversee activities on water bodies' shores and environs, to ensure a harmonious relationship between human activity and the ecosystem.
\end{abstract}

Keywords: Allium cepa L., Artemia salina L., bioindicators, water pollution, water quality.

\section{Alterações dos parâmetros físico-químicos e toxicológicos das águas do Rio da Trincheira afetadas por uma construção rodoviária}

\section{RESUMO}

Infraestruturas rodoviárias podem afetar áreas naturais com grande intensidade. Um trevo e uma trincheira foram construídas na cidade de Francisco Beltrão-Paraná-Brasil sobre um 
corpo d'água chamado Rio da Trincheira. O objetivo do presente estudo foi avaliar a qualidade de suas águas, em termos físico-químicos e toxicológicos, em quatro pontos ao longo de seu curso, durante e após a construção da trincheira e do trevo. Os resultados das análises físicoquímicas mostraram alterações em alguns parâmetros analisados, em especial, óleos e graxas, demanda bioquímica de oxigênio e oxigênio dissolvido, próximos à infraestrutura rodoviária. O teste de imobilidade/mortalidade com os microcrustáceos Artemia salina L. mostrou que nenhum dos pontos de coleta de água do rio foi tóxico. O teste de citotoxicidade com o bioindicador Allium cepa L. revelou que não houve efeito citotóxico na coleta da amostra durante a construção rodoviária. No entanto, após a finalização da construção da trincheira e do trevo, verificou-se um aumento estatisticamente significativo da percentagem do índice mitótico no ponto/local de construção da estrada. Portanto, medidas de conscientização e regulação devem ser necessárias para interferir nas atividades realizadas nas margens e nos corpos d'água, buscando uma relação harmoniosa entre as atividades humanas e todo o ecossistema.

Palavras-chave: Allium cepa L., Artemia salina L., bioindicadores, poluição da água, qualidade da água.

\section{INTRODUCTION}

Disorganized demographic growth, combined with a lack of urban planning and the irregular handling of agricultural products, can promote the degradation of water bodies. Buildings in general, but especially road infrastructures, affect natural areas with greater intensity than other processes of development, since they can lead to accidental spillages of chemical waste in rivers (Moraes and Santos, 2004), contaminating waters.

Solid or liquid waste from urban development, as well as from construction and demolition, has been the focus of studies in the past few years due to the environmental damage that they can cause. With regard to environmental damage, the lack of supervision of urban civil works and roads tends to worsen the impacts, compromising the quality not only of the soil and air but also of water bodies near urban facilities.

The pollution of a headwater mainly affects the physicochemical characteristics of the water, then systematically destroys the aquatic community, compromising the trophic chain and public health. However, the exclusive use of physical or physicochemical parameters to assess water quality (Von Sperling, 2005) has attracted criticism, in that a more ecosystemic approach is needed, requiring the application of biological assessment studies (Kuhlmann et al., 2001).

Bioindicators respond efficiently to the presence or absence of a contaminant, providing data related to the conditions of a specific environment (Frontalini and Coccioni, 2011). In Brazil, aquatic ecotoxicology has been used, along with chemical and physicochemical parameters, as a water quality parameter, constituting an important monitoring instrument of water resources (Tavares, 2014). In this sense, while chemical analyses identify and quantify concentration of toxic substances, toxicity tests assess the effect of these substances on biological systems.

Luíz et al. (2012) recommends that the toxic effect of a sample be evaluated by more than one representative species of aquatic biota, preferably belonging to different trophic levels of the food chain. In this scenario, the immobility/mortality test with Artemia salina L. micro shellfish and cytotoxicity test with the vegetable Allium cepa L. stand out. The test with A. salina is a method that has a good correlation with acute oral toxicity tests in vivo (Silva et al., 2010). Similarly, the test with A. cepa could be sensitive, and in addition has a positive correlation in prokaryotes and eukaryotes (Fatma et al., 2018), being indicative of risk to human health or the environment.

Rev. Ambient. Água vol. 14 n. 4, e2360 - Taubaté 2019 
Hence, the present study evaluated, through physicochemical analysis and ecotoxicological tests with A. salina and $A$. cepa, the influence of urban construction activities on the water quality of Trincheira's River in the municipality of Francisco Beltrão - Paraná, Brazil.

\section{MATERIAL AND METHODS}

\subsection{Study Area}

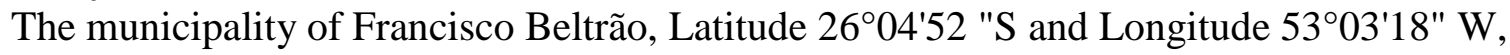
located in the southwest region of the State of Paraná - Brazil (Figure 1), is undergoing urban expansion (Francisco Beltrão, 2012).

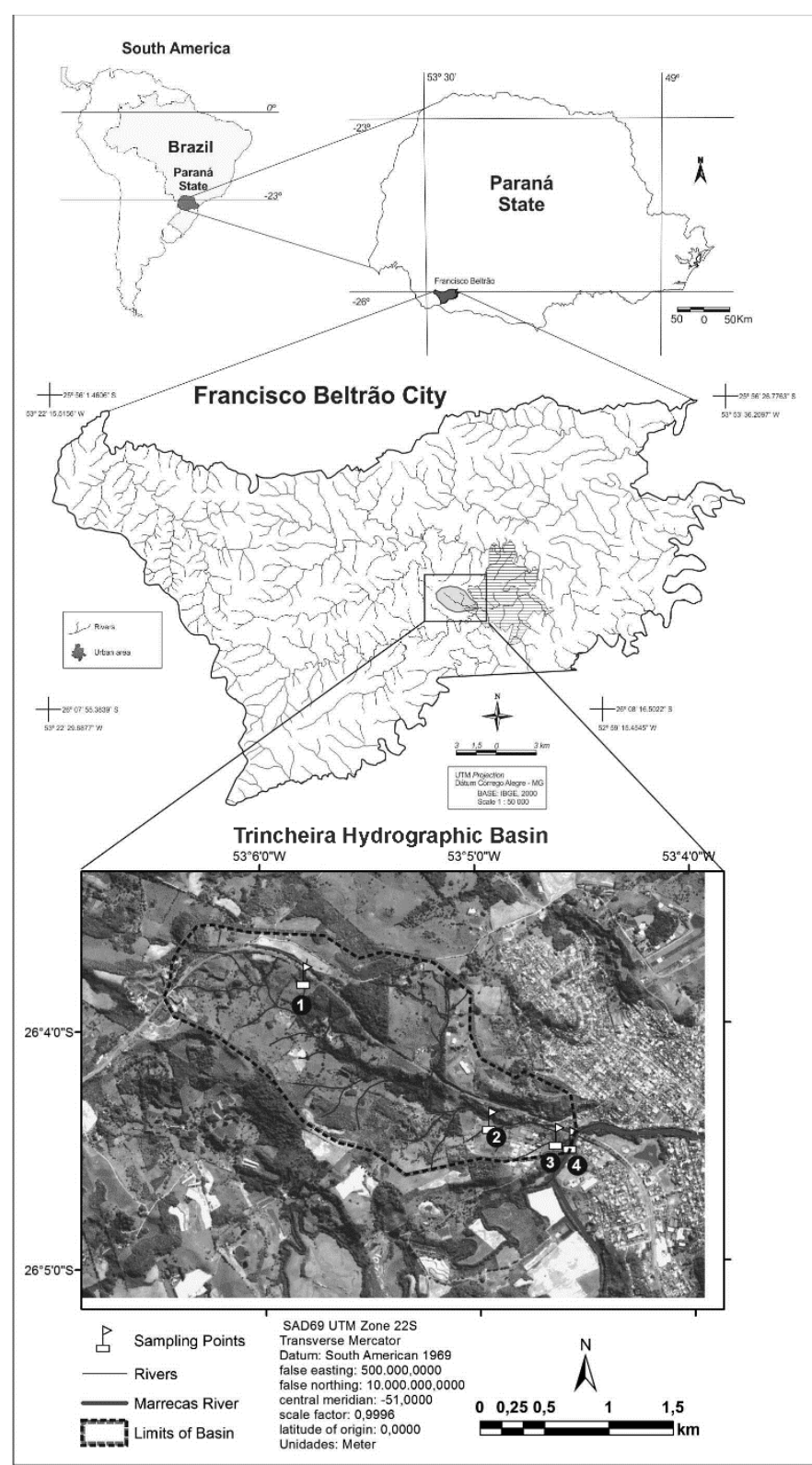

Figure 1. Location of the municipality of Francisco Beltrão-Paraná, Brazil. The river basin area contributing to the river headwater contribution of Trincheira's River (area under study) and its water-sample collection points: River headwater (P1); Residential condominium (P2); Place where the river was channeled for road construction (P3); River mouth (P4). 
The region of the study (the watershed basin of the Trincheira's River) is characterized by agricultural, urban and industrial activities, with an emphasis on beef and dairy cattle, construction of residential condominiums and mining. This headwater has a significant importance to the region, since it supplies the small farms for livestock watering, aquaculture, and even human consumption. In order to facilitate access to the county, a trench and roundabout were built, at the same place, in the West region of the municipality. This required rock demolition, as well as earth work and the insertion of a drain pipeline, to conduct the water of the Trincheira's River, the course of which was changed close to its mouth at Marrecas's river.

The daily flow of trucks (cargo/transport), buses (urban, intermunicipal and state), agricultural machinery and other automobiles is intense. The roundabout directs the flow of vehicles to an industrial district, the federal university, the agricultural school and the other neighborhoods around the city.

\subsection{Sampling}

The water samples were collected during October 2014 and after April 2015, the trench and the roundabout construction. In October 2014, the total monthly rainfall was approximately 125 millimeters, and in April 2015 it was 45 millimeters in the city of Francisco Beltrão and the surrounding region (IAPAR, 2016).

Four sampling points were selected along Trincheira's River (Figure 1): Point 01 Headwater of the river $\left(6^{\circ} 03^{\prime} 46.4^{\prime \prime} \mathrm{S} ; 53^{\circ} 05^{\prime} 50.3^{\prime \prime} \mathrm{W}\right)$; Point 02 - Next to a residential condominium $\left(26^{\circ} 04^{\prime} 23.9^{\prime \prime} \mathrm{S} ; 5^{\circ} 04^{\prime} 56.2^{\prime \prime} \mathrm{W}\right)$; Point 3 - The trench and the roundabout construction $\left(26^{\circ} 04^{\prime} 27.5^{\prime \prime} \mathrm{S} ; 5^{\circ} 04^{\prime} 37.9^{\prime \prime} \mathrm{W}\right)$; and Point 04 - The river mouth (26 $04^{\prime} 29.3^{\prime \prime} \mathrm{S}$; $\left.53^{\circ} 04^{\prime} 37.2^{\prime \prime} \mathrm{W}\right)$.

The collection and preservation/storage of water samples were carried out according to instructions and methods contained in "Standard Methods" (APHA et al., 2012). The samples were collected with the aid of a plastic bucket, in places of difficult access to the middle of the river water stream, and stored in clean plastic bottles. Where possible, the plastic bottles were immersed at the point of collection in the river, about $30 \mathrm{~cm}$ deep. The parameters of $\mathrm{pH}$, Temperature (T), chemical oxygen demand (COD), biochemical oxygen demand (BOD) and dissolved oxygen (DO) were analyzed in the laboratory immediately after collection. For the analysis of ammonia nitrogen, total phosphorus, oils and greases and toxicity, the bottles with samples were stored in a refrigerator at $10^{\circ} \mathrm{C}$ for up to 1 week or frozen $\left(\mathrm{T} \leq 4^{\circ} \mathrm{C}\right)$ for subsequent analysis. Afterwards, the bottles were thawed until they reached room temperature.

\subsection{Physicochemical parameters}

The analysis of physicochemical parameters of the water samples of the Trincheira's River followed the methodologies established by the "Standard Methods" (APHA et al., 2012). The following parameters were evaluated in triplicate: $\mathrm{pH}$, chemical oxygen demand, biochemical oxygen demand, dissolved oxygen, ammoniacal nitrogen (ammonia-N), total phosphorus, oils and greases and temperature.

\subsection{Immobility/Mortality tests}

The toxicity test was performed with A. salina L. by the method proposed by Guerra (2001), with modifications based on ABNT NBR 13373 (2010). Ten nauplii of A. salina, in instar stages 2-3, were transferred to test tubes containing $2 \mathrm{~mL}$ of samples from the different points of Trincheira's River, and diluted in a saline solution ( $30 \mathrm{~g}$ of sea salt per L distilled water) in the following concentrations: $100 \%, 50 \%, 25 \%, 12.5 \%, 6.2 \%$ and $3.1 \%$, in order to determine the critical range, based on the average number of dead nauplii per concentration of the river's water, based on ABNT NBR 13373 (2010). The negative control group contained only $2 \mathrm{~mL}$ 
of saline solution $\left(\mathrm{CO}^{-} 1\right)$ or $2 \mathrm{~mL}$ of mineral water $\left(\mathrm{CO}^{-} 2\right)$, to confirm the effect of river water and not saline or sweet. Positive control $\left(\mathrm{CO}^{+}\right)$was performed with $0.016 \mu \mathrm{L}$ of methyl methanesulfonate per $\mathrm{mL}$ of mineral water. After 24 hours of incubation (tubes at $25 \pm 1{ }^{\circ} \mathrm{C}$ ), the number of dead/immobility nauplii was checked for each replicate to calculate the mean number of dead/immobile nauplii, thus determining the toxicity.

\subsection{Cytotoxicity and mutagenicity tests}

Cytotoxicity and mutagenicity tests were assessed using the meristematic cells of the root of $A$. серa L. (onion), prepared by the Feulgen reaction and stained with the Schiff reagent (Fiskesjö, 1985).

First, the onion bulbs were cleaned and placed to generate roots in containers containing filtered, aerated water, in a dark room, with temperature control of $25 \pm 2^{\circ} \mathrm{C}$. Five onions were used for each treatment sample group. Before each treatment, two roots of each onion were collected, to serve as the control of the bulb (Co-Oh). Thereafter, the roots were exposed to treatments with water samples from Trincheira's River and $0.04 \mathrm{mg}$ of cyclophosphamide/mL filtered water (positive control $-\mathrm{CO}^{+}$), for 24 hours $(\mathrm{Tr}-24 \mathrm{~h}$ ), according to the proposal proposed by Fiskesjö (1985). The bulbs were then placed again in filtered water, to recover themselves from any damage for 24 hours $(\mathrm{Re}-24 \mathrm{~h})$. The negative control $\left(\mathrm{CO}^{-}\right)$remained all the time in the filtered water.

The roots collected during the three days of collection $(\mathrm{Co}-0 \mathrm{~h}, \mathrm{Tr}-24 \mathrm{~h}, \mathrm{Re}-24 \mathrm{~h})$ of all treatments (Points 1, 2, 3, 4, $\mathrm{CO}^{+}$and $\mathrm{CO}^{-}$) were fixed, hydrolyzed with hydrochloric acid $(\mathrm{HCl}$ $1 \mathrm{~N}$ at $60^{\circ} \mathrm{C}$ for 10 minutes) and colored with Schiff reagent (45 minutes in the dark). Then, the meristematic region of onion roots was collected, stained with acetic orcein and crushed to produce the blades.

The blades were analyzed using the blind test in light microscopes $(40 \mathrm{x})$. One thousand cells were counted from each onion, differentiating them according to the mitotic phases (Interphase, Prophase, Metaphase, Anaphase, Telophase), to determine the percentage of Mitotic index (MI\%) from each sampling time of the evaluated groups, using the following formula: $\mathrm{MI} \%=$ (number of dividing cells/total number of cells analyzed) $\mathrm{x} 100$. The cells were also analyzed observing structural changes, like colchicine metaphase or disorganized metaphase, disorganized anaphase or with chromosomes loss, micronucleus and others.

\subsection{Statistical analysis}

The average of physicochemical analyses, the average of immobility (Immobility test) and the average of MIs (Cytotoxicity test) were performed by the Tukey test $(\alpha=0.05 ; n=3, n=4$ and $\mathrm{n}=5$, respectively).

\section{RESULTS AND DISCUSSION}

The $\mathrm{pH}$ values (Table 1) found in the river's water samples, although with a statistical difference $(\mathrm{p}<0.05)$ between points and also in the periods during and after the trench and roundabout construction, are in accordance with the limit (6.0-9.0) established by CONAMA legislation $\mathrm{N}^{\circ} 357$ (2005) for the class of Trincheira's River (Class II of fresh water). According to Von Sperling (2005), aquatic organisms are usually adapted to conditions of neutrality ( $\mathrm{pH}$ $\approx 7$ ), and sudden changes of the water's $\mathrm{pH}$ may lead to the extinction of aquatic biota. In the present study, $\mathrm{pH}$ ranged from 6.5 to 7.2 (slight acid to neutral), not being considered an abrupt variation (Avvannavar and Shrihari, 2008) or an endangering value to the aquatic ecosystem (Yalçuk and Postalcığlu, 2015). According to Gupta et al. (2017), the variations of pH can be attributed to the different seasons and climates of the year during the samplings, resulting in a variation in the concentration of $\mathrm{CO}_{2}$ incorporated in river waters. Similar $\mathrm{pH}$ values were obtained by Gan et al. (2008), to evaluate the $\mathrm{pH}$ of superficial water runoff of some sampling

Rev. Ambient. Água vol. 14 n. 4, e2360 - Taubaté 2019 
points on highways in the Pearl River Basin (Guangzhou-Southern China).

The concentration of total phosphorus (Table 1) also presented significant difference ( $\mathrm{p}<0.05$ ) when compared with the collecting points, during and after the ending of construction, with values that varied from $0.013(\mathrm{P} 1)$ to $0.033 \mathrm{mg} \mathrm{L}^{-1}(\mathrm{P} 2)$, being all values below what is recommended in the legislation (0.1 mg L-1) (CONAMA, 2005). The highest value for the concentration of phosphorus at Point 2 can be directly related to the $\mathrm{pH}$, because, according to Silva et al. (2003), lower values of $\mathrm{pH}$ favor the dissolution of substances, increasing their concentrations in the aqueous medium. Other factors that may explain the low phosphorus concentration along the river are the water's flow at the points of collection (lotic stretch), low incidence of rural residences and the absence of agricultural fields. According to Kibena et al. (2014) and Rahman et al. (2011), the increase in the concentrations of nutrients $\left(\mathrm{NO}_{3}, \mathrm{NH}_{3}\right.$, and $\left.\mathrm{PO}_{4}\right)$ in surface water bodies tends to be related to the presence of fertilizers, synthetic substances, domestic effluents and the decrease of the water's flow (lentic stretches).

Table 1. Average and standard deviation of physicochemical parameters analyzed in triplicate for the different points of the Trincheira's River, during and after road infrastructure construction.

\begin{tabular}{|c|c|c|c|c|c|}
\hline \multirow{2}{*}{$\begin{array}{l}\text { Collecting } \\
\text { Points }\end{array}$} & \multirow{2}{*}{$\begin{array}{c}\text { Time of } \\
\text { Collection }\end{array}$} & \multicolumn{4}{|c|}{ Physicochemical Parameters } \\
\hline & & pH & $\begin{array}{l}\text { Ammonia- } \\
\mathbf{N}\left(\mathrm{mg} \mathrm{L}^{-1}\right)\end{array}$ & $\begin{array}{c}\text { Total Phosphorus } \\
\left(\mathrm{mg} \mathrm{L}^{-1}\right)\end{array}$ & $\begin{array}{c}\text { Temperature } \\
\left({ }^{\circ} \mathrm{C}\right)\end{array}$ \\
\hline \multirow{2}{*}{ P1 } & During & $6.64 \pm 0.01^{\mathrm{aA}}$ & VA & $0.016 \pm 0.001^{\mathrm{aA}}$ & $26.71 \pm 0.01^{\mathrm{aA}}$ \\
\hline & After & $7.06 \pm 0.09^{\mathrm{aB}}$ & VA & $0.013 \pm 0.001^{\mathrm{aB}}$ & $23.13 \pm 0.05^{\mathrm{aB}}$ \\
\hline \multirow{2}{*}{$\mathrm{P} 2$} & During & $6.92 \pm 0.02^{\mathrm{bA}}$ & VA & $0.023 \pm 0.001^{\mathrm{bA}}$ & $26.57 \pm 0.05^{\mathrm{abA}}$ \\
\hline & After & $6.57 \pm 0.05^{\mathrm{bB}}$ & VA & $0.033 \pm 0.001^{\mathrm{bB} *}$ & $23.61 \pm 0.17^{\mathrm{bB}}$ \\
\hline \multirow{2}{*}{ P3 } & During & $6.87 \pm 0.02^{\mathrm{bA}}$ & VA & $0.020 \pm 0.001^{\mathrm{cA}}$ & $26.33 \pm 0.05^{\mathrm{bA}}$ \\
\hline & After & $7.07 \pm 0.01^{\mathrm{aB}}$ & VA & $0.023 \pm 0.001^{\mathrm{cB}}$ & $23.43 \pm 0.11^{\mathrm{bB}}$ \\
\hline \multirow{2}{*}{ P4 } & During & $7.05 \pm 0.03^{\mathrm{cA}}$ & VA & $0.020 \pm 0.001^{\mathrm{cA}}$ & $26.51 \pm 0.00^{\mathrm{abA}}$ \\
\hline & After & $7.19 \pm 0.01^{\mathrm{cB}}$ & VA & $0.026 \pm 0.001^{\mathrm{dB}}$ & $23.33 \pm 0.15^{\mathrm{abB}}$ \\
\hline \multicolumn{2}{|c|}{ Conama No 357/2005 } & $6.00-9.01$ & $\leq 3.7$ & $\leq 0.1$ & - \\
\hline
\end{tabular}

P1: River headwater; P2: Residential condominium; P3: The trench and the roundabout construction; P4: River mouth. VA: Virtually Absent.

Values with the same letter do not differ statistically among themselves; lowercase is used for the comparison among the four sampling points at each collection time, and uppercase for the comparison between the times of each collection point by Tukey test with a significance level of $5 \%, \mathrm{n}=3$.

BOD is an indicator parameter related to the amount of oxygen required in an aquatic environment for a microorganism's respiration over the consumption of organic substances, which are directly associated with the presence of animal and food waste or residential/industrial discharge of untreated sewage introduced into the aquatic environment (Oliveira et al., 2012). In this study, the values ranged from 12.78 to $68.33 \mathrm{mg} \mathrm{L}^{-1 ;} \mathrm{O}_{2}$ differed statistically $(\mathrm{p}<0.05)$ (Figure 2$)$ between the sample points. During the trench and roundabout construction, it could be seen that the values of the BOD, the DO and oils and greases (Figure 2) at any collection point were in disagreement with the values established by legislation $\left(\mathrm{BOD} \leq 5 \mathrm{mg} \mathrm{L}^{-1} \mathrm{O}_{2} ; \mathrm{DO} \geq 5 \mathrm{mg} \mathrm{L}^{-1} \mathrm{O}_{2}\right.$; oils and greases = virtually absent $)($ CONAMA, 2005). A similar phenomenon was observed by Sekabira et al. (2010), which showed values higher than the limit of local legislation (BOD $\leq 50 \mathrm{mg} \mathrm{L}^{-1}$ - National Environment Management Authority - NEMA), mainly due to the discharge of industrial effluents in the Nakivubo stream (Kampala - Uganda). 


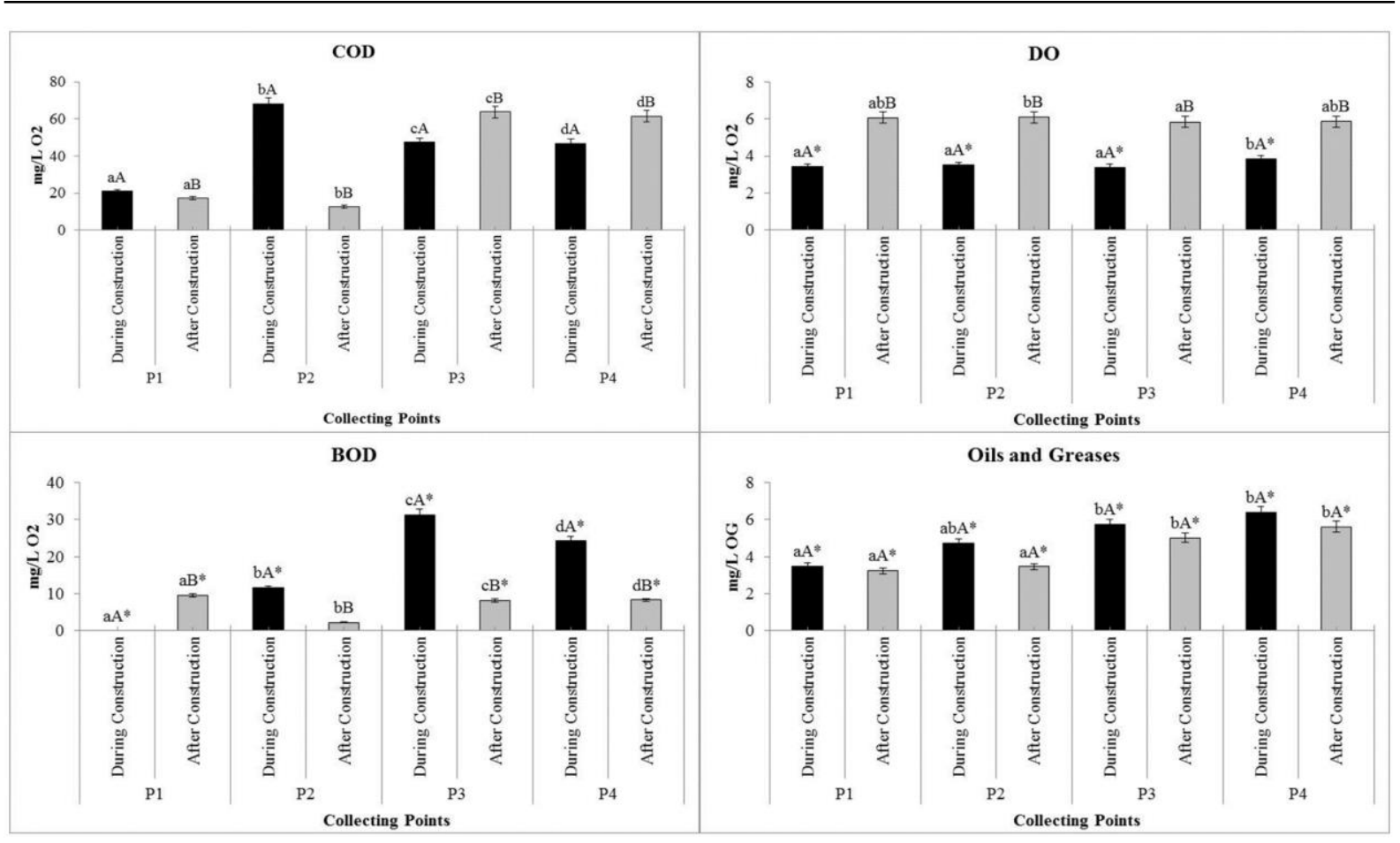

Figure 2. Average and standard deviation of physicochemical parameters analyzed for the different points of the Trincheira's River, during and after the construction of the road infrastructure.

P1: River headwater; P2: Residential condominium; P3: The construction site of the trench and roundabout; P4: River mouth. COD: chemical oxygen demand; BOD: biochemical oxygen demand; DO: dissolved oxygen. * Data different from those established by law $\mathrm{N}^{\circ} 357$ of 2005 from CONAMA for Class II. Values with the same letter do not differ statistically among themselves; lowercase is used for comparison among the four sampling points in each collection time, and uppercase for the comparison between the times of each collection point by Tukey test with a significance level of $5 \%$.

The lowest levels of DO $\left(3.4-3.87 \mathrm{mg} \mathrm{L}^{-1}\right)$ related to the presence of organic matter or similar synthetic compounds in the river waters. A similar study carried out in the Dourados and Brilhante Rivers by Sposito et al. (2019) related the low OD values found (3.66 - $4.86 \mathrm{mg} \mathrm{L}^{-1} \mathrm{O} 2$ ) to the intense urbanization process (domestic effluent disposal) and agriculture (pesticides and agrochemicals). Arpine and Gayane (2016), studying the water of river Akhuryan (Armenia), observed higher DO values $\left(10.3 \mathrm{mg} \mathrm{L}^{-1} \mathrm{O}_{2}\right)$ and lower BOD $\left(2.8 \mathrm{mg} \mathrm{L}^{-1} \mathrm{O}_{2}\right)$ and $\mathrm{COD}\left(10.5 \mathrm{mg} \mathrm{L}^{-1} \mathrm{O}_{2}\right)$ values than those of the present study, aforenamed. However, the Akhuryan waters possess a great potential for self-depuration, because its riverbed features a shapeless rocky profile when, adversely, the Trincheira's River waters has a reduced and uniform flow rate. In the present study, it was possible to verify a significant increase of the DO concentration after the roundabout construction (Figure 2), setting the values according those recommended by CONAMA (2005). This increase in the DO concentration is possibly due to a reduction in the release of organic substances, such as oils and greases, after the work ended.

According to CETESB (2009), the decomposition process of oils and greases, could reduce dissolved oxygen and the contact surface between the water surface and the atmospheric air. In addition, the increase of BOD and COD concentration could lead to aesthetic and organoleptic problems on the course of the river as well as scum formation, eutrophication and bad smell.

According to Brazilian legislation (CONAMA, 2005), the presence of oils and greases in hydrous bodies should be null. In the present study, these compound were found at all sampled points, with contents ranging from 3.24 to $6.40 \mathrm{mg} \mathrm{L}^{-1}$ with significant difference $(\mathrm{p}<0.05)$ between the sampling points P1, P3 and P4 (Figure 2). This presence could imply a source of oil or synthetic derivative contamination, indicating pollution from urban waste, sewage 
disposal and accidental spills. Katukiza et al. (2015) have shown that domestic effluent water charges in the Bwaise III (Kampala - Uganda) showed concentrations of oils and greases above that established by local legislation $\left(10 \mathrm{mg} \mathrm{L}^{-1}\right)$, as well as the situation found in the present study. Highway vehicles release particulates and synthetic lubricants, which are leached by surface runoff during precipitation events until they reach the river. Van Bohemen and Janssen Van de Laak (2003) found similar values for the concentration of oils and derivatives (3.0 - 8.0 mg L-1) in runoff waters on national, provincial and municipal roads in Holanda. Moreover, during the roundabout construction, there was a high incidence of large machinery moviment, such as excavators, bulldozers and dump trucks, which could have accidentally spilled oil, grease, and tar.

Physicochemical data corroborate with those found in the immobility/mortality test with the bioindicator A. salina (Figure 3). The waters of Trincheira's River had a high mortality rate at the point of the trench and the roundabout construction after the end of the construction (P3) (17\% mortality) (Figure 3). Maddela et al. (2016), studying the removal of petroleum hydrocarbons, showed that the higher the concentration of these petrochemical derivatives, the greater was the mortality ( $\approx 33,5 \%$ - exposure for $24 \mathrm{~h})$ of the $A$. salina shellfish.

The statistical data from the immobility/mortality test did not show significant toxicological effect of the water samples, during or after the construction of road infrastructure, because the mortality of organisms exposed to water samples of all four points of the river was statistically similar to negative control mortality.

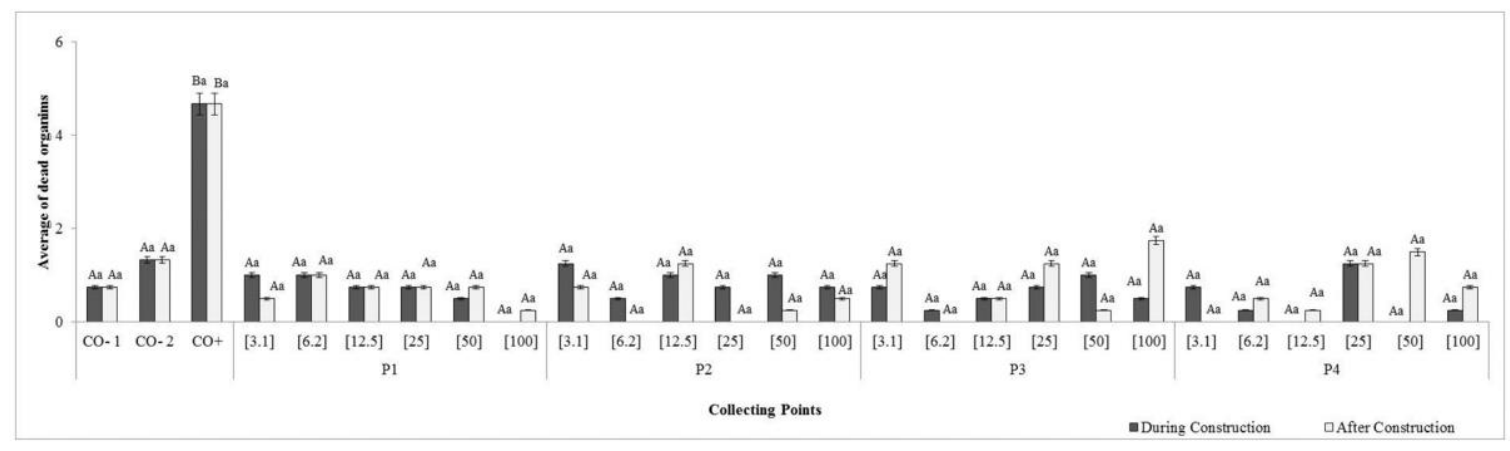

Figure 3. Average numbers of dead organisms obtained during and after the road infrastructure construction for different concentrations of water samples from Trincheira's River. $\mathrm{CO}^{-} 1$ : Negative control with saline solution. $\mathrm{CO}^{-} 2$ : Negative control with mineral water. $\mathrm{CO}^{+}$: Positive control. P1: River headwater; P2: Residential condominium; P3: The construction site of the trench and roundabout; $\mathrm{P} 4$ : The river mouth.

Percentages with the same letters do not differ statistically among themselves; uppercase is used for comparison within the same collection time, and lowercase for comparison between the two times of collection, by Tukey test with a significance level of $5 \%$.

Additionally, changes in toxicity were not observed during or after the road construction for any evaluated point, because the average number of dead/still organisms was statistically similar. Similar results were found by Vaz et al. (2010), who studied the toxicity of Babitonga Bay (Santa Catarina, Brazil), also with the A. salina bioindicator. The data showed that the vast majority of the evaluated points was not toxic to the micro shellfish.

Components in gasoline and diesel fuel, such as benzene and benzo (a) pyrene, are carcinogenic compounds, while the toluene, ethylbenzene, and xylene are classified as toxic. However, when some of these derivatives are poured directly into the water, they have a rapid volatilization, with little tendency to adsorb sediments or to hydrolyze (Finotti et al. 2001), which possibly has resulted in lower acute toxicity of water samples from the Trincheira's River, contaminated by oils and greases. 
No cytotoxicity was observed by $A$. cepa bioindicator during the trench and roundabout construction. Data in Figure 4 show that there was no statistical difference between the mitotic index of the negative control at the time of sampling (Co-Oh, Tr-24h, and Re-24 h) and the groups treated with water samples collected from all points. When sampling times within the same group were compared, control or treaty, no statistical difference was found.

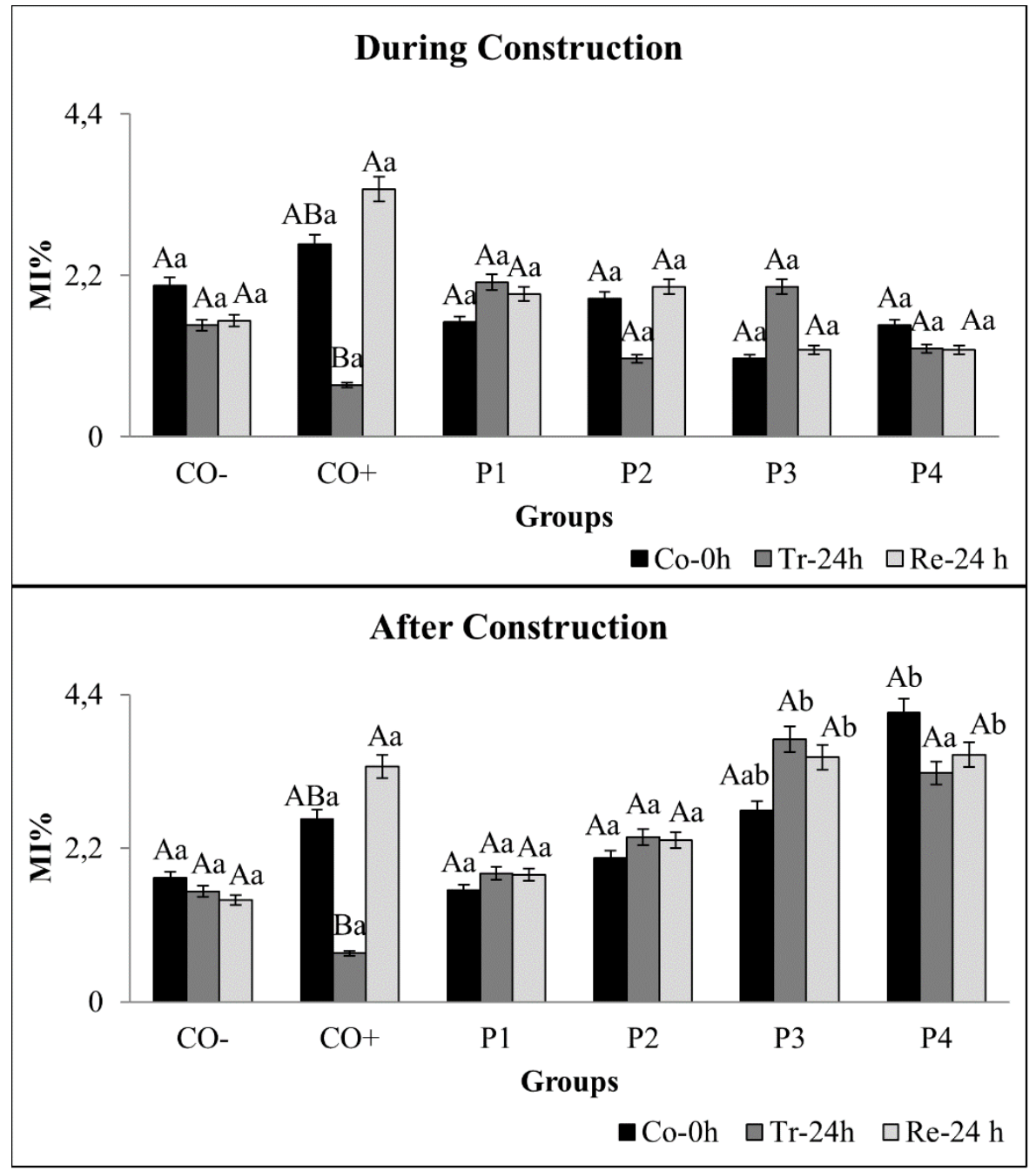

Figure 4. Percentage of Mitotic Indexes (MI) obtained during and after the construction of road infrastructure for water samples from Trincheira's River. $\mathrm{CO}^{-}$: Negative control. $\mathrm{CO}^{+}$: Positive control. P1: River headwater; P2: Residential condominium; P3: The trench and roundabout construction; P4: The river mouth. Sampling time: 0 time $=\mathrm{Co}-0 \mathrm{~h}$, Treatment 24 hours $=\mathrm{Tr}$ $24 \mathrm{~h}$, Recovery 24 hours $=\mathrm{Re}-24 \mathrm{~h}$. Percentages with the same three letters do not differ statistically among themselves; uppercase is used for the comparison between three sampling times within the same group or control, lowercase for comparison between each sampling time of the negative control with the same time of each group treated, by Tukey test with a significance level of 5\%.

The absence of A. cepa cytotoxicity, was also found in waters contaminated with petrochemical derivatives (leaked from a pipeline) (Leme and Marin-Morales, 2008) and effluents from refineries (Gupta and Ahmad, 2012). Similar results, using the same test system as the present study, were found on the surface waters of the Sava River (Croatia) (Radic et al., 2010), on the waters from Ribeirões Varginha River (Califórnia-Paraná-Brazil) and Tabatinga

\section{IPABH}

Rev. Ambient. Água vol. 14 n. 4, e2360 - Taubaté 2019 
River (Mandaguari-Paraná-Brasil) (Ferreira et al., 2012), and on the waters from the Peixe River collected in the cities of Garça, Tupã, Flórida Paulista and Ouro Verde (São Paulo-Brazil) (Costa et al., 2015), which also received agricultural, industrial and urban effluents along their courses. Morphological changes and chromosomal alterations were also not observed when exposed to the waters of Trincheira's River, similar to work by Ferreira et al. (2012).

After the road construction, the data of cytotoxicity (Figure 4) show that the groups treated with the waters from Trincheira's River showed percentages of mitotic indexes progressively larger, from 1 to $4(\mathrm{P} 1=1.84 \%, \mathrm{P} 2=2.36 \%, \mathrm{P} 3=4.00 \%, \mathrm{P} 4=3.28 \%)$. However, only Point 3 (site of the trench and roundabout construction) (24 hours) showed increases in the percentage of mitotic index statistically different from the negative control $(24$ hours $=1.58 \%)$ and P1. The values of physicochemical analysis were supported by those data. Points 3 and 4 presented the highest values of COD and mitotic indexes and smaller levels of DO when compared to other collection points.

The COD of Points 3 and 4 (site of the road construction and the river mouth) presented elevated levels from the first to the second collection (Figure 2). The change from wet weather to the dry weather could cause an increase in the level of contaminants, possibly, due to the decrease in the flow of the river (Kibena et al., 2014). After the roundabout construction, the water sampling was performed during a drier season (Autumn), resulting in a lower flow rate when compared to the headwater (first collection) at the moment the Trincheira's River was being piped in.

Similar to the studied data, the evaluation of Quatorze River, located in the rural municipality of Francisco Beltrão, showed that three points of this river were not cytotoxic to the A. сера bioindicator. One point presented statistical increase of cell proliferation and one point a greater organic load in the physicochemical analyses (Düsman et al., 2014). Gomes et al. (2015) also used the. A. cepa to study the cytotoxicity of the Guandu River (Rio de JaneiroBrazil), contaminated by urban and industrial effluents, and there were increased percentages of mitotic indexes of the onions exposed to these waters.

\section{CONCLUSIONS}

The data from this study indicate changes in some physicochemical parameters analyzed; in particular, oils and greases, biochemical oxygen demand and dissolved oxygen, close to the road infrastructure. Toxicology tests showed an increase in the number of dead A. salina and in the percentage of mitotic index of the A. cepa roots, from the headwater to the river mouth. It was most evident at the collection point of the trench and the roundabout construction for both bioindicators.

Therefore, awareness and regulatory measures are necessary to oversee activities performed on the water bodies' shores and environs, to ensure a harmonious relationship between human activities and the ecosystem.

\section{ACKNOWLEDGEMENTS}

To the Federal Technological University of Paraná, Francisco Beltrão-Paraná-Brazil.

\section{REFERENCES}

ABNT. Nbr 13373: Ecotoxicologia Aquática - Toxicidade crônica - Método de ensaio com Ceriodaphnia Ssp (Crustacea, Cladocera). 3. ed. Rio de Janeiro, 2010. 18 p.

APHA; AWWA; WEF. Standard Methods for the examination of water and wastewater. $22^{\text {nd }}$ ed. Washington, 2012.

Rev. Ambient. Água vol. 14 n. 4, e2360 - Taubaté 2019 
ARPINE, H.; GAYANE, S. Determination of background concentrations of hydrochemical parameters and water quality assessment in the Akhuryan river basin (Armenia). Physics and Chemistry of the Earth, v. 94, p. 2-9, 2016. https://doi.org/10.1016/j.pce.2016.03.011

AVVANNAVAR, S. M.; SHRIHARI, S. Evaluation of water quality index for drinking purposes for river Netravathi, Mangalore, South India. Environmental Monitoring and Assessment, v. 143, p. 279-290, 2008. https://doi.org/10.1007/s10661-007-9977-7

CETESB. Qualidade das águas interiores do estado de São Paulo. 2009. Available at: http://www.cetesb.sp.gov.br/agua/aguas-superficiais/35-publicacoes-/-relatorios. Access in: Dec. 2018.

CONAMA (Brasil). Resolução n 357 de 17 de março de 2005. Dispõe sobre a classificação dos corpos de água e diretrizes ambientais para o seu enquadramento, bem como estabelece as condições e padrões de lançamento de efluentes, e dá outras providências. Diário Oficial [da] União: seção 1, Brasília, DF, n. 053, p. 58-63, 18 mar. 2005.

COSTA, A. C.; DOMINGUES, G.; DÜSMAN, E.; ALMEIDA, I. V.; VICENTINI, V. E. P. V. Citotoxicidade das águas do Rio do Peixe (São Paulo-Brasil), em células meristemáticas de raiz de Allium cepa L. Bioscience Journal, v. 31, n. 1, p. 248-258, 2015. https://doi.org/10.14393/BJ-v31n1a2015-15069

DÜSMAN, E.; LUZZA, M.; SAVEGNAGO, L.; LAUXEN, D.; VICENTINI, V. E. P., TONIAL, I. B.; SAUER, T. P. Allium cepa L. as a bioindicator to measure cytotoxicity of surface water of the Quatorze river, located in Francisco Beltrão, Paraná, Brazil. Environmental Monitoring and Assessment, v. 186, p. 1793-1800, 2014. https://doi.org/10.1007/s10661-013-3493-8

FATMA, F.; VERMA, S.; KAMAL, A.; SRIVASTAVA, A. Monitoring of morphotoxic, cytotoxic and genotoxic potential of mancozeb using Allium assay. Chemosphere, v. 195, p. 864-870, 2018. https://doi.org/10.1016/j.chemosphere.2017.12.052

FERREIRA, C. F.; FRUEH, A. B.; DUSMAN, E.; HECK, M. C.; VICENTINI, V. E. P. Avaliação da citotoxicidade das águas dos ribeirões varginha (Califórnia-Pr) e Tabatinga (Mandaguari-Pr), em Allium cepa L. Sabios-Revista Saúde e Biologia, v. 7, n. 2, p. 46$54,2012$.

FINOTTI, A. R.; RODRIGUEZ, M. T. R.; CAICEDO, N. O. L. Contaminações subterrâneas com combustíveis derivados de petróleo: Toxicidade e a legislação brasileira. Revista Brasileira De Recursos Hídricos, v. 6, n. 2, p. 29-46, 2001.

FISKESJÖ, G. The Allium test as a standard in environmental monitoring. Hereditas, v. 102, n. 1, p. 99-112, 1985. https://doi.org/10.1111/j.1601-5223.1985.tb00471.x

FRANCISCO BELTRÃO. Perfil do Município. Francisco Beltrão, 2012. Available at: http://franciscobeltrao.pr.gov.br/departamentos/turismo/a-secretaria/economiatecnologia/perfil-do-municipio/attachment/perfil-do-municipio-2012-2/. Access in: Apr. 2016 .

FRONTALINI, F.; COCCIONI, R. Benthic Foraminífera as bioindicators of pollution: A review of italian research over the last three decades. Revue ae Micropaleontology, v. 54, n. 2, p. 115-127, 2011. https://doi.org/10.1016/j.revmic.2011.03.001

Rev. Ambient. Água vol. 14 n. 4, e2360 - Taubaté 2019 
GAN, H.; ZHUO, M.; LI, D.; ZHOU, Y. Quality characterization and impact assessment of highway runoff in the urban and rural area of Guangzhou, China. Environmental Monitoring and Assessment, v. 140, p. 147-159, 2008. https://doi.org/10.1007/s10661007-9856-2

GOMES, J. V.; TEIXEIRA, J. T. S.; LIMA, V. M.; BORBA, H. R. Induction of cytotoxic and genotoxic effects of Guandu river waters in the Allium cepa system. Revista Ambiente \& Água, v. 10, n. 1, p. 48-58, 2015. http://dx.doi.org/10.4136/ambi-agua.1487

GUERRA, R. Ecotoxicological and chemical evaluation of phenolic compounds in industrial effluents. Chemosphere, v. 44, n. 8, p. 1737-1747, 2001. https://doi.org/10.1016/S00456535(00)00562-2

GUPTA, A. K.; AHMAD, M. Assessment of the cytotoxic and genotoxic potential of refinery waste effluent using plant, animal, and bacterial systems. Journal of Hazardous Materials, v. 201-202, p. 92-99, 2012. https://doi.org/10.1016/j.jhazmat.2011.11.044

GUPTA, N.; PANDEY, P.; HUSSAIN, P. Effect of physicochemical and biological parameters on the quality of river water of Narmada, Madhya Pradesh, India. Water Science, v. 31, p. 11-23, 2017. https://doi.org/10.1016/j.wsj.2017.03.002

IAPAR. Agrometeorologia - Dados pluviométricos diários. Available at: http://www.iapar.br. Access in: Nov. 2016.

KATUKIZA, A. Y.; RONTELTAP, M.; NIWAGABA, C. B.; KANSIIME, F.; LENS, P. N. L. Grey water characterisation and pollutant loads in an urban slum. International Journal of Environmental Science and Technology, v. 12, p. 423-436, 2015. https://doi.org/10.1007/s13762-013-0451-5

KIBENA, J.; NHAPI, I.; GUMINDOGA, W. Assessing the relationship between water quality parameters and changes in land-use patterns in the upper Manyame river, Zimbabwe. Physics and Chemistry of The Earth, v. 67-69, p. 153-163, 2014. https://doi.org/10.1016/j.pce.2013.09.017

KUHLMANN, M. L.; BRANDIMARTE, A. L.; SHIMIZU, G. Y.; ANAYA, M. Invertebrados bentônicos como indicadores de impactos antrópicos sobre ecossistemas aquáticos continentais. In: MAIA, N. B.; MARTOS, B.; HENRY, L. (Eds). Indicadores ambientais: Conceitos e aplicações. São Paulo: Educ/Comped/Inep, 2001.

LEME, D. M.; MARIN-MORALES, M. A. Chromosome aberration and micronucleus frequencies in Allium cepa cells exposed to petroleum polluted water-a case study. $\begin{array}{llllll}\text { Mutation } & \text { Research, } & \text { v. } & 650, & \text { p. } & 80-86,\end{array}$ https://doi.org/10.1016/j.mrgentox.2007.10.006

LUÍZ, Â. M. E.; PINTO, M. L. C.; SCHEFFER, E. Parâmetros de cor e turbidez relacionados aos usos do solo e à morfometria da bacia hidrográfica do Rio Taquaral, São Mateus do Sul-Pr. Revista Caminhos da Geografia, v. 24, p. 290-310, 2012.

MADDELA, N. R.; BRUGOS, R.; KADIYALA, V.; CARRION, A. R.; BANGEPPAGARI, M. Removal of petroleum hydrocarbons from crude oil in solid and slurry phase by mixed soil microorganisms isolated from ecuadorion oil fields. International Biodeterioration \& Biodegradation, v. 108, p. 85-90, 2016. https://doi.org/10.1016/j.ibiod.2015.12.015

Rev. Ambient. Água vol. 14 n. 4, e2360 - Taubaté 2019 
MORAES, S. S. M.; SANTOS, E. M. Avaliação de impactos ambientais (AIA): instrumento importante na sustentabilidade dos projetos rodoviários. Revista da Farn, v. 3, n. 1-2, p. 45-58, 2004.

OLIVEIRA, J. P. W.; SANTOS, R. N.; BOEIRA, J. M. Genotoxicidade e análises físicoquímicas das águas do Rio Sinos (RS) usando Allium cepa e Eichhornia crassipes como bioindicadores. Biochemistry and Biotechnology Reports, v. 1, n. 1, p. 15-22, 2012. http://dx.doi.org/10.5433/2316-5200.2012v1n1p15

RADIC, S.; STIPANICEV, D.; VUJCIC, V.; RAJCIC, M.; SIRAC, S.; PEVALEK-KOZLINA, B. The evaluation of surface and wastewater genotoxicity using the Allium cepa Test. Science of the Total Environmental, v. 408, p. 1228-1233, 2010. https://doi.org/10.1016/j.scitotenv.2009.11.055

RAHMAN, I. M. M.; ISLAM, M. M.; HOSSAIN, M. M.; HOSSAIN, M. S.; BEGUM, Z. A.; CHOWDHURY, D. A.; CHAKRABORTY, M. K.; RAHMAN, M. A.; NAZIMUDDIN, M.; HASEGAWA, H. Stagnant surface water bodies (SSWBs) as an alternative water resource for the Chittagong metropolitan area of Bangladesh: physicochemical characterization in terms of water quality indices. Environmental Monitoring and Assessment, v. 173, p. 669-https://doi.org/10.1007/s10661-010-1414-7 684, 2011

SEKABIRA, K.; ORIGA, H. O.; BASAMBA, T. A.; MUTUMBA, G.; KAKUDIDI, E. Heavy metal assessment and water quality values in urban stream and rain water. International Journal of Environmental Science and Technology, v. 7, p. 759-770, 2010. https://doi.org/10.1007/BF03326185

SILVA, J.; HEUSER, V.; ANDRADE, V. Biomonitoramento ambiental. In: SILVA, J.; ERDTMANN, B.; HENRIQUES, J. A. P. (Eds.). Genética Toxicológica. Porto Alegre: Alcance, 2003 p. 166-180.

SILVA, L.; HELDWEIN, C.; REETZ, L.; HORNER, R.; MALLMANN, C.; HEINZMANN, B. Composição química, atividade antibacteriana in vitro e toxicidade em artemia salina do óleo essencial das inflorescências de Ocimum gratissimum L., lamiaceae. Revista Brasileira de Farmacognosia, v. 20, n. 5, p. 700-705, 2010. https://dx.doi.org/10.1590/S0102-695X2010005000010

SPOSITO, J. C. V.; FRANCISCO, L. F. V.; CRISPIM, B. A.; DANTAS, F. G. S.; SOUZA, J. P.; VIANA, L. F.; SOLÓRZANO, J. C. J.; OLIVEIRA, K. M. P.; BARUFATTI, A. Influence of Land Use and Cover on Toxicogenetic Potential of Surface Water from Central West Brazilian Rivers. Archives of Environmental Contamination and Toxicology, v. 76, p. 483-495, 2019. https://doi.org/10.1007/s00244-019-00603-2

TAVARES, R. D. Avaliação físico-química e ecotoxicológica de efluentes provenientes de estações de tratamento de esgoto. Revista Ibero-Americana de Ciências Ambientais, v. 5, n. 1, p. 303-318, 2014. https://doi.org/10.6008/SPC2179-6858.2014.001.0022

VAN BOHEMEN, H. D.; JANSSEN VAN DE LAAK, W. H. The Influence of Road Infrastructure and Traffic on Soil, Water, and Air Quality. Environmental Management, v. 31, p. 50-68, 2003. https://doi.org/10.1007/s00267-002-2802-8

VAZ, C.; OLIVEIRA, T. M. N. O.; BÖHM, R. F. S.; SPITZNER, E. C.; SIMM, M.; BARROS, V. G. Use of Artemia salina to identify sites with the risk of contamination in the waters of Babitonga Bay. Toxicology Letters, v. 196, p. 37-351, 2010. http://dx.doi.org/10.1016\%2Fj.toxlet.2010.03.423 
VON SPERLING, M. Princípios de tratamento biológico de águas residuárias: introdução à qualidade das águas e ao tratamento de esgotos. Belo Horizonte, 2005.

YALCUK, A.; POSTALCIOGLU, S. Evaluation of pool water quality of trout farms by fuzzy logic: monitoring of pool water quality for trout farms. International Journal of Environmental Science and Technology, v. 12, p. 1503-1514, 2015. https://doi.org/10.1007/s13762-014-0536-9 


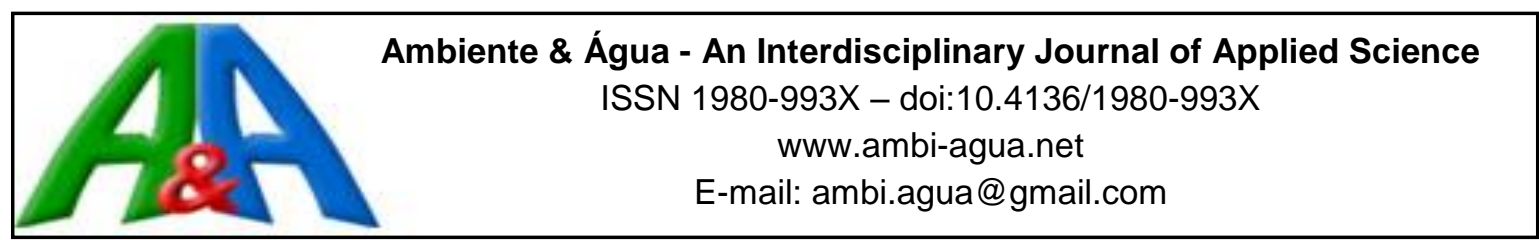

\title{
Autochthonous microalgae cultivation with anaerobic effluent: isolation of strains, survivorship, and characterization of the produced biomass
}

\author{
ARTICLES doi:10.4136/ambi-agua.2362
}

Received: 19 Dec. 2018; Accepted: 26 May 2019

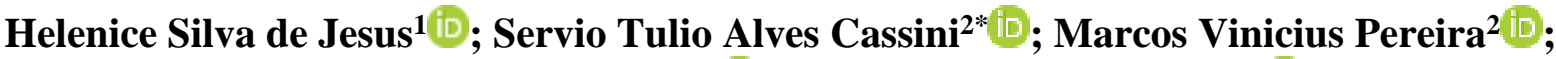 \\ Aline Figueredo Dassoler ${ }^{2}$; Ricardo Franci Gonçalves ${ }^{2}$ iD \\ ${ }^{1}$ Instituto Federal de Educação, Ciência e Tecnologia da Bahia (IFBA), Salvador, BA, Brasil \\ Departamento de Química. E-mail: helenicest@yahoo.com.br \\ ${ }^{2}$ Universidade Federal do Espírito Santo (UFES), Vitória, ES, Brasil \\ Departamento Engenharia Ambiental. E-mail: casinist@gmail.com, \\ marcos.lavagnoli@hotmail.com, aline.dassoler@hotmail.com,rfg822@gmail.com \\ *Corresponding author
}

\begin{abstract}
Six Chlorophyta strains were isolated from the effluent of an anaerobic reactor treating municipal wastewater and identified as Desmodesmus sp. L02, Chlorococcum sp. L04, Coccomyxa sp. L05, Chlorella sp. L06, Scenedesmus sp. L08 and Tetradesmus sp. L09. The microalgae strains were cultivated in unsterilized wastewater under laboratory conditions to determine their potential to survive under non-sterile conditions. The strains were also cultivated in sterilized wastewater in order to analyze their nutrient removal potential and characterize the produced biomass. Amongst the isolated microalgae, Chlorella sp. L06 had the highest survivorship percentage (90\%) for ten days of culture, whilst Desmodesmus sp. L02 had the lowest, not exceeding $1.8 \%$ after $24 \mathrm{~h}$ of inoculation. The dried biomass of the isolates showed an average of $28.7 \%$ of protein, $15.4 \%$ of lipids and $14.8 \%$ of carbohydrates, with Chlorococcum sp. L04 reaching $29.3 \%$ of carbohydrates. In terms of nutrients, nitrogen removal varied from 59.2 to $93 \%$, and phosphorus removal ranged from 79.1 to $95.4 \%$, with Tetradesmus sp. L09 being the most efficient strain.
\end{abstract}

Keywords: anaerobic effluent, microalgae, survivorship.

\section{Cultivo de microalgas nativas com efluente anaeróbio: isolamento de cepas, sobrevivência e caracterização da biomassa algácea}

\section{RESUMO}

Seis cepas de Chlorophyta foram isoladas do efluente de um reator anaeróbio tratando esgoto sanitário e identificadas como Desmodesmus sp. L02, Chlorococcum sp. L04, Coccomyxa sp. L05, Chlorella sp. L06, Scenedesmus sp. L08 e Tetradesmus sp. L09. As cepas de microalgas foram cultivadas em efluente não-esterilizado em condições de laboratório para determinar os potenciais de sobrevivência sob condições não estéreis. As cepas também foram cultivadas em efluente esterilizado para avaliar os potenciais de remoção de nutrientes e caracterizar bioquimicamente a biomassa produzida. Entre as microalgas isoladas, Chlorella 
sp. L06 teve a maior porcentagem de sobrevivência (90\%) por dez dias de cultura, enquanto Desmodesmus sp. L02 apresentou o menor valor, não excedendo 1,8\% após $24 \mathrm{~h}$ de inoculação. A biomassa seca dos isolados apresentou uma média de 28,7\% de proteína, 15,4\% de lipídios e 14,8\% de carboidratos, com Chlorococcum sp. L04 atingindo 29,3\% de carboidratos. Em termos de nutrientes, a remoção de nitrogênio variou de 59,2 a 93\%, e a remoção de fósforo variou de 79,1 a 95,4\%, com Tetradesmus sp. L09 sendo a cepa mais eficiente.

Palavras-chave: efluente anaeróbio, microalgas, sobrevivência.

\section{INTRODUCTION}

Since their inception, wastewater treatment plants (WWTPs) have had a fundamental role in minimizing the impact on water environments on a global level. Until recent years, WWTPs have been implemented with the single objective of protecting the health of humans and the environment. Nevertheless, a paradigm change is occurring in the universe of wastewater treatment, changing the emphasis on the treatment to the focus on recovering the various resources within the wastewater, such as water and nutrients (Puyol et al., 2017). Microalgaebased technologies are perfect candidates to fulfil the aforementioned objectives, considering that these microorganisms grow rapidly, can be cultivated on non-arable lands using wastewaters, promote $\mathrm{CO}_{2}$ sequestration and can be used to polish several types of effluents.

However, the cultivation of microalgae in wastewater effluents is not a new subject, considering that Oswald and Gotaas (1957) first proposed it in the 1950s, and in the decades since, high-rate algal ponds (HRAPs) have been widely studied - only with the purpose of treating wastewater. The algal biomass produced in these systems has not been traditionally recovered to use as feedstock for bioenergy production, specifically due unsatisfactory productivities and the fact that there are no low-cost and effective harvesting technologies.

Conventionally, microalgae biomass production systems use chemical fertilizers and clean water from the distribution grid, and consequently the high costs for the cultivation are one of the main bottlenecks of microalgae-to-biofuel systems in real scale (Brasil et al., 2017). For this reason, most of the scientific community assumes that to reduce the environmental impacts and improve the economic viability of microalgae-to-biofuel processes, alternative sources of water and nutrients must be used. In fact, numerous authors have already reached high biomass productivities when cultivating microalgae in wastewaters, as evidenced by a recent review on the subject ( $\mathrm{Lv}$ et al., 2017).

Cho et al. (2017) discuss that microalgae that are indigenous to the type of wastewater used as medium could display higher adaptability to grow and remove nutrients from it. However, most studies focus on strains from Microalgae Culture Collections, ignoring the microalgal diversity that is already present in the wastewater. Therefore, this study had the primary objective of isolating microalgae strains from the effluent of a UASB reactor treating municipal sewage, in order to cultivate them in non-sterile wastewater and analyze their survivorship potential. The strains were also cultivated in sterilized wastewater in order to determine their growth, nutrient removal potential and to analyze the biochemical properties of the produced biomass.

\section{MATERIALS AND METHODS}

\subsection{Microalgae isolation and identification}

To isolate each strain, borosilicate flasks were filled with the unfiltered effluent from an upflow anaerobic sludge blanket reactor (UASB) treating municipal wastewater, located at an experimental WWTP in the Federal University of Espírito Santo (UFES), closed with cotton 
leads and exposed to indirect sunlight for 15 days to stimulate the growth of autochthonous microalgae and other microorganisms. After this period, the raw effluent turned green due to the multiplication of naturally present microalgae cells, which were favored by the environmental change from complete darkness (inside the reactor) to indirect sunlight. Samples from these mixed cultures were used for the isolation procedures, namely the micropipette method followed by the streak plating technique until unialgal colonies were obtained, according to Andersen and Kawachi (2005). The streak plates were incubated with the following conditions: temperature of $27 \pm 3^{\circ} \mathrm{C}$; luminosity of $80 \mu \mathrm{mol} \mathrm{m} \mathrm{m}^{-2} \mathrm{~s}^{-1}$; and $12 \mathrm{~h} / 12 \mathrm{~h}$ (light/dark) photoperiod. Isolated colonies were kept in liquid sterile effluent media and on agar effluent plates and incubated with the same conditions as the streak plates. Further information on the isolation, identification and maintenance procedures applied herein can be found in Pereira et al. (2018).

\subsection{Effluent sampling and analysis}

The effluent was sampled, filtered with glass fiber membrane filters $(\mathrm{GF} / \mathrm{C} ; 1.2 \mu \mathrm{m}$ pore size) and analyzed for $\mathrm{pH}$, volatile solids, chemical oxygen demand (COD), total Kjeldahl nitrogen (TKN) and total phosphorus (TP), according to the Standard Methods for the Examination of Water and Wastewater (APHA et al., 2005).

The main characteristics of the unsterilized filtered effluents (UFE) throughout the experiments $(\mathrm{n}=3)$ were: $28.8 \pm 1.5 \mathrm{mg} \mathrm{L}^{-1}$ for $\mathrm{TKN} ; 5.0 \pm 0.7 \mathrm{mg} \mathrm{L}^{-1}$ for TP; $208 \pm 16 \mathrm{mg} \mathrm{O}_{2} \mathrm{~L}^{-1}$ for COD; and $\mathrm{pH}$ of 7.6. On the other hand, the autoclaved filtered effluents (AFE) had: $23.5 \pm 1.4 \mathrm{mg} \mathrm{L}^{-1}$ of TKN; $5.6 \pm 0.6 \mathrm{mg} \mathrm{L}^{-1}$ of TP; $162 \pm 10 \mathrm{mg} \mathrm{O}_{2} \mathrm{~L}^{-1}$ of COD and $\mathrm{pH}$ of 10 .

\subsection{Survivorship of the isolated strains in unsterilized filtered effluent (UFE)}

To verify the survivorship potential of the isolated strains, Erlenmeyer flasks $(50 \mathrm{~mL})$ were filled with $30 \mathrm{~mL}$ of UFE and $1 \mathrm{~mL}$ of each inoculum $(\mathrm{n}=6)$, closed with sterile cotton leads, then incubated with a temperature of $27 \pm 3^{\circ} \mathrm{C}$; luminosity of $80 \mu \mathrm{mol} \mathrm{m} \mathrm{m}^{-2} \mathrm{~s}^{-1}$; and $12 \mathrm{~h} / 12 \mathrm{~h}$ (light/dark) photoperiod over 10 days. Fresh samples were taken daily to determine the cell density (N) with an Improved Neubauer Chamber and a microscope (Carl ZEISS Axioplan-2), using standard counting procedures $(n=3)$. The survivorship potential was determined according to the following Equation 1:

$\%$ Survivorship $=\frac{N \text { of the isolate }}{N \text { of all microalgae }} X 100$

Where the cell density $(\mathrm{N})$ of a determined isolate was divided by the cell density of all the microalgae cells present in the counting fields and multiplied by 100 .

\subsection{Cultivation of the strains, characterization of the biomass and nutrient removal}

Each isolated strain was cultivated in borosilicate glass flasks (22 L capacity) with $20 \mathrm{~L}$ of autoclaved filtered effluent (AFE) and its respective inoculum under the following conditions: temperature of $27 \pm 3^{\circ} \mathrm{C}$; luminosity of $80 \mu \mathrm{mol} \mathrm{m} \mathrm{m}^{-2} \mathrm{~s}^{-1} ; 12 \mathrm{~h} / 12 \mathrm{~h}$ (light/dark) photoperiod and continuous air bubbling $\left(1.5 \mathrm{~mL} \mathrm{~s}^{-1}\right)$. The cultures were monitored daily with an in vivo fluorometer during 14 days in order to establish the growth curves. In vivo chlorophyll $a$ measurements were previously correlated with results from the acetone extraction method 10200-H (APHA et al., 2005) for each microalgae strain. The extraction method was performed with $10 \mathrm{~mL}(\mathrm{n}=3)$ samples and the readings were carried out with a spectrophotometer DR/2000 (HACH).

On the $14^{\text {th }}$ day the biomass was harvested with $250 \mathrm{mg} \mathrm{L}^{-1}$ of $\mathrm{Al}_{2}\left(\mathrm{SO}_{4}\right)_{3}$, centrifuged, dried $\left(60^{\circ} \mathrm{C}\right)$ and pulverized with a pestle and mortar. The liquid phase was filtered with glass 
fiber membrane filters (GF/C; $1.2 \mu \mathrm{m}$ pore size) and analyzed for all the parameters within Section 2.2. in order to determine the nutrient and COD removal potential of each strain. The dried biomass was used for the biochemical characterization of lipids, proteins and carbohydrates as in Pereira et al. (2018).

\section{RESULTS AND DISCUSSION}

\subsection{Microalgae isolation and identification}

Microscopic examination of the algal bloom (obtained by incubating natural UASB effluent) showed the presence of several types of green microalgae, diatoms and cyanobacteria, as well as fungi and protozoans. Six Chlorophyta strains were isolated as described in Section 2.1 and identified based on their morphology as Desmodesmus sp. L02, Chlorococcum sp. L04, Coccomyxa sp. L05, Chlorella sp. L06, Scenedesmus sp. L08 and Tetradesmus sp. L09. These six strains were maintained in laboratory according to Lorenz et al. (2005) and were used as inocula for both the survivorship and cultivation experiments.

\subsection{Survivorship of the isolated strains in unsterilized filtered effluent (UFE)}

After the daily cell density monitoring of the cultures, survivorship curves were made for each strain, and the results are depicted in Figure 1.

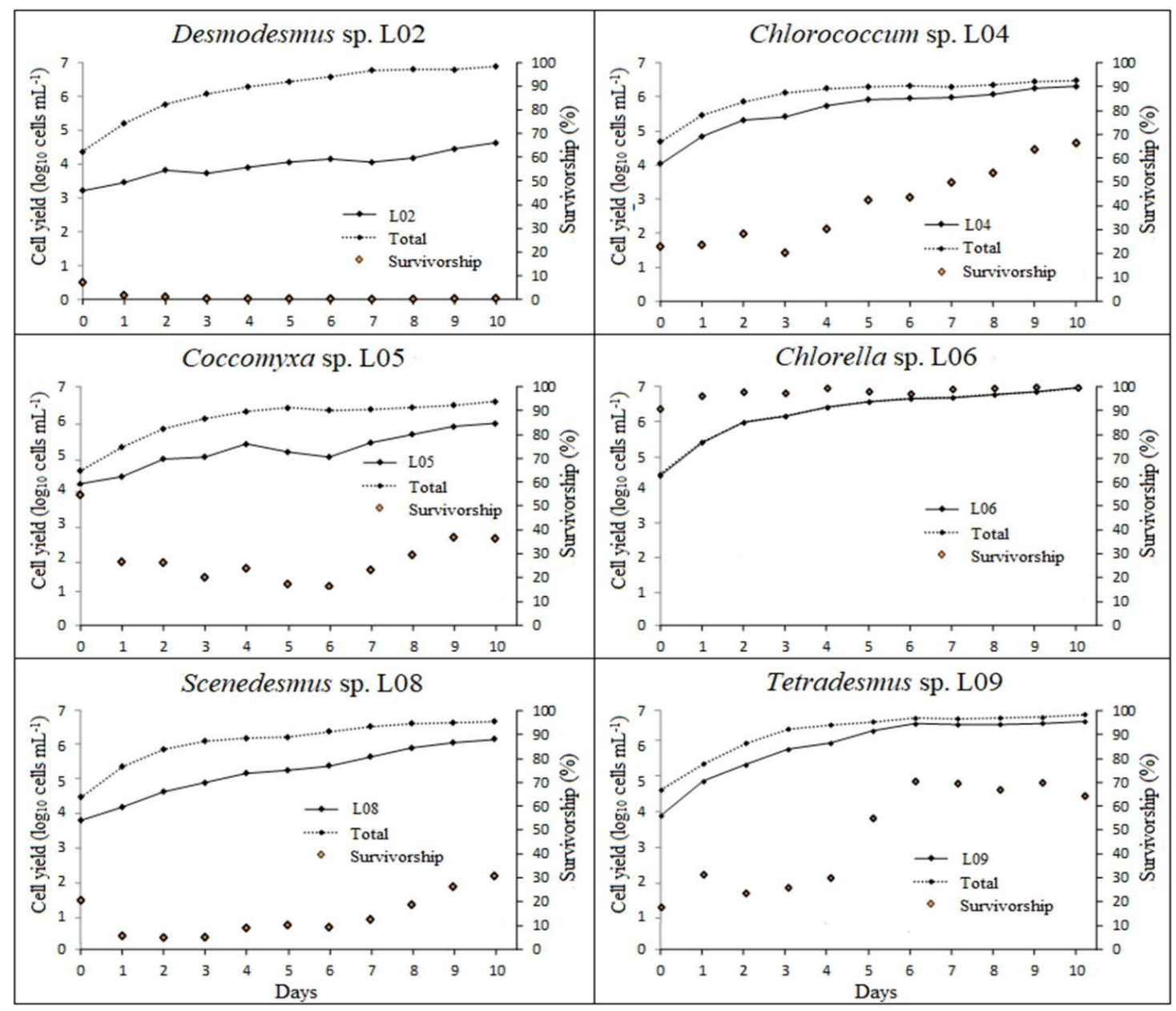

Figure 1. Growth and survivorship curve of six microalgae strains cultured in unsterilized filtered effluent (UFE) in laboratory at a temperature of $27 \pm 3^{\circ} \mathrm{C}$, luminosity of $80 \mu \mathrm{mol} \mathrm{m} \mathrm{m}^{-2} \mathrm{~s}^{-1}$ and $12 \mathrm{~h} / 12 \mathrm{~h}$ (light/dark) photoperiod over 10 days. Dashed lines represent the total cell density, including all microalgae, continuous lines represents the isolate's cell density and the orange diamonds represent the survivorship of the isolate at a given time. 
Results showed that Chlorella sp. L06 was the most adaptable strain, being able to develop and grow in non-sterile wastewater despite the presence of competitors and predators. During the ten days of experiment, this strain had a survivorship of higher than $90 \%$ for each day, with an average of $97.7 \%$. As for the other strains, the mean survivorship value was $1.2 \%$ for Desmodesmus sp. L02, $40.3 \%$ for Chlorococcum sp. L04, $16.3 \%$ for Coccomyxa sp. L05, $14.9 \%$ for Scenedesmus sp. L08 and $47.5 \%$ for Tetradesmus sp. L09.

Although all the strains were isolated from the same wastewater as the one used to cultivate them, it is natural to assume that different strains have different capacities to thrive in a determined environment. Some of them can be weaker competitors, or more susceptible to environmental changes. This seemed to be the case for Desmodesmus sp. L02, due to its inability to develop properly in the UFE medium. On the other hand, Chlorella sp. L06 had the best survivorship results, which was expected, considering that species from the genus Chlorella have been widely used in studies on cultivation of microalgae biomass linked to wastewater treatment (Lv et al., 2017). A study conducted by Mennaa et al. (2015) compared the growth of several microalgae species on non-sterile urban wastewater and obtained better growth results for the Chlorella species, when compared with Scenedesmus species.

Cho et al. (2011) state that the effluents from WWTPs can be used to produce microalgae biomass at a much lower cost, since it does not require nutrient addition, only a pretreatment method such as filtration or UV disinfection for the control of competing microorganisms. The capacity to grow in non-sterile wastewater is a trait that many researchers consider crucial for a microalgae strain, considering the cost reduction in the pretreatment of the wastewater used as media (Guldhe et al., 2017).

\subsection{Growth of the isolated strains in autoclaved filtered effluent (AFE)}

The microalgae strains were cultivated in $22 \mathrm{~L}$ flasks according to Section 2.4. and the growth results, based on chlorophyll $a$, are depicted in Figure 2.

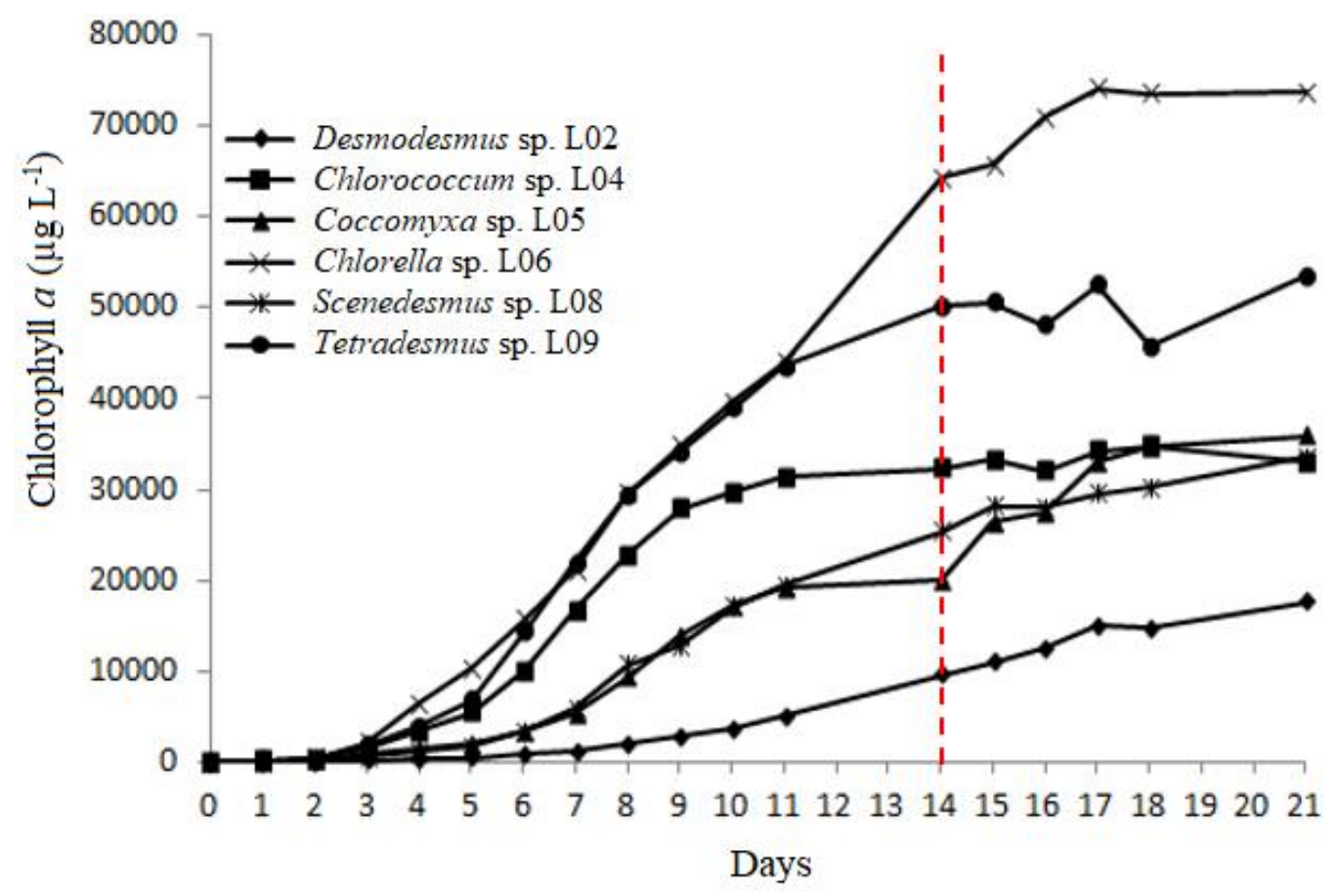

Figure 2. Growth curve, based on chlorophyll $a$, of six microalgae strains cultured in autoclaved filtered effluent (AFE) in laboratory at a temperature of $27 \pm 3^{\circ} \mathrm{C}$, luminosity of $80 \mu \mathrm{mol} \mathrm{m} \mathrm{m}^{-2} \mathrm{~s}^{-1}, 12 \mathrm{~h} / 12 \mathrm{~h}$ (light/dark) photoperiod and air bubbling $\left(1.5 \mathrm{~mL} \mathrm{~s}^{-1}\right)$ over 21 days. The dashed red line represents the day that biomass was harvested from a large sample of the cultures. 
The growth results showed that all the isolated strains were capable of growing in AFE and reaching an exponential growth phase, indicating that this type of medium could support microalgae cultivation, despite the fact that its initial $\mathrm{pH}$ was 10 . Microscopic examination showed that each microalgae culture was clearly dominated by the strain of its respective inoculum. Regarding each strain, Chlorella sp. L06 was not only the most adaptable one in UFE, it was also the strain with the best results on AFE with air bubbling. Following the same trend, Desmodesmus sp. L02 had the least satisfactory growth results, and Tetradesmus sp. L09 was the second best.

\subsection{Biochemical characterization of the produced biomass}

The dried biomass of each microalgae strain was characterized in terms of biochemical composition and the results are shown in Figure 3.

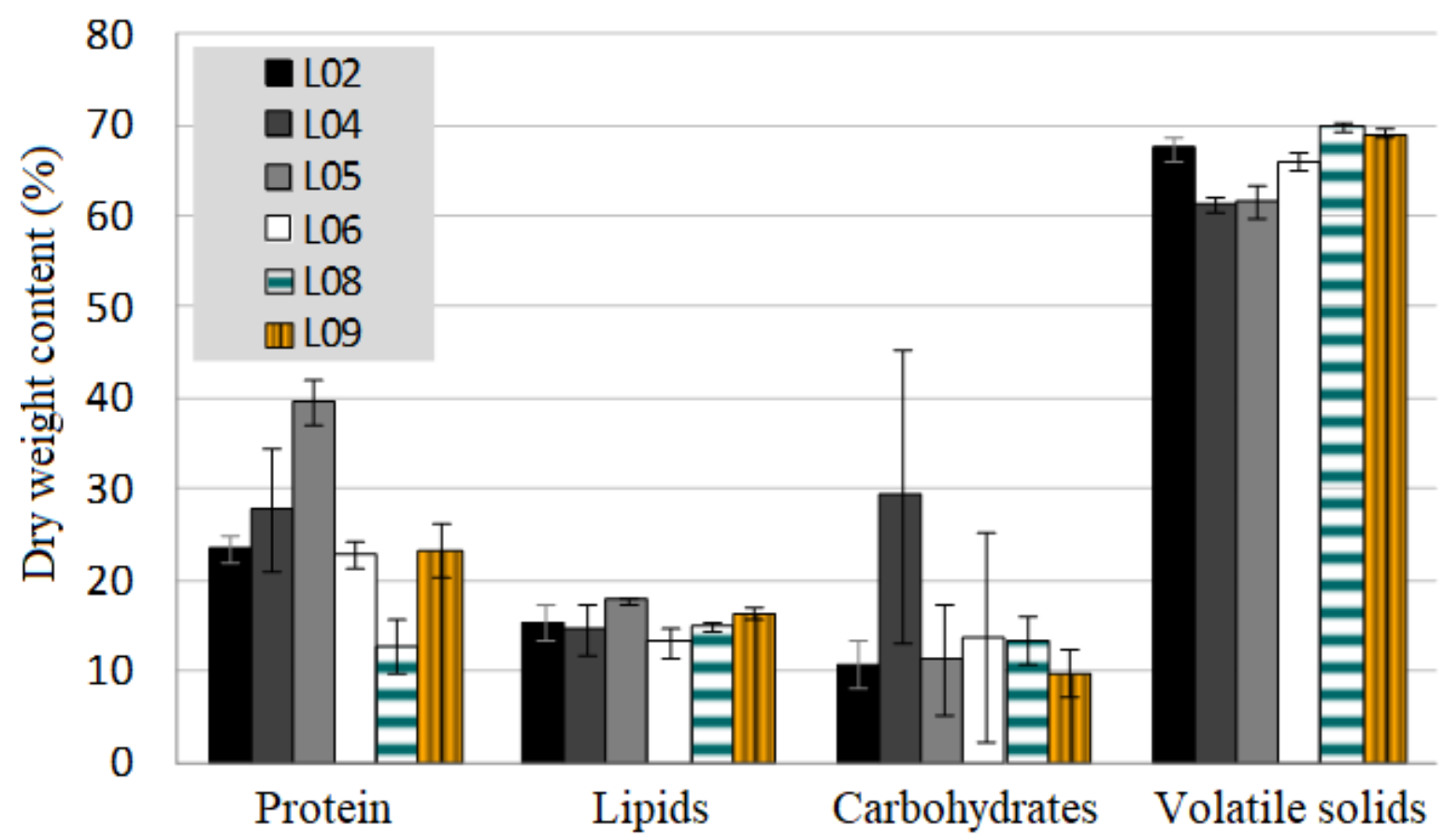

Figure 3. Biochemical composition of the dried biomass for each strain cultivated in autoclaved filtered effluent (AFE) in laboratory at a temperature of $27 \pm 3^{\circ} \mathrm{C}$, luminosity of $80 \mu \mathrm{mol} \mathrm{m}^{-2} \mathrm{~s}^{-1}, 12$ $\mathrm{h} / 12 \mathrm{~h}$ (light/dark) photoperiod and air bubbling $\left(1.5 \mathrm{~mL} \mathrm{~s}^{-1}\right)$ over 14 days (bars represent $\mathrm{SD}$ and $\mathrm{n}=3)$.

The average composition of the biomass was $25.0 \%$ protein, $15.4 \%$ lipids and $14.8 \%$ carbohydrates, all within $66.0 \%$ of volatile solids. It can be observed that the protein content was higher than the other fractions in every case (except for Scenedesmus sp. L08), followed by lipids and carbohydrates. Coccomyxa sp. L05 had the highest protein content amongst the strains (39.7\%) and Scenedesmus sp. L08 had the lowest (12.9\%). Regarding biomass-tobioenergy processes, the anaerobic digestion of the biomass is an attractive alternative to generate biogas within WWTPs that already use anaerobic systems. However, high protein content on the biomass (low $\mathrm{C}: \mathrm{N}$ ratios) is often unfavorable for anaerobic digestion, considering the inhibitory effects that $\mathrm{NH}_{3}$ has over the methanoarchea community (Fricke et al., 2007).

Mutanda et al. (2011) discuss that the co-digestion of the biomass with carbon-rich substrates and the pre-treatment of the biomass are both alternative strategies that can significantly enhance bio-conversion into methane. In fact, Passos et al. (2015) achieved higher methane production when the microalgae biomass was pre-treated with physical methods

Rev. Ambient. Água vol. 14 n. 4, e2362 - Taubaté 2019 
(thermal, microwave and ultrasound). Other than the production of biogas through anaerobic digestion, the biomass can also be used in the production of ethanol through the fermentation of the carbohydrates. In this case, Chlorococcum sp. L04 deserves recognition due to the high carbohydrate content $(29.3 \%)$.

\subsection{Nutrient and COD removal efficiency}

Table 1 shows the nutrient and COD removal efficiency from the liquid phase based on different microalgae cultures after the addition of the coagulant.

Table 1. Nutrients and COD concentration in the liquid phase of the microalgae cultures at the beginning of the experiment (in) and after the addition of the coagulant agent (out). The strains were cultivated in autoclaved filtered effluent (AFE) in laboratory at a temperature of $27 \pm 3^{\circ} \mathrm{C}$, luminosity of $80 \mu \mathrm{mol} \mathrm{m}{ }^{-2} \mathrm{~s}^{-1}, 12 \mathrm{~h} / 12 \mathrm{~h}$ (light/dark) photoperiod and air bubbling $\left(1.5 \mathrm{~mL} \mathrm{~s}^{-1}\right)$ over 14 days $( \pm \mathrm{SD}$ and $\mathrm{n}=3$ ).

\begin{tabular}{lccccccc}
\hline & \multicolumn{7}{c}{ Cultures/Strains } \\
\hline Parameters & Units & L02 & L04 & L05 & L06 & L08 & L09 \\
\hline TKN (in) & $\mathrm{mg} \mathrm{L}^{-1}$ & $26.5 \pm 0.3$ & $26.5 \pm 0.3$ & $26.5 \pm 0.3$ & $26.5 \pm 0.3$ & $26.5 \pm 0.3$ & $26.5 \pm 0.3$ \\
TKN (out) & $\mathrm{mg} \mathrm{L}^{-1}$ & $10.8 \pm 0.3$ & $5.6 \pm 1.0$ & $3.9 \pm 1.8$ & $8.9 \pm 0.8$ & $8.7 \pm 0.3$ & $1.8 \pm 1.3$ \\
TKN removal & $\%$ & 59.2 & 78.9 & 85.3 & 66.4 & 67.2 & 93.2 \\
TP (in) & $\mathrm{mg} \mathrm{L}^{-1}$ & $7.1 \pm 0.2$ & $7.1 \pm 0.2$ & $7.1 \pm 0.2$ & $7.1 \pm 0.2$ & $7.1 \pm 0.2$ & $7.1 \pm 0.2$ \\
TP (out) & $\mathrm{mg} \mathrm{L}^{-1}$ & $1.5 \pm 0.0$ & $0.7 \pm 0.0$ & $0.8 \pm 0.0$ & $0.7 \pm 0.1$ & $0.8 \pm 0.2$ & $0.3 \pm 0.0$ \\
TP removal & $\%$ & 78.9 & 90.1 & 88.7 & 90.1 & 88.7 & 95.8 \\
COD (in) & $\mathrm{mg} \mathrm{L}^{-1}$ & $184 \pm 6$ & $184 \pm 6$ & $184 \pm 6$ & $184 \pm 6$ & $184 \pm 6$ & $184 \pm 6$ \\
COD (out) & $\mathrm{mg} \mathrm{L}^{-1}$ & $93 \pm 0.0$ & $101 \pm 4.0$ & $82 \pm 8.0$ & $64 \pm 5.0$ & $76 \pm 11.0$ & $58 \pm 13.0$ \\
COD removal & $\%$ & 49.4 & 45.3 & 55.3 & 64.9 & 58.7 & 68.3 \\
\hline Abbration
\end{tabular}

Abbreviations: TKN, total Kjeldahl nitrogen; TP, total phosphorus; COD, chemical oxygen demand.

It can be observed that, at the end of the experiment, the TKN removal varied from 59.2\% (Desmodesmus sp. L02) to 93.2\% (Tetradesmus sp. L09). Regarding TP, removal efficiency was higher than $80 \%$ for all cultures (except Desmodesmus sp. L02), with Tetradesmus sp. L09 reaching $95.8 \%$. In terms of $\mathrm{COD}$, it is interesting to note that its concentration was already low at the beginning of the experiment $\left(184 \mathrm{mg} \mathrm{L}^{-1}\right)$, as expected, since secondary treated effluents from anaerobic treatments are generally low in COD and BOD. However, the removal efficiency of this organic fraction still ranged from $45.3 \%$ (Chlorococcum sp. L04) to higher than $68.3 \%$ (Tetradesmus sp. L09). COD removal in this case may have been caused by the high photosynthetic $\mathrm{O}_{2}$ generation inside the flasks, which could enhance the oxidation of organic matter by heterotrophic microorganisms. On the other hand, high COD removal can indicate microalgal mixotrophic nutrition, as discussed by Park et al. (2011). Adsorption by the biomass and or filter membrane may have also contributed to the COD removal, since a fraction of the COD is often recalcitrant, therefore difficult to assimilate biologically.

The results for removal efficiency obtained herein are similar to the ones obtained by Mennaa et al. (2015), and agree with the range of values reported in a recent review study on the subject of microalgae cultivation in secondary-treated wastewaters (Lv et al., 2017). On the other hand, since the $\mathrm{pH}$ of all cultures reached values above 9.0, it might be reasonable to assume that at least part of the nitrogen was lost due to abiotic processes such as ammonia stripping, rather than assimilation by microorganisms (Nurdogan and Oswald, 1995). The same logic can be applied to phosphorus removal due to the chemical precipitation of this nutrient at $\mathrm{pH}$ levels higher than 9.0. Nonetheless, in terms of tertiary treatment, we can conclude that nitrogen, phosphorus and COD were efficiently removed from the liquid phase of the effluent in this experiment. 


\section{CONCLUSIONS}

The results showed that Chlorella sp. L06 and Tetradesmus sp. L09 were able to survive and thrive in unsterilized UASB effluent after inoculation, indicating that they were more adapted to this medium than the other microalgae isolates, in terms of competition for nutrients and resiliency to protozoan grazers. The strains were also cultivated in autoclaved UASB effluent, and all of them were able to grow and reach the exponential growth phase.

The dry biomass of the isolates showed, on average, $66.0 \%$ of volatile solids, of which $25.0 \%$ was composed of proteins, $15.4 \%$ of total lipids and $14.8 \%$ of total carbohydrates. The microalgae cultures were able to remove up to $93 \%$ of nitrogen and $95.4 \%$ of phosphorus from the wastewater's liquid phase, improving the UASB effluent quality and converting these nutrients into biomass that can be used as feedstock for the production of biogas or syngas.

\section{ACKNOWLEDGEMENTS}

The authors would like to express sincere gratitude to the Brazilian fostering agencies FAPES (Fundação de Amparo à Pesquisa e Inovação do Espírito Santo) for financial support and CAPES (Coordenação de Aperfeiçoamento de Pessoal de Nível Superior) for the doctoral scholarship to the first author (Grant 01.13.0092-00).

\section{REFERENCES}

ANDERSEN R. A.; KAWACHI, M. Traditional microalgae isolation techniques. In: ANDERSEN, R. A. (Ed.) Algal culturing techniques. London: Elsevier, 2005. p.83100.

APHA; AWWA; WEF. Standard Methods for the Examination of Water and Wastewater. 21. ed. Washington, 2005.

BRASIL, B. S.; SILVA, F. C.; SIQUEIRA, F. Microalgae biorefineries: the Brazilian scenario in perspective. New Biotechnology, v. 39, n. 1, p. 90-98, 2017. https://doi.org/10.1016/j.nbt.2016.04.007

CHO, S.; LUONG, T. T.; LEE, D.; OH, Y-K.; LEE, T. Reuse of effluent water from municipal wastewater treatment plant in microalgae cultivation for biofuel production. Bioresource $\begin{array}{lllllll}\text { Technology, } & \text { v. } \quad 102, \quad \text { n. } & 1, \quad \text { p. } & 8639-8645, & \end{array}$ https://doi.org/10.1016/j.biortech.2011.03.037

CHO, D.; CHOI, J.; KANG, Z.; KIM, B. H.; OH, H. M.; KIM, H. S.; RAMANAN, R. Microalgal diversity fosters stable biomass productivity in open ponds treating wastewater. Scientific Reports, v. 7, n. 1, 2017. https://dx.doi.org/10.1038/s41598-01702139-8

FRICKE, K.; SANTEN, H.; WALLMANN, R. Operating problems in anaerobic digestion plants resulting from nitrogen in MSW. Waste Management, v. 27, n. 1, p. 30-43, 2007. https://doi.org/10.1016/j.wasman.2006.03.003

GULDHE, A.; KUMARI, S.; RAMANNA, L.; RAMSUNDAR, P.; SINGH, P.; RAWAT, I.; BUX, F. Prospects, recent advancements and challenges of different wastewater streams for microalgal cultivation. Journal of Environmental Management, v. 203, n. 1, p. 299315, 2017. https://doi.org/10.1016/j.jenvman.2017.08.012 
LORENZ, M.; FRIEDL, T.; DAY, J. G. Perpetual maintenance of actively metabolizing microalgal cultures. In: ANDERSEN, R. A. (Ed.). Algal culturing techniques. London: Elsevier, 2005. p.145-156.

LV, J.; FENG, J.; LIU, Q.; XIE, S. Microalgal cultivation in secondary effluent: recent developments and future work. International Journal of Molecular Sciences, v. 18, n. 1, p. 1-18, 2017. https://doi.org/10.3390/ijms18010079

MENNAA, F. Z.; ARBIB, Z.; PERALES, J. A. Urban wastewater treatment by seven species of microalgae and an algal bloom: biomass production, $\mathrm{N}$ and $\mathrm{P}$ removal kinetics and

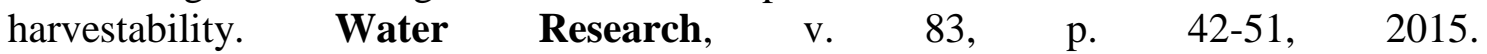
https://doi.org/10.1016/j.watres.2015.06.007

MUTANDA, T.; RAMESH, D.; KARTHIKEYAN, S.; KUMARI, S.; ANANDRAJ, A.; BUX, F. Bioprospecting for hyper-lipid producing microalgal strains for sustainable biofuel production. Bioresource Technology, v. 102, p. 57-70, 2011. https://doi.org/10.1016/j.biortech.2010.06.077

NURDOGAN, Y.; OSWALD, W. J. Enhanced nutrient removal in high-rate ponds. Water Science and Technology, v. 12, p. 33-43, 1995. https://doi.org/10.1016/02731223(95)00490-E

OSWALD, W. J.; GOTAAS, H. B. Photosynthesis in sewage treatment. Transactions of the American Society of Civil Engineers, v. 122, p. 73-105, 1957.

PARK, J. B. K.; CRAGGS, R. J.; SHILTON, A. N. Wastewater treatment high rate algal ponds for biofuel production. Bioresource Technology, v. 102, n. 35, p. 35-42, 2011. https://doi.org/10.1016/j.biortech.2010.06.158

PASSOS, F.; CARRETERO, J.; FERRER, I. Comparing pretreatment methods for improving microalgae anaerobic digestion: Thermal, hydrothermal, microwave and ultrasound. $\begin{array}{lllllll}\text { Chemical Engineering Journal, } & \text { v. 279, p. 667-672, } 2015 .\end{array}$ https://doi.org/10.1016/j.cej.2015.05.065

PEREIRA, M. V.; DASSOLER, A. F.; ANTUNES, P. W.; GONÇALVES, R. F.; CASSINI, S. $\mathrm{T}$. Indigenous microalgae biomass cultivation in continuous reactor with anaerobic effluent: effect of dilution rate on productivity, nutrient removal and bioindicators. $\begin{array}{llll}\text { Environmental Technology, } & \text { p. } & 1-13, & \end{array}$ https://dx.doi.org/10.1080/09593330.2018.1549105

PUYOL, D.; BATSTONE, D. J.; HÜLSEN, T.; ASTALS, S.; PECES, M.; KROMER, J. O. Resource recovery from wastewater by biological technologies: opportunities, challenges, and prospects. Frontiers in Microbiology, v. 7, p. 2106, 2017. https://dx.doi.org/10.3389/fmicb.2016.02106 


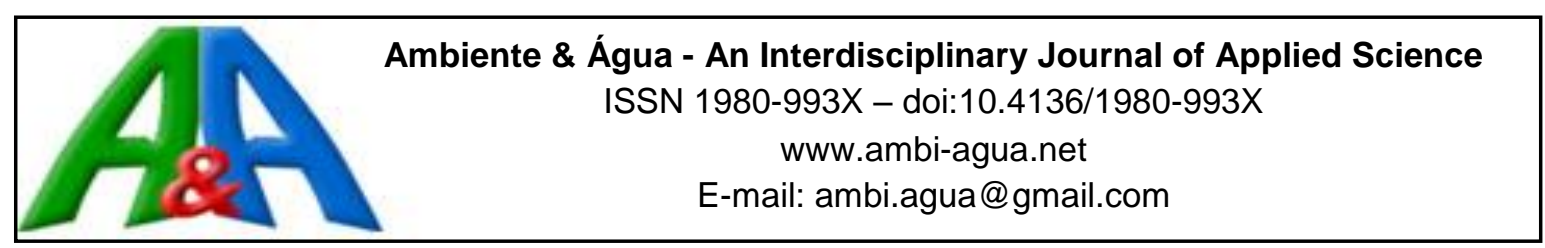

\title{
Removal of organic matter from pre-treated domestic sewage in anaerobic biological reactor by a combined system of electrolytic and biological aerobic treatment
}

\author{
ARTICLES doi:10.4136/ambi-agua.2349
}

Received: 26 Nov. 2018; Accepted: 10 Jun. 2019

\author{
Ariela Araujo Fonseca* ${ }^{(D)}$; Yovanka Pérez Ginoris ${ }^{(D)}$ \\ Norma Mendes Pinheiro Gontijo ${ }^{(D)}$; Marco Antonio Almeida de Souza \\ Universidade de Brasília (UnB), Brasília, DF, Brasil \\ Departamento de Engenharia Civil e Ambiental (ENC). \\ E-mail: ariela_fonseca@hotmail.com, yovanka.perez@gmail.com, \\ normabiomed@gmail.com, marcantoniosouza@gmail.com \\ "Corresponding author
}

\begin{abstract}
Biological processes are the most widespread methods for wastewater treatment. However, they are limited in their ability to degrade toxic and refractory pollutants, contaminants that electrochemical processes can remove. Therefore, this research explored the possibility of treating sewage by an anaerobic biological process followed by an aerobic system integrated to an electrolytic process. Three sequential batch reactors were operated in an automated way. Each of three reactors represented a process: aerobic biological treatment (BR); electrolytic treatment (ER); and a combination of both, the bio electrolytic reactor (BER). Two phases were ran with different electrodes: (Phase 1) stainless steel and (Phase 2) graphite. The electric current was varied from 0.001 to $0.100 \mathrm{~A}$. COD, TS, SS, turbidity, and the zooplankton community were monitored. The highest organic matter removal efficiencies were $86 \%, 79 \%$ and $87 \%$ for BR, ER and BER, respectively. The best weekly BER efficiencies for COD removal were $90 \%$ and $98 \%$, with current densities of $0.27 \mathrm{~A} / \mathrm{m}^{2}$ (Phase 1) and $0.05 \mathrm{~A} / \mathrm{m}^{2}$ (Phase 2). The main conclusions about bio electrolytic process were: (1) it did not achieve organic matter removal high enough to justify its application; (2) inert electrodes are the more indicated; and (3) the zooplankton community was affected by the electric current.
\end{abstract}

Keywords: bioelectrolytic reactor, electrolytic treatment, removal of organic matter.

\section{Remoção de matéria orgânica de esgoto doméstico pré-tratado em reator biológico anaeróbio por um sistema combinado de tratamento eletrolítico e biológico aeróbio}

\section{RESUMO}

Os processos biológicos são os métodos mais difundidos para o tratamento de águas residuárias. No entanto, eles têm limitações para degradar poluentes tóxicos e refratários, contaminantes, que os processos eletroquímicos podem remover. Portanto, o objetivo da pesquisa foi verificar a possibilidade de tratamento de esgoto por um processo biológico anaeróbio seguido de um sistema aeróbio integrado a um processo eletrolítico. Três reatores 
sequenciais em batelada foram operados de maneira automatizada. Cada um dos três reatores representou um processo: tratamento biológico aeróbico (RB); tratamento eletrolítico (RE); e a fusão de ambos, o reator bioeletrolítico (RBE). Duas fases foram executadas com diferentes eletrodos: (Fase 1) de aço inoxidável e (Fase 2) de grafite. A corrente elétrica foi variada de 0.001 a 0.100 A. DQO, ST, SS, turbidez e comunidade zooplanctônica foram monitorados. As maiores eficiências de remoção de matéria orgânica foram $86 \%, 79 \%$ e $87 \%$ para BR, RE e $\mathrm{RBE}$, respectivamente. As melhores eficiências semanais de RBE para remoção de DQO foram $90 \%$ e $98 \%$ com densidades de corrente de $0.27 \mathrm{~A} / \mathrm{m}^{2}$ (Fase 1) e $0.05 \mathrm{~A} / \mathrm{m}^{2}$ (Fase 2). As principais conclusões sobre o processo bioeletrolítico foram: (1) eles não atingem remoção de matéria orgânica tão alta que justifique sua aplicação; (2) os eletrodos inertes são os mais indicados; e (3) a comunidade zooplanctônica foi afetada pela corrente elétrica.

Palavras-chave: reator bioeletrolítico, remoção de matéria orgânica, tratamento eletrolítico.

\section{INTRODUCTION}

The most-used processes for sewage treatment are biological treatments. However, these treatment processes have limitations in the removal of organic matter and solids, require a great deal of space, are time-consuming, and do not tend to be entirely effective against barely biodegradable and toxic pollutants (Martínez-Huitle et al., 2015). Further, biological methods also give low degradation efficiency in the treatment of highly concentrated and biorefractory pollutants, especially certain industrial wastewaters containing toxic components such as pesticides, because the activity of microorganisms is inhibited by toxicity. To treat this kind of wastewater, many physical and chemical methods have been introduced (Liu et al., 2010). In relation to anaerobic treatment, its effluents have high BOD concentrations, color and unpleasant odor, resulting in the need for complementary treatment. Therefore, there is a global trend to improve existing sewage treatment processes and continuously enhance the quality of treated effluents, with the purpose of adapting them to environmental requirements and water reuse.

Electrolytic treatment is one of the complementary alternatives to anaerobic biological treatment. In the last few years, electrolytic treatment was associated with the anaerobic or aerobic biological treatment. According to Ganzenko et al. (2014), these combined processes are studied before or after electrolytic treatment. In the first case, the goal is to make biodegradable the effluent for subsequent biological treatment. In the second case, the electrolytic process is located after the biological treatment to remove pollutants and their intermediates, which are refractory to anaerobic bacteria. Electrolytic treatment can reduce the effluents' toxicity by transforming persistent substances into biodegradable substances. In addition to the efficiency of electrolytic treatment, this kind of sewage treatment also has several advantages: it uses compact reactors with a smaller physical footprint requiring less landspace; there is no need for auxiliary chemicals, which obviates the need to store and transport such chemicals it can be easily combined with other conventional water treatment technologies; and it can be fully automated (Garcia-Segura et al., 2018).

Electrolytic treatment therefore allows the increasing of the efficiency of conventional biological treatment (Claro et al., 2010). Electrolytic processes have been an option for the wastewater treatment, and they can be used as a single process or coupled with other processes. This type of treatment can be adapted to various applications and can be easily combined with other technologies, and its modular and compact design makes it attractive for the treatment of decentralized wastewater (Radjenovic and Sedlak, 2015). Materials commonly used to make the electrodes are aluminum or iron, because they are cheap and easy to access. However, other materials have been studied, such as oxides of graphite, titanium, ruthenium, platinum, copper

Rev. Ambient. Água vol. 14 n. 4, e2349 - Taubaté 2019 
and zinc. When an electrode, during the electrolysis process, does not undergo changes in its structure, even under certain conditions, it is called an inert electrode and its function is the simple exchange of electrons with the solution; examples of inert electrodes are graphite and platinum. The active electrode, besides transferring electrons, chemically participates in electrolysis, being also modified by the action of the electric current, forming metallic ions; examples of active electrodes are iron and copper. In oxidation processes, researchers have been using graphite electrodes, because of their high porosity, which results in a larger surface area. In addition, electrodes composed of platinum, aluminum and steel have been extensively applied (Mattiusi et al., 2015).

The main purpose of this paper was to study the possibility of performing the effluent treatment of an anaerobic biological system by the aerobic biological treatment combined with the electrolytic process, known as bio electrolytic treatment. Another purpose was to verify if there is synergy between the aerobic biological process and the electrolytic process for the removal of organic matter from sewage. In addition, the zooplankton community was evaluated and compared in the aerobic biological process and in the integrated bio electrolytic process, and relations were explored between the relative abundances of the organisms groups with the performance of the sewage treatment processes.

\section{MATERIALS AND METHODS}

\subsection{Design and construction of the bench scale electrolytic system}

Figure 1 shows the schematic diagram of the experimental apparatus for operating the bench scale electrolytic system that was conceived for this research. A photograph of the complete experimental system installed in the laboratory can be seen in Figure 2. The system was composed of three glass reactors of 4 liters volume each; the useful volume was $3.6 \mathrm{~L}$. The adopted configuration was an activated sludge as an aerobic biological reactor (BR), an electrolytic reactor (ER) and a bio electrolytic reactor, which combined the two processes, activated sludge and electrolytic (BER). The system ran in an automated way and in sequential batches, each reactor running in parallel with others. The system operation was divided into two operational phases. In each phase, the type of electrodes used was alternated. At the first phase, as electrodes, brushed stainless steel $\mathrm{n}^{\circ} 430$, was used with a size of $13 \times 14 \mathrm{~cm}$, a thickness of $1.0 \mathrm{~mm}$, a density of $7.8 \mathrm{~g} / \mathrm{cm}^{3}$, and a resistivity of $0.06 \mu \Omega \mathrm{m}$. In the second phase of operation, the electrode applied was the pure graphite plate with density of $1.75 \mathrm{~g} / \mathrm{cm}^{3}$, resistivity of $7.5 \mu \Omega \mathrm{m}$, size of $13 \times 14 \mathrm{~cm}$, and thickness of $2.7 \mathrm{~mm}$. The automatic operation of the system was possible due to an Arduino microcontroller. This device had the function of controlling the operation of the cycles in the sequential batches, as well as the duration times of each batch phase, the filling and discharge of the reactors, activation of the aerators and the electric source. An Arduino Mega 2560 R3 was used due to the cost of acquisition and to fit the technical needs.

\subsection{Experimental design}

Due to the large variation in the domestic wastewater composition, synthetic wastewater (SW) was used to simulate domestic sewage pretreated by an anaerobic treatment. For this purpose, the effluent of a local study (Achaval, 2014) was chosen. Achaval (2014) developed a prototype of a compact wastewater treatment plant for single-family residential units. For the preparation of SW, the methodology used was that proposed by Torres et al. (1996) and used by Moura (2011) and Michelan (2006). For this research, an SW was used with approximately $265 \mathrm{mg}$ COD. $\mathrm{L}^{-1}$. The inoculum used in the first and second phase was the mixed liquor collected and transported from the return well of a biological aerobic reactor of the Sewage Treatment Plants of Brasília - South and North, respectively. 


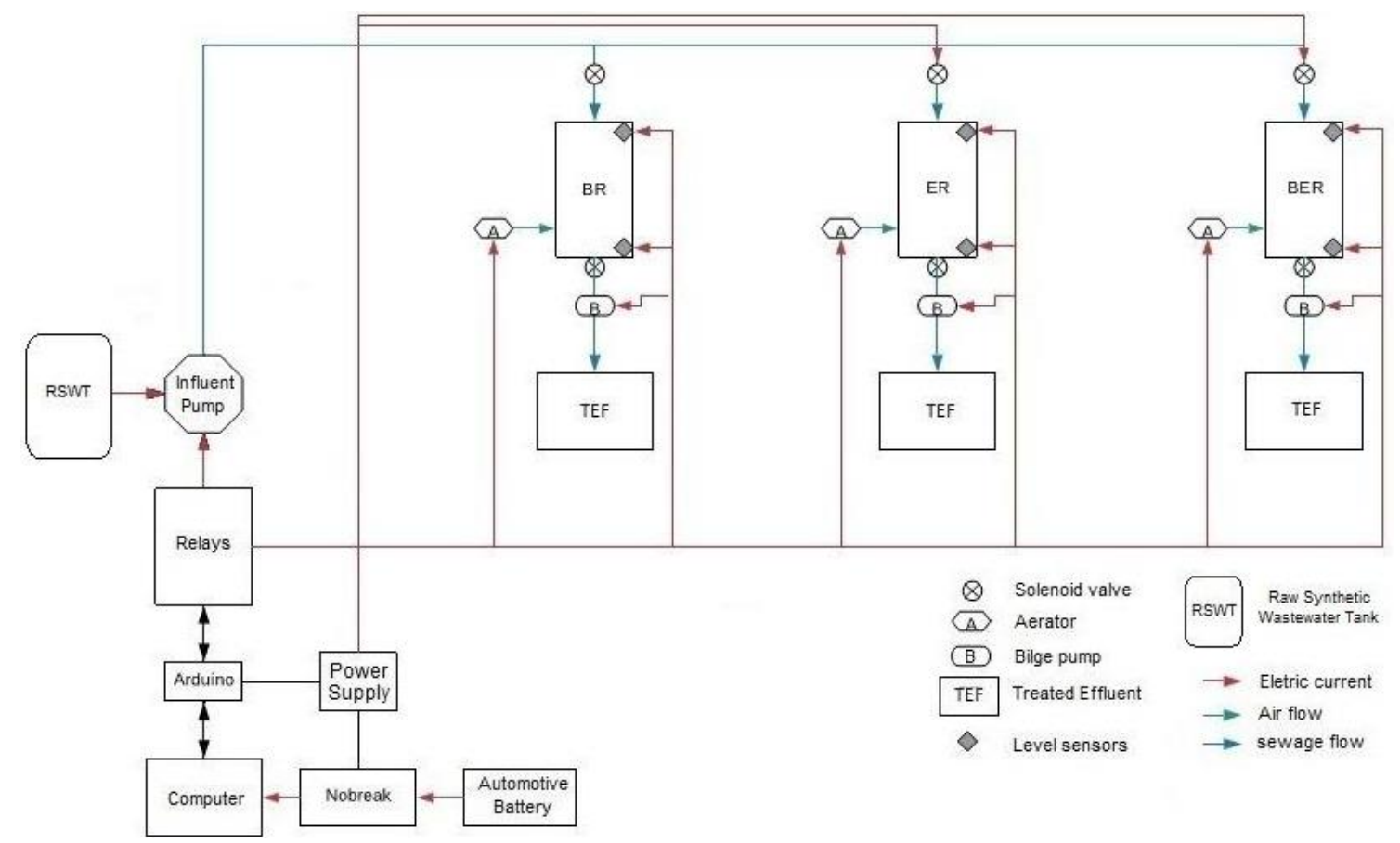

Figure 1. Schematic diagram of the experimental apparatus.

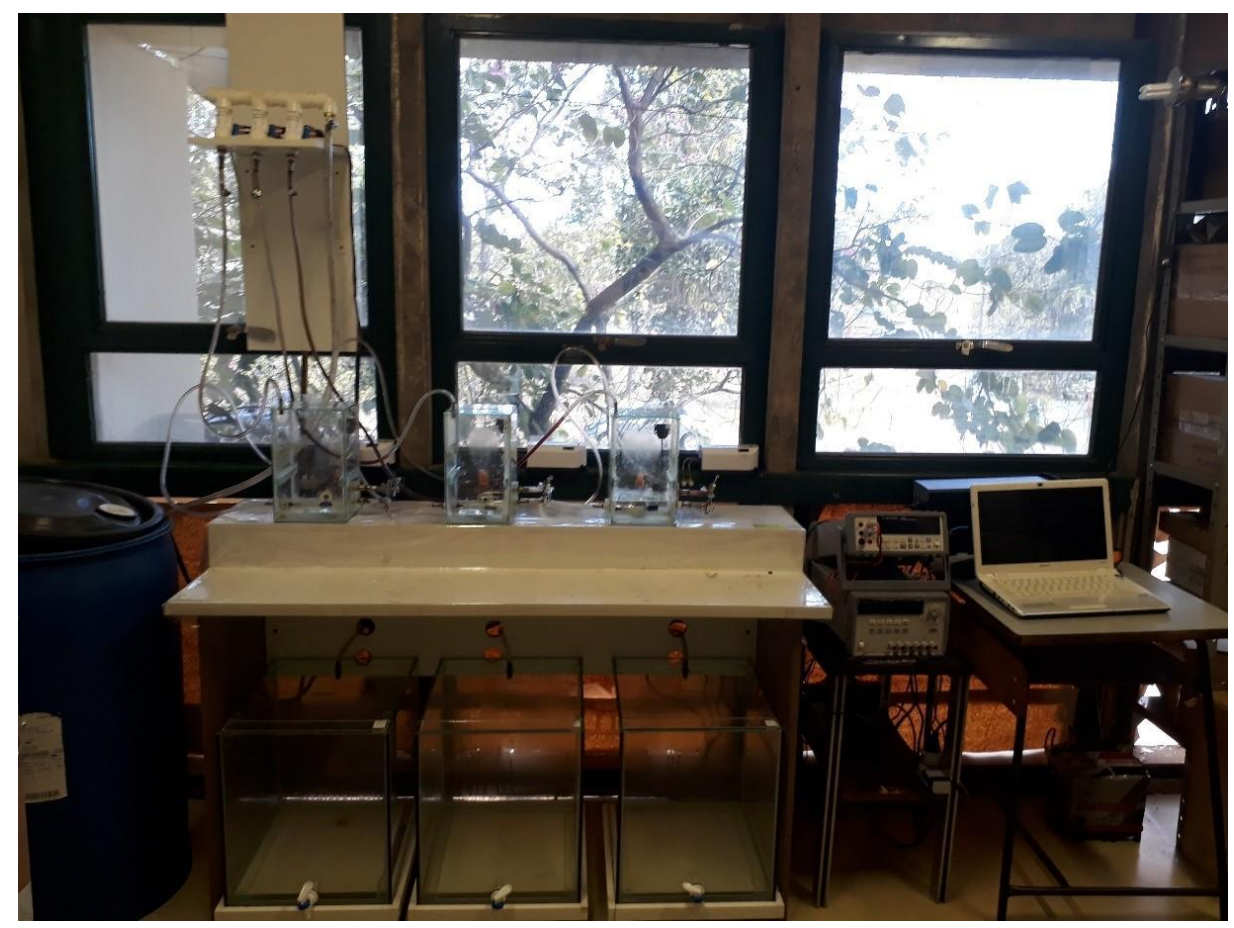

Figure 2. Photograph of the complete experimental system installed in the laboratory.

For the beginning of reactors operation, the inoculum was brought and introduced in the BR and the BER reactors, transferring the amount of 1.08 liters per reactor, equivalent to $30 \%$ of the useful volume of each reactor. During the day, the system was operated in two batches of three hours of reaction and one hour of sedimentation, totaling 4 hours of duration for each batch. During the night, only a single batch was carried out for 12 hours, with 11 hours of reaction and 1 hour of sedimentation. The filling and disposal steps were performed quickly at the beginning and end of each batch. This operation model was chosen to prevent system 
interruptions caused by failures in the electric power supply, which would result in the system reboot. In addition, the prototype operation model tried to reproduce a single-family sewage treatment system, in which during the night period the inlet flow is small or non-existent, resulting in a long duty cycle at night. Each system operational phase was fixed in 25 days. Every 5 days a different electric current was applied. Each application of electrical current band started on Monday and ended on Friday. There were no electric current applications on weekends. Each band of electric current applied weekly was called the "experimental condition". Therefore, a different experimental condition was applied each week of operation, which corresponds to the electric current ranges previously defined for the experiment. The current ranges were suggested according to the electric source specifications and the literature studied. Concerning the current variation in the reactors and the operation of each cycle, it is possible to understand the operation model in Tables 1 and 2.

Table 1. Operation of Biological Reactor (BR), Electrolytic Reactor (ER) and Bio Electrolytic Reactor (BER).

\begin{tabular}{lcccccc}
\hline Stages of the cycle & Duration & \multicolumn{2}{c}{ Electric Current (A) } & Aeration & \multicolumn{3}{c}{ Electrical Current (status) } \\
\hline & & BR, ER e BER & & BR & ER & BER \\
\hline Filling & $1 \mathrm{~min}$ & - & On & Off & Off & Off \\
Reaction & $180 \mathrm{~min}$ & 0.001 a 0.100 & On & Off & On & On \\
Sedimentation & $60 \mathrm{~min}$ & - & Off & Off & Off & Off \\
Disposal of effluent & $2 \mathrm{~min}$ & - & Off & Off & Off & Off \\
\hline
\end{tabular}

Table 2. Experimental conditions, current ranges and currents densities applied to the system during the operational phases.

\begin{tabular}{ccc}
\hline Experimental Conditions & Current ranges (A) & Current densities $\left(\mathbf{A} / \mathbf{m}^{2}\right)$ \\
\hline $\mathbf{1}^{\circ}$ Condition & 0.001 & 0.0549 \\
$\mathbf{2}^{\circ}$ Condition & 0.005 & 0.2747 \\
$\mathbf{3}^{\circ}$ Condition & 0.010 & 0.5494 \\
$\mathbf{4}^{\circ}$ Condition & 0.050 & 2.7473 \\
$\mathbf{5}^{\circ}$ Condition & 0.100 & 5.4945 \\
\hline
\end{tabular}

\subsection{Sampling and analyses performed on the effluent}

Samples were collected daily and weekly. The sample collection was carried out in the effluent inside the reactors (mixed liquor) and in the treated effluent. Sampling was performed in a composite manner, starting from the first cycle of the day. Simple samples were collected each cycle, and at the end of the day, the samples were homogenized and transferred to a specific bottle and refrigerated until the next day. This procedure was carried out from Monday to Thursday; on Friday, the samples collected were acidified to retain their characteristics until the analysis performed on Monday. All analysis were performed according to the standards established by the Standard Methods for the Examination of Water and Wastewater (APHA et $a l ., 2005)$. The analysis performed and the method followed for each one can be visualized in Table 3.

Table 3. Analysis performed on mixed liquor (ML) and effluent (EF).

\begin{tabular}{lccc}
\hline Parameter to be analyzed & Point of collect & Weekly frequency & Method \\
\hline Chemical demand for oxygen & EF & Daily & Colorimetric \\
Total suspended solids & ML / EF & 1 & Gravimetric \\
Turbidity & EF & 2 & Nephelometric Method \\
Dissolved oxygen & ML & Daily & Oximeter \\
Count of microorganisms & ML & 2 & Method of Madoni (1994) \\
\hline
\end{tabular}


As in the activated sludge system, the low illumination condition is not favorable for the development of the phytoplankton community; it was chosen to observe only the zooplankton community. Zooplankton monitoring was performed by the identification and counting of protozoa and metazoan, always in duplicate, presented in the mixed liquor of the BR and BER reactors. For each experimental condition, two micro fauna analysis corresponding to the beginning and the end of the electric current application in the reactors were performed. For identification and counting of zooplankton, the methodology proposed by Madoni (1994) was followed. In order to characterize the zooplankton community present in the mixed liquor of the BR and BER reactors, the proper systematics for typical microorganisms of activated sludge systems was used, as proposed by Canler et al. (1999) and Madoni (1994). For this characterization, microorganisms were identified up to the gender level, and were grouped into eight groups as follows:

- Amoebas: Represented by the naked amoebas and testae amoebas of the Arcella genus;

- Annelids: Represented by order oligochaeta, Aelosoma genus;

- Crawling ciliates: Represented by aspidisca, chilodonella, drepano monas, Trachelophyllum and Trochilia genuses;

- Free swimming ciliates: Represented by the genera Colpidium, Tetrahymena and Litonotus;

- Attached Ciliates: Represented by Epistylis, Vorticella, Podophrya, Tokophrya and Acienta genuses;

- Big flagellates: Represented by Peranema genus;

- Nematode: Represented by Nematodes genus; and

- Rotifers: Represented by Digononta e Monogononta orders;

To facilitate the results exhibition in the graphs, the groups of organisms were abbreviated. Table 4 shows abbreviation subtitles.

Table 4. Subtitle of the names of the groups of microorganisms.

\begin{tabular}{lc}
\hline Organism & Abbreviation \\
\hline Amoebae & AM \\
Annelids & AN \\
Crawling ciliates & CC \\
Free swimming ciliates & FSC \\
Attached Ciliates & AC \\
Big Flagellates & BF \\
Nematodes & NE \\
Rotifers & RO \\
\hline
\end{tabular}

\section{RESULTS AND DISCUSSION}

The use of electrodes of different materials promoted changes in the characteristics of treated effluents. The first phase (with stainless steel) lasted four weeks due to operational problems. The second phase (with pure graphite) ran normally under the predicted conditions during five weeks. Table 5 shows the weekly COD removal efficiency values obtained at the three points analyzed during the two operational phases. 
Table 5. Weekly medium COD removal efficiency values, obtained at the three points analyzed during the two phases of the experimental system operation.

\begin{tabular}{lcccccc}
\hline \multicolumn{7}{c}{ COD Removal Efficiency (\%) } \\
\hline & $\mathbf{1}^{\circ}$ phase (with stainless steel) & \multicolumn{2}{c}{$\mathbf{2}^{\circ}$ phase (with pure graphite) } \\
\hline & BR & ER & BER & BR & ER & BER \\
\hline $\mathbf{1}^{\circ}$ Week & 90.44 & 81.35 & 78.09 & 95.10 & 67.60 & 98.20 \\
$\mathbf{2}^{\circ}$ Week & 82.01 & 53.90 & 89.69 & 87.40 & 70.30 & 85.70 \\
$\mathbf{3}^{\circ}$ Week & 85.14 & 65.88 & 80.77 & 79.20 & 73.20 & 81.00 \\
$\mathbf{4}^{\circ}$ Week & 78.35 & 77.07 & 72.45 & 83.70 & 90.20 & 80.90 \\
$\mathbf{5}^{\circ}$ Week & - & - & - & 82.00 & 92.20 & 88.20 \\
\hline
\end{tabular}

$\mathrm{BR}=$ Biological reactor, $\mathrm{ER}=$ Electrolytic reactor, $\mathrm{BER}=$ Bioelectrolytic reactor.

It was noticed that the BER best performance in the first phase was reached on the second week of operation, while in the second phase the best performance occurred in the first week. In the first phase, reactive electrodes of stainless steel were used, so it is probable that, due to the electrolysis process, part of the iron that comprises this electrode has been lost in the water, added to the sludge and precipitate, avoiding that it was discarded with the effluent. According to Al-Shannag et al. (2013), when iron is used in the electrocoagulation process, the formation of Fe (III) ions is favorable. In a basic environment, simultaneous formations of ferric hydroxide/oxides are also expected. Precipitates of formed $\mathrm{Fe}$ (III) hydroxides have a coagulating character better than Fe (II) hydroxide, because $\mathrm{Fe}(\mathrm{OH})_{3}$ is more stable than $\mathrm{Fe}(\mathrm{OH})_{2}$, so the removal efficiency increases. It is important to note that the samples submitted to the COD tests were aerated during the batch reaction phase. This suggests that the effluent from the ER and BER reactors contained only $\mathrm{Fe}^{3+}$, which does not interfere in the COD test because these cations are in their maximum oxidation state. In the second phase, where graphite electrodes were used, the optimum efficiency value was reached in the first week. This can indicate that, with a current equivalent to $0.001 \mathrm{~A}$, the microorganisms may not have been affected abruptly and current may have acted on a positive threshold for the micro fauna. However, in the first and second phases, during the weeks of operation, there were oscillations in COD removal performances, suggesting that the microorganisms present in the BER reactor may have been affected by the variations and increasing of the electric current.

Regarding the ER reactor in the first phase of operation, the best COD removal performance occurred in the first week. In the second phase, it occurred in the last operational week. The result obtained in the first phase was unexpected, because in the electrolytic treatment the higher the electric current applied, the greater the treatment efficiency. However, considering the usage of stainless steel electrodes in this phase, it is known that due to the oxidization of the electrode, an iron release occurs which may have caused interference in the COD analysis.

In the second phase, it was noticed that, with the increase of the electric current during the weeks of operation, the ER reactor's COD removal efficiency increased, confirming the premise of the electrolytic treatment. The COD reduction in the ER reactor increased with current density. This can be explained by the increase in the release of metallic ions with the increase in current density, which improves COD reduction. (Senthilkumar et al., 2012). The BR reactor showed similar behavior in the two phases of operation. There were fluctuations in the removal values and a pattern of decreased performance was noted over the weeks of operation. This fact suggests an affectation of the microbial community in the BR reactor probably due to operational factors.

The overall COD removal performance in the first phase of the four weeks of operation were $84 \%, 70 \%$ and $80 \%$ of COD removal in BR, ER and BER reactors, respectively. In the 
second phase, overall performance removal of the five weeks of operation was $85 \%, 79 \%$ and $87 \%$ in the reactors BR, ER and BER, respectively. The best performance was obtained in the second phase of operation, and BR and BER reactors presented similar results. The performance achieved by the BR reactor in the first and second phases, 84 and $85 \%$ of COD removal, was lower than that demonstrated by Santos (2005), who worked with Sequential Batch Reactor (SBR) under different sludge ages in bench scale for domestic wastewater treatment and reached $90 \%$ in COD removal. The BR reactor performances in both phases also were lower than that achieved by Chonova et al. (2016), who evaluated the efficiency of biological treatment with a conventional activated sludge system for domestic wastewater treatment and reached 95.4\% COD removal. Comparing this reactor with a full-scale plant, it was found that the BR reactor also had an efficiency lower than expected, since the activated sludge reactor of the Brasília South Sewage Treatment Plant obtained a COD removal of 92.4\% in the year 2013 (CAESB, 2013). The oscillations in COD removal efficiencies in the BR reactor in the two phases can be attributed to the model of operation adopted in the system. During the night, only a single and long batch was carried out for 12 hours, with 11 hours of reaction and 1 hour of sedimentation. Therefore, it can be considered that the biomass was affected and the F/M ratio was reduced drastically overnight due to batch duration. According to Von Sperling (1997), when the F/M ratio is low, when the amount of food supplied to biomass is reduced, the endogenous respiration rate prevails in the system. In this case, in order to ensure the survival of microorganisms, oxygen consumption by the cells occurs to degradation of the substrate present in the bacterial cell itself.

On the other hand, the COD removal efficiency reached by ER reactor was $70 \%$ in the first phase. This result is close to that of the research of Rodrigues et al. (2001), who worked with iron and aluminum electrodes treating effluent from a UASB reactor and obtained COD removal efficiency of $74.74 \%$ in the reactors. This result also is compatible with the results obtained by Daghrir et al. (2014), who worked with bored doped diamond anodes treating effluent from domestic wastewater and obtained COD removal efficiency of $78.2 \%$. Furthermore, the work of Al-Shannag et al. (2013) may be cited, who operated a system to enhance the COD and nutrient removal of a secondary clarifier of municipal wastewater, using electrocoagulation technique with an iron electrode, and obtained steady removal efficiencies of COD and nutrients exceeding $89 \%$, surpassing the result of this research. In the second phase, the efficiency result of the ER reactor was higher than that of Rodrigues et al. (2001), very close to that found by Daghrir et al. (2014), and smaller than that found by Al-Shannag et al. (2013). Briefly, in the second phase, due to the characteristics of the electrodes, since they were inert, it was noticed that the increase of the COD removal occurred with the increase of the electric current, according to the rules of electrolysis. In the integrated biological and electrolytic process, Senthilkumar et al. (2012) obtained 80\% COD removal, the same result reached by the BER reactor in the first phase and lower than that of the second phase, which was $87 \%$.

Regarding the efficiency of Total Suspended Solids (TSS) removal, in the first phase $93 \%$ was removed in the BR, $47 \%$ in the ER and $95 \%$ in the BER reactor. In the second phase, the results were $84 \%$ in the BR, $38 \%$ in the ER and $76 \%$ in the BER reactor. It can be stated that the highest values of TSS removal were reached in the decantation of the BR and BER effluents. This was possibly due to the optimum sedimentation of the effluent and due to the fact that the reactors have biological solids inside them. In the first phase, there was the aggregation of dissolved iron in the BER biomass, promoting the retention of part of the solids inside the reactor. In the ER, the mean removal was lower during the two phases, which may have been caused by the accumulation of material from the SW inside the reactor.

The turbidity results obtained in the treated effluents of the reactors indicate that the values corresponding to the effluent from the biological reactor were similar in the two phases, 9 and

Rev. Ambient. Água vol. 14 n. 4, e2349 - Taubaté 2019 
8 NTU (Nephelometric Turbidity Unit), for the first and the second phase. However, in the first phase of operation, the highest discrepancy between turbidity values of the effluents was observed, 5 and 40 NTU for the ER and the BER, and in the second phase, the values were 13 and 11 NTU. The discrepancy between the values of the first and second phases can be attributed to the use of reactive electrodes and to their rapid wear. Concerning dissolved oxygen (DO) concentrations in the reactors, it was verified that the values were above $2 \mathrm{mg} . \mathrm{L}^{-1}$, the minimum concentration recommended by the USEPA (1993). In the first phase, the DO concentration remained at $5.75 \mathrm{mg} . \mathrm{L}^{-1} \mathrm{O}_{2} \pm 0.73$ in the $\mathrm{BR}$ and $6.14 \mathrm{mg} . \mathrm{L}^{-1} \mathrm{O}_{2} \pm 0.29$ in the BER reactor. In the second phase, these values were $5.99 \mathrm{mg} . \mathrm{L}^{-1} \mathrm{O}_{2} \pm 0.27$ and $5.95 \mathrm{mg} . \mathrm{L}^{-1} \mathrm{O}_{2}$ \pm 0.30 in the BR and the BER reactors, respectively. Therefore, aeration conditions were maintained for the development of heterotrophic aerobic biomass in the reactors.

The first phase of operation lasted four weeks. Consequently, four experimental conditions were applied in this phase, because each week represented an experimental condition. Stainless steel electrodes were used. In each week of operation two micro fauna analysis corresponding to the beginning and the end of the current application in the BR reactors and the BER were carried out. In the second stage of operation, pure graphite rigid electrodes were used. This phase lasted five weeks, where five experimental conditions were applied. However, the quantitative and qualitative characterization of the biomass began to be performed from the second week of operation, which represents the second experimental condition applied.

During the first operational phase, there were significant variations in the reactors' micro fauna. At the beginning of the first week of operation, corresponding to the first experimental condition, it was observed that in the two reactors, BR and BER, there was little variety of group of organisms (Figure 3). However, Monogononta and Digononta, organisms of the rotifers class, presented themselves as dominant species. At the end of the period, an increase in micro fauna diversity and in the ciliates relative frequency was noticed, accompanied by a reduction in the abundance of rotifers.

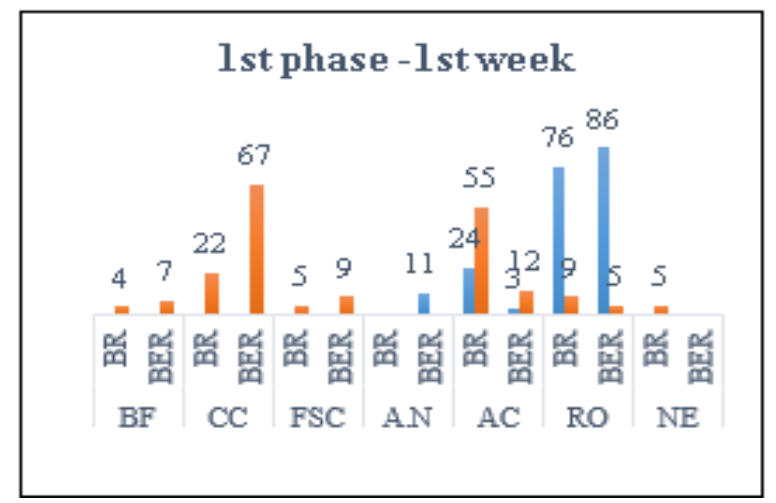

Figure 3. Microorganisms relative frequency in $\mathrm{BR}$ and BER of the third week of operation corresponding to the third experimental condition applied. The labels of the organisms are in accordance with Table 4.

In the beginning of the second experimental condition, at the first phase, the crawling ciliates appeared with the highest relative frequencies in the BR and BER reactors (Figure 4). At the end of the period, it was noticed that species diversity was affected in the two reactors, but the BR was more affected. It was also noticed that the amoebas became dominant in the BR and BER reactors. During this experimental condition, at the second phase, it was noticed at the beginning that the dominant groups were rotifers and attached ciliates, in the BR and BER reactors. However, at the end of this period the attached ciliates, a dominant species at the 
beginning of the week, gave way to the rotifers and swimming ciliates, which predominated in the BER. This behavior was similar in the two reactors, so this fact was not due to the electric current application.

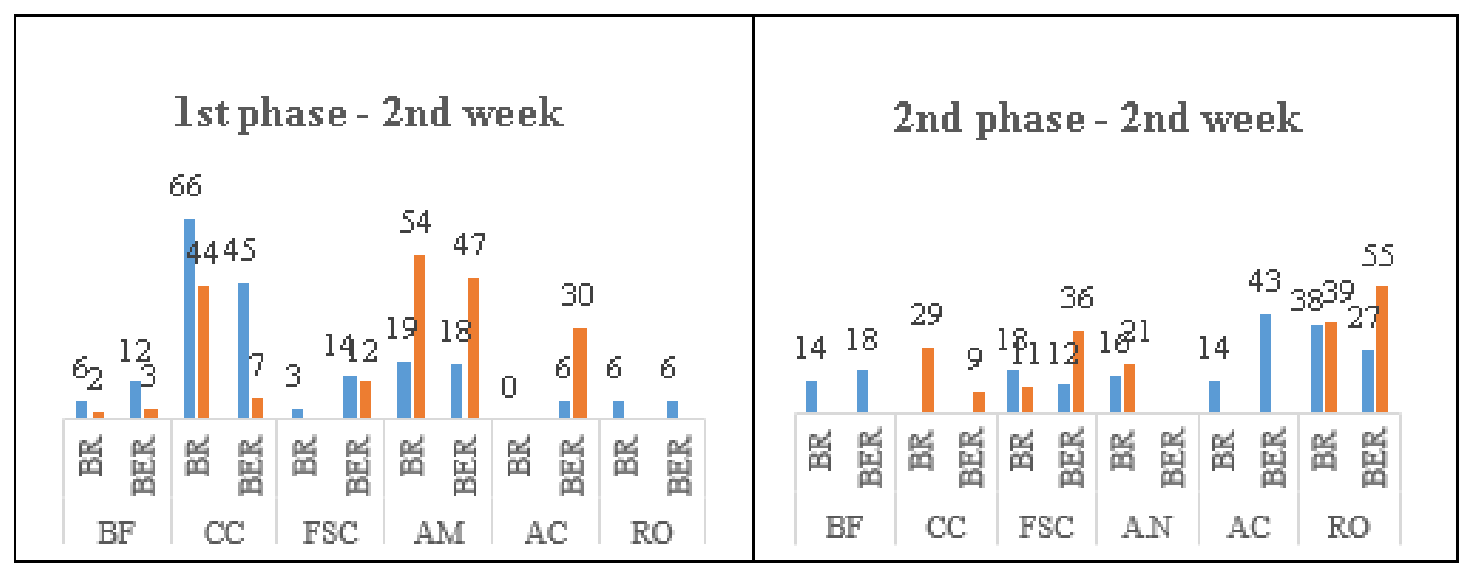

Figure 4. Microorganisms' relative frequency in the BR and BER during the second week of operation, corresponding to the second experimental condition applied. The labels of the organisms are in accordance with Table 4.

During the third experimental condition, at the first phase, at the beginning it was observed that the two reactors presented similar diversity (Figure 5). At the end of this period, no affectation of the microorganisms was observed with respect to their diversity, being that the predominant class in the reactors was the attached ciliates of the genus Epistylis. In the third experimental condition, at the second phase, a decrease in the number of species of microorganisms presented in the BER reactor was observed. The BR reactor remained stable in relation to the diversity of groups present. At the end of this period, there was a recovery of the reactors with the development of species and with the increase of the microorganisms diversity.

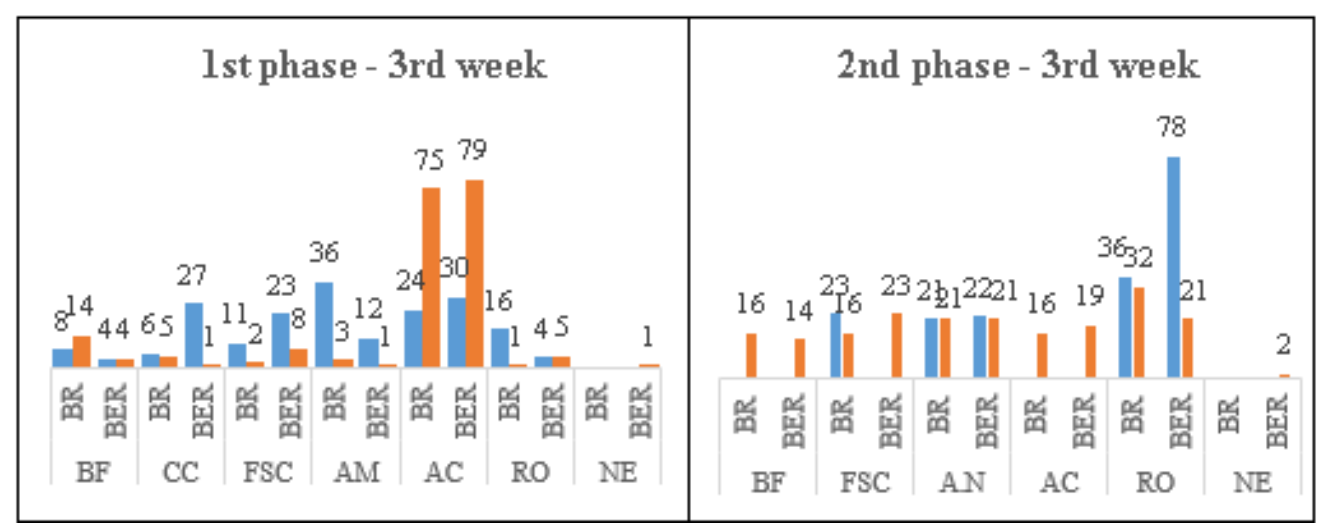

Figure 5. Microorganisms' relative frequency in the BR and BER during the third week of operation, corresponding to the third experimental condition applied. The labels of the organisms are in accordance with Table 4.

Still referring to the first phase of operation, in the fourth experimental condition, the attached ciliates were the dominant species, but in the BER, also amoebas and nematodes were found (Figure 6). The rotifers and annelids disappeared in the BER, whereas in the RB the relative frequencies of these organisms increased, a fact that reinforces the possibility of the electric current influencing the microorganisms. The reduction of rotifers and annelids in BER may be indicative of damage to the system performance once these organisms represent satisfactory aeration conditions and effluent quality. During the fourth experimental condition,

Rev. Ambient. Água vol. 14 n. 4, e2349 - Taubaté 2019 
at the second phase, the predominance of rotifers and annelids in both reactors was observed. At the end of the period, it was noticed that the rotifers were dominant in the BER. However, there was an annelids community increasing, represented by Aelosomas.

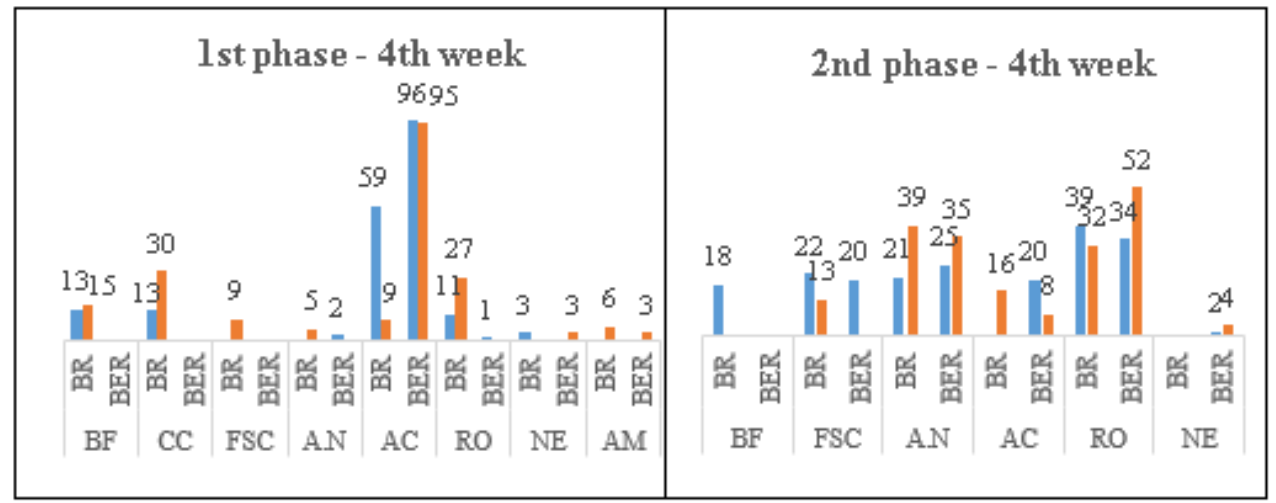

Figure 6. Microorganisms' relative frequency in the BR and BER during the fourth week of operation, corresponding to the fourth experimental condition applied. The labels of the organisms are in accordance with Table 4.

Finally, at the beginning of the fourth experimental condition, it was observed in the BER a diversity reduction of microorganisms (Figure 7). At the end of this period, the BER showed the same amount of species present at the beginning of this experimental condition for the attached ciliates. At the beginning of the fifth and final experimental condition evaluated, the annelids were the dominant group in the two reactors. At the end of the period, the BER reactor showed the highest reduction in the diversity of microorganisms presented in the biomass of this reactor, with only two species, rotifers and annelids, which can be associated to the negative effect of the electric current on the BER. It is suggested that there was interference of the electric current in the microbial metabolism in the first and second phase of operation. However, it cannot be stated to what extent electrostimulation of microorganisms positively or negatively affected the biomass.

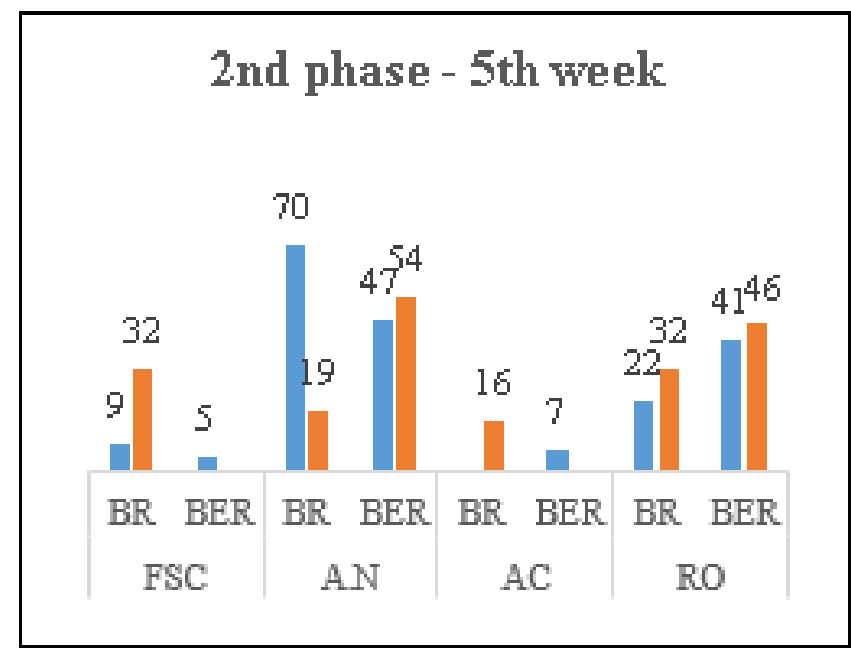

Figure 7. Microorganisms' relative frequency in the BR and BER of the fifth week of operation, corresponding to the fifth experimental condition applied. The labels of the organisms are in accordance with Table 4. 
In the first stage of operation, the formation of an iron hydroxide precipitate increased according to the increase of the applied electric current. Therefore, it is hard to make inferences from the COD values, since it is known that this analysis was impaired mainly in the last experimental condition with the highest electric current value tested. It can be suggested that the experimental conditions imposed on the BER reactor contributed to affect the zooplankton community. It can be affirmed that part of the oxygen that was being supplied to this reactor was consumed in the iron oxidation. Thus, it is probable that the aerobic degradation of organic matter and the nitrification process itself have been affected, reaching anoxic conditions in the system.

According to Thrash and Coates (2008), studies indicate that electrical stimulation can negatively affect growth and microbial activity; however, using appropriate currents, it is possible to promote microbial metabolism. Wei et al. (2011) demonstrated that the heterotrophic bacterial community was not significantly affected when the applied current density was less than $6.2 \mathrm{~A} / \mathrm{m}^{2}$, but was partially inactivated at current densities above 12.3 $\mathrm{A} / \mathrm{m}^{2}$. The current densities applied in the first and second phase of operation in this study $\left(0.0549,0.2747,0.5495,2.7473\right.$ and $\left.5.4945 \mathrm{~A} / \mathrm{m}^{2}\right)$ were lower than $6.2 \mathrm{~A} / \mathrm{m}^{2}$. Therefore, it would be expected that in the studied system there would be no immediate inactivation of microorganisms, a process that occurred gradually with the increase of the applied electric current. According to Matsunaga et al. (1992), electrical stimulation can cause negative effects on bacteria, directly oxidizing intracellular constituents without destroying their membranes, leading to cellular inactivation. High electrical current can also cause irreversible permeability of the cell membrane and subsequent release of essential cytoplasmic constituents (Drees et al., 2003). In addition, the literature indicates that electrolysis generates products derived from abiotic reactions on the electrode surface that may influence microbial metabolism, such as hydrogen peroxide, which may inhibit microbial metabolic activities (Thrash and Coates, 2008).

However, during the system operation, it was verified that the bio electrolytic reactor obtained similar values in terms of COD removal, and sometimes it was higher than the biological reactor. This may indicate a positive interaction between the zooplankton community in the bio electrolytic reactor and the electrical current application. However, it was not possible to state through this work that this interaction is beneficial for microorganisms.

\section{CONCLUSIONS}

The differences between COD removal in the bio electrolytic process during the two phases came from the different application of materials of the electrodes and due to the different origins of the inoculum used. The best results were achieved with rigid pure graphite electrodes, suggesting that non-reactive electrodes are more indicated for the process. According to the microbiological analysis, it was possible to identify that the zooplankton community was progressively affected due to electric current application in the bio electrolytic reactor during system operation. This fact was confirmed by the drastic reduction of diversity and relative frequency of the zooplankton community, indicating a possible electric current interference in the microbial metabolism during operation. With the design of the bio electrolytic reactor proposed in this research, this reactor did not reach sufficiently high organic matter removal efficiency when compared to the efficiency of the biological reactor to justify its application. However, even in this configuration (electrolytic and biological treatment in the same vessel), it is expected that such behavior can be improved when treating an effluent containing a toxic or recalcitrant compound.

As for the electrolytic reactor, the results suggest that, even under very low electrical currents, it was possible to achieve high COD removal rates under the conditions studied. It

Rev. Ambient. Água vol. 14 n. 4, e2349 - Taubaté 2019 
should be remembered that one of the criticisms of the electrolytic reactor treating sewage is that its energy consumption is supposedly very high.

In order to subsidize future works on the electrolytic and bio electrolytic treatment applied to the treatment of sewage, some recommendations are suggested. For example, a BER test in separate reactors, with the electrolytic treatment preceding the biological reactor and vice versa. In addition, it is also proposed to evaluate the bio electrolytic reactor efficiency in order to promote the degradation and removal of difficult compounds to treat.

\section{ACKNOWLEDGEMENTS}

The authors would like to express their gratitude for the financial support from the Brazilian agencies CNPq and FINEP and for the aid to the development of this research from the Brazilian Federal District's Water Supplier and Sanitation Company (CAESB).

\section{REFERENCES}

ACHAVAL, L. S. Desenvolvimento e avaliação de um protótipo de estação compacta para tratamento de esgoto em unidades residenciais unifamiliares. 2014. 191f. Dissertação (Mestrado em Tecnologia Ambiental e Recursos Hídricos) - Departamento de Engenharia Civil e Ambiental, Universidade de Brasília, Brasília, DF, 2014.

AL-SHANNAG, M.; BANI-MELHEM, K.; Zaid AL-ANBER, Z. Enhancement of CODNutrients Removals and Filterability of Secondary Clarifier Municipal Wastewater Influent Using Electrocoagulation Technique. Separation Science and Technology, v. 48, n. 4, p. 673-680, 2013. https://dx.doi.org/10.1080/01496395.2012.707729

APHA; AWWA; WEF. Standard Methods for the Examination of Water and Wastewater. 21. ed. Washington, 2005.

CAESB. Sinopse do Sistema de Esgotamento Sanitário do Distrito Federal. 26. ed. 2013. Available at: https://pt.scribd.com/document/340216176/SIESG-2013-Para-Intranet. Access: 04 Feb. 2018.

CANLER, J. P.; PERRET, J. M.; DUCHENE, F.; COTTEAUX, E. Aide au Diagnostic des Stations d'Épuration par I'observation Microscopique des Boues Activées. Lyon: Cemagref Editions, 1999. 160p.

CHONOVA, T.; KECK, F.; LABANOWSKI, J.; MONTUELLE, B.; RIMET, F.; BOUCHEZ, A. Separate treatment of hospital and urban wastewaters: A real scale comparison of effluents and their effect on microbial communities. Science of the Total Environment, v. 542, p. 965-975, 2016. https://dx.doi.org/10.1016/j.scitotenv.2015.10.161

CLARO, E. M. T.; OTENIO, H. M.; BIDÓI, A D. E.; SILVA, G. M. M. N.; SANTOS, V. Avaliação em escala laboratorial da aplicação do processo eletrolítico em efluente de lagoa de estabilização de esgoto urbano. Química Nova, v. 33, p. 557-561, 2010.

DAGHRIR, R.; DROGUI, P.; TSHIBANGU, J. Efficient treatment of domestic wastewater by electrochemical oxidation process using bored doped diamond anode. Separation and $\begin{array}{llllll}\text { Purification Technology, } & \text { v. 131, p. } & \text { 79-83, }\end{array}$ https://dx.doi.org/10.1016/j.seppur.2014.04.048

DREES, K. P.; ABBASZADEGAN, M.; MAIERA, R. M. Comparative electrochemical inactivation of bacteria and bacteriophage. Water Research, v. 37, p. 2291-2300, 2003. https://dx.doi.org/10.1016/S0043-1354(03)00009-5 
GARCIA-SEGURA, S.; OCON, D. J.; CHONG, N. M. Electrochemical oxidation remediation of real wastewater effluents - A review. Process Safety and Environmental Protection, v. 2, n. 3, p. 48-67, 2018. https://dx.doi.org/10.1016/j.psep.2017.09.014

GANZENKO, O.; HUGUENOT, D.; HULLESBUSCH, V. E.; ESPOSITO, G.; OTURAN, A. M. Processos Eletroquímicos de Oxidação Avançada e Biológicos para Tratamento de Águas Residuais: Uma Revisão das Abordagens Combinadas. Environmental Science and Pollution Research, v. 21, p. 8493-8524, 2014. https://dx.doi.org/10.1007/s11356014-2770-6

LIU, L.; ZHAO, G.; PANG, Y.; LEI, Y.; GAO, J.; LIU, M. Integrated Biological and Electrochemical Oxidation Treatment for High Toxicity Pesticide Pollutant. Industrial and Engineering Chemistry Research, v. 49, p. 5496-5503, 2010. https://doi.org/10.1021/ie100333v

MADONI, P. A sludge biotic index (SBI) for the evaluation of the biological performance of activated sludge plants based on the microfauna analysis. Water Research, v. 28, p. 6775, 1994. https://doi.org/10.1016/0043-1354(94)90120-1

MARTÍNEZ-HUITLE, A. C.; RODRIGO, A. M.; SIRÉS, I.; SCIALDONE, O. Single and Coupled Electrochemical Processes and Reactors for the Abatement of Organic Water Pollutants: A Critical Review. Chemical Reviews, v. 115, n. 24, p. 13362-13407, 2015. https://dx.doi.org/10.1021/acs.chemrev.5b00361

MATTIUSI, E. M.; KAMINARI, N. M. S.; PONTE, M. J. J. S.; PONTE, H. A. Behavior analysis of a porous bed electrochemical reactor the treatment of petrochemical industry wastewater contaminated by hydrogen sulfide. Chemical Engineering Journal, v. 275, p. 305-314, 2015. http://dx.doi.org/10.1016/j.cej.2015.03.138

MATSUNAGA, T.; NAKSONO, S.; TAKAMUKU, T.; BURGESS, J. G.; NAKAMURA, N.; SODE, K. Disinfection of drinking water by using a novel electrochemical reactor employing carbon-cloth electrodes. Applied and Environmental Microbiology, v. 58, p. 686-689, 1992.

MICHELAN, R. Influência do tipo de impelidor sobre o desempenho do reator anaeróbio em batelada sequencial com biomassa granulada tratando esgoto sintético. 2006. 181 p. Dissertação (Mestrado) - Escola de Engenharia de São Carlos, Universidade de São Paulo, São Carlos, 2006.

MOURA, B. R. Desempenho de um reator vertical de fluxo contínuo e leito estruturado com recirculação de efluente, submetido à aeração intermitente, na remoção de carbono e nitrogênio de um efluente sintético. 2011. 92p. Dissertação (Mestrado) Escola de Engenharia de São Carlos, Universidade de São Paulo, São Carlos, 2011.

RADJENOVIC, J.; SEDLAK, D. L. Challenges and Opportunities for Electrochemical Processes as Next Generation Technologies for the Treatment of Contaminated Water. Environmental, Science \& Technology, v. 49, n. 19, p. 11292-11302, 2015. https://dx.doi.org/10.1021/acs.est.5b02414

RODRIGUES, M. C.; BRITO, S. R.; SINOTI, A. L. L.; SOUZA, M. A. A. 2001 Tratamento eletrolítico de efluentes de efluentes de reatores anaeróbios. In: CONGRESSO BRASILEIRO DE ENGENHARIA SANITÁRIA E AMBIENTAL, 21., 2001, João Pessoa. Anais[...] São Paulo: ABES. 2001. p. 1-34. 
SANTOS, V. A. Comportamento de um Reator Sequencial de Batelada (SBR) sob estado estacionário dinâmico utilizando a idade do lodo como parâmetro de controle operacional. 2005. 418p. Tese (Doutorado) - Universidade Federal do Rio Grande do Sul, Porto Alegre, 2005.

SENTHILKUMAR, S.; BASHA, A. C.; PERUMALSAMY, M.; PRABHU, H. J. Electrochemical oxidation and aerobic biodegradation with isolated bacterial strains for dye wastewater: Combined and integrated approach. Electrochimica Acta, v .77, p. 171178, 2012. https://dx.doi.org/10.1016/j.electacta.2012.05.084

THRASH, J. C.; COATES, J. D. Review: direct and indirect electrical stimulation of microbial metabolism. Environmental Science Technology, v. 42, n. 11, p. 3921-3931, 2008. https://dx.doi.org/10.1021/es702668w

TORRES, P. L.; FORESTI, E.; VAZOLLER, R. 1996 Composición y uso de agua residual doméstica en reactores a escala de laboratório. In: CONGRESSO INTERAMERICANO DE INGENIERÍA SANITARIA Y AMBIENTAL, 25., 1996, Cidade do México, Anais[...] México: AIDIS, 1996. p. 1-9.

USEPA. Process design manual for nitrogen control. Cincinnati, 1993. EPA/625/R-93/010/.

VON SPERLING, M. Lodos ativados: Princípios do tratamento biológico de águas residuárias. Belo Horizonte: UFMG, 1997. 415p.

WEI, V.; ELEKTOROWICZ, M.; OLESZKIEWICZ, J. A. Influence of electric current on bacterial viability in wastewater treatment. Water Research. v. 45, p. 5058-5062, 2011. https://dx.doi.org/10.1016/j.watres.2011.07.011 


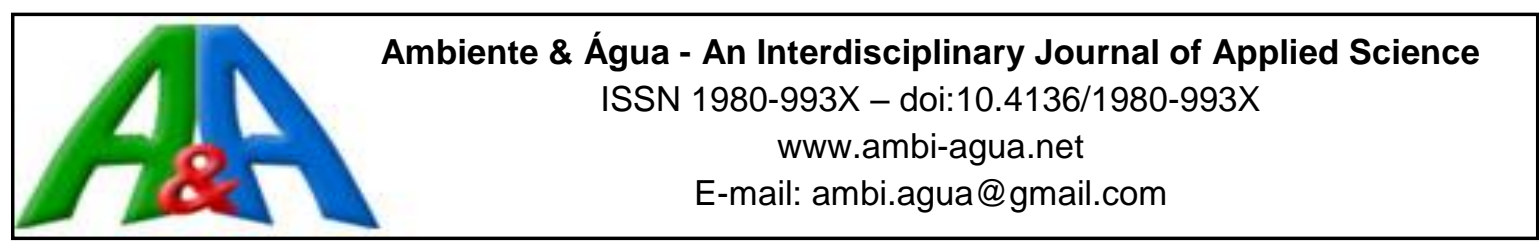

\title{
Sensitivity of hydrological connectivity in a semiarid basin with a high- density reservoir network
}

\author{
ARTICLES doi:10.4136/ambi-agua.2367
}

Received: 27 Nov. 2018; Accepted: 29 Apr. 2019

\author{
Cristian Epifanio Toledo $^{1 *(D)}$; Nayra Rodrigues Alcantara ${ }^{2}$ (D) \\ ${ }^{1}$ Universidade Estadual de Goiás (UEG), Palmeiras de Goiás, GO, Brasil \\ Departamento de Agronomia. E-mail: cristian.toledo@ueg.br \\ ${ }^{2}$ Universidade Federal de Goiás (UFG), Goiânia, GO, Brasil \\ Instituto de Patologia Tropical e Saúde Pública (IPTSP). \\ E-mail: bionaybio@gmail.com \\ *Corresponding author
}

\begin{abstract}
Water reservoirs, in general, have been considered to be the major cause of reduction of downstream hydrological connectivity in channels. Therefore, this study analyzed the sensitivity of hydrological connectivity in the Orós Reservoir hydrographic basin by using the ResNet model, designed to simulate the processes involved in fluvial hydrological connectivity in environments with a high density of reservoirs. The analysis of hydrological connectivity was performed with the model ResNetM, which simulated hydrological processes and considered hydrological connectivity between the reservoirs, according to the criteria established in this research. To identify the main elements that affect hydrological connectivity, sensitivity analysis (SI) was performed of some input parameters of the model. The sensitivity analysis indicated that the modification of the topology of the reservoir network was the variable that presented the highest sensitivity to hydrological connectivity, with a sensitivity value of 1.07 , followed by the runoff coefficient, which obtained a sensitivity of 0.8 . The modification of the rainfall and of the reservoir storage capacity, showed an intermediate sensitivity, with values of 0.46 and 0.45 , respectively. On the other hand, the parameters of potential evaporation and transmission loss showed the lowest sensitivity, obtaining values of 0.19 and 0.01 , respectively. In conclusion, the runoff coefficient and the reservoir network (change in the reservoir number of the network) were the parameters evaluated with the highest sensitivity of hydrological connectivity. Thus, the alteration of the landscape by man provides significant changes in river navigation between the reservoirs in the basin.
\end{abstract}

Keywords: climate changes, hydrological modeling, sensitivity analysis.

\section{Sensibilidade da conectividade hidrológica em uma bacia semiárida com uma rede de alta densidade de reservatórios}

\section{RESUMO}

Os reservatórios de água, em geral, têm sido considerados a principal causa de redução da conectividade hidrológica a jusante nos canais. Portanto, este estudo tem como objetivo analisar a sensibilidade da conectividade hidrológica na bacia hidrográfica do reservatório de Orós, utilizando o modelo ResNet, desenvolvido para simular os processos envolvidos na 
conectividade hidrológica fluvial em ambientes com alta densidade de reservatórios. A análise da conectividade hidrológica foi realizada com o modelo ResNetM, que simulou processos hidrológicos e considerou a conectividade hidrológica entre os reservatórios, de acordo com os critérios estabelecidos nesta pesquisa. Para identificar os principais elementos que afetam a conectividade hidrológica, foi realizada a análise de sensibilidade (SI) de alguns parâmetros de entrada do modelo. A análise de sensibilidade indicou que a modificação da topologia da rede de reservatórios foi a variável que apresentou maior sensibilidade à conectividade hidrológica, com um valor de sensibilidade de 1,07, seguido do coeficiente de escoamento, que obteve uma sensibilidade de 0,8. A modificação da precipitação pluviométrica e da capacidade de armazenamento do reservatório mostrou uma sensibilidade intermediária, com valores de 0,46 e 0,45 , respectivamente. Por outro lado, os parâmetros de potencial evaporação e perda de transmissão, apresentaram a menor sensibilidade, obtendo valores de 0,19 e 0,01, respectivamente. Conclui-se que o coeficiente de escoamento e a rede de reservatórios (mudança no número do reservatório da rede) foram os parâmetros avaliados com a maior sensibilidade de conectividade hidrológica. Assim, a alteração da paisagem pelo homem, proporciona mudanças significativas na navegação fluvial entre os reservatórios da bacia.

Palavras-chave: análise de sensibilidade, modelagem hidrológica, mudanças climáticas.

\section{INTRODUCTION}

In the northeast region of Brazil, classified as a semi-arid region, the construction of reservoirs has been the main decision adopted by water resource managers and by the civil population in order to try to solve the problem of water scarcity in the region over time (Malveira et al., 2012; Toledo et al., 2014). On average, there is one severe drought every decade, which sometimes lasts for many years (Araújo and Bronstert, 2015) - for example, from 2012 to 2015 (Marengo et al., 2017). This reservoir construction policy often occurs without any control or use of technical-scientific knowledge. As a result, a "high-density reservoir network" is produced, with predominantly small- and medium-sized reservoirs, which turns out to be a complex system to manage (Araújo and Piedra, 2009).

Reservoirs have been considered to be the major cause of changes to water flow dynamics in water bodies, thus provoking disruption of hydrological connectivity. Hydrological connectivity in channels or rivers has been evaluated by analysis of water flow continuity in their riverbeds. For this purpose, a minimum flow rate index is used to characterize such hydrological connectivity (Brozovic et al., 2011; Fryirs, 2012; López-Vicente et al., 2013; Garbin et al., 2019). This flow can be measured by fluviometric methods, by injection dilution gauging (Burke, 2009) and also by simulations in hydrological models (Döll et al., 2003; Hanasaki et al., 2010; Malveira et al., 2012; Sun et al., 2015). Lane et al. (2009) highlight that hydrological models have a very important role in hydrological connectivity, as they enable temporal variation and structural connectivity to be checked.

A hydrological model can be defined as a tool of mathematical representation of water flow rate and its interactions with the atmosphere and the terrestrial surface; in other words, representation of hydrological processes that occur in a water basin. This mathematical representation uses a series of parameters, which simulate the characteristics of the environment and modeled physical processes; often, it requires previous calibration and/or sensitivity analysis of these parameters. (Yang et al., 2015; Silva et al., 2015).

Sensitivity analysis enables the identification and definition of the input elements of a model that cause the greatest disturbance in the performance of the output results, that is, how much the output values are affected by changes in input values (Loucks and Van Beek, 2005). Sensitivity analysis helps users to define which elements should be estimated with more 
precision or accuracy, because these are of great relevance for the processes being evaluated. Kruk et al. (2009) noted that knowledge of the sensitivity of the elements of a hydrological model is extremely important to direct field research and to select parameters for future research.

In this context, the general objective of the present study was to perform sensitivity analysis of hydrological connectivity in the water basin of Orós Reservoir by using the ResNet model, designed to simulate the processes involved in fluvial hydrological connectivity in environments with a high density of reservoirs.

\section{MATERIALS AND METHODS}

The study area is the Orós Reservoir Basin, which is nestled at the Alto Jaguaribe Basin (BAJ). The basin is located in the southeast portion of the State of Ceará, in 24 South zone, between the 292000 and $508300 \mathrm{~m}$ abscissas, and the 9180000 and $9409000 \mathrm{~m}$ ordinates, of the rectangular plane UTM for datum WGS - 1984. It has a drainage area of $24211 \mathrm{~km}^{2}$, which corresponds to $97 \%$ of BAJ and $16 \%$ of the State of Ceará, approximately. The climate of the basin, according to Köppen classification, is Bsh, characterized as a steppe's climate, with an average annual temperature of $28^{\circ} \mathrm{C}$. Annual precipitation ranges between 500 and $1000 \mathrm{~mm}$, with an average of $751 \mathrm{~mm}$. It occurs mostly from January to May, with marked irregularity in time and space. Annual potential evaporation in the study area is in the order of $2200 \mathrm{~mm}$. Geologically, it is formed mainly by Precambrian crystalline basement rocks $(81 \%$ of its territory) and, on a smaller scale, by sedimentary deposits (19\%).

The dominant superficial runoff is Hortonian, which generates from 10 to $70 \mathrm{~mm}$ annually. The typical superficial runoff coefficient ranges from 5 to $12 \%$. The main water source of Orós Reservoir Basin is based on the reservoirs spread out in the basin. Toledo et al. (2014), based on satellite images, identified 4717 public and private reservoirs in the basin in 2011 (Figure 1), with a total water storage capacity of $3646 \mathrm{hm}^{3}$. Eighteen reservoirs of this High-density Reservoir Networks (HdRN) are considered to be strategic for water resource management of the basin; they are monitored by the Companhia de Gestão dos Recursos Hídricos do Estado do Ceará (COGERH) (Water Resources Management Company of the State of Ceará).

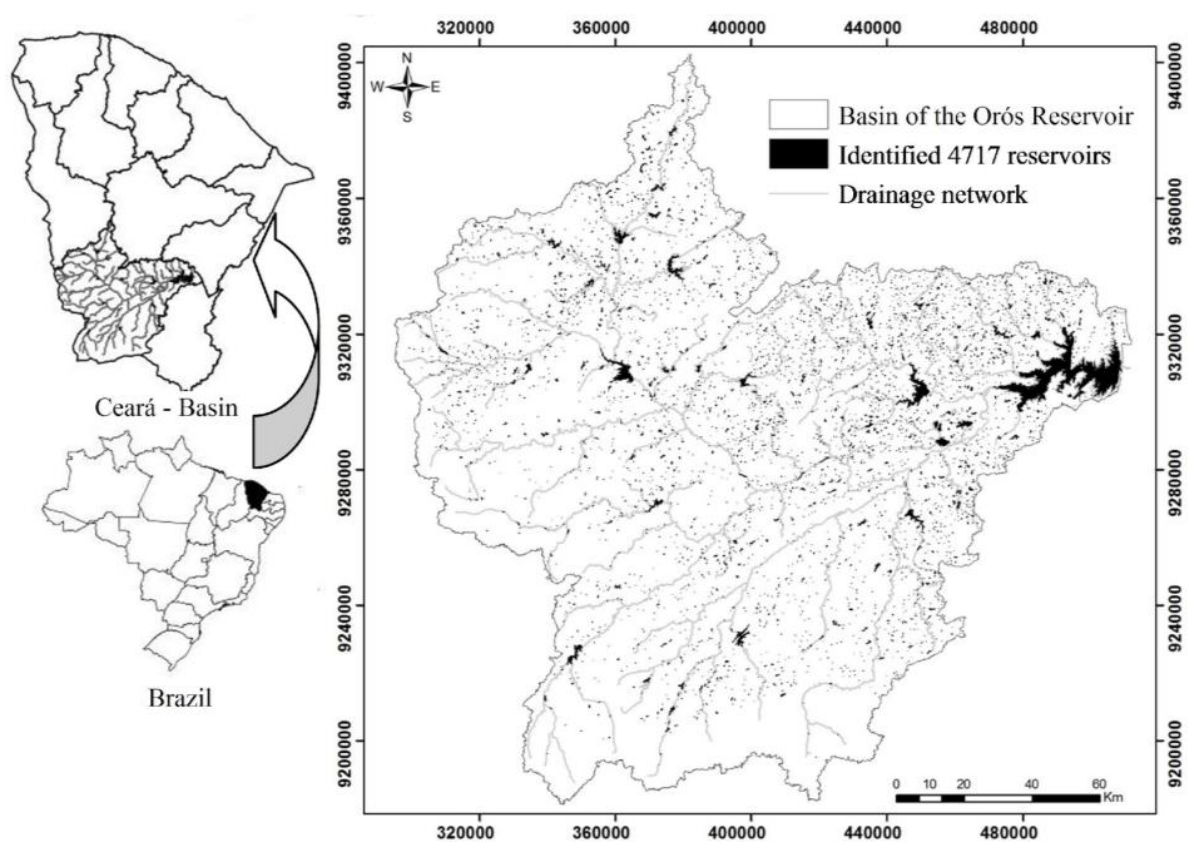

Figure 1. Localization and spatial distribution of the 4717 identified reservoirs, in 2011, in the hydrographic basin of Orós dam (BHAO). 
The hydrological model chosen for the present study was the Reservoir Network Model ResNetM, designed by the study group Grupo de Estudos Hidrosedimentológico do Semiárido - Hidrosed, to simulate the hydrological processes and enable the study of hydrological connectivity in the semiarid environment, while approaching a simplified water balance for each reservoir. The model has the advantage of requiring few input data and low processing time, even when considering the thousands of reservoirs in the basin. This enables intensive studies of its parameters, e.g., sensitivity analysis (Peter et al., 2014).

In the ResNetM model, the dense reservoir network is simulated as a tree, while respecting the location of each reservoir. In this tree, the reservoirs are the vertices or nodes and the connections between them are the branches, with a focus on complex network theory. The reservoirs located at the extremity show only one downstream reservoir and the other "intermediary" reservoirs are spread in the basin; there may be many upstream reservoirs, but only one downstream reservoir. The branches correspond to the draining networks of the basin, which connect the reservoirs. Their direction is determined according to the topography of the terrain, and for this reason, it does not enable the formation of cycles between vertices or reservoirs.

The model begins the interaction between the reservoirs by computing the superficial runoff generated in the sub-basin of each reservoir. Then, the resulting runoff is transferred to the reservoir, where water balance is performed. The flow generation and water balance system begins by the most upstream reservoirs of the network; the flow is transferred in the form of cascades between the sub-basins to the most-downstream reservoir, namely, the Orós Reservoir, considered to be the output vertex of the system, when there is no other downstream reservoir.

The hydrological connectivity of the reservoirs is characterized by the presence of a fluvial flow throughout the whole path of the river between the reservoir and the downstream mouth, whether it is a mouth, a river (affluence), or a new reservoir. In order to possibly acknowledge that the reach was connected, the flow rate could not be lower than a minimum reference flow rate (Speir et al., 2016). A minimum reference flow rate of $1.0 \mathrm{~L} \mathrm{~s}^{-1}$ is adopted, according to Art. 6-o, subsection III, of Resolution 707/2004 from National Water Agency - ANA. Therefore, whenever the flow rate in the upstream reservoir and in the mouth of the reach exceeded $1 \mathrm{~L} \mathrm{~s}^{-1}$, hydrological connectivity of the reach was acknowledged.

Once the hydrological connectivity criteria have been established, the ResNet model can check the Hydrological Connectivity Indicator (HCI) which occurred in the basin. The HCI is estimated by the ratio between the quantity of connected reservoirs (number of hydrologically connected reaches - NHCR) and the product of the total number of reaches in the basin and the number of days of the simulation (Equation 1).

$$
H C I=\frac{N H C R}{T N \times N D}
$$

Where:

NHCR is the total number of hydrologically connected reaches (-); TN is the total number of reaches in the basin (-) and ND is the number of simulated days (days).

The input parameters considered in the sensitivity analysis of the ResNetM model were rainfall $(\mathrm{P})$, potential evaporation $(\mathrm{Ep})$, superficial runoff coefficient $(\mathrm{CR})$, transmission loss coefficient $(\mathrm{K})$, storage capacity of the reservoirs (CA) and reservoir network (Rn). The evaluated output variable was the Hydrological Connectivity Indicator (HCI).

The sensitivity of each parameter was estimated by the Sensitivity Index of Nearing et al. (1990) (Equation 2), which represents the normalized change generated in the output to a

Rev. Ambient. Água vol. 14 n. 4, e2367 - Taubaté 2019 
normalized change in data input. In this way, the furthest from zero IS is, the more sensitive the model is for the input parameter, regardless of whether this value is positive or negative.

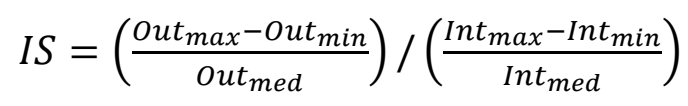

Where:

IS is the sensitivity index of the input parameters; $\mathrm{Int}_{\max }$ and $\mathrm{Int}_{\min }$ are the maximum and minimum values used in the variation of the input parameter; Out ${ }_{\max }$ and $\mathrm{Out}_{\min }$ are the output values for $\mathrm{Int}_{\max }$ and $\mathrm{Int}_{\min }$, respectively; $\mathrm{Int}_{\mathrm{med}}$ and Out $\mathrm{t}_{\mathrm{med}}$ are the averages of input and output values, respectively.

In order to make changes to the values of input parameters, scenarios were created to describe possible alterations that can occur at a particular time in the system. Therefore, each alteration in the input parameter values of the model gave rise to a scenario (Ceteris Paribus principle), which was simulated with the same time period of the current system of the basin (1991 to 2011). These alterations have the following characteristics, the reference rainfall height was reduced by $5,10,15,20,25,30,35,40,45$ and $50 \%$, and also increased by 5, 10, 15 and $20 \%$. These values were based on studies which evaluated the effects of climate change in rainfall until 2100 in Brazilian Semiarid (Krol et al., 2011). The potential evaporation of the scenarios were set up to increase the Ep reference value by 1, 5, 7, 10 and 15\%; these values were based on Krol et al. (2011). Although there was a lack of scientific evidence for a possible decrease of Ep in the region, a reduction in Ep values was simulated in the same proportions of the increase $(-1,-5,-7,-10$ and $-15 \%)$, thus generating another 10 scenarios.

- Runoff Coefficient (RC): in the variation of $\mathrm{RC}$, the scenarios were arranged by multiplying the specific $\mathrm{RC}$ reference values from the 18 sub-basins of the strategic reservoirs by the factors of $0.10 ; 0.25 ; 0.50 ; 0.75 ; 1.25 ; 1.50 ; 1.75$ and 2.00 , which represent the possible changes in the landscape from soil use and occupation.

- Transmission Loss Coefficient $(\mathrm{k})$ : changes in the reference value of transmission loss were made multiplying the $\mathrm{K}$ reference value by the factors of $0.10,0.25,0.50,0.75,1.25$, $1.50,1.75$ and 2.00 , in order to simulate a possible variation in water abstraction from rivers, as a result of anthropic factors and/or predicted climate changes for the region in this millennium (Krol et al., 2011);

- Reservoir storage capacity (Ca): simulated by varying $+5,+25,+50,+75,+100,-5,-25$, -50 and $-70 \%$. As a result, the strategic reservoirs did not suffer variations in their storage capacity;

- Reservoir Network (Rn): sensitivity of hydrological connectivity to the presence of thousands of reservoirs was calculated by modifying the reservoir network topology. The reservoirs from Class $1\left(<0.1 \mathrm{hm}^{3}\right)$, Class $2\left(0.1-1 \mathrm{hm}^{3}\right)$ and Class $3\left(1-3 \mathrm{hm}^{3}\right)$ were gradually excluded from the network, and three "artificial" networks were generated, namely, Rn1, Rn12 and Rn123, respectively.

To evaluate the behavior of the scenarios and determine the effect of the dense reservoir network on hydrological connectivity, investigations were made regarding the ratio between the HCI of the scenarios and the total volume stored in the basin, as well as the volume stored in the Orós Reservoir.

\section{RESULTS AND DISCUSSION}

Sensitivity analysis (Sensitivity Index - SI, Table 1) of the hydrological connectivity demonstrated high sensitivity $(\mathrm{SI}>0.80)$ to variation in the reservoir network $(\mathrm{SI}=1.07)$ and 
to runoff coefficient $(\mathrm{SI}=0.84$ ) and moderate sensitivity ( $\mathrm{SI}=0.40$ to 0.80 ) to variation in storage capacity of non-strategic reservoirs $(\mathrm{SI}=0.45)$ and rainfall alteration $(\mathrm{SI}=0.46)$. However, hydrological connectivity in Orós Reservoir Basin has low sensitivity to potential evaporation $(\mathrm{SI}=0.19)$ in the reservoirs and even lower to transmission loss in rivers and streams $(\mathrm{SI}=0.003)$.

Table 1. Sensitivity Index (SI) of hydrological connectivity for the main input parameters of ResNetM model.

\begin{tabular}{lcccc}
\hline \multirow{2}{*}{ Input parameter } & \multirow{2}{*}{ Reference input value } & \multicolumn{2}{c}{ Interval of values } & \\
\cline { 3 - 4 } & & Input & ICH $(\%)$ & \\
\hline Rainfall $(\mathrm{mm})$ & 1.88 & $0.94-1.97$ & $4.94-7.25$ & 0.46 \\
Potential evaporation $\left(\mathrm{mm}\right.$ month $\left.^{-1}\right)$ & 207.8 & $176.6-209.9$ & $7.03-6.57$ & 0.19 \\
Runoff coefficient $(-)$ & 0.03 & $0.003-0.06$ & $2.17-8.20$ & 0.84 \\
Transmission loss $\left(\mathrm{km}^{-1}\right)$ & 0.027 & $0-0.054$ & $6.79-6.76$ & 0.01 \\
Reservoir storage capacity $\left(\mathrm{hm}^{3}\right)$ & 0.73 & $0.18-1.46$ & $8.69-5.48$ & 0.45 \\
Reservoir network $(-)$ & 4717 & $53-650$ & $4.00-5.84$ & 1.07 \\
\hline
\end{tabular}

The variations of parameters $\mathrm{k}$ and $\mathrm{P}$ resulted in alteration of HCI in a "stable" rhythm, resulting in a linear tendency (Figure 2), in which a low slope refers to the axis of abscissas. The low sensitivity of hydrological connectivity to evaporation (Ep) can be explained by the period in which the highest HCI values occurred, in the rainy season of the basin. Consequently, in the rainy season, the atmospheric abstractions decrease and thereby volumetric losses in the reservoirs are small, hence not enough to significantly affect the HCI of the basin. In the case of transmission loss (k), the low sensitivity of hydrological connectivity is due to the short extension of the reaches. The thousands of reservoirs present in the basin break the draining network in short reaches (average size of $1.89 \mathrm{~km}$ ), and consequently, water losses in these reaches become small: on average $5.1 \%$ of fluvial flow rate.

Initially, it was thought that amongst the "natural" elements, rainfall would promote the largest variations in the HCI of Orós Reservoir Basin. However, this moderate influence of rainfall over hydrological connectivity can be explained by the type of modification performed in rainfall. Rainfall variations altered the height captured directly by the reservoirs and the runoff volume in sub-basins, yet it did not influence the number of days with rainfall, and it modified the runoff coefficient to an even lesser degree. This coefficient varies according to the presence of previous rainfall, regardless of height.

It is believed that high sensitivity of hydrological connectivity to variation in runoff coefficient (CR) is linked to the process of (Hortonian) runoff generation in the region. In the process of Hortonian runoff, rainfall intensity must surpass infiltration capacity for runoff to occur. In long hillslopes, the runoff generated upstream can re-infiltrate (Medeiros et al., 2010; Safeeq and Fares, 2012). It has already been seen in other studies that the average annual rainfall below the average indicates conditions of low hydrological connectivity when compared to the average and temporarily well distributed rain years (Fryirs, 2012). Since connectivity is understood as the transfer of matter between two distinct topographical points, the identification of the connectivity patterns in a river basin allows the investigation of the cumulative impacts of small reservoirs of water resources (Lopes and Pinheiro, 2015).

In this way, soil infiltration capacity, represented inversely by the runoff coefficient (CR), becomes determinant in the process of superficial runoff re-infiltration, thus influencing directly the flow that reaches the draining network and, consequently, the hydrological connectivity of the basin. For example, when the CR parameter was increased by $50 \%$, the possibility of superficial runoff re-infiltration decreases. The repercussions of such lower re-

Rev. Ambient. Água vol. 14 n. 4, e2367 - Taubaté 2019 
infiltration was that the runoff volume which reached the draining network increased and, consequently, the HCI value was $13 \%$ higher than the reference HCI. When the CR was reduced in the same magnitude $(-50 \%)$, the probability for the superficial runoff to re-infiltrate increased, thus reducing the runoff volume, and the HCI decreased by $29 \%$, when compared with the reference value. That can be influenced by several factors; a study conducted by Rodrigues et al. (2013), observed changes in surface runoff as a consequence of the partial removal of vegetation by thinning; while in other events the average leaflet depth was higher in the preserved micro basin. Those results revealed that the practice of caatinga thinning presented modifications, presented values of drained slides inferior to those of the preserved micro basin; it was verified, however, that the maximum discharges in the thinned micro basin were superior to those of the preserved basin.
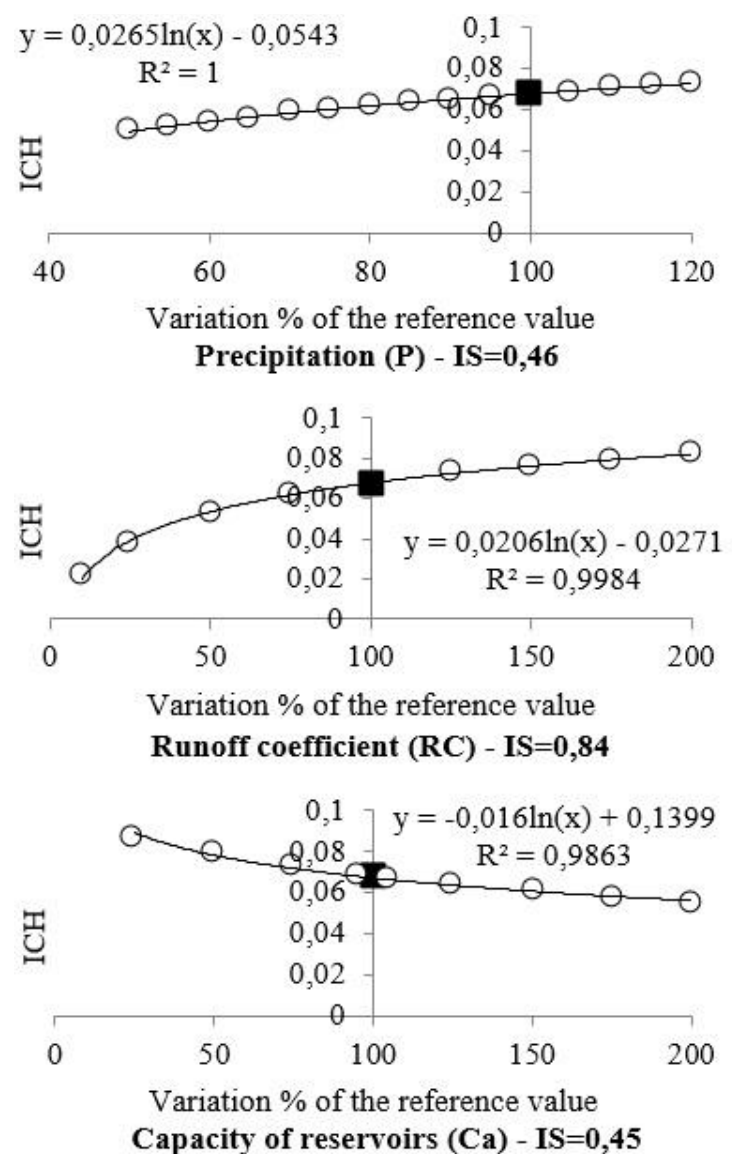
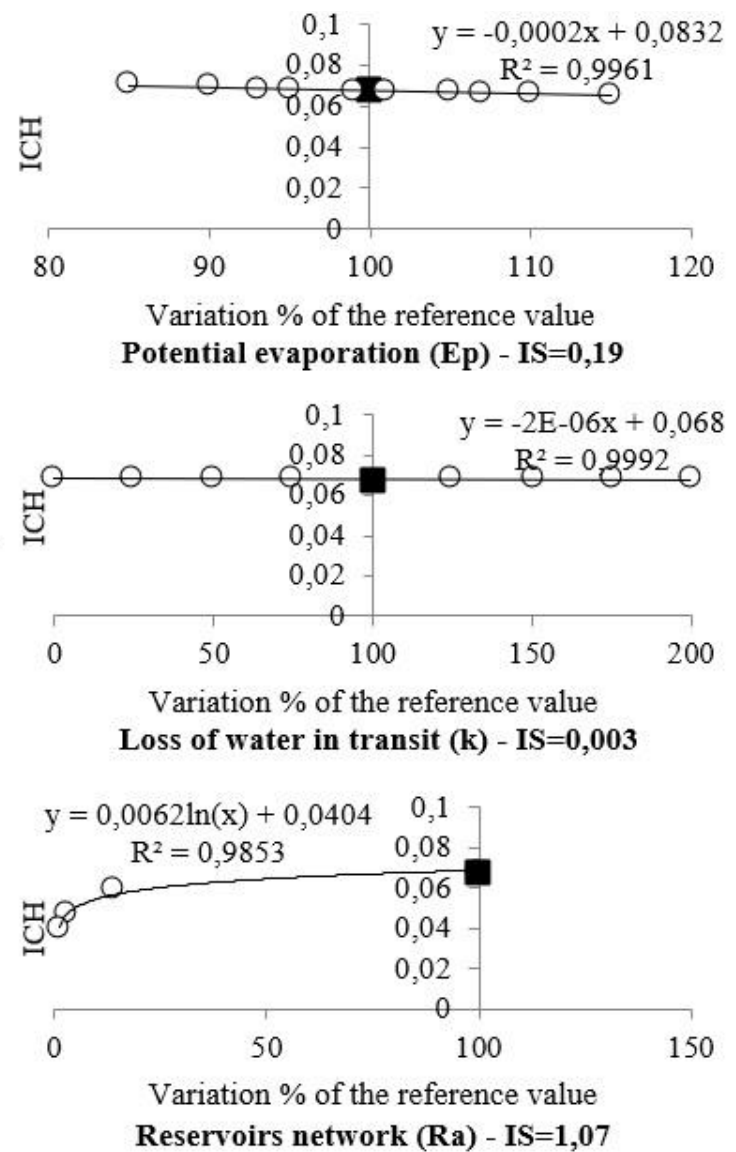

Reservoirs network (Ra) - IS $=1,07$

Figure 2. Values of hydrological connectivity index (ICH) obtained in BHAO, as a function of input parameters variation from ResNetM model for the period of 2001 to 2011.

In the case of variation in the reservoir network topology, the high sensitivity of hydrological connectivity confirms that anthropic intervention in the environment has been significantly interfering in the fluvial flow regime of a basin. As simulated, after removal of thousands of small- and medium-sized reservoirs of the reservoir-dense network of Orós Reservoir Basin, the HCI was significantly reduced (41\% compared with the reference HCI). This indicates that the small- and medium reservoirs, even in the presence of minor fluvial floods, are capable of producing an effluent flow (sangria) enough to overcome the transmission losses (small reaches) and connect with the downstream reservoir. However, without the thousands of reservoirs, the minor floods normally are not capable of generating hydrological connectivity between the reservoirs.

The prominent roles of rainfall, reservoir network topology and superficial runoff properties over hydrological connectivity have been addressed in other hydrological studies as 
well as in ecological ones (Callow and Smettem, 2009; Hall et al., 2012; Long and Pavelsky, 2013). Bracken and Croke (2007) found that, in the scale of a hydrographic basin in semiarid areas, hydrological connectivity usually requires high intensity rainfall uniformly distributed throughout the basin, while slope connectivity can be initiated by short-lasting rainfall, or by less intense events. However, the authors have warned that each hydrographic basin has a spatial base pattern in terms of hydrological connectivity, which depends, primarily, on the runoff generating areas and on the rainfall-runoff relation.

In regard of the influence of the dense-reservoir network topology, Jackson and Pringle (2010) argue that the thousands of small reservoirs alter the hydrological connectivity of terrestrial landscape in innumerable ways. They hold from 81 to $98 \%$ of sediments and nutrients that are affluent to these reservoirs; they block or prevent the longitudinal movements of aquatic organisms; they transform lotic habitats into lentic habitats; and they alter the temporal series of downstream flows.

In regard of superficial runoff, Bracken and Croke (2007) point out that, in semiarid and arid environments, hydrological connectivity occurs differently compared with humid and temperate areas because Hortonian is the most common type of runoff. As a general rule, hydrological connectivity in semiarid and arid environments is harder to achieve and occurs less frequently than in temperate and humid areas. This difference in hydrological connectivity between dry and temperate/humid areas is due to many factors, for example, precedent conditions of soil humidity.

A good correlation $\left(\mathrm{R}^{2}=0.74\right)$ was found after an analysis of the relation between the volume of water stored in the basin and the HCI (Figure 3). One can notice that, when modifying the HCI, the volume stored in the basin follows the same tendency; that is, when the HCI decreased, the volume stored in the basin decreased as well; when the HCI increased, the stored volume increased. However, when the HCI is lower than 5.5\%, the volume stored in the basin reduces more rapidly. This shows that the volume stored in Orós Reservoir Basin is more sensitive ( $\mathrm{SI}=1.83$ ) to a reduction of the reference $\mathrm{HCI}$ than to an increase ( $\mathrm{SI}=0.26)$. The results confirmed that hydrological connectivity can be a good indicator of water availability in semiarid hydrographic basins.

An evaluation of the influence of HCI variation over the behavior of the volume stored in Orós Reservoir, showed that the influence of natural elements is different from the influence of anthropic elements (Figure $3 \mathrm{~A}$ and B). The reduction in HCI caused by one of the natural elements being analyzed - for example, superficial runoff $(\mathrm{CR})$ or rainfall $(\mathrm{P})$ - would cause a significant reduction in the volume stored in Orós reservoir $(\mathrm{SI}=1.45)$. In other words, there would be lower water availability in the reservoir.

The reduction or increase of HCI caused by changes to one of the anthropic elements being analyzed, that is, the increase or reduction in storage capacity of the reservoirs or alteration in the reservoir network topology, did not entail expressive changes in the stored volume of Orós Reservoir, yielding a sensitivity index (SI) of only 0.21 . For example, by doubling the storage capacity of non-strategic reservoirs, the HCI decreased by $20 \%(\mathrm{HCI}=5.5 \%)$, and the stored volume in Orós Reservoir would be reduced by only $1.3 \%$, when compared with the reference volume $\left(1520 \mathrm{hm}^{3}\right)$, thus resulting in a sensitivity index (SI) of only 0.06 .

Thereby, if the storage capacity of small and medium reservoirs spread out in Orós Reservoir Basin increased by $100 \%$, the volume retained by them would not significantly affect the volume stored in Orós Reservoir. Or yet, if the 4664 reservoirs were removed, thus forming, the reservoir network denominated Rn123, the HCI would fall to 4\% (59\% less). However, the stored volume in Orós Reservoir would increase to $280 \mathrm{hm}^{3}$. This increase is considered to be very small (IS=0.09), because the direct catchment area of Orós Reservoir would increase from $996 \mathrm{~km}^{2}$ to $12340 \mathrm{~km}^{2}$ after the removal of these thousands of reservoirs (Figure 4).

Rev. Ambient. Água vol. 14 n. 4, e2367 - Taubaté 2019 

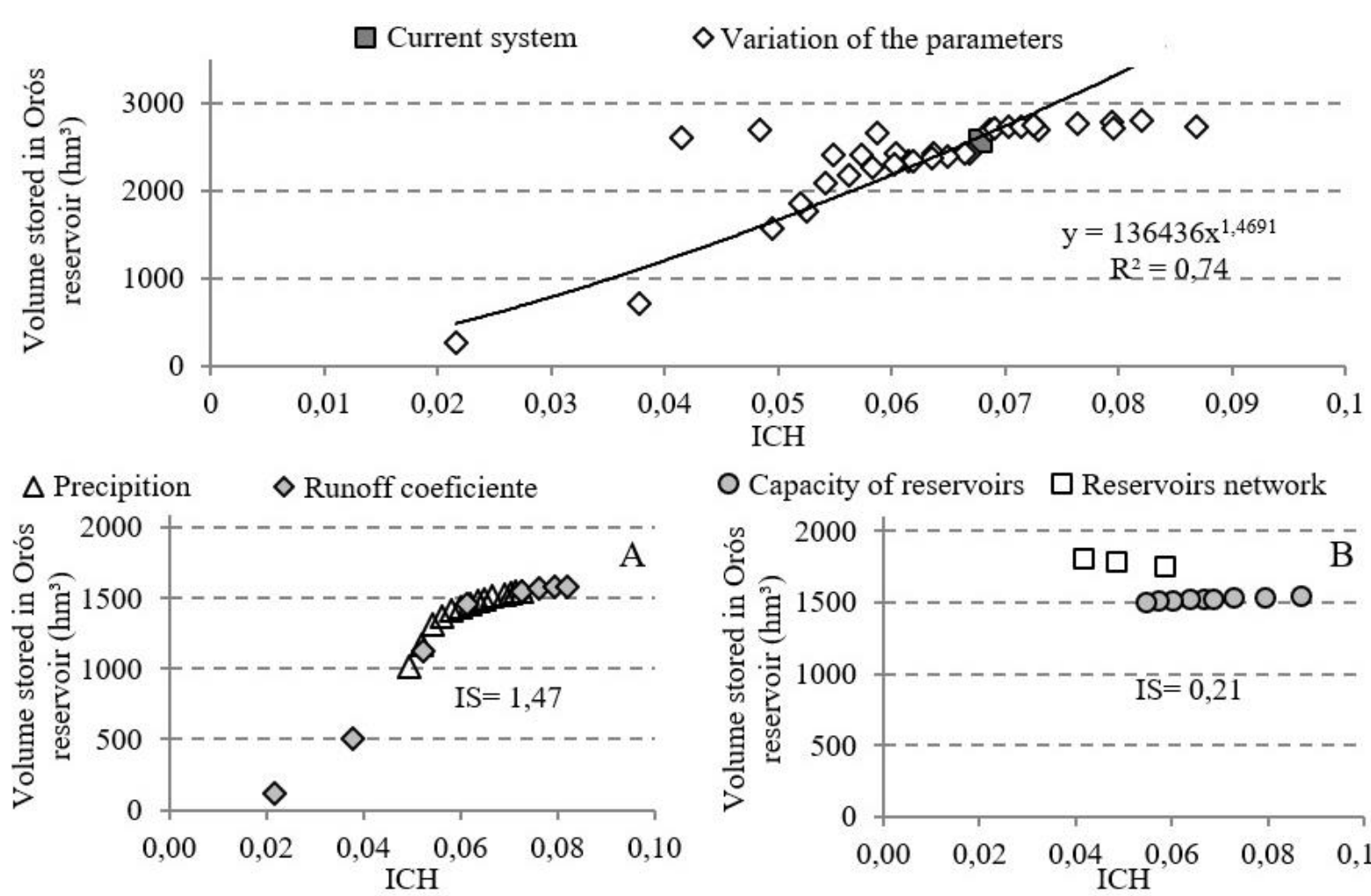

O Capacity of reservoirs $\square$ Reservoirs network

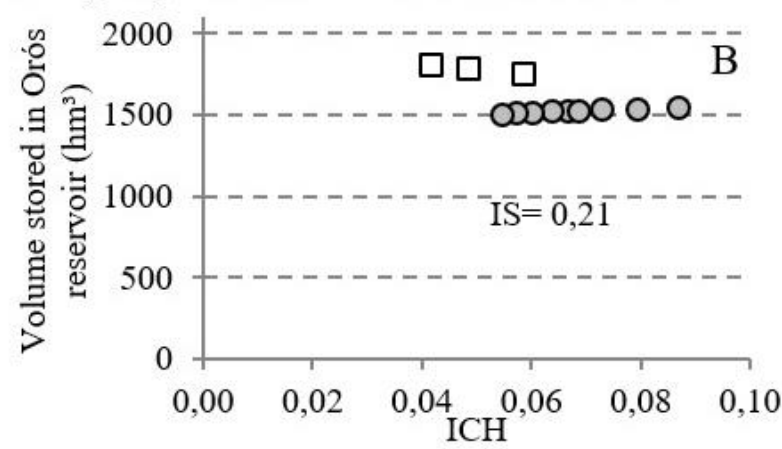

Figure 3. Highlighted: Relation between the Hydrological Connectivity Index (ICH) with the stored volume in the hydrographic basin of Orós dam (BHAO), according to the simulation of the scenarios in the ResNetM model, for the period of 1991 to 2011. In figures A and B: Relation between the hydrological connectivity index (ICH) and the volume stored in Orós dam, according to the variation of the natural (A) and anthropic (B) elements of major relevance for the hydrological connectivity of BHAO.

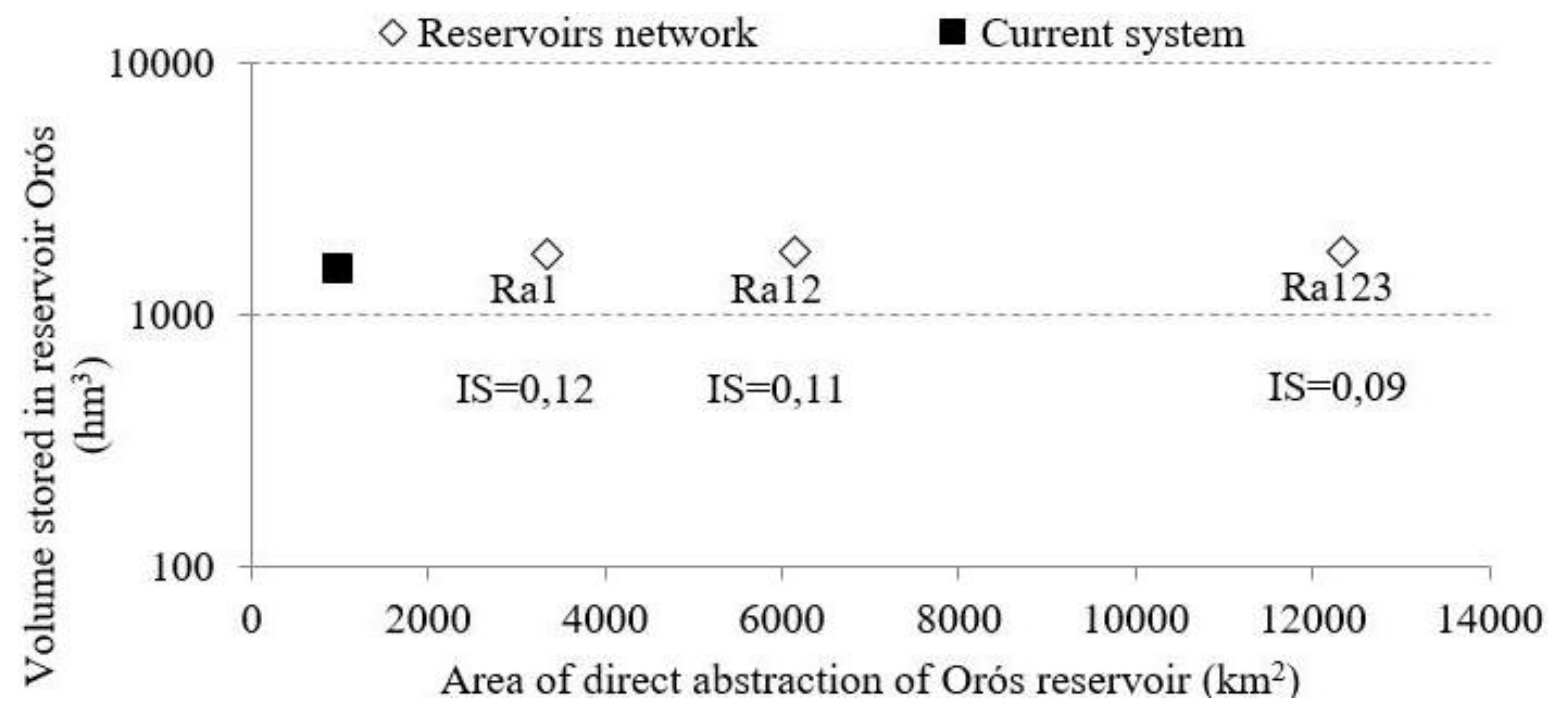

Figure 4. Relation between the direct catchment area and the average stored volume of Orós dam, obtained in the simulation of the current BHAO System and of the reservoir network variation (Ra).

The low influence of the HCI, calculated by changing the reservoir dense network topology over the stored volume in Orós Reservoir, was a surprising result. However, this is evidence that the volume of Orós Reservoir has low sensitivity to the presence or absence of the thousands of small- and medium-sized reservoirs built upstream over the years $(\mathrm{SI}=0.12)$. Thus, one can affirm that the spatial distribution of water performed by the high-density 
reservoir network (HdRN) of Orós Reservoir Basin has not been causing any significantly negative impact over the stored volume and, consequently, over the water availability of Orós Reservoir, if the superficial runoff and rainfall conditions inside the basin do not decrease.

The expansion of water-resource development has been a threat to the natural flow regime and the ecological integrity of rivers and streams in the Brazilian semi-arid region. Efforts to manage and conserve the natural flow regime of these systems is hampered by limited scientific information on processes that lead to high natural variability in the water flow regime (Maltchik and; Medeiros, 2006; Santos et al., 2017). Although there is a consensus that the main impacts of reservoirs are a decrease in river discharges, peak flows due to water abstraction from reservoirs and water loss, impacts on low river flow may vary from basin to basin due to many types of reservoirs and their different uses, a factor that makes it difficult to anticipate the estimation of hydrological connectivity even using several types of indicators (Habets et al., 2018). However, there is still a lack of data on the flows of these waterways, which increases the need to apply hydrological models to this estimation; studies being developed in this estimation are important to carry out this management (Maltchik and Medeiros, 2006; Santos et al., 2017).

\section{CONCLUSIONS}

Based on the analyses performed in the present study, it can be concluded that the runoff coefficient and the reservoir network (change in the reservoir number of the network), were the parameters evaluated with the highest sensitivity of hydrological connectivity. Thus, the alteration of the landscape by man provides significant changes in river navigation between reservoirs in the basin. In the case of the topology of the reservoir network, the presence of thousands of small- and medium reservoirs is not broken, keeping the reservoir network connected even during small river floods.

The reduction of the reservoir network also provides a reduction in the hydrological connectivity of the basin; it also provides a reduction of spatial availability of water inside the basin, besides not significantly altering the inflow to the strategic reservoir of the basin, the Orós Reservoir, considered the main discharging body of the basin in this work.

\section{REFERENCES}

ARAÚJO, J. C.; BRONSTERT, A. A method to assess hydrological drought in semi-arid environments and its application to the Jaguaribe River basin, Brazil. Water $\begin{array}{lllllll}\text { International, } & \text { v. } & 41, & \text { n. } & 2, & \text { p. } & 213-230,\end{array}$ https://dx.doi.org/10.1080/02508060.2015.1113077

ARAÚJO, J. C.; PIEDRA, J. I. G. Comparative hydrology: analysis of a semiarid and a humid tropical watershed. Hydrological Processes, v. 23, p. 1169-1178, 2009. https://doi.org/10.1002/hyp.7232

BRACKEN, L.J.; CROKE, J. The concept of hydrological connectivity and its contribution to understanding runoff-dominated geomorphic systems. Hydrological Processes, v. 1763, p. 1749-1763, 2007. https://dx.doi.org/10.1002/hyp.6313

BROZOVIC, N.; HAN, J.; SPEIR, C. Spatial Dynamic Optimization of Groundwater Use with Ecological Standards for Instream Flow. In: AMERICAN GEOPHYSICAL UNION, Fall Meeting, 2011. Abstract [...] Washington: AGU, 2011. https://dx.doi.org/10.1142/S2382624X16500132 
BURKE A.R. A comparison of soil moisture and hillslope-stream connectivity between aspen and conifer-dominated hillslopes of a first order catchment in northern Utah. 2009. 125p. Thesis - Utah State University, Logan, UT. 2009.

CALLOW, J. N.; SMETTEM, K.R.J. The effect of farm dams and constructed banks on hydrologic connectivity and runoff estimation in agricultural landscapes. Environmental $\begin{array}{lllllll}\text { Modelling and Software, } & \text { v. 24, p. } & \text { 959-968, }\end{array}$ https://dx.doi.org/10.1016/j.envsoft.2009.02.003

DÖLL, P.; KASPAR, F.; LEHNER, B. A global hydrological model for deriving water availability indicators: model tuning and validation. Journal of Hydrology, v. 270, n. 2003, p. 105-134, 2003. https://dx.doi.org/10.1016/S0022-1694(02)00283-4

FRYIRS, K. (Dis)Connectivity in catchment sediment cascades: a fresh look at the sediment delivery problem. Earth Surface Processes and Landforms, v.38, n.1, p. 30-46, 2012. https://dx.doi.org/10.1002/esp.3242

GARBIN, S.; CELEGON, E. A.; FANTON, P.; BOTTER, G. Hydrological controls on river network connectivity. Royal Society Open Science, v. 6, n. 2, p. 1-20, 2019. https://dx.doi.org/10.1098/rsos.181428

HABETS, F.; MOLÉNAT, J.; CARLUER, N.; DOUEZ, O.; LEENHARDT, D. The cumulative impacts of small reservoirs on hydrology: A review. Science of the Total Environment, v. 643, p. 850-867, 2018. https://dx.doi.org/10.1016/j.scitotenv.2018.06.188

HALL, C. J.; JORDAAN, A.; FRISK, M. G. The historic influence of dams on diadromous fish habitat with a focus on river herring and hydrologic longitudinal connectivity. Landscape Ecology, v. 26, p. 95-107, 2011. https://dx.doi.org/10.1007/s10980-010-9539-1

HANASAKI, N.; INUZUKA, T.; KANAE, S.; TAIKAN OKI, T. An estimation of global virtual water flow and sources of water withdrawal for major crops and livestock products using a global hydrological model. Journal of Hydrology, v. 384, n. 3-4, p. 232-244, 2010. https://doi.org/10.1016/j.jhydrol.2009.09.028

JACKSON, C. R.; PRINGLE, C. M. Ecological Benefits of Reduced Hydrologic Connectivity in Intensively Developed Landscapes. BioScience, v. 60 n. 1, p.37-46, 2010. https://dx.doi.org/10.1525/bio.2010.60.1.8

KROL M. S.; VRIES, M. J.; VAN OEL, P. R.; ARAÚJO, J. C. Sustainability of Small Reservoirs and Large Scale Water Availability Under Current Conditions and Climate Change. Water Resour Manage, v. 25, p. 3017-3026, 2011. https://dx.doi.org/10.1007/s11269-011-9787-0

KRUK, N. S.; VENDRAME, I. F.; CHAN, C. S.; LADEIRA, F. S. B. Sensitivity Analysis of the Distributed Hydrological Model DHSVM to Vegetation Parameters. Revista

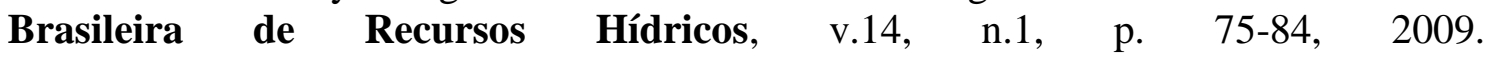
https://dx.doi.org/10.21168/rbrh.v14n1.p75-84

LANE, S. N.; REANEY, S. M.; HEATHWAITE, A. L. Representation of landscape hydrological connectivity using a topographically driven surface flow index. Water Resources Research, v. 45, n. 8, 2009. https://dx.doi.org/10.1029/2008WR007336

LONG, C. M.; PAVELSKY, T. M. Remote sensing of suspended sediment concentration and hydrologic connectivity in a complex wetland environment. Remote Sensing of Environment, n. 129, p. 197-209, 2013. https://dx.doi.org/10.1016/j.rse.2012.10.019 
LOPES, J. W. B.; PINHEIRO, E. A. R. Análise temporal da conectividade e da capacidade de transporte potencial de sedimentos em meso-bacia semiárida, CE, Brasil. Revista Agro@Mbiente on-Line, v. 7, n. 2, p. 136, 2015.

LÓPEZ-VICENTE, M.; POESEN, J.; NAVAS, A.; GASPAR, L. Predicting runoff and sediment connectivity and soil erosion by water for different land use scenarios in the $\begin{array}{lllll}\text { Spanish Pre-Pyrenees. } & \text { Catena, } & \end{array}$ https://dx.doi.org/10.1016/j.catena.2011.01.001

LOUCKS, D. P.; VAN BEEK, E. Model Sensitivity and Uncertainty Analysis. In: LOUCKS, D. P.; VAN BEEK, E. Water Resources Systems Planning and Management. Paris, 2005. p. 255-290.

MALVEIRA, V. T. C.; ARAÚJO, J. C.; GÜNTNER, A. Hydrological Impact of a High-Density Reservoir Network in the Semiarid North-Eastern Brazil. Journal of Hydrologic Engineering, v. 17, n. 1, p. 109-117, 2012. https://dx.doi.org/10.1061/(ASCE)HE.19435584.0000404

MALTCHIK, L.; MEDEIROS, E.S.F Conservation importance of semi-arid streams in northeastern Brazil: implications of hydrological disturbance and species diversity. Aquatic Conservation: Marine and Freshwater Ecosystems, v. 19, n. January, p. 127-133, 2009.

MARENGO, J. A.; TORRES, R. R.; ALVES, L. M. Drought in Northeast Brazil - past, present, and future. Theoretical and Applied Climatology, v. 129, n. 3-4, p. 1189-1200, 2017. https://dx.doi.org/10.1007/s00704-016-1840-8

MEDEIROS, P. H. A.; GÜNTNER, A.; FRANCKE, T.; MAMEDE, G.; de ARAÚJO, J. C. Modelling spatio-temporal patterns of sediment yield and connectivity at a semi-arid catchment with WASA-SED model. Hydrological Sciences Journal, v. 55, n. 4, p. 636648, 2010. https://dx.doi.org/10.1080/02626661003780409

NEARING, M. A.; DEER-ASCOUGH, L.; LAFLEN, J. M. Sensitivity analysis of the WEPP hillslope profile erosion model. TASAE, v. 3, n. 33, p. 839-849, 1990.

PETER, S. J.; ARAÚJO, J. C.; ARAÚJO, N. A. M.; HERRMANN, H. J. Flood avalanches in a semiarid basin with a dense reservoir network. Journal of Hydrology, n. 512, p 408420, 2014. https://dx.doi.org/10.1002/hyp.7232

RODRIGUES, J. O.; ANDRADE, E. M. DE; MENDONÇA, L. A. R.; et al. Respostas hidrológicas em pequenas bacias na região semiárida em função do uso do solo. Revista Brasileira de Engenharia Agrícola e Ambiental, v. 17, n. 3, p. 312-318, 2013.

SAFEEQ, M.; FARES, A. Hydrologic effect of groundwater development in a small mountainous tropical watershed. Journal of Hydrology, v. 428-429, p. 51-67, 2012. https://dx.doi.org/10.1016/j.jhydrol.2012.01.023

SANTOS, J. C. N. DOS; ANDRADE, E. M. DE; MEDEIROS, P. H. A.; PALÁCIO, H. A. DE Q.; NETO, J. R. DE A. Sediment delivery ratio in a small semi-arid watershed under conditions of low connectivity. Revista Ciencia Agronomica, v. 48, n. 1, p. 49-58, 2017.

SILVA, M. G.; AGUIAR NETTO, A. O.; NEVES, R. J. J.; VASCO, A. N.; ALMEIDA, C.; FACCIOLI, G. G. Sensitivity Analysis and Calibration of Hydrological Modeling of the Watershed Northeast Brazil. Journal of Environmental Protection, v. 6, p. 837-850, 2015. https://dx.doi.org/10.4236/jep.2015.68076 
SPEIR, C.; HAN, J.; BROZOVIC, N. Spatial Dynamic Optimization of Groundwater Use with Ecological Standards for Instream Flow. Water Economics and Policy, v. 02, n. 03, 2016. https://dx.doi.org/10.1142/S2382624X16500132

SUN, W; ISHIDAIRA, H.; BASTOLA, S.; YUA, J. Estimating daily time series of streamflow using hydrological model calibrated based on satellite observations of river water surface width: Toward real world applications. Environmental Research, v.139, p. 36-45, 2015. https://dx.doi.org/10.1016/j.envres.2015.01.002

TOLEDO, C. E.; ARAÚJO, J. C.; ALMEIDA, C. L. The use of remote-sensing techniques to monitor dense reservoir networks in the Brazilian semiarid region. International Journal of Remote Sensing, v. 35, n. 10, p. 3683 - 3699, 2014. https://dx.doi.org/10.1080/01431161.2014.915593

YANG, J. C.; WANG, Z. H.; CHEN, F.; MIAO, S. G.; TEWARI, M.; VOOGT, J. A.; MYINT, S. Enhancing Hydrologic Modelling in the Coupled Weather Research and ForecastingUrban Modelling System. Boundary-Layer Meteorology, v. 155, n. 2, p. 87-109, 2015. https://dx.doi.org/10.1007/s10546-014-9991-6 


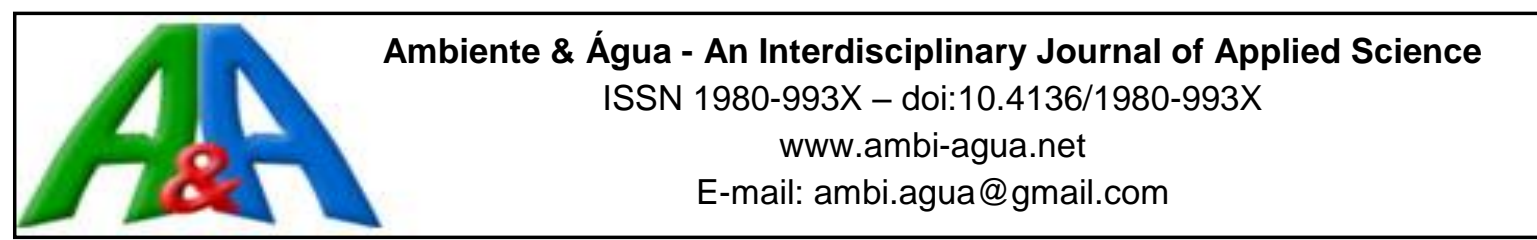

\title{
Selection of variables in the definition of a water quality index for the Brazilian Federal District
}

\author{
ARTICLES doi:10.4136/ambi-agua.2385
}

Received: 25 Feb. 2019; Accepted: 10 Jun. 2019

\author{
Ana Luiza Litz Passos ${ }^{1}$; ; Daphne Heloisa de Freitas Muniz ${ }^{\text {(D); }}$ \\ Leandro Pin Rangel ${ }^{3}$; ; Eduardo Cyrino Oliveira-Filho ${ }^{*}$ (D) \\ ${ }^{1}$ Universidade de Brasília (UnB), Brasília, DF, Brasil \\ Programa de Pós-graduação em Ciências Ambientais (UnB/FUP). E-mail: analuizalitz@ gmail.com \\ ${ }^{2}$ Embrapa Cerrados, Planaltina, DF, Brasil \\ Laboratório de Química Analítica de Água. E-mail: daphne.muniz@embrapa.br \\ ${ }^{3}$ Centro Universitário de Brasília (UniCEUB), Brasília, DF, Brasil \\ Faculdade de Ciências da Educação e Saúde (FACES). E-mail: leandro.rangel5@ gmail.com \\ ${ }^{4}$ Embrapa Cerrados, Planaltina, DF, Brasil \\ Centro de Pesquisa Agropecuária dos Cerrados. E-mail: eduardo.cyrino@embrapa.br \\ "Corresponding author
}

\begin{abstract}
Water Quality Indices (WQIs) are based on a small number of variables that establish categories for water quality. This method presents some problems with the evaluations, since WQIs do not consider the multiple uses of the water or differences in regional characteristics. The present study proposes a regional and more appropriate variable group for the definition of a Water Quality Index for the Brazilian Federal District, based on water quality monitoring of surface waters in the region. The monitoring was carried out monthly between August 2016 and July 2017, at three points on the Jardim River, Sobradinho Stream and Sarandi Stream, where 21 variables were evaluated. Among physical-chemical and microbiological analyses, the regional characteristics of these water bodies were noted, as well as their differences, and the main anthropogenic interferences that generate changes in water quality. In the urban area, the disposal of treated sewage from the wastewater treatment plant of Sobradinho was highlighted as the main anthropic interference, and agricultural activities stood out in the rural region of the study area. The impacts in the urbanized area were of greater weight. Thus, based on the results of the Principal Component Analysis (PCA), two groups of variables were selected, one representative of urban areas and the other of rural areas, to compose two probable water quality indices (WQIs) for the Federal District.
\end{abstract}

Keywords: Brazilian Federal District, regional variables, surface water, WQI.

\section{Seleção de variáveis na definição de um índice de qualidade de água para o Distrito Federal}

\section{RESUMO}

Os Índices de Qualidade da Água - IQAs, baseiam-se em um pequeno número de variáveis que estabelecem categorias para a qualidade da água. Esse método apresenta alguns problemas quanto às avaliações, pois os IQAs não consideram os usos múltiplos da água, bem como as diferenças nas características regionais. O presente estudo tem como objetivo propor um grupo

This is an Open Access article distributed under the terms of the Creative Commons
Attribution License, which permits unrestricted use, distribution, and reproduction in any
medium, provided the original work is properly cited.


de variáveis regional e mais apropriado para a definição de um Índice de Qualidade de Água para o Distrito Federal, baseado no monitoramento da qualidade de água de rios da região. Foi realizado monitoramento mensal entre agosto de 2016 a julho de 2017, em três pontos do Ribeirão Sobradinho, do Córrego Sarandi e do Rio Jardim, onde foram avaliadas 21 variáveis. Dentre análises físico-químicas e microbiológicas, foram observadas as características regionais desses corpos hídricos, bem como suas diferenças, e as principais interferências antrópicas que geram alteração na qualidade da água. Destacou-se na área urbana como principal interferência antrópica o descarte do esgoto tratado da estação de tratamento de esgoto de Sobradinho, e as atividades agropecuárias na região rural da área de estudo. Os impactos da área urbanizada foram de maior proporção. Dessa forma, baseado nos resultados da Análise de Componentes Principais - ACP, foram selecionados dois grupos de variáveis, sendo um representativo para a áreas urbanas e outro para áreas rurais, para compor dois prováveis índices de qualidade da água para o Distrito Federal.

Palavras-chave: água superficial, Distrito Federal Brasileiro, IQA, variáveis regionalizadas.

\section{INTRODUCTION}

Knowledge of the environmental characteristics of a given region is a basic tool for its sustainable development. In this context, studies on natural resources are included, and water appears to be one of the most important (Saad et al., 2007). In conflicts over water use, there is a pressing need for the establishment of tools capable of responding with agility and confidence to questions related to water use in Brazil. The monitoring and evaluation of surface water quality are key factors for the appropriate management of water resources (ANA, 2018). Monitoring water quality should be seen as a means of verifying its potability for human consumption. Several economic activities carried out in Brazil, such as agribusiness, can generate negative socio-environmental impacts for water resources (Medeiros et al., 2016).

Another important anthropic activity that generates environmental impact is the disposal of waste in water systems, as well as the use and occupation of the soil. These aspects have a direct relation with water quality, thus reaffirming the need to monitor water quality in a way that observes the characteristics of the water resource in the face of anthropic impacts (Costa and Ferreira, 2015).

The Brazilian Federal District (FD) is the Brazilian Federative Unit of the country with the third-lowest surface water availability per capita per year. In recent years, the Federal District has been experiencing strong population growth. In seven years (2010-2017), the total FD population grew $18.2 \%$, more than double the national average (8.1\%) (IBGE, 2017). Population growth in the FD does not only affect water consumption, but also leads to the inadequate use of natural resources, which implies environmental impacts. Thus, effective and rapid methods to monitor water quality are often necessary for the FD (Bilich and Lacerda, 2005).

In Brazil, the main tools related to the monitoring of water quality are the Water Quality Index (WQI) proposed by the São Paulo State Environmental Company (CETESB) (Zagatto et al., 1999; ANA, 2018), and the maximum values allowed by Resolution 357/05 of Brazilian Environment Council (CONAMA, 2005). Although these tools are important, they do not consider the multiple uses of water or regional characteristics, respectively (Passos et al., 2018). WQIs aim to give a unique value to the quality of the water body, so the formulation and use of indices have been strongly defended by agencies responsible for the supply and control of water pollution. Since data on water quality are collected through sampling and analysis, the need arises to translate the results in a way that is easily understood (Abbasi and Abbasi, 2012).

It is worth noting that Brazil, as a country with a continental dimension and different

Rev. Ambient. Água vol. 14 n. 4, e2385 - Taubaté 2019 
regional conditions, with wide climatic and geomorphological variation, possessing seven biomes, three ecotones and 79 ecoregions (Arruda et al., 2008), exemplifies how necessary it is to know the characteristics of water (Oliveira-Filho et al., 2014). This is because the impacts of any activity on water bodies can only be measured if there is prior knowledge of the natural conditions of the resource.

Variable selection is the first and most important step in the composition of any WQI. In an attempt to reduce subjectivity in the selection of variables, statistical analyses such as Principal Component Analysis (PCA) have been widely adopted (Abassi and Abassi, 2012). For Bollman and Marques (2000), the use of statistical calculations in the selection of variables aims to reduce uncertainties and increase the applicability of the indices. In this context, the present work aims to select more appropriate variables with the natural configuration of the Brazilian Federal District (FD), by means of PCA, to compose a water quality index for FD water bodies. According to Lemos (2011), water quality is determined by its physical, chemical and microbiological characteristics; however, quality is a very broad term and has as its basis the intended use. As in the present study there was no specific direction for the use of water, the water in its natural condition was understood as being of standard quality. Therefore, the interruption or modification of the natural conditions was considered to represent a change in the natural quality, making it possible to characterize variables of regional importance.

\section{MATERIALS AND METHODS}

\subsection{Study Areas and Sample Collection}

The Federal District is located in central Brazil, with an area of 5,789.16 km² (Barbosa, 2010), representing the soil diversity of the Cerrado (savanna) region. It is in the Central Plateau ecoregion, with a significant geoenvironmental variety (Arruda et al., 2008), reaching altitudes of up to 1,300 meters (Bilich and Lacerda, 2005). About $85 \%$ of FD soils are represented by the classes of Red Latosol, Yellow Red Latosol and Cambisol (Campos and Silva, 2000). The climate is characteristic of the Cerrado biome, with well-defined seasons: rainy summer and dry winter. In April, the dry season begins, ending around September; from October to March higher rainfall rates can be observed (Muniz et al., 2011).

In the Federal District, the São Bartolomeu Basin is the one with the largest extension, covering approximately $50 \%$ of the total area, representing $2,864.05 \mathrm{~km}^{2}$ (Barbosa, 2010). The sub-basins belonging to the São Bartolomeu River have significant importance in the activities of rural and urban areas. Its area consists of rural training and agricultural activities that correspond to approximately $70 \%$ of the area, and urbanization corresponds to approximately $4 \%$ of the area (Ferreira, 2006; Sena-Souza et al., 2013). Although urbanization is present in a smaller part of this river basin, it presents considerable impacts, since the disorderly urban expansion from the 90's generated environmental degradation in the area (Barbosa, 2010).

In order to identify the characteristics of the surface waters of the Federal District and to qualify the variables, one river and two streams were examined: Jardim River, from the Rio Preto Basin; and Sobradinho and Sarandi Streams, from the São Bartolomeu Basin (Figure 1). The fact that there was a natural area or an area under use, whether urban or agricultural, was considered for the selection. The fact that there was both natural or areas under human use, either under urban or agricultural, it was a factor taken under consideration for sample selection.

The water bodies selected in the São Bartolomeu River Basin were Sobradinho and Sarandi Streams, an urban and rural water body, respectively. Sobradinho Stream rises in the Canastra hill and is the main water body of the Hydrographic Unit of Ribeirão Sobradinho. It presents an altimetry amplitude of approximately $350 \mathrm{~m}$ and average annual temperature around $22^{\circ} \mathrm{C}$. In relation to land use and occupation, this region is marked by intense subdivision, which has increased significantly since the 1990s (Zoby and Duarte, 2001). Sarandi Stream is a tributary 
of the right bank of the Mestre d'Armas River, both belonging to the Hydrographic Unit of the Upper São Bartolomeu River, located in the north of the Federal District, with a drainage area of approximately $30 \mathrm{~km}^{2}$. The use and occupation of the soil of this area is characterized by agricultural activities and land allotments (Assis et al., 2013; Carvalho, 2005).

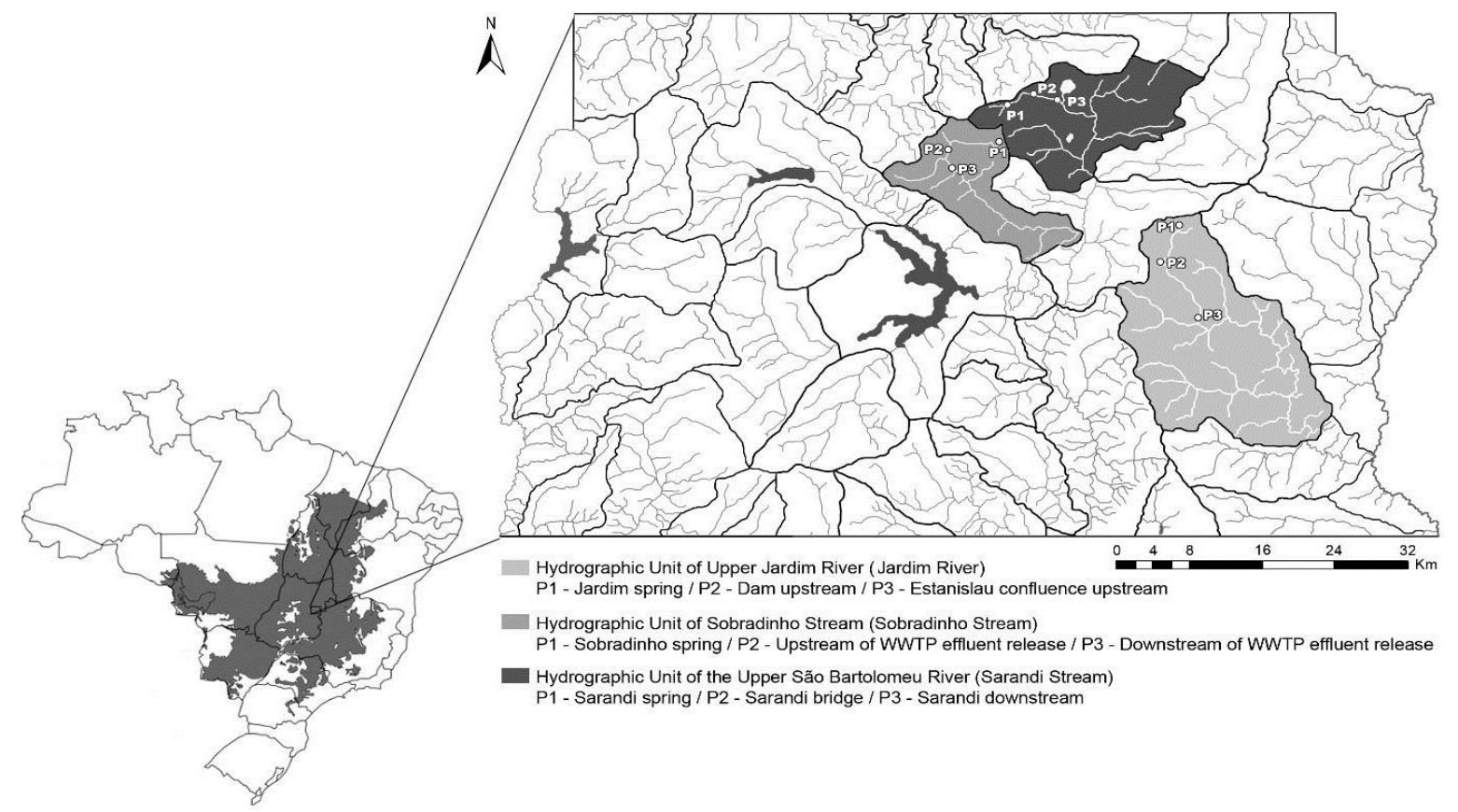

Figure 1. Location of the study area.

The Rio Preto Basin includes, besides the Federal District (12.94\%), the states of Goiás (22.01\%) and Minas Gerais (65.05\%), so it is defined as a federal river. In the Federal District, this hydrographic basin corresponds to approximately $23 \%$ of the total area, with drainage of $1,343.75 \mathrm{Km}^{2}$ (Barbosa, 2010). Its use is mainly for agriculture, and it is responsible for about $80 \%$ of the agricultural production of the Federal District. The Rio Preto Basin is a major contributor to the São Francisco River, which is an important source of energy generation, irrigation and supply of human needs (Oliveira-Filho and Parron, 2007).

The Jardim River comprises a total drainage area of $141.8 \mathrm{~km}^{2}$. It is located in the Hydrographic Unit of the Upper Jardim River, east of the Federal District, framed in the Rio Preto Basin, which is an affluent of the Paracatu River, a considerable tributary of the São Francisco River (Castro et al., 2016). It is a predominantly rural area with intense agricultural activity (Vieira et al., 2018), used for the cultivation of several crops, leaving few areas of its natural vegetation bordering the river (Lima, 2010).

The collection points were defined based on the representativeness of the point in the river and the safety of sampling. Previous studies in the basins also helped to define the sampling sites (Muniz et al., 2011; Pires et al., 2015), and the surveys carried out at the sites contributed information about the characteristics of the areas and the main polluting activities of the region (ANA, 2012). The springs were selected to observe the natural characteristics of the rivers, without direct anthropogenic interference. The other two points were aimed at assessing the impact of different human activities on the river. Samplings occurred monthly between August 2016 and July 2017, with 12 samplings from each point in each water body, totaling 108 samples, 36 from each river.

In the Sobradinho Stream, the collection points were denominated: P1, Sobradinho Spring (15 37'59' S and 47 46'21' W); P2, upstream of WWTP (wastewater treatment plant) effluent

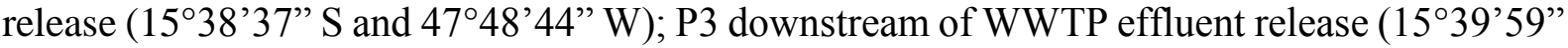


S and $\left.47^{\circ} 48^{\prime} 32^{\prime \prime} \mathrm{W}\right)$. In the Sarandi Stream, collection points were described as: P1, Sarandi

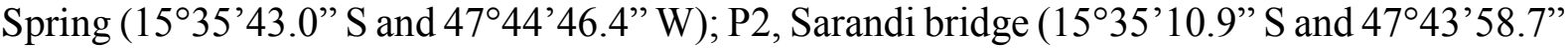

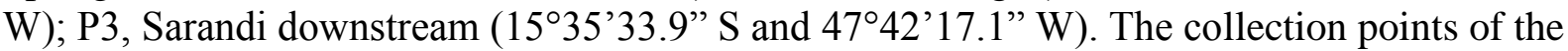

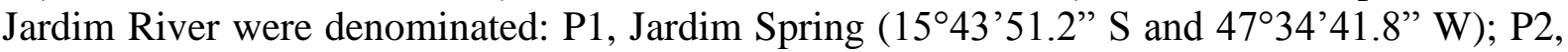
dam upstream $\left(15^{\circ} 45^{\prime} 54.9^{\prime \prime} \mathrm{S}\right.$ and $\left.47^{\circ} 35^{\prime} 34.80^{\prime \prime} \mathrm{W}\right)$; P3, Estanislau confluence upstream $\left(15^{\circ} 49^{\prime} 44.3 " \mathrm{~S}\right.$ and $\left.47^{\circ} 33^{\prime} 28.9^{\prime \prime} \mathrm{W}\right)$.

In the water body, about $40 \mathrm{~cm}$ from the river bank, the properly prepared $300 \mathrm{ml}$ polyethylene bottles were dipped into the water to a depth of approximately $30 \mathrm{~cm}$. After collection, the vial was stored in a cool box under refrigeration and protected from light until it reached the laboratory for analysis. For determination of total coliforms and Escherichia coli, samples were collected in appropriate sterile containers containing sodium thiosulfate, 0.1 $\mathrm{mg} / 100 \mathrm{~mL}$ sample. All samples were subjected to physical, chemical and microbiological analysis. Samples destined for ionic analysis by chromatography were filtered through a hydrophilic membrane, consisting of mixtures of cellulose esters with $0.45 \mu \mathrm{m}$ porosity and frozen until the moment of analysis.

\subsection{Laboratory and Statistical Analysis}

For each sample, 21 variables were analyzed: 19 physicochemical and 2 microbiological variables: temperature (TEMP), dissolved oxygen (DO), $\mathrm{pH}$, electrical conductivity (EC), total dissolved solids (TDS), turbidity (TURB), total hardness (TH), total dissolved phosphorus (TDP), sodium $\left(\mathrm{Na}^{+}\right)$, potassium $\left(\mathrm{K}^{+}\right)$, ammonium $\left(\mathrm{NH}_{4}{ }^{+}\right)$, calcium $\left(\mathrm{Ca}^{2+}\right)$, magnesium $\left(\mathrm{Mg}^{2+}\right)$, fluoride $\left(\mathrm{F}^{-}\right)$, chloride $\left(\mathrm{Cl}^{-}\right)$, nitrite $\left(\mathrm{NO}_{2}{ }^{-}\right)$, nitrate $\left(\mathrm{NO}_{3}{ }^{-}\right)$, phosphate $\left(\mathrm{PO}_{4}{ }^{3^{-}}\right)$, sulfate $\left(\mathrm{SO}_{4}{ }^{2-}\right)$, total coliforms and Escherichia coli (E. coli).

The variables temperature and dissolved oxygen were obtained in the field with the use of a portable multiparameter meter HQ40d Hach, and the other analyses were carried out in the Embrapa Cerrados Water Chemistry Laboratory in compliance with the Brazilian Association of Technical Standardization (ABNT, 1992) and the 22nd edition of Standard Methods for the Examination of Water and Wastewater - SMEWW (APHA, 2012).

In the statistical analyses, the data matrix of Sobradinho Stream, Sarandi Stream and Jardim River were submitted to descriptive statistics (mean and standard deviation), in order to synthesize the data to have an overview of the results.

Principal Component Analysis (PCA) was used to rewrite multivariate data (Lattin et al., 2011). With this analysis, it was possible to observe similar variables that can have the same meaning in terms of water quality. PCA provides a smaller view of the data that are in high dimensions, and explains as much of the data variance as possible in its first components (axes). The results of the PCAs of this study helped to select variables that contributed to the greater variability in water quality for the proposal of a water quality index for the DF. The statistical treatment of the data was carried out using software R version 3.4.2 (R Core Team, 2017). In the PCA analysis, the 'vegan' packages were used (Oksanen et al., 2017) and 'FactoMineR' (Le et al., 2008).

\section{RESULTS AND DISCUSSION}

\subsection{Physical and Chemical Analyses}

The data of the 19 physical-chemical variables obtained in this study show a significant difference between the water quality of Sobradinho Stream and Sarandi Stream and Jardim River (Table 1). The change in the values of P1 (spring) to P3 (downstream of the WWTP) of Sobradinho Stream occurred in more variables and in a greater proportion than in the other two rivers. Observing the averages of each physicochemical parameter of Sobradinho Stream (Table 1), it is possible to verify that the TDS increased about 90 times from P1 to P3, the hardness increased by about 70 times, ammonium showed an increase of about 50 times from the source 
to the P3, the conductivity increased approximately 40-fold, the chloride had a magnification of about 25 times, total dissolved phosphorus and nitrate increased approximately 20-fold and potassium and turbidity also increased by about 15 and 10 times, respectively from P1 to P3.

The TDS is the junction of dissolved chemical compounds in water; its main sources are agricultural activities, point sources such as WWTP and industrial outflow (Parron et al., 2011), and this would explain its considerable increase in P3, due to the WWTP point of Sobradinho. The same applies to the increase in hardness, which indicates contamination in the water, since it is a natural characteristic of it to present extremely low values in environments without direct anthropogenic interference (Aquino et al., 2009). The main ions that provide hardness in water are calcium and magnesium, which are often interconnected with sulfate ions (Di Bernardo and Dantas, 2005).

The variables total dissolved phosphorus (TDP), potassium $\left(\mathrm{K}^{+}\right)$and ammonium $\left(\mathrm{NH}_{4}{ }^{+}\right)$ follow the same pattern, with the highest values found in P3 and the lowest values in P1. These variables extrapolated the values allowed in P3 in several months (CONAMA, 2005). According to Parron et al. (2011), high values of these variables may indicate contamination of raw sewage, transport of fertilizers and industrial effluents.

Chloride $\left(\mathrm{Cl}^{-}\right)$is strongly related to the discharge of sanitary sewage, since human excreta contain a high amount of this element (WHO, 2017), which explains its increase in P3. However, even though P3 shows the highest value for this parameter, it is still lower than the maximum values allowed by CONAMA, which is $250 \mathrm{mg}$. $\mathrm{L}^{-1}$. In some months, $\mathrm{P} 3 \mathrm{Nitrate} \mathrm{NO}_{3}{ }^{-}$ exceeded the values stipulated by CONAMA Resolution 357/2005, with the majority of these months in the dry period. It is believed that the reduction in water volume increased $\mathrm{NO}_{3}{ }^{-}$. The $\mathrm{NO}_{3}{ }^{-}$and $\mathrm{Cl}^{-}$are considered relevant ions in the indication of contamination by urban effluents (Muniz et al., 2011).

The study by Muniz et al. (2011) in Sobradinho Stream also showed considerable changes in the water quality as it approached the urban area. Urbanization is strongly connected with the decrease in water quality (Silva et al., 2009), with P3 being within an urban environment. As in this study, Muniz et al. (2011) found the highest DO values at the spring and their lowest values at P3. CONAMA Resolution $\mathrm{N}^{\circ} 357 / 2005$ states that Class I fresh water must not have DO of less than $6 \mathrm{mg} . \mathrm{L}^{-1}$, Class II must not be less than $5 \mathrm{mg} . \mathrm{L}^{-1}$ and Class III not less than 4 mg. $\mathrm{L}^{-1}$; that is, the minimum found in the creek is below the value determined for Class IV of the CONAMA resolution framework, in which it indicates that the DO should not be less than $2 \mathrm{mg} . \mathrm{L}^{-1}$. This is probably due to the location of P3, which is downstream of Sobradinho's WWTP outflow, at a distance of approximately 600 meters (INPE, 2018). The bacteria that are present in large amounts in the WWTP effluent use oxygen in their respiratory processes during the stabilization of organic matter, which may contribute to the reduction of DO levels in water (Alves et al., 2008). The electrical conductivity (EC) showed a considerable increase downstream of the WWTP. Because this parameter is related to the presence of ions in the water body, the more inorganic compounds are present in the solution, the greater its conductivity (APHA, 2012).

Slightly acidic values and low $\mathrm{pH}$ variation were also observed. The slightly acidic $\mathrm{pH}$ is a characteristic of Cerrado waters, which reproduce the acidity of the soils of this biome (Pires et al., 2015). Sarandi Stream and Jardim River presented fewer variables with large changes between P1 and P3 (Table 1). In Sarandi, only nitrate, turbidity and TDS increased considerably, even though in much lower proportions than in Sobradinho. The nitrate increased about 6 times and the turbidity about 4 times, and the TDS almost doubled. In the Jardim River, in addition to the TDS, which also almost doubled from P1 to P3, nitrate increased by approximately 23 times, regarding the mean of P1 to the mean of P3, while fluoride increased about 5 times, and the potassium, calcium, magnesium and conductivity almost doubled. 
Table 1. Descriptive statistics of the physical and chemical variables analyzed at the collection points of Sobradinho Stream, Sarandi stream and Jardim river.

\begin{tabular}{|c|c|c|c|c|c|c|c|c|c|c|c|c|c|c|c|c|c|c|}
\hline \multirow{3}{*}{ Variables } & \multicolumn{6}{|c|}{ Sobradinho Stream } & \multicolumn{6}{|c|}{ Sarandi Stream } & \multicolumn{6}{|c|}{ Jardim river } \\
\hline & \multicolumn{3}{|c|}{$\mathbf{M}$} & \multicolumn{3}{|c|}{ SD } & \multicolumn{3}{|c|}{$\mathbf{M}$} & \multicolumn{3}{|c|}{ SD } & \multicolumn{3}{|c|}{$\mathbf{M}$} & \multicolumn{3}{|c|}{ SD } \\
\hline & P1 & $\mathbf{P 2}$ & P3 & P1 & $\mathbf{P 2}$ & P3 & P1 & $\mathbf{P 2}$ & P3 & $\mathbf{P 1}$ & $\mathbf{P 2}$ & P3 & $\mathbf{P 1}$ & $\mathbf{P 2}$ & P3 & P1 & $\mathbf{P 2}$ & P3 \\
\hline $\mathrm{TEMP}^{\circ} \mathrm{C}$ & 22.75 & 21.36 & 21.40 & 1.26 & 1.24 & 0.93 & 21.48 & 23.78 & 22.64 & 1.46 & 1.29 & 1.41 & 21.65 & 21.86 & 22.18 & 1.20 & 1.39 & 1.16 \\
\hline $\mathrm{DO}\left(\mathrm{mg} \mathrm{L}^{-1}\right)$ & 5.56 & 5.65 & 3.04 & 1.07 & 0.77 & 1.89 & 7.65 & 7.15 & 6.86 & 0.54 & 0.23 & 0.39 & 7.17 & 7.35 & 7.25 & 0.66 & 0.35 & 0.37 \\
\hline $\mathrm{pH}$ & 5.23 & 6.45 & 6.80 & 0.54 & 0.25 & 0.48 & 6.15 & 5.96 & 5.56 & 0.45 & 0.59 & 0.47 & 5.94 & 5.95 & 5.98 & 0.49 & 0.49 & 0.50 \\
\hline $\mathrm{EC}(\mu \mathrm{S} / \mathrm{cm})$ & 4.57 & 62.80 & 170.4 & 1.61 & 22.47 & 77.96 & 3.88 & 5.02 & 5.88 & 0.81 & 0.71 & 1.21 & 3.98 & 7.57 & 7.85 & 1.03 & 1.64 & 4.10 \\
\hline TDS $\left(\mathrm{mg} \mathrm{L}^{-1}\right)$ & 1.81 & 33.26 & 90.01 & 0.73 & 6.48 & 36.70 & 1.37 & 1.89 & 2.38 & 0.44 & 0.36 & 0.60 & 1.89 & 3.14 & 3.29 & 1.74 & 0.76 & 1.93 \\
\hline $\mathrm{TH}\left(\mathrm{mg} \mathrm{L}^{-1}\right)$ & 0.40 & 16.25 & 70.08 & 0.76 & 10.28 & 88.52 & 2.83 & 2.50 & 3.21 & 1.70 & 1.31 & 1.50 & 3.83 & 4.83 & 4.33 & 2.08 & 3.33 & 2.71 \\
\hline TURB (UNT) & 3.80 & 13.44 & 35.59 & 5.57 & 13.74 & 33.70 & 2.63 & 3.63 & 10.11 & 1.94 & 2.29 & 15.53 & 6.12 & 12.55 & 9.67 & 4.68 & 13.26 & 6.42 \\
\hline $\mathrm{TDP}\left(\mathrm{mg} \mathrm{L}^{-1}\right)$ & 0.024 & 0.023 & 0.396 & 0.02 & 0.04 & 0.27 & 0.002 & 0.002 & 0.001 & 0.001 & 0.001 & 0.001 & 0.007 & 0.002 & 0.018 & 0.001 & 0.001 & 0.05 \\
\hline $\mathrm{Na}^{+}\left(\mathrm{mg} \mathrm{L}^{-1}\right)$ & 0.29 & 0.43 & 0.74 & 0.12 & 0.64 & 0.98 & 0.15 & 0.19 & 0.15 & 0.15 & 0.20 & 0.14 & 0.50 & 0.44 & 0.55 & 0.30 & 0.17 & 0.19 \\
\hline $\mathrm{K}^{+}\left(\mathrm{mg} \mathrm{L}^{-1}\right)$ & 0.17 & 3.44 & 15.92 & 0.26 & 2.90 & 11.53 & 0.17 & 0.33 & 0.22 & 0.09 & 0.23 & 0.20 & 0.32 & 0.26 & 0.58 & 0.32 & 0.17 & 0.82 \\
\hline $\mathrm{NH}_{4}{ }^{+}\left(\mathrm{mg} \mathrm{L}^{-1}\right)$ & 0.71 & 16.06 & 32.20 & 0.47 & 8.42 & 19.72 & 0.81 & 1.40 & 1.03 & 0.23 & 0.72 & 0.74 & 1.28 & 1.71 & 3.09 & 1.24 & 3.30 & 6.86 \\
\hline $\mathrm{Ca}^{2+}\left(\mathrm{mg} \mathrm{L}^{-1}\right)$ & 3.12 & 9.55 & 12.74 & 2.15 & 4.47 & 1.95 & 1.46 & 1.56 & 1.78 & 0.23 & 0.21 & 0.39 & 1.67 & 2.40 & 3.00 & 1.46 & 2.08 & 4.21 \\
\hline $\mathrm{Mg}^{2+}\left(\mathrm{mg} \mathrm{L}^{-1}\right)$ & 0.23 & 0.94 & 1.74 & 0.16 & 0.37 & 0.43 & 0.30 & 0.29 & 0.26 & 0.06 & 0.07 & 0.10 & 0.30 & 0.49 & 0.57 & 0.21 & 0.21 & 0.49 \\
\hline $\mathrm{Fl}^{-}\left(\mathrm{mg} \mathrm{L}^{-1}\right)$ & 0.02 & 0.05 & 0.18 & 0.03 & 0.09 & 0.10 & 0.03 & 0.02 & 0.01 & 0.05 & 0.04 & 0.02 & 0.01 & 0.03 & 0.05 & 0.02 & 0.03 & 0.05 \\
\hline $\mathrm{Cl}^{-}\left(\mathrm{mg} \mathrm{L}^{-1}\right)$ & 0.96 & 6.78 & 22.76 & 2.07 & 3.22 & 13.72 & 0.47 & 0.69 & 0.64 & 0.19 & 0.31 & 0.38 & 0.57 & 1.15 & 1.79 & 0.31 & 2.05 & 4.26 \\
\hline $\mathrm{NO}_{2}^{-}\left(\mathrm{mg} \mathrm{L}^{-1}\right)$ & n.d & n.d & 12.81 & 0.01 & n.d & 29.68 & 0.03 & n.d & n.d & 0.09 & n.d & n.d & n.d & n.d & n.d & n.d & n.d & n.d \\
\hline $\mathrm{NO}_{3}^{-}\left(\mathrm{mg} \mathrm{L}^{-1}\right)$ & 0.79 & 6.02 & 14.99 & 1.70 & 3.56 & 24.89 & 0.06 & 0.08 & 0.37 & 0.09 & 0.14 & 0.33 & 0.08 & 0.49 & 1.83 & 0.08 & 1.10 & 5.52 \\
\hline $\mathrm{PO}_{4}{ }^{3-}\left(\mathrm{mg} \mathrm{L}^{-1}\right)$ & n.d & n.d & 2.25 & n.d & n.d & 2.43 & n.d & n.d & n.d & n.d & n.d & n.d & n.d & n.d & 0.09 & n.d & n.d & 0.30 \\
\hline $\mathrm{SO}_{4}{ }^{2-}\left(\mathrm{mg} \mathrm{L}^{-1}\right)$ & n.d & 0.15 & 0.20 & n.d & 0.36 & 0.49 & n.d & n.d & n.d & n.d & n.d & n.d & n.d & 0.01 & 0.01 & n.d & 0.02 & 0.02 \\
\hline
\end{tabular}

$\mathrm{M}=$ Mean $/ \mathrm{DP}=$ Standard Deviation $/ \mathrm{P} 1=$ Point $1 / \mathrm{P} 2=$ Point $2 / \mathrm{P} 3=$ Point 3/ TEMP $=$ Temperature $/ \mathrm{DO}=$ Dissolved oxygen $/ \mathrm{EC}=$ Electrical conductivity $/ \mathrm{TDS}=$ Total dissolved solids $/ \mathrm{TH}=$ Total hardness $/ \mathrm{TURB}=$ Turbidity $/ \mathrm{TDP}=$ Total Dissolved Phosphorus $/$ n.d $=$ non detected . 
In the rivers of the rural area the parameter with the greatest variation was nitrate. This increase can be explained by the agricultural activity of the region (Aquino et al., 2009). Both rivers presented values lower than those found in Sobradinho Stream, and the anthropogenic interference is different. This was because in Sobradinho Stream, the wastewater treatment plant (WWTP) was observed as clearly being the main source of water quality changes, whereas in Sarandi Stream and Jardim River, which are located in rural environments, the main interference is agriculture and livestock. The widespread agricultural activity in the Jardim River region, which leads to intense use of agrochemicals, can cause water contamination (Muniz et al., 2011), which is the possible explanation for the increase of nitrate at P3 of this river.

A common feature observed in the three monitored water bodies is the low values detected in their springs for the hardness, and it is natural for these waters to always have low hardness (Aquino et al., 2009; Muniz et al., 2011; Oliveira-Filho et al., 2014); thus, it is believed that when this parameter changes, resulting in higher values, it signals the point at which anthropic interference occurs.

\subsection{Total Coliforms and $E$. coli}

In the results of the microbiological analyses of Sobradinho Stream, high values were observed for Total Coliforms (TC) at P2 and P3 for all samples taken. With the exception of P2 in June, all samples were detected with values > 2,419.6 MPN (Most Probable Number) / 100 mL. According to CONAMA Resolution No. 357/2005, total coliforms are acceptable up to the value of 5,000 MPN / $100 \mathrm{~mL}$. Also according to this standard, Class III waters used in recreation of secondary contact should not exceed the limit of 2,500 MPN / $100 \mathrm{~mL}$ in $80 \%$ or more of at least 6 samples, and for the watering of animals raised in confinement the limit is $1,000 \mathrm{NMP} / 100 \mathrm{~mL}$ in $80 \%$ or more of at least 6 samples. E. coli showed the lowest values at P1 and the highest values at P3, as well as TC. P1 and P2 presented acceptable values for the use of secondary-contact recreation, as well as for watering animals in confinement. In contrast, P3 exceeded all limits determined by CONAMA throughout the E. coli sampling for the use of the stipulated activities. The main explanation for the high values of TC and mainly of $E$. coli at P3 of Sobradinho is the release of WWTP effluents. The presence of E. coli in the water bodies means there is fecal contamination through these microorganisms (Silva and Bringuel, 2007).

At P1 of Sarandi Stream the TC value was the highest among the three rivers. In some months, the P2 of both Sarandi and Jardim presented values > 2,419.6 MPN / $100 \mathrm{~mL}$, and in Jardim this value was found more frequently at P2 and Sarandi at P3. The values found in these two water bodies are within the allowed limits (CONAMA, 2005).

The $E$. coli amounts found in these water bodies are probably associated with animal feces (cattle ranching) and a small amount of untreated sewage (Aquino et al., 2009; Muniz et al., 2011).

CONAMA Resolution No. 357/2005 (CONAMA, 2005) was used throughout the research, with the minimum and maximum values stipulated as the basis for qualifying each parameter.

\subsection{Principal Component Analysis}

Before the principal component analyses (PCA) took place, Kaiser-Meyer-Olkin index (KMO) and Bartlet Sphericity Test (BST) measurements were carried out. For Hair et al. (2009), KMO values greater than 0.5 to 1.0 are considered acceptable for PCA application. The result of the KMO index obtained in the first study matrix was 0.79 and the BST was considered significant $(<0.000, \mathrm{p}<0.05)$.

Principal component analysis (PCA) was performed on the total set of normalized data (21 variables) for the 9 sampling points in order to observe the dispersion diagram of the three water bodies (Figure 2). 


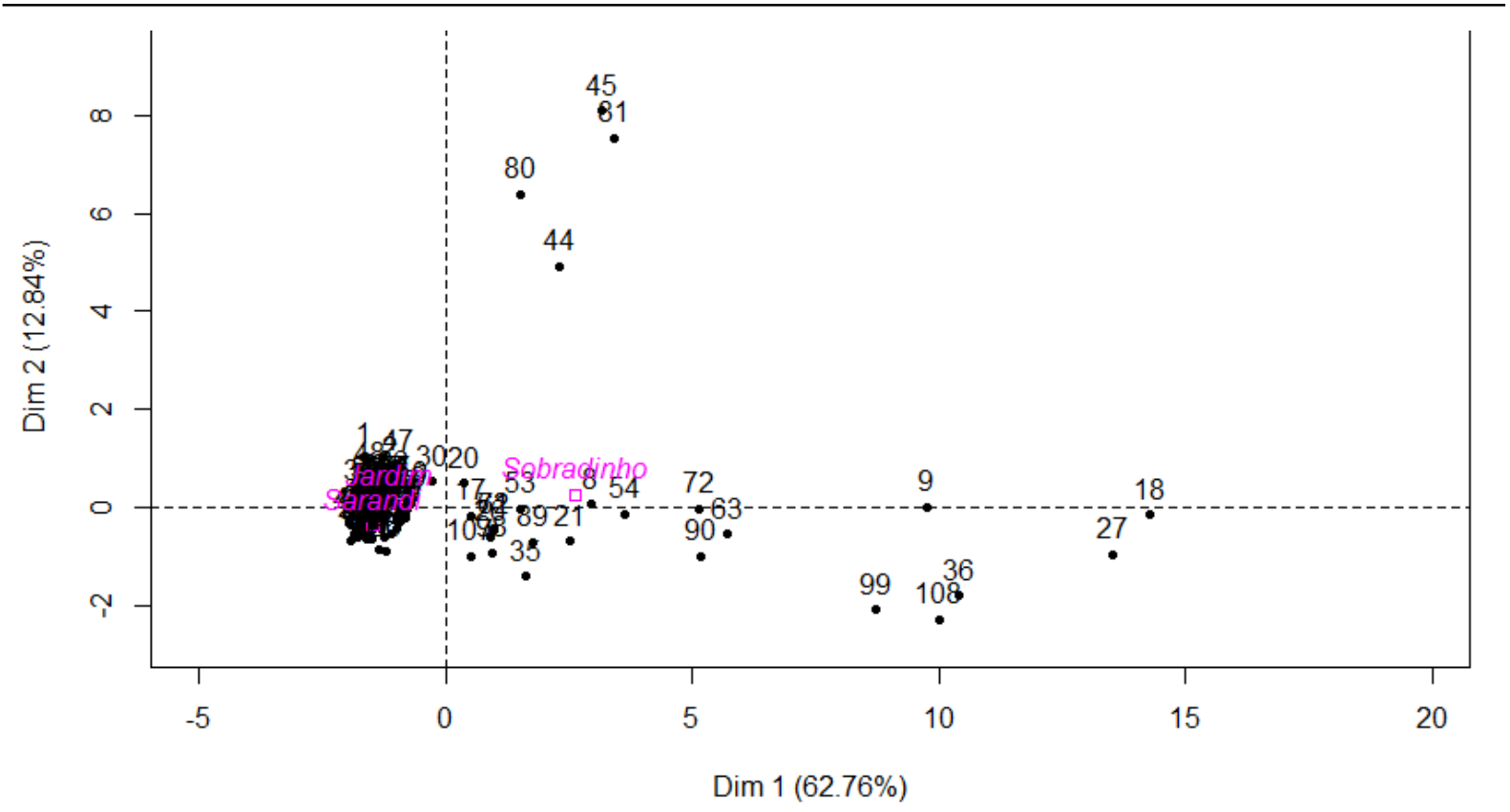

Figure 2. Dispersion diagram of water bodies sampled in main components 1 and 2.

It is possible to observe how the general characteristics of Sobradinho differ from Sarandi and Jardim, and how the latter two are similar. The probable explanation for this is that Sobradinho Stream is an urban water body, with a specific source of pollution provided by Sobradinho's WWTP, while the similarity between Sarandi and Jardim is possibly due to the fact that both are in rural areas, with agriculture and livestock as a source of anthropogenic contamination.

After the result of the dispersion diagram (Figure 2), showing the difference between Sobradinho and the other two rivers, a PCA was generated from Sobradinho Stream and a PCA with Sarandi Stream and Jardim River together (Table 2), in order to observe the ordered variables.

For the Sobradinho Stream data set $(\mathrm{KMO}=0.82$ and BST $=\mathrm{p}<0.000)$ and the Sarandi Stream and Jardim River $(\mathrm{KMO}=0.77$ and $\mathrm{BST}=\mathrm{p}<0.000)$ the first two components $(\mathrm{PC} 1$ and PC2) were selected, because they presented eigenvalues $>1$, based on the Kaiser criterion, and the total percentage explained between 70 and $90 \%$ according to the criterion adopted by Jolliffe (Kaiser, 1958; Jolliffe, 2002). In studies that use PCA in water quality assessment, the first two or three major components generated account for much of the variation in the original data. In most cases these components are sufficient to describe the entire data matrices without significant loss of information (Simeonov et al., 2003). A Varimax normalization was applied as a rotation method in the analysis of the main components for better interpretation of the results. For Sobradinho Stream, the two components explained $75.06 \%$ of the original data variation, while in Sarandi Stream and Jardim River the total variation explained by the three components was $80.77 \%$ (Table 2).

Loads greater than 0.75 were established to consider the variable with an important load in the main component. Liu et al. (2003) classified values of absolute load>0.75, 0.75-0.5 and 0.5-0.3 as strong, moderate and weak, respectively. For the Sobradinho Stream data set, the variables DO, EC, TDS, potassium, ammonium, magnesium, fluoride, chloride, phosphate and E. coli presented loads above 0.75 for PC1 and the sodium and sulfate variables likewise in PC2. In the data set of Sarandi Stream and Jardim River, TDP, potassium, ammonium, calcium, magnesium, chloride, nitrate and phosphate presented strong loads in PC1, while EC, TDS and sulfate had loads $>0.75$ in PC2 (Table 2). 
Table 2. Loadings of the main components, eigenvalues, percentage of variation and total percentage explained by the monitoring of the sampled water bodies.

\begin{tabular}{lcccc}
\hline \multirow{2}{*}{ Variables } & \multicolumn{2}{c}{ Sobradinho Stream } & Sarandi Stream and Jardim River \\
\cline { 2 - 5 } & $\mathbf{P C 1}$ & $\mathbf{P C 2}$ & $\mathbf{P C 1}$ & PC2 \\
\hline Temperature (TEMP) & -0.397 & -0.391 & -0.008 & -0.000 \\
Dissolved Oxygen (DO) & $\mathbf{- 0 . 8 3 2}$ & 0.021 & -0.126 & -0.116 \\
pH & 0.743 & 0.118 & -0.014 & 0.316 \\
Electrical Conductivity (EC) & $\mathbf{0 . 9 1 8}$ & 0.047 & 0.248 & $\mathbf{0 . 8 7 3}$ \\
Total Dissolved Solids (TDS) & $\mathbf{0 . 9 6 5}$ & -0.013 & 0.232 & $\mathbf{0 . 8 3 1}$ \\
Total Hardness (TH) & $\mathbf{0 . 7 5 6}$ & 0.069 & 0.228 & 0.528 \\
Turbidity $(\mathrm{TURB})$ & 0.636 & 0.347 & 0.006 & 0.065 \\
Total Dissolved Phosphorus (TDP) & 0.321 & 0.337 & $\mathbf{0 . 9 3 4}$ & -0.170 \\
Sodium $\left(\mathrm{Na}^{+}\right)$ & 0.093 & $\mathbf{0 . 8 6 9}$ & 0.042 & 0.165 \\
Potassium $\left(\mathrm{K}^{+}\right)$ & $\mathbf{0 . 8 8 1}$ & -0.218 & $\mathbf{0 . 8 7 6}$ & -0.096 \\
Ammonium $\left(\mathrm{NH}_{4}{ }^{+}\right)$ & $\mathbf{0 . 8 5 2}$ & -0.342 & $\mathbf{0 . 9 5 8}$ & -0.120 \\
Calcium $\left(\mathrm{Ca}^{2+}\right)$ & 0.721 & 0.253 & $\mathbf{0 . 9 4 8}$ & -0.034 \\
Magnesium $\left(\mathrm{Mg}^{2+}\right)$ & $\mathbf{0 . 9 0 4}$ & 0.114 & $\mathbf{0 . 8 9 1}$ & -0.001 \\
Fluoride $\left(\mathrm{F}^{-}\right)$ & $\mathbf{0 . 8 1 3}$ & -0.261 & 0.392 & 0.104 \\
Chloride $\left(\mathrm{Cl}^{-}\right)$ & $\mathbf{0 . 9 2 8}$ & -0.245 & $\mathbf{0 . 9 6 1}$ & -0.074 \\
Nitrite $\left(\mathrm{NO}_{2}^{-}\right)$ & 0.448 & -0.248 & -0.038 & -0.050 \\
Nitrate $\left(\mathrm{NO}_{3}{ }^{-}\right)$ & 0.456 & -0.294 & $\mathbf{0 . 9 7 3}$ & -0.103 \\
Phosphate $\left(\mathrm{PO}_{4}{ }^{3-}\right)$ & $\mathbf{0 . 7 9 8}$ & -0.168 & $\mathbf{0 . 9 3 9}$ & -0.160 \\
Sulfate $\left(\mathrm{SO}_{4}{ }^{-}\right)$ & -0.019 & $\mathbf{0 . 9 4 6}$ & 0.007 & $\mathbf{0 . 7 8 0}$ \\
Total Coliforms $(\mathrm{TC})$ & 0.599 & 0.359 & 0.093 & 0.132 \\
Escherichia coli $($ E. coli) & $\mathbf{0 . 8 0 1}$ & 0.404 & 0.152 & 0.471 \\
Eigenvalue & 9.610 & 2.400 & 7.199 & 2.494 \\
\% of Variation & 60.06 & 15.00 & 59.99 & 20.78 \\
\% Explained total & 75.06 & & 80.77 & \\
& & & &
\end{tabular}

\subsection{Proposal of variables for a regional WQI}

The differences observed in all the analyses of this work demonstrate the necessity of two separate groups of variables to constitute the FD Water Quality Index, one being an index for rivers in the urban environment and the other for rivers in the rural environment. For the proposal of these two groups of variables in the formation of WQIs for FD, the results of the PCA of Sobradinho Stream (Table 2) and PCA of Sarandi Stream and Jardim River together (Table 2) were considered, and the data of the physical and microbiological analyses (Table 1).

Electrical conductivity is a very significant variable in the analysis of water quality, since it can warn about high levels of many inorganic variables in the rivers. Besides the inorganic ions, it also shows good correlation with other variables. The conductivity showed a correlation with several inorganic ions in Sobradinho Stream, which can be interpreted as a warning for river pollution. This parameter was incorporated in the quality index of the urban and rural rivers, since its high values can signal the presence of possible contaminations and impacts undergone by rivers (Wanick et al., 2011) and mainly modifications in their mineral concentration (CETESB, 2009).

The TDS were also ordered in all PCAs, but the correlation between TDS and conductivity is high, so that only the conductivity will be proposed for the WQI of FD. Chloride was also selected in all PCAs, and is part of the proposal in the group of variables for urban and rural 
WQIs. Calcium was selected in the rural area, since this variable presented high loading and being very sensitive to changes in the rural environments studied.

Potassium, ammonium and magnesium variables were also ordered in the PCA of Sobradinho Stream, and of Sarandi Stream and Jardim River. These variables presented changes from P1 to P3 in the analyzed water bodies, and they were therefore suggested for the urban and rural WQIs of the FD.

Phosphate and sulfate appeared in low amounts in all water bodies in this study. The selection of them by PCA must have occurred because they presented a variation. Indeed, at many points their presence was not detected, and at some points in a few months, they were found. However, because they were detected in a few months and in low amounts throughout the monitoring, phosphate and sulfate are not proposed in the urban and rural WQIs of FD. Nitrate and total dissolved phosphorus were selected only in the PCA of the rural water bodies, and both variables are thus suggested in the rural WQI.

The variables that were selected only in the PCA of Sobradinho Stream were DO, total hardness, sodium, fluoride and E. coli. DO presented a negative correlation with several variables, but it was important in the evaluation of the urban water quality of FD.

The total hardness had an increase of about 70 times from P1 to P3 in this river. The water hardness, according to the results of the monitoring of this study, is low in natural waters, such as at a spring, but with the increase of anthropic intervention the values tend to get higher, making this parameter a sign of contamination in the water body. Sodium and fluoride are significant variables, since they may present increased values in water due to effluents from wastewater treatment plants (CETESB, 2009; Parron et al., 2011).

E. coli is the main indicator of fecal contamination and the possible presence of pathogenic organisms (Brasil, 2017); the presence of this bacterium in high concentrations leaves water unfit for various activities (Silva and Bringuel, 2007). Although E. coli was not ordered in the PCA of the rural rivers, but it is an important microbiological parameter, as mentioned above, which meant that it was also incorporated in the rural WQI, mainly due to the potential presence of livestock in those areas.

Thus, among the 21 initial variables analyzed, it was proposed to select 10 variables for the definition of a WQI for urban areas, and 9 variables for a WQI for rural areas of the Brazilian FD. The variables selected for the urbanized regions and the rural regions in the FD are shown in Table 3, in comparison with the original variables from CETESB-WQI (Zagatto et al., 1999).

Table 3. Comparison among variables from original WQI CETESB and proposed by the present study for urban WQI and rural WQI to be defined for FD.

\begin{tabular}{lcc}
\hline WQI CETESB & Urban WQI & Rural WQI \\
\hline Dissolved Oxygen & Dissolved Oxygen & Electrical Conductivity \\
$\mathrm{pH}$ & Electrical Conductivity & Total Dissolved \\
Turbidity & Total Hardness & Phosphorus \\
Biological Oxygen Demand & Sodium & Potassium \\
Total Nitrogen & Potassium & Ammonium \\
Total Phosphorus & Ammonium & Calcium \\
Total Residues & Magnesium & Magnesium \\
Temperature & Fluoride & Chloride \\
Escherichia coli & Chloride & Nitrate \\
& Escherichia coli & Escherichia coli \\
\hline
\end{tabular}




\section{CONCLUSIONS}

The data obtained in this study from the monitoring of the rivers and the characterization of the water quality variables evidenced the differences between the water bodies.

Sobradinho Stream is a water body that is considered urban, because it crosses the town of Sobradinho and receives effluent from the wastewater treatment plant of this town, which considerably changes the quality variables. Sarandi Stream and Jardim River are considered rural water bodies, since both run mainly through an agricultural area. The main non-point source of changes in the water quality of these surface waters is the agricultural activities present near the watercourses.

Thus, based on the regional characteristics of the FD and on quality as meaning the maintenance of the natural condition, the present study evidenced the urgent need to establish two different WQIs for FD water quality. One can be exclusively for the definition of an urban WQI, composed of: DO, electrical conductivity, total hardness, sodium, potassium, ammonium, magnesium, fluoride, chloride and E. coli; and the other for the construction of an eminently rural WQI, consisting of electrical conductivity, total dissolved phosphorus, potassium, ammonium, calcium, magnesium, chloride, nitrate and E. coli. The definition of the weights for each parameter may be objects of other studies, when there is a need to define the respective use of waters.

The use of these variables divided into two groups could minimize water quality conflicts and help with planning and framing issues aiming at better management of water resources in the Brazilian Federal District.

\section{ACKNOWLEDGMENTS}

We thank the Fundação de Amparo à Pesquisa do Distrito Federal (FAP-DF) (process $n^{\circ}$ 193.001.354/2016) for financial support. Leandro Pin Rangel received grants from PIC/UniCEUB and PIBIC/Embrapa in subsequent years.

\section{REFERENCES}

ABBASI, T.; ABBASI, S. A. Water quality indices. [S.l.]: Elsevier, 2012. 362 p.

ABNT. Nbr 12621: Água - Determinação da dureza total - Método titulométrico do EDTA-Na Método de ensaio. Rio de Janeiro, 1992.

ALVES, E. C.; SILVA, C. F.; COSSICH, E. S.; TAVARES, C. R. G.; SOUZA FILHO, E. E.; CARNIEL A. Avaliação da qualidade da água da bacia do rio Pirapó - Maringá, Estado do Paraná, por meio de parâmetros físicos, químicos e microbiológicos. Acta Scientiarum Technology, v. 30, n. 1, p. 39-48, 2008.

ANA (Brasil). Portal da Qualidade das Águas. Available at: http://portalpnqa.ana.gov.br/default.aspx. Access: 20 Dec. 2018.

ANA (Brasil). Panorama da qualidade das águas superficiais do Brasil 2012. Brasília, 2012. 264p.

APHA. Standard methods for the examination of water and wastewater. 22. ed. Washington DC., 2012.

AQUINO, F. G.; VILELA, M. F.; CAMARGO, W. R. F.; CAMARGO, A. J. A.; OLIVEIRAFILHO, E. C.; PASSOS, F. B.; SOUSA, S. R. Uso e cobertura do solo, caracterização biótica e de qualidade da água como subsidio para a elaboração do plano de manejo da área da Embrapa. Planaltina, DF: Embrapa Cerrados, 2009. 50p. 
ARRUDA, M. B.; PROENÇA, C. E. B.; RODRIGUES, S.; MARTINS, E. S.; MARTINS, R. C.; CAMPOS, R. N. Ecorregiões, Unidades de Conservação e Representatividade Ecológica do Bioma Cerrado. In: SANO, S.; ALMEIDA, S.P.; RIBEIRO, J. F. Cerrado: ecologia e flora. Brasília: Embrapa, 2008. v. 1, p. 229-272.

ASSIS, T.; COUTO-JUNIOR, A. F.; NEVES, G.; REATTO, A.; MARTINS, E.S.; GOMES, M. P.; SENA-SOUZA, J. P.; REIS, A. M.; RAMALHO, L. S.; CLAUDINO, V. C. M. Evolução temporal da cobertura da terra de uma bacia experimental do Cerrado utilizando sensoriamento remoto multi sensor e multitemporal. In: SIMPÓSIO BRASILEIRO DE SENSORIAMENTO REMOTO - SBSR, 16., 2013, Foz do Iguaçu, PR. Anais[...] São José dos Campos: INPE, 2013. p. 7739-7745.

BARBOSA, R. P. Avaliação de riscos ambientais na região de Sobradinho, Distrito Federal. Dissertação. 2010. (Mestrado em Planejamento e Gestão Ambiental) Universidade Católica de Brasília, Brasília, 2010.

BILICH, M. R.; LACERDA, M. P. C. Avaliação da qualidade da água do Distrito Federal (DF), por meio de geoprocessamento. SIMPÓSIO BRASILEIRO DE SENSORIAMENTO REMOTO, 12., 2005, Goiânia. Anais[...]São José dos Campos: INPE, 2005. p. 20592065.

BOLLMAN, H. A.; MARQUES, D. M. Bases para Estruturação de Indicadores de Qualidade de Águas. Revista Brasileira de Recursos Hídricos, v. 5, p. 37-60, 2000.

BRASIL. Ministério da Saúde. Gabinete do Ministro. PCR n ${ }^{\circ}$ 5, de 28 de setembro de 2017. Anexo XX. Diário Oficial [da] União, Seção 1, n. 190, Brasília, DF, 03 out. 2017.

CAMPOS, J. E. G.; SILVA, F. H. F. Solos. In: FONSECA, F. O. Olhares sobre o Lago Paranoá. Brasília: Secretaria de Meio Ambiente e Recursos hídricos, 2000.

CARVALHO, P. R. S. A expansão urbana na bacia do Ribeirão Mestre d'Armas (DF) e a qualidade da água. Estudos Geográficos, n. 3, p. 71-91, 2005.

CASTRO, K. B.; ROIG, H. L.; LIMA J. E. F. W.; FERRIGO S. Aplicação de série temporal mínima para simulação de vazões em bacia experimental do Cerrado. Revista Brasileira de Cartografia, n 68/8, p. 1497-1513, 2016.

CETESB. Significado ambiental e sanitário das variáveis de qualidade da água e dos sedimentos e metodologias analíticas e de amostragem. São Paulo: Secretaria do Meio Ambiente, 2009.

CONSELHO NACIONAL DO MEIO AMBIENTE (Brasil). Resolução n ${ }^{\circ}$ 357, de 17 de março de 2005. Diário Oficial [da] União, Seção 1, p. 58-63, Brasília, DF, 18 Mar. 2005.

COSTA, F. B.; FERREIRA, V. O. Análise de Parâmetros que Compõem o Índice de Qualidade das Águas (IQA) na Porção Mineira da Bacia do Rio Paranaíba. Revista Eletrônica de Geografia, v. 7, n. 18, p. 22-47, 2015.

DI BERNARDO, L.; DANTAS, A. D. B. Métodos e técnicas de tratamento de água. São Carlos: RiMa, 2005. v. 2, 1565 p.

FERREIRA, C. S. Avaliação temporal do uso e ocupação das terras na bacia do Rio São Bartolomeu, DF. 2006. 115p. Dissertação (Mestrado) - Faculdade de Agronomia e Medicina Veterinária, Universidade de Brasília, Brasília, 2006. 
HAIR, J. J. F.; ANDERSON, R. E.; TATHAM, R. L.; BLACK, W. C. Análise multivariada de dados. 6. ed. Porto Alegre: Bookman, 2009. 593p.

IBGE. Diretoria de Pesquisas, Coordenação de População e Indicadores Sociais. Estimativas da população residente com data de referência 1 de julho de 2017. Available at: https://cidades.ibge.gov.br/brasil/df/panorama. Access: 2017.

INPE. Divisão de processamento de imagens - DPI. Available at: http://www.dpi.inpe.br/ Aceess: 2018.

JOLLIFFE, L.T. Principal component analysis. 2. ed. New York: Springer, 2002. 487p.

KAISER, H. F. The varimax criteria for analitical rotation in factor analysis. Psychometrica, v. 23, p. 187-200, 1958.

LATTIN, J.; CARROL, J. D.; GREEN, P. E. Análise de dados multivariados. 1. ed. [S.l.]: Cengage Learning, 2011.

LE, S.; JOSSE, J.; HUSSON, F. FactoMineR: An R Package for Multivariate Analysis. Journal of Statistical Software, v. 25, n. 1, p. 1-18, 2008.

LEMOS, W. E. D. Monitoramento e gestão da qualidade da água em reservatórios incorporando processos hidrodinâmicos e climáticos de regiões tropicais semiáridas. 2011. 164 f. Dissertação (Mestrado) - Universidade Federal do Ceará, Fortaleza, 2011.

LIMA, J. E. F. W. Modelagem numérica do fluxo da água no solo e do escoamento de base em uma bacia experimental em área agrícola no Cerrado. 2010. 312p. Tese (Doutorado em Tecnologia Ambiental e Recursos Hídricos) - Universidade de Brasília, Brasília, 2010.

LIU, C. W.; LIM, K. H.; KUO, Y. M. Application of factor analysis in the assessment of groundwater quality in a Blackfoot disease area in Taiwan. Science of the Total Environment, v. 313, p. 77-89, 2003. https://doi.org/10.1016/S0048-9697(02)00683-6

MEDEIROS, A. C.; LIMA, M. O.; GIMARÃES, R. M. Avaliação da qualidade da água de consumo por comunidades ribeirinhas em áreas de exposição a poluentes urbanos e industriais nos municípios de Abaetetuba e Barcarena no estado do Pará, Brasil. Ciência e saúde coletiva, v. 21, p. 695-705, 2016. https://doi.org/10.1590/141381232015213.26572015

MUNIZ, D. H. F.; MORAES, A. S.; FREIRE, I. S.; CRUZ, C. J. D.; LIMA, J. E. F. W.; OLIVEIRA-FILHO, E. C. Evaluation of water quality parameters for monitoring natural, urban, and agricultural areas in the Brazilian Cerrado. Acta Limnologica Brasiliensia, v. 23, p. 307-317. 2011. http://dx.doi.org/10.1590/S2179-975X2012005000009

OKSANEN, J.; BLANCHET, F. G.; FRIENDLY, M.; KINDT, R.; LEGENDRE, P.; MCGLINN, D.; MINCHIN, P. R.; O'HARA, R. B.; SIMPSON, G. L.; SOLYMOS, P.; STEVENS, M. H. H.; SZOECS, E.; WAGNER, H. Vegan: Community Ecology Package. $\mathrm{R}$ package version 2.4-5. Available at: https://CRAN.Rproject.org/package=vegan. Access: 2017.

OLIVEIRA-FILHO, E. C.; CAIXETA, N. R.; SIMPLICIO, N. C. S.; SOUSA, S. R.; ARAGÃO, T. P.; MUNIZ, D. H. F. Implications of water hardness in ecotoxicological assessments for water quality regulatory purposes: a case study with the aquatic snail Biomphalaria glabrata (Say, 1818). Brazilian Journal of Biology, v. 74, p. 175-180. 2014. http://dx.doi.org/10.1590/1519-6984.24212 
OLIVEIRA-FILHO, E. C.; PARRON, L. M. Avaliação de qualidade das águas no Brasil: O Rio Preto examinado. Espaço \& Geografia, v. 8, p. 71-86, 2007.

PARRON, L. M.; MUNIZ, D. H. F.; PEREIRA, C. M. Manual de amostragem e análise físico-química de água. Colombo: Embrapa Florestas, 2011.

PASSOS, A. L. L; MUNIZ, D. H. F.; OLIVEIRA-FILHO, E. C. Critérios para Avaliação da Qualidade de Água no Brasil: Um Questionamento sobre os Parâmetros Utilizados. Fronteiras: Journal of Social, Technological and Environmental Science, v. 7, n. 2, p. 290-303, 2018.

PIRES, N. L.; MUNIZ, D. H. F.; KISAKA, K.; SIMPLICIO, N. C. S.; BORTOLUZZI, L.; LIMA, J. E. F. W.; OLIVEIRA-FILHO, E. C. Impacts of the urbanization process on water quality of Brazilian savanna rivers: the case of Preto River in Formosa, Goiás State, Brazil. International Journal of Environmental Research and Public Health, v. 12, p. 10671-10686, 2015. https://doi.org/10.3390/ijerph120910671

R CORE TEAM. R: A language and environment for statistical computing. Vienna: $R$ Foundation for Statistical Computing, 2017. Available at: https://www.R-project.org/. Access: 2017.

SAAD, A. R.; SEMENSATTO JR., D. L.; AYRES, F. M.; OLIVEIRA, P. E. Índice de qualidade da água - IQA do reservatório do tanque grande, município de Guarulhos, estado de São Paulo, Brasil: 1990-2006. Revista UnG - Geociências, v. 6, n. 1, p. 118133, 2007.

SENA-SOUZA, J. P.; MARTINS, E. S.; COUTO JUNIOR, A. F.; REATTO, A.; VASCONCELOS, V.; GOMES, M. P.; CARVALHO JUNIOR, O. A.; REIS, A. M. Mapeamento Geomorfológico da Bacia Hidrográfica do Rio São Bartolomeu, escala 1:100,000. Boletim de Pesquisa e Desenvolvimento, v. 314, 39p, 2013.

SIMEONOV, V.; STRATIS, J. A.; SAMARA, C.; ZACHARIADIS, G.; VOUTSA, D.; ANTHEMIDIS, A.; SOFONIOU, M.; KOUIMTZIS, T. Assessment of the surface water quality in Northern Greece. Water Research, v. 37, p. 4119-4124, 2003.

SILVA, A. M.; ROSA, A. H.; ANTUNES, F. M.; NOGUEIRA, D. P; LESSA, S. S. Relationship between water quality and land use along a stretch of the Sorocaba river (SP). Journal of the Brazilian Society of Ecotoxicology, v. 4, p. 65-71. 2009.

SILVA, G. C; BRINGEL, J. M. M. Incidência de coliformes totais e Escherichia coli nas águas utilizadas para irrigação pela comunidade do município de paço do lumiar- MA. Revista Brasileira de Agroecologia, v. 2, p. 599-603, 2007.

VIEIRA, C. H. N.; MATTOS, L. M.; MALAQUIAS, J. V.; AQUINO, F. G.; MARTINS, P. T. A. Spatial and temporal land use and land cover of the Upper Jardim River Basin, Distrito Federal, Brazil. Revista Brasileira de Geografia Física, v. 11, n. 1, p. 085-098, 2018.

WANICK, R. C; MACEDO-SOARES, P. H. M; MACHADO, A. C; BRITTO, F. G. A; MURTA, A. L. S; FREITAS, M. A. V. Avaliação do IQA como ferramenta de avaliação da qualidade de água nos corpos hídricos interceptados pela rodovia BR-163 (Guaratã do Norte - MT). In: SIMPÓSIO BRASILEIRO DE RECURSOS HÍDRICOS, 19., 2011, Maceió. Anais[...] São Paulo: ABAS, 2011.

WHO. Chemical hazards in drinking-water. 2017. Available at: http://www.who.int/water_sanitation_health/dwq/chemicals/en/. Access: 2017. 
ZAGATTO, P.A., LORENZETTI, M.L., LAMPARELLI, M.C., SALVADOR, M.E.P., MENEGON JR, N., BERTOLETTI, E. Aperfeiçoamento de um índice de qualidade de águas. Acta Limnologica Brasiliensia, Rio Claro, v. 11, p. 111-126, 1999.

ZOBY, J. L. G.; DUARTE, U. Caracterização Hidrogeológica da Bacia do Ribeirão Sobradinho - Brasília (DF). Geologia USP Série Científica, v. 1, p. 79-99, 2001. 


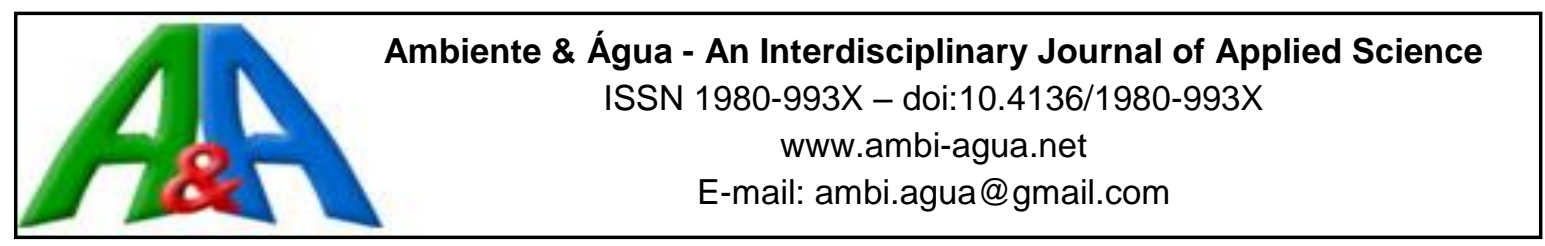

\title{
Analysis of the effect of impermeability of urban soils on the infiltration of rainwater in the city of Recife, $\mathrm{PE}$
}

\author{
ARTICLES doi:10.4136/ambi-agua.2386
}

Received: 25 Feb. 2019; Accepted: 10 Jun. 2019

\author{
Marco Aurelio Calixto Ribeiro de Holanda*iD; Willames de Albuquerque Soares \\ Universidade de Pernambuco (UPE), Recife, PE, Brasil \\ Escola Politécnica de Pernambuco (POLI). \\ E-mail: holandamacr@yahoo.com.br,was@poli.br \\ *Corresponding author
}

\begin{abstract}
The process of urbanization interferes in the elements of the hydrological cycle, altering the infiltration, flow, and evaporation of rainwater. Several methods and tests exist for analyzing this hydrological cycle that aim to hydrodynamically characterize the soil of a locality. However, the collection and field trials can be expensive and time consuming. Because of these high costs, it is important to look for methods that save time and money. One such method is to perform simulations of water flow in the soil, using computational models such as Hydrus 1-D, in order to explain the water balance of a region. The results of these simulations showed that $355.18 \mathrm{~mm} . \mathrm{m}^{-2}$ of the total $385.02 \mathrm{~mm} . \mathrm{m}^{-2}$ of precipitation was able to infiltrate, indicating that the soil of the region has a high infiltration capacity, due to its high sand content. However, of the $228,000 \mathrm{~m}^{2}$ studied, only $38,760 \mathrm{~m}^{2}$ are unpaved soil. This shows that the soil at the location studied would be able to infiltrate most rainwater without the occurrence of flooding, if more than only $17 \%$ of the land area were permeable soil. This conclusion can be extrapolated to other areas surrounding this neighborhood and to other large urban centers, which have similar characteristics.
\end{abstract}

Keywords: Hydrus-1D, infiltrability, soil hydrodynamics.

\section{Análise do efeito da impermeabilização dos solos urbanos na infiltração de água pluvial na cidade de Recife-PE}

\section{RESUMO}

O processo de urbanização interfere nos elementos do ciclo hidrológico, alterando as características de infiltração, escoamento e evaporação da água oriunda da chuva. Para analisar este ciclo hidrológico há diversos métodos e ensaios que visam caracterizar hidrodinamicamente o solo de uma localidade. Entretanto, a realização de coletas e ensaios de campo são onerosos e morosos. Por conta destes altos custos, é importante buscar métodos que visem economizar tempo e dinheiro. Uma das maneiras, é realizar simulações do fluxo de água no solo, mediante o uso de modelos computacionais como o Hydrus 1-D, afim de explicar o balanço hídrico de uma região. Os resultados dessas simulações apontaram que dos $385.02 \mathrm{~mm}$ que precipitaram $355.18 \mathrm{~mm}$ infiltraram, mostrando que o solo da região possui uma grande capacidade de infiltração, o qual é composto majoritariamente por areia, entretanto, dos 
$228000 \mathrm{~m}^{2}$ estudados apenas $38760 \mathrm{~m}^{2}$ são de solo não pavimentado. Estes resultados mostram que o solo do local estudado seria capaz de infiltrar a água pluvial sem gerar alagamentos, caso não houvesse apenas $17 \%$ de solo não impermeabilizado. Além disso, esta conclusão pode ser extrapolada para as áreas que circundam este bairro e também para grandes centros urbanos, uma vez que eles possuem características semelhantes.

Palavras-chave: dinâmica da água no solo, Hydrus-1D, infiltrabilidade.

\section{INTRODUCTION}

Water is a natural resource of great relevance to anthropic activities in many areas. Its cycle is indispensable for the maintenance of the passive balance between urbanization and nature. The processes that make up the hydrological cycle, from infiltration to evapotranspiration to surface runoff, are dependent on the physical environment in which they are found (Tucci, 2007).

The urbanization process interferes with the elements of this hydrological cycle, modifying the environment through deforestation, degradation of natural areas, as well as other damages, such as impermeabilization of the soil, lack of an ideal urban drainage system, and pollution of the catchment and outflow network, all related to the growth of population (Corte, 2015).

Soil is a vital part of the environment. It influences the distribution of plant species and provides a habitat for a large number of organisms. It also functions as a filtration system between the atmosphere and the earth for surface water and chemicals. Soil is relevant to the destiny of society because of the goods, resources, and services that it provides to humanity (Soares, 2018).

The water inside the soil exerts forces that influence the state of tension of the soil, modifying its stability, among other pertinent edaphic attributes (Carvalho and Almeida, 2018). Moisture has a great influence on the physical behavior of the soil, especially with regard to the dynamics of water caused by external agents, such as rain. The greatest interactions occur in the topmost surface layers of the soil, where the highest water flow rates can be observed in two directions: descending (infiltration) and ascending (evaporation). Beyond these vertical movements of water, the accumulation of water on the surface can also occur when the precipitation rate is greater than the infiltration rate. When this happens, water will pool on the surface of the soil, possibly giving rise to surface runoff (Simůnek et al., 2013).

With urbanization, the consequent impermeabilization of the soil is a current and recurrent problem for aquifers and groundwater sources, especially in large urban centers, because the water supply comes from water that infiltrates from the surface into the lower layers of the soil. There is great variability in the amount of time it takes for this process to occur completely, from days up to years (Cavalcanti, 2013).

According to Tucci (2004), a large urban concentration is considered to be a problem that favors flooding because of the improper use of land and the occupation of space, as well as through the insufficient management of urban drainage. Lack of planning and undue land occupation in the metropolitan area of Recife, together with high rainfall levels and variations in high tide, cause numerous floods.

There are many methods and tests that can be used to hydrodynamically characterize the soil of a locality. Because field experiments and laboratories are expensive and timeconsuming, many researchers have used numerical and analytical methods that make it possible to characterize the soil with great efficiency (Martinez and Silva, 2010). Zeng et al. (2018) used software to simulate a variety of possible events, obtaining results that match closely with reality.

Researchers like Mujovo (2014) have used computational models, such as Hydrus-1D, to 
perform hydrodynamic characterization of soils in urban areas, in order to control urban drainage by simulating infiltration trench models. This model has proven to be an excellent tool in decision making for drainage control techniques.

The use of these computational models has already become a reality in the scientific environment, because beyond modeling and predicting the objects of study accurately and precisely, they also save time and financial resources. This study estimated the water infiltration capacity of the soil using computational modeling of water flow by computational models such as Hydrus 1-D in a central and representative region of the city of Recife, the Madalena district, with data parameters of precipitation, insolation, and soil granulometry.

\section{MATERIALS AND METHODS}

The study area, in the Madalena neighborhood, is one of the main corridors connecting downtown Recife with the suburbs, through which can be accessed places such as the Federal University of Pernambuco and the Integrated Passenger Terminal. In addition, it contains several large shopping areas, hosts the Benfica campus of the University of Pernambuco and the Adelmar da Costa Carvalho football stadium. It also contains many residential units and some government offices.

The area shown in Figure 1, having approximately $228,000 \mathrm{~m}^{2}$, indicates the location studied containing the points where 27 samples were collected. In areas with natural soil cover, which make up $17 \%$ of the total study area, samples were collected for the purpose of laboratory tests. The points chosen were public squares, partially wooded and without large impermeabilized areas, as well as grassy areas with few trees making up part of the property of a local supermarket.

Much of this section of the Capibaribe River has a retaining wall separating the mangroves from the roads that border it. This wall was constructed to prevent the roads from being affected by the water during periods of high tide. Therefore, the physical properties of the superficial layers of the unpaved soil along the riverside are not influenced by the transport of fluvial sediments.

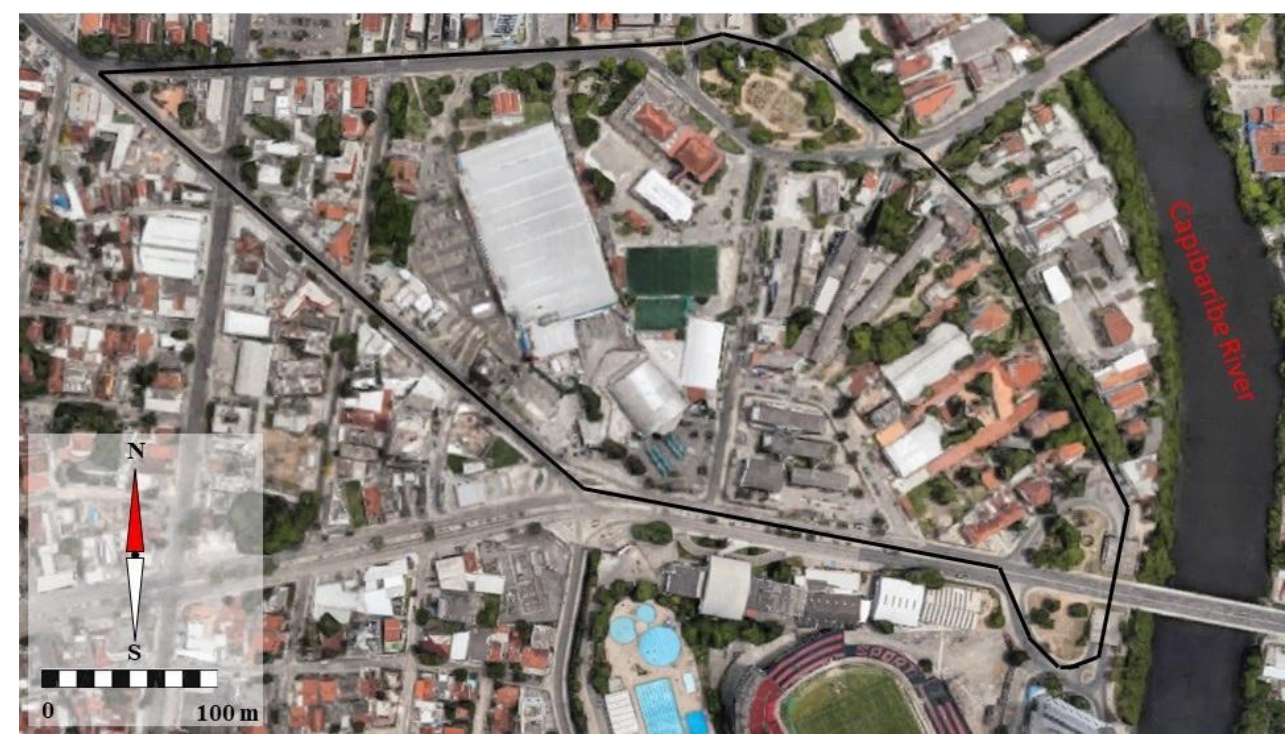

Figure 1. Area demarcated for study.

Most of the city of Recife is composed of flat relief (Silva, 2018). The delimited region varies gradually between 0 and $1 \mathrm{~m}$, with a small slope of $0.0025 \mathrm{~m} . \mathrm{m}^{-1}$. Therefore, the sediments present in the unpaved soil are not leached. 
Hydrus 1-D, used for modeling soil water dynamics, was constructed from a $300 \mathrm{~cm}$ deep layer, subdivided every $10 \mathrm{~cm}$ for contour conditions. The vegetation present at the collection sites was not considered in the simulations, because the crowns of the trees did not cover a large area and the root system was deep with no significant undergrowth along the ground. Urban drainage was also not considered in the simulations, because the absence of maintenance on the network present in this area has resulted in insufficiency of the drainage system.

The simulations were performed using version 4.17 of the HYDRUS-1D model (Simunek et al., 2013), which numerically solves the equation of one-dimensional water flow in porous media having variable saturation (Equation 1).

$\frac{\partial \theta}{\partial t}=\frac{\partial}{\partial z}\left(K \frac{\partial h}{\partial z}\right)$

Where $h$ is the matric potential, $t$ is the time, $z$ is the depth, and $K$ is the hydraulic conductivity of the soil.

In the simulation, the hydraulic model proposed by van Genuchten (1980) was used, where the soil water retention and hydraulic conductivity curves are expressed by Equations 2 and 3:

$$
\begin{aligned}
& \theta(h)=\theta_{r}+\frac{\theta_{s}-\theta_{r}}{\left(1+(\alpha h)^{n}\right)^{1-\frac{1}{n}}} \\
& K(\theta)=K_{s}\left(\frac{\theta-\theta_{s}}{\theta_{s}-\theta_{r}}\right)^{\frac{1}{2}}\left[1-\left(1-\left(\frac{\theta-\theta_{s}}{\theta_{s}-\theta_{r}}\right)^{\frac{1}{1-\frac{1}{n}}}\right)^{1-\frac{1}{n}}\right]^{2}
\end{aligned}
$$

Where $\theta_{r}$ and $\theta_{s}$ are the residual and saturated volumetric humidity, respectively, $\alpha$ and $n$ are the shape parameters, and $K_{s}$ is the saturated hydraulic conductivity. The values of $\theta_{r}, \theta_{s}$, $\alpha$, and $n$, which are required input values for the Hydrus 1D model, were obtained through the use of pedotransfer functions (PTFs), proposed by Barros et al. (2013), and the $K_{s}$ values were estimated using the proposal by Cosby et al. (1984). The values of these parameters are found using Equations 4, 5, 6, 7 and 8, shown below:

$$
\begin{aligned}
& \alpha=10^{0.93-1.60 G} \\
& n=1.53+0.33 A-0.39 G \\
& \theta_{r}=0.13-0.15 A+0.36 G \\
& \theta_{S}=0.55-0.23 A-0.12 G \\
& K_{S}=7.05556 \times 10^{-6} \times 10^{(-0.6+0.0126 A-0.0064 G)}
\end{aligned}
$$

These take into account the contribution of each component of the soil, where $A$ is the sand content $\left(\mathrm{kg} \mathrm{kg}^{-1}\right)$ and $G$ is the clay content $\left(\mathrm{kg} \mathrm{kg}^{-1}\right)$.

The soil granulometry was obtained using the NBR 7181 method (ABNT, 2016). This standard determines that the samples be sieved to separate the fractions of sand (with a diameter greater than or equal to $0.075 \mathrm{~mm}$ ) from the fractions of silt and clay (with diameter smaller than $0.075 \mathrm{~mm}$ ). This finer material must then be subjected to a sedimentation process, thereby obtaining the clay and silt quantities present in each of the 27 samples collected (Density Method).

To carry out the water simulation, the atmospheric parameters of wind speed, maximum and minimum temperatures, insolation time, precipitation, and relative humidity were used as contour conditions. The atmospheric data were obtained from the National Institute of 
Meteorology (INMET) database at the Curado station, where the meteorological station sensors are read and verified by an observer at predefined time intervals.

In order to estimate the daily reference evapotranspiration, the Penman-Monteith model was used, which is described by the FAO and makes use of input parameters such as precipitation, maximum and minimum temperatures, relative humidity, wind speed, and insolation time. In this case, the volume of accumulated precipitation (Figure 2A) was approximately $2264.8 \mathrm{~mm} . \mathrm{m}^{-2}$, with two major rains having values of $81.6 \mathrm{~mm}$ and $73.0 \mathrm{~mm}$, and an average rainfall of $5.72 \mathrm{~mm}$. Over the seven months analyzed, there were 63 days on which no precipitation occurred, with the period between January 1 and March 3 being the longest without any rainfall greater than $10 \mathrm{~mm}$.

The maximum and minimum temperatures (Figure 2B) were at their lowest levels during the months of greatest rainfall, that is, from May to July. It can also be observed that the periods with the greatest amount of sunlight, shown in Figure 2E, are during the months of January and February, which were the least rainy and had the lowest relative humidity (Figure 2D).

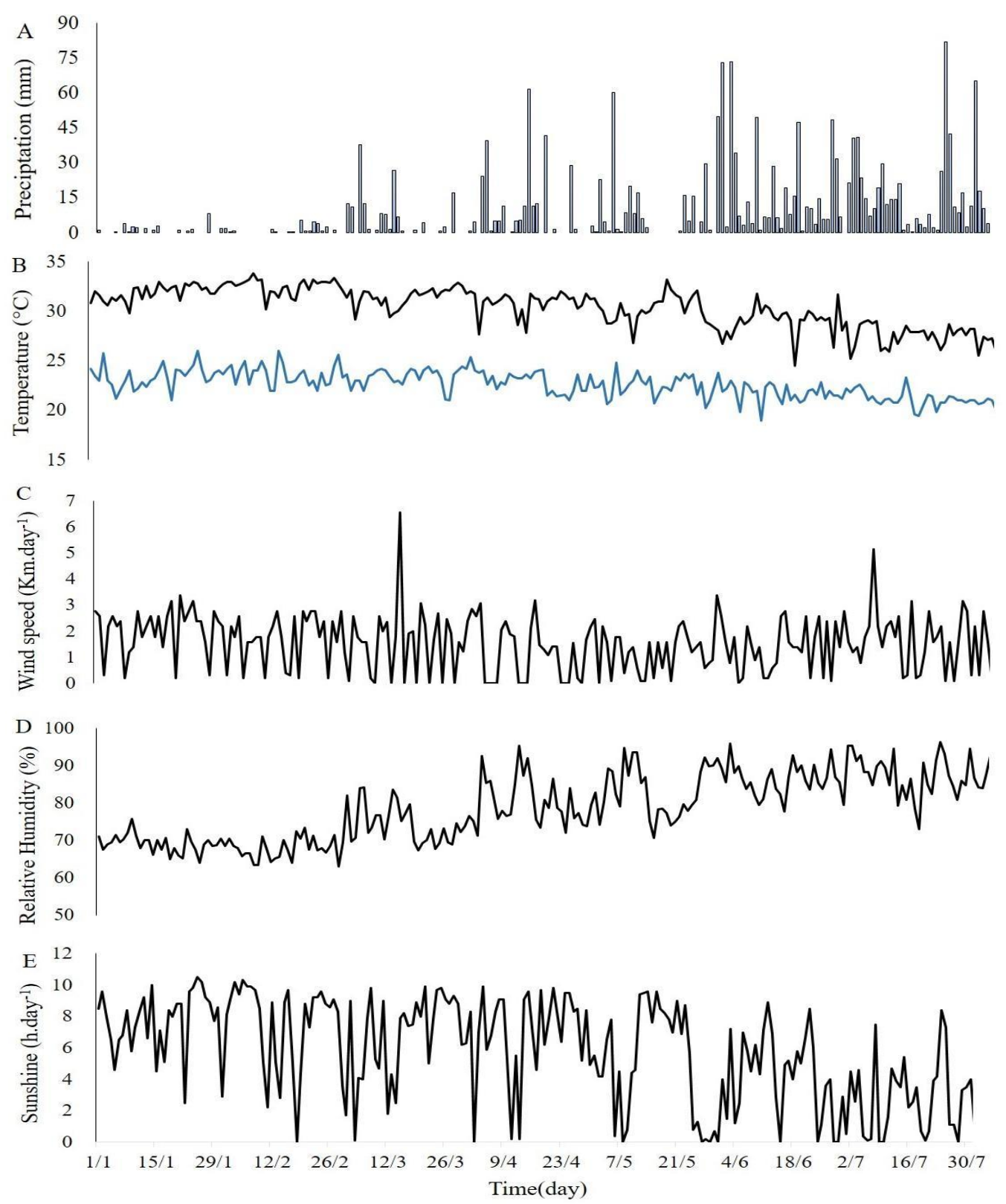

Figure 2. A accumulated rainfall values, $\mathbf{B}$ maximum (black) and minimum (blue) temperature, $\mathbf{C}$ wind speed, $\mathbf{D}$ relative humidity and $\mathbf{E}$ daily sunshine. 


\section{RESULTS AND DISCUSSION}

\subsection{Hydrodynamic Parameters}

Knowing the hydraulic conductivity or the infiltration capacity of the soil is very important because, according to the physical characteristics of each soil type, the infiltration of rainwater will be of different form and intensity, and this will affect the capacity of the soil to favor water percolation to the water table (Souza and Rodrigues, 2014).

According to Giachetti et al. (2000), soils with low or intermediate saturated hydraulic conductivity values may be clayey or silty, while sandy soils usually have high Ks values. The soil studied is characterized as being mostly sandy with a saturated hydraulic conductivity of

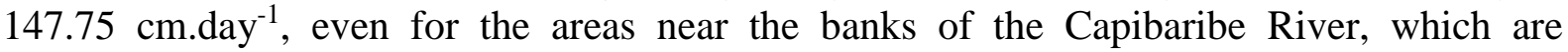
approximately $15 \mathrm{~m}$ away.

Another important factor to be considered in studies such as this is the composition of the soil, since, according to Oliveira et al. (2013), the water infiltration potential depends directly on the sand and clay content. In addition, they also stated that the rate of infiltration of water into clayey soils is usually lower than the rate of infiltration into sandy soils.

The soil studied was composed mainly of sand $(83.82 \%)$ with a small portion of clay $(3.83 \%)$ and the rest being silt (12.35\%). The values of $\alpha=0.0413 \mathrm{~cm}^{-1}, n=1.9446, \theta_{s}=$ $0.3857 \mathrm{~cm}^{3} \mathrm{~cm}^{-3}$, and $\theta_{r}=0.0408 \mathrm{~cm}^{3} \mathrm{~cm}^{-3}$ were obtained from the soil composition and used as necessary input values for the Hydrus 1D model simulation of soil water dynamics.

\subsection{Modeling}

During the period under study, from January to July 2017, the amount of water that infiltrated into the unpaved soil was approximately $355.18 \mathrm{~mm} \cdot \mathrm{m}^{-2}$, with near constant growth at some times of the year. The soil was found to have a high infiltration capacity, corroborating with the study by Coutinho (2011). However, due to the increasing amount of impermeabilized areas inherent to urbanization, which already cover $83 \%$ of the study area, the amount of water that can infiltrate into the soil has gradually diminished.

The rates of evaporation, infiltration, and runoff for the months of January to July 2017 originated from the simulations (Figure 3). In addition, these simulations also showed that, of the $385.02 \mathrm{~mm} . \mathrm{m}^{-2}$ that precipitated onto the $17 \%$ of unpaved soil during this period, 355.18 $\mathrm{mm} . \mathrm{m}^{-2}$ infiltrated and the rest either drained or evaporated, completing the area's water balance and showing the effectiveness of Hydrus-1D in modeling the water balance of the studied area.

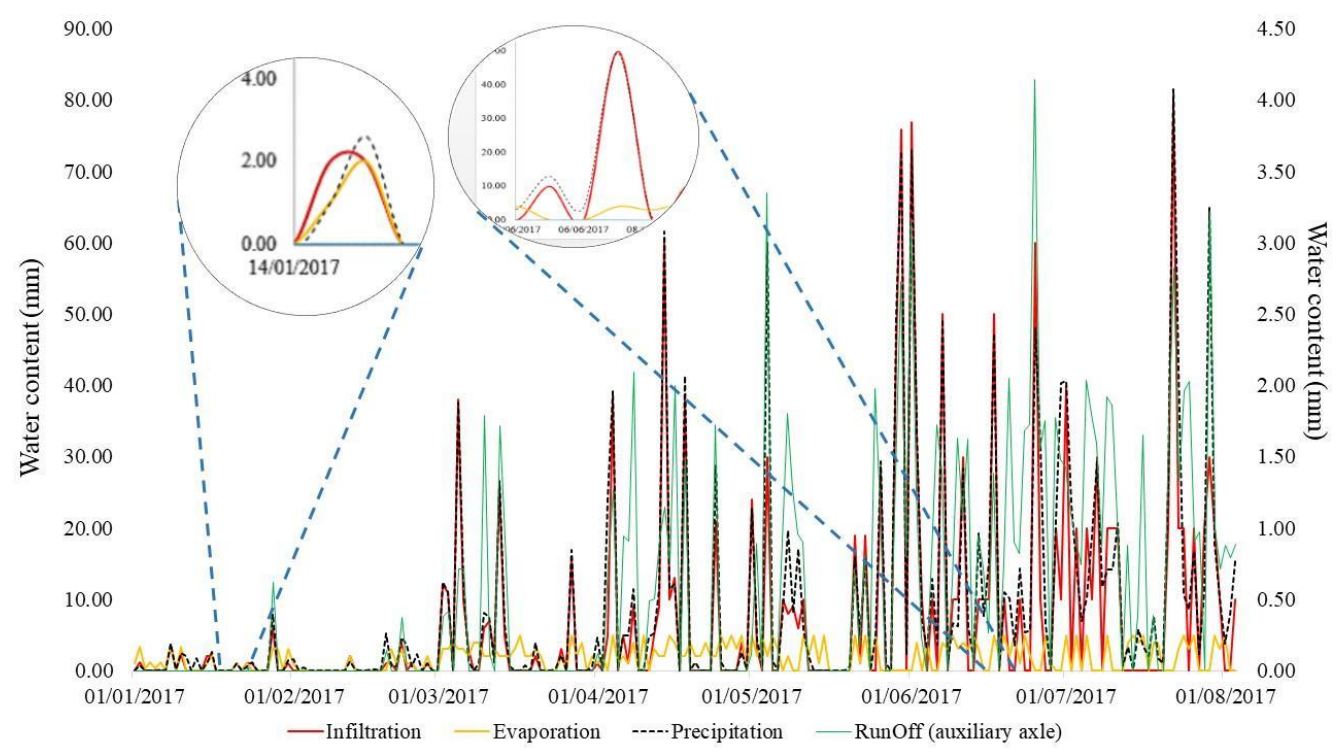

Figure 3. Water balance from January to July 2017 generated using Hydrus-1D.

Rev. Ambient. Água vol. 14 n. 4, e2386 - Taubaté 2019 
By comparing the rates of evaporation, infiltration, runoff and precipitation, it can be seen that, during the drier months of January and February, the evaporation curve (yellow) accompanies the precipitation curve (black). On January 14, for example, the water evaporation levels are consistent with precipitation levels. It is possible to observe that the rate of infiltration for this day is similar to the rates of evaporation and precipitation, but it reflects the accumulation of precipitation from the previous two days (Figure 3).

During the rainiest months, June and July, the infiltration curve (red) accompanies the precipitation curve (black). On June 6, for example, it can be observed that practically everything that infiltrated was related to the rain that fell on that day, while the amount of water that evaporates is related to the amount of water that did not infiltrate during the preceding days. Thus, it is possible to infer that if the paved area were smaller than its current $83 \%$, the locality would not suffer from constant flooding, because the soil present in the Madalena neighborhood allows for high rates of infiltration, agreeing with the study by Souza and Rodrigues (2014), which shows that soils with mostly sandy textures allow water to infiltrate more efficiently.

The month of July had the lowest evaporation rate during the period studied and it presented the highest precipitation values, more than $81 \mathrm{~mm}$, as can be observed in Figure 2A. This is due to the fact that, on the rainiest days, the amount of solar radiation reaching the surface is usually lower, which reduces the amount of evaporation taking place. It also needs to be taken into account that, in the wetter months, the relative humidity is higher, increasing the vapor pressure and reducing evapotranspiration rates. During the drier months of January and February, the highest evaporation rates were observed, approximately $6 \mathrm{~mm}^{\text {day }}{ }^{-1}$, as well as the highest temperatures $\left(36.8^{\circ} \mathrm{C}\right)$ and lowest rainfall rates (Figure $2 \mathrm{~B}$ ), in line with the results obtained by Ismael Filho et al. (2015).

Due to the heavy rainfall in the months of June and July, there is an increase in the amount of runoff because the few permeable areas saturate rapidly. In this case, in addition to rainfall, the presence of the Capibaribe River must be taken into account, which reduces the depth of the water table and consequently decreases the amount of water needed to saturate the permeable areas.

As its saturated hydraulic conductivity $K_{s}$ is $147.75 \mathrm{~cm} \mathrm{day}^{-1}$, the soil present in the Madalena neighborhood should be able to absorb all rainwater without generating significant flooding. However, as only $17 \%$ of the soil present in the locality is permeable, the scenario ends up reversed, with numerous floods occurring throughout the year, before even considering the interaction between the amount of residual water present in the soil and its infiltrability. It can therefore be said that in months where there is greater rainfall, as well as lower evapotranspiration rates and radiation balance, the Madalena neighborhood is susceptible to constant flooding, corroborating the study by Moreira (2014). That author goes even further in his analysis, noting that even following the construction of the Tapacura dam complex to control floods, poor occupation and use of soil in the region has intensified flooding events.

However, before the process of urbanization took place in Recife (or in the Madalena neighborhood), historical records from 1632 already indicated the occurrence of floods in the region (PE-AZ, 2011). The results obtained can be extrapolated to the areas surrounding the Madalena neighborhood, which make up the central zone of Recife, making it possible to explain flooding in other districts of the city, in addition to those in Madalena.

Just as in the Madalena neighborhood, where only $17 \%$ of the soil remains unpaved, other neighborhoods in the city of Recife (and in other large cities) also have few areas favorable to the drainage of rainwater. Many important neighborhoods of the city are therefore susceptible to flooding, especially in the months when the river level is higher and evaporation rates are lower. In addition to hampering access by residents, this flooding also disrupts the flow of through-traffic, considering the important avenues that cut through neighborhoods. 


\section{CONCLUSION}

The soil present in the unpaved areas has a high water infiltrability capacity, since the data obtained through the simulations show that $355.18 \mathrm{~mm} . \mathrm{m}^{-2}$ of the $385.02 \mathrm{~mm} . \mathrm{m}^{-2}$ total precipitation was infiltrated, or $92.25 \%$. This was expected due to the high sand content in its composition, containing $83.82 \%$ sand, $12.35 \%$ silt, and $3.83 \%$ clay. The remaining amount of water from this total precipitation either formed surface runoff or evaporated.

Flooding is more frequent during the months of June and July, which have the highest pluviometric indexes and the lowest sunshine indexes. Like the Madalena neighborhood, other localities also suffer from the same flooding problem inherent where there are high amounts of impermeable soil. If the impermeable area were not so high, $83 \%$, it would be difficult for the study area to suffer constant flooding, because the natural soil below the impermeable portion is sandy.

Compensatory urban drainage techniques, such as permeable pavement, infiltration trenches, rain gardens, green roofs, and retention and detention basins, have been proposed to assist the existing drainage system in minimizing flooding and in large urban centers. Some of these techniques are already being used in Recife, such as green roofs, which are mandatory and governed by Municipal Law 18.112/2015 (Recife, 2015).

\section{REFERENCES}

ABNT. NBR - 7181: Solo - Análise granulométrica. Rio de Janeiro, 2016. 16p.

BARROS, A. H. C.; LIER, Q. J. V.; MAIA, A. H. N.; SCARPARE, F. V. Pedotransfer Functions to Estimate Water Retention Parameters of Soils in Northeastern Brazil; Revista Brasileira de Ciências do Solo, v. 37, n. 2, p. 379-391, 2013. http://dx.doi.org/10.1590/S0100-06832013000200009

CARVALHO, W. M.; ALMEIDA, J. C. Patologias de edifícios históricos tombados estudo de caso: Convento das Mercês. In: CONFERÊNCIA SOBRE PATOLOGIA E RABILITAÇÃO DE EDIFÍCIOS, 6., 2018, Rio de janeiro. Proceedings[...]Rio de Janeiro: PATORREB: POLI-UERJ, 2018.

CAVALCANTI, H. F. Consequências da urbanização desordenada em área de nascente. Revista Didática Sistêmica, v .15, n. 1, 2013.

CORTE, A. C. D. Balanço hídrico em bacia urbana. 2015. 88p. Dissertation (Master's) Centro de Tecnologia - Universidade Federal de Santa Maria, Santa Maria, 2015.

COSBY, B. J.; HORNBERGER, G. M.; CLAPP, R. B.; GINN, T. R. A statistical exploration of the relationship of soil moisture characteristics to the physical properties of soils. Water Resources Research, v. 20, n. 6, p. 682-690, 1984.

COUTINHO, P. A. Pavimento permeável como técnica compensatória na drenagem urbana da cidade do Recife. 2011. 153 p. Dissertation (Master's) - Federal University of Pernambuco, Recife, 2011.

GENUCHTEN, M. T. Van. A closed-form equation for predicting the hydraulic conductivity of unsaturated soils. Soil Science Society of America Journal, v. 44, n. 3, p. 892-898, 1980. https://dx.doi.org/10.2136/sssaj1980.03615995004400050002x 
GIACHETTI, H. L.; FERREIRA, C. V.; LOBO, A. S.; MARQUES, M. E. M. A condutividade hidráulica de um solo arenoso determinada a partir de ensaios de campo e de laboratório. In: CONGRESO INTERAMERICANO DE INGENIERÍA SANITARIA Y AMBIENTAL, 27., Porto Alegre. Proceedings[...] Porto Alegre: ABES, 2000. p. 1-10.

ISMAEL FILHO, A.; BORGES, P. de F.; ARAÚJO, L. de S.; PEREIRA, A. R.; LIMA, E. M. de; SILVA, L. dos S.; SANTOS JUNIOR, C. V. dos. Influência das variáveis climáticas sobre a evapotranspiração. Gaia Scientia, v. 9, n.1, p. 62-66, 2015.

MARTINEZ, M. A.; SILVA, J. B. G. Modelagem do movimento de sais no solo. In: GHEYI, H. R.; DIAS, N. S.; LACERDA, C. F. DE. (Org.). Manejo de salinidade na agricultura: estudos básicos e aplicados. 1. Ed. Fortaleza: INCTsal, 2010. v. 1, p. 93-113.

MOREIRA, M. F. “Tapacurá estourou!": a vulnerabilidade da cidade anfíbia (Recife-PE) aos episódios de inundações e o bairro da Madalena. 2014. Thesis (Doctorate in Human Sciences) - Federal University of Santa Catarina, Florianópolis, 2014.

MUJOVO, M. J. N. Simulação de fluxo vertical em trincheiras de infiltração urbana. Dissertation (Master's) - University Federal de Santa Catarina, Florianópolis, 2014.

OLIVEIRA, N. S.; BARREIRA, R. Q.; BESSA, M. S. C.; PONTES, J. R. V.; SANTOS, C. L. Infiltração de água no solo arenoso e argiloso utilizando o método de anel simples no município de Conceição do Araguaia - PA. In: CONGRESSO BRASILEIRO DE GESTÃO AMBIENTAL: gestão ambiental e sustentabilidade, 4., 2013, Salvador. Proceedings[...] Salvador: IBEAS, 2013.

PE-AZ. Enchentes. $2011 . \quad$ Recife, Available at: http://www.peaz.com.br/index.php?option=com_content\&view=article\&id=1400:enche ntes \&catid =15\&Itemid=173. Accessed on: 26 Dec. 2018.

RECIFE. Lei $\mathrm{n}^{\mathrm{o}}$ 18.112/2015. Dispõe sobre a melhoria da qualidade ambiental das edificações por meio da obrigatoriedade de instalação do "telhado verde", e construção de reservatórios de acúmulo ou de retardo do escoamento das águas pluviais para a rede de drenagem e dá outras providências. Diário Oficial, Recife, 12 jan. 2015.

SILVA, A. C. Modelagem hidrológica-hidráulica para atenuação de alagamentos no entorno da Escola Politécnica de Pernambuco. 2018. Dissertation (Master's) University of Pernambuco, 2018.

SIMU゚NEK, J.; SEJNA, M.; SAITO, H.; SAKAI, M.; van GENUCHTEN, M. Th. The HYDRUS-1D Software Package for Simulating the One-Dimensional Movement of Water, Heat, and Multiple Solutes in Variably-Saturated Media. Riverside: University of California Riverside, 2013. v. 1, p. 1-308.

SOARES, W. de A. Impact of spineless cactus cultivation (O. ficus-indica) on the thermal characteristics of soil. Revista Ambiente \& Água, v. 13, n. 1, p. 1-13. 2018. http://dx.doi.org/10.4136/ambi-agua.2148

SOUZA, F. A.; RODRIGUES, S. C. Estimativa de recarga do lençol freático em solos sobre granito e gabros alcalinos na alta bacia do rio dos Boise m Iporá - GO. Ambiência, v. 10, n. 2, p. 499-463, 2014. https://dx.doi.org/10.5216/revgeoamb.v0i25.35332

TUCCI, C. E. M. Gerenciamento integrado das inundações urbanas no Brasil. Revista de Gestão de Água da América Latina, v. 1, n. 1, p. 59-73, 2004. http://dx.doi.org/10.21168/rega.v1n1.p59-73 
TUCCI, C. E. M. Hidrologia: ciência e aplicação. Porto Alegre, ABRH, 2007. 944p.

ZENG, W.; LEI, G.; ZHA, Y.; FANG, Y.; WU, J.; HUANG, J. Sensitivity and uncertainty analysis of the HYDRUS-1D model for root water uptake in saline soils. Crop and Pasture Science. v. 69, n. 2, p. 163-173, 2018. https://dx.doi.org/10.1071/CP17020 


Ambiente \& Água - An Interdisciplinary Journal of Applied Science
ISSN 1980-993X - doi:10.4136/1980-993X
www.ambi-agua.net
E-mail: ambi.agua@gmail.com

\title{
Post-treatment of landfill leachate using rice husk ash as adsorbent medium
}

\author{
ARTICLES doi:10.4136/ambi-agua.2350
}

Received: 27 Nov. 2018; Accepted: 29 Apr. 2019

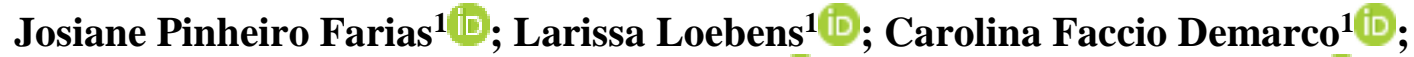 \\ Tito Roberto Sant'Anna Cadaval Junior ${ }^{2}{ }^{\mathbb{D}}$; Maurizio Silveira Quadro ${ }^{1}$; \\ Robson Andreazza ${ }^{*}$ (D)
${ }^{1}$ Universidade Federal de Pelotas (UFPEL), Pelotas, RS, Brasil
Centro de Engenharias (CEng). E-mail: jo.anetst@yahoo.com.br, laryloebens2012@gmail.com, carol_demarco@hotmail.com, mausq@hotmail.com,robsonandreazza@yahoo.com.br
${ }^{2}$ Universidade Federal do Rio Grande (FURG), Rio Grande, RS, Brasil
Escola de Química e Alimentos (EQA). E-mail: titoeq@ gmail.com
"Corresponding author

\begin{abstract}
Sanitary landfill is the most disposal method for urban solid waste. However, in the process of organic matter degradation, a dark-colored liquid with high potential for polluting is produced, necessitating an efficient treatment before its discharge into watercourses. Several technologies can be used in the treatment, such as biological and physico-chemical systems. The activated carbon produced from agricultural residues - rice husk ash (RHA), appears as an alternative treatment, mainly for color reduction in landfill leachate. This study determined the best operational condition for the slurry treatment using a fixed-bed column. The column was filled with activated RHA and support material (sand). The column heights studied were $5 \mathrm{~cm}$ (C1) and $20 \mathrm{~cm}$ (C2) of adsorbent. The column with $20 \mathrm{~cm}$ of RHA and sand intercalated with the coal layer showed better efficiency in removal of the chemical oxygen demand (COD), with COD removal efficiency of $88.91 \%$ and rupture time of $120 \mathrm{~min}$. The removal of apparent color was $87.40 \%$ with the rupture time of $40 \mathrm{~min}$ and true color removal of $86.64 \%$ with rupture time of $50 \mathrm{~min}$. Activated rice husk ash was shown to be promising for post-treatment of the leachate with substantial efficiency.
\end{abstract}

Keywords: agricultural waste reuse, basic activation, fixed-bed column.

\section{Pós tratamento de lixiviado de aterro sanitário utilizando cinza de casca de arroz como meio adsorvente}

\section{RESUMO}

O aterro sanitário é o método mais geral de disposição de resíduos sólidos urbanos. Porém, no processo de degradação da matéria orgânica é produzido um líquido de coloração escura de alto potencial poluente sendo necessário tratamento adequado antes de seu lançamento nos corpos de água. Diversas tecnologias podem ser utilizadas no tratamento, como sistemas biológicos e método físico-químico. O carvão ativado produzido a partir de resíduos agrícolas, cinza de casca de arroz (CCA), surge como alternativa para o tratamento, principalmente para a redução de cor em lixiviados de aterro. Este trabalho determinou a melhor condição 
operacional para o tratamento de chorume utilizando uma coluna de leito fixo. A coluna foi preenchida com CCA ativada e material suporte (areia). As alturas de coluna estudadas foram $5 \mathrm{~cm}(\mathrm{C} 1)$ e $20 \mathrm{~cm}$ (C2) de adsorvente. A coluna com $20 \mathrm{~cm}$ de CCA e areia intercalada com a camada de carvão apresentou melhor eficiência na remoção de carga orgânica (DQO), com eficiência de remoção de DQO de $88,91 \%$ e tempo ruptura de $120 \mathrm{~min}$. A remoção de cor aparente foi de $87,40 \%$ com tempo de ruptura de 40 min e a remoção a cor verdadeira de $86,64 \%$ com tempo de ruptura de $50 \mathrm{~min}$. A cinza de casca de arroz ativada mostrou-se promissora para pós tratamento de lixiviado com eficiência.

Palavras-chave: aproveitamento de resíduos agrícolas, ativação básica, coluna de leito fixo.

\section{INTRODUCTION}

Urbanization exploits natural resources and generates a large amount of Municipal Solid Waste (MSW). These wastes cause much environmental damage, and highlight the need for adequate treatment (Andrade and Ferreira, 2011). Among the most common techniques of treatment and final disposal of solid wastes are reduction, compaction, milling, animal feed, composting, anaerobic digestion, incineration, launching in sewage treatment systems and deposition in dumps and landfills. Among the techniques used, the landfill is an environmentally adequate disposal method commonly employed. However, leachate is formed from the percolation of rainwater through the the wastes, and it that carries pollutant compounds with high levels of ammoniacal nitrogen (NH3 and $\mathrm{N}$ ), biochemical oxygen demand (BOD5), oxygen demand (COD), color (humic substances), heavy metals and suspended solids (Mojiri et al., 2014).

Due to its characteristics, the release of leachate without proper treatment can lead to contamination of surface and groundwater. Slurry treatment is therefore essential. Many technologies can be used in the treatment, such as biological systems and physico-chemical methods. Among the technologies, activated carbon has been used to remove several pollutants from the effluents, and it presents high efficiency in the removal of non-biodegradable compounds from the leachate (Hosseini et al., 2015; Mojiri et al., 2014).

Some studies involving only the adsorption process combined with biological reactors showed good efficiency in the reduction of the recalcitrant organic matter, color and other contaminants present in the leachate (Anju and Kani, 2017; Kasman and Ibrahim, 2016; Mojiri et al., 2014). However, there are few studies using rice husk ash resulting from the boiler combustion process of the rice-processing companies, as well as the use of low-cost adsorbents in the treatment of real effluents.

Anju and Kani (2017) studied the removal of turbidity, oxygen demand and suspended solids from a landfill leachate using activated rice husk ash as adsorbent; however, the authors used rice husk as a previously washed precursor for the removal of impurities to subsequent carbonization and ash activation.

In this context, this study evaluated the use of activated rice husk ash as adsorbent product in a dynamic system for the post-treatment process of leachate from the landfill of the city of Candiota/RS, which receives wastes from 19 municipalities in the Southern region.

\section{MATERIALS AND METHODS}

The study was carried out at the Laboratory of Analysis of Water and Effluents, located at the Center of Engineering (CEng) of the Federal University of Pelotas (UFPel).

\subsection{Leachate characterization}

The leachate used was sampled from the landfill of the South Half at latitude $-31,56873500$ and longitude -53, 73099600 in the municipality of Candiota of the State of Rio Grande do Sul 
(RS). The effluent was collected by the technician responsible for the sanitary landfill in the last anaerobic lagoon and stored in a 25-liter container and sent to the Laboratory.

The effluent used in this study was characterized according to the parameters of Chemical Demand of Oxygen, pH, Apparent and True Color at the input and output of the fixed-bed system with active carbon of rice husk ash, according to the methodology described by APHA et al. (2005).

\subsection{Activated carbon used}

The activated carbon used was from rice husk ash (RHA) from a rice-processing industry located at Pelotas/RS. The company uses the rice husk for generating thermal energy, conducting the firing in a grid-type reactor at a temperature of $800^{\circ} \mathrm{C}$.

The activation of RHA was performed with sodium hydroxide as activating agent. In this process, $600 \mathrm{~g}$ of the raw material was separated, to which was added $600 \mathrm{~g}$ of sodium hydroxide dissolved in 2 liters of distilled water with a ratio of 1:1 ( NaOH/ash). The mixture was maintained in contact for 24 hours, then it was washed with distilled water in order to achieve neutrality and to remove the reagents and impurities. Afterwards, the materials were dried in an oven at $110^{\circ} \mathrm{C}$ for 24 hours.

The concentration of the activating agent was established based on the study by Muniandy et al. (2014) with a difference in impregnation time. The methodology chosen for the ashwashing process was based on the work of Le Van and Luong Thi (2014), who also produced activated carbon from rice husk ash.

\subsection{Characterization of pulverized activated carbon}

The physical characterization was performed using the methodologies described by the Brazilian Technical Standards Association (MB 3414/1991, MB 3413/1991 and MB 3412/ 1991). The main characteristics of activated carbon ash used in the test were: humidity of 2.37 $\pm 0.2 \%$, apparent specific mass of $0.25 \pm 0.004 \mathrm{~g} . \mathrm{cm}^{-3}$, methylene blue of $10,05 \pm 0,70 \mathrm{mg} \cdot \mathrm{g}^{-1}$ and granulometry (\% passing mass) of $38.8 \pm 2.35 \%, 80.2 \pm 1.64 \%$ and $97.4 \pm 0.05 \%$ in sieves of $\mathrm{n}^{\circ} 100, \mathrm{n}^{\circ} 200$ and $\mathrm{n}^{\circ} 325$, respectively.

The morphological and elemental composition of the precursor surface (RHA) and activated carbon was mapped with the Scanning Electron Microscopy (SEM) system coupled to an EDS system. The analyses were carried out using a scanning electron microscope (JEOL JSM 6610, Japan). The samples were metalized with gold. A $15 \mathrm{kV}$ voltage acceleration was used and magnification ranges from 50 to 2500 times. The morphology and elemental composition was carried out at the Laboratory of Unitary Operations of the Chemical Engineering Course of the Federal University of Rio Grande (FURG). The EDS spectrum for raw rice husk and activated carbon are shown in Figures 1 and 2.

A

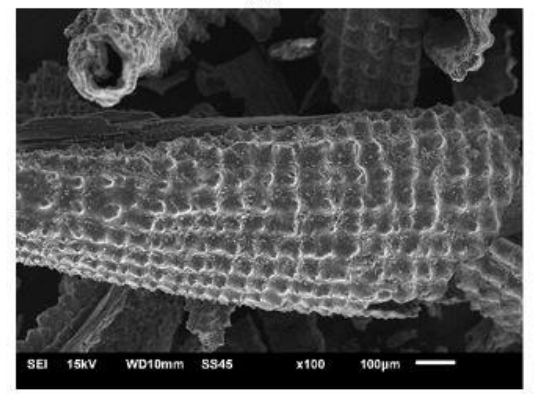

B

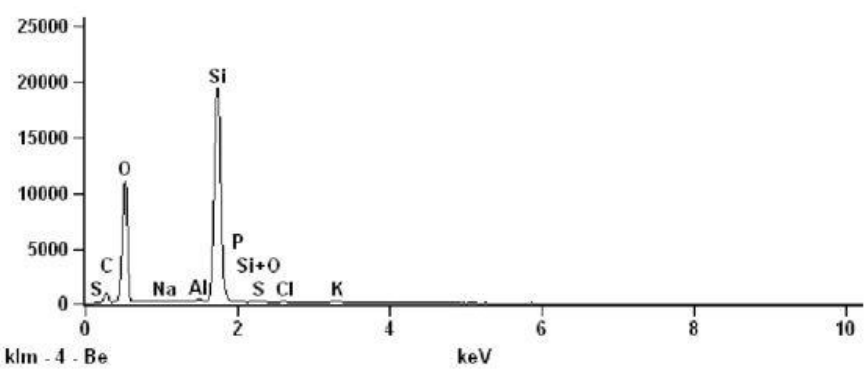

Figure 1. ESD spectrum for raw Rice Husk Ash (RHA). 

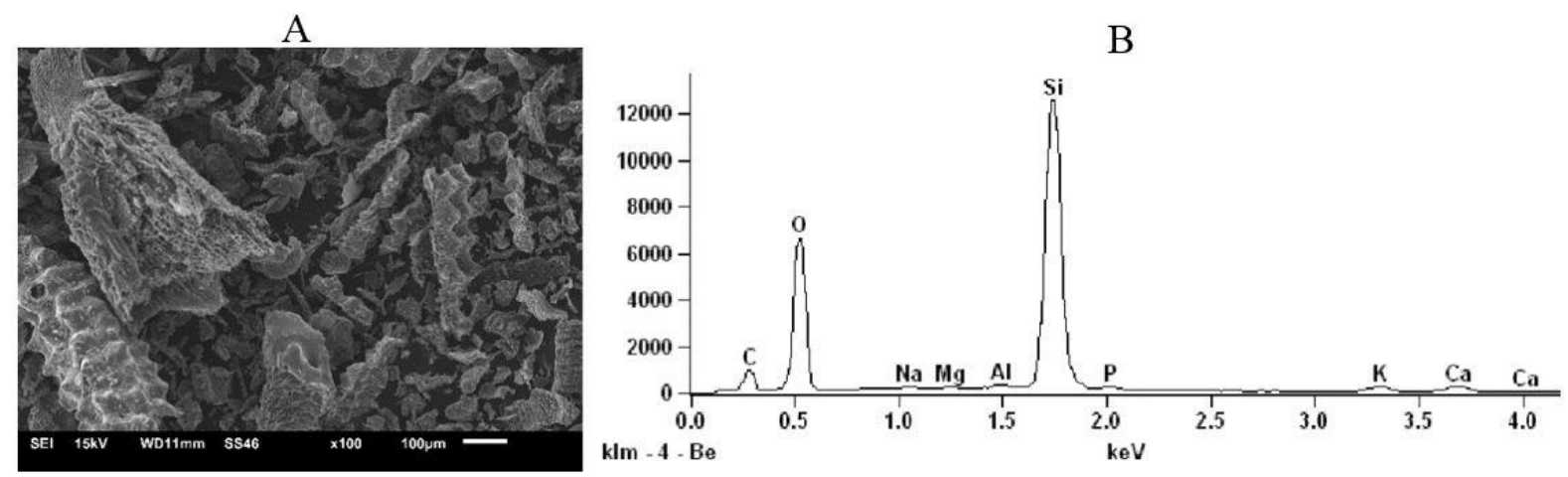

Figure 2. EDS spectrum for chemically activated carbon with $\mathrm{NaOH}$.

Figure 1A shows the formation of a material with a structure of interstices more evident, suggesting the appearance of the porous structure. From Figures $1 \mathrm{~B}$ and $2 \mathrm{~B}$, the majority of silicon and oxygen can be seen, still presenting in its composition sulfur, carbon, calcium, magnesium, sodium, aluminium, phosphorus, chlorine, silicon oxide and potassium.

\subsection{Adsorption Assays in Fixed-Bed Column}

For the down flow adsorption tests, a column of glass was adjusted with a length of $30 \mathrm{~cm}$, internal diameter of $5 \mathrm{~cm}$, and the flow was maintained by a prototype with a peristaltic pump developed at the laboratory.

Two tests were carried out in the column of activated carbon of rice husk ash called $\mathrm{C} 1$ and $\mathrm{C} 2$. The $\mathrm{C} 1$ test presented a bed height of $5 \mathrm{~cm}$ and $\mathrm{C} 2$ presented a bed height of $20 \mathrm{~cm}$, corresponding to adsorbent masses of 24 and 95 grams, respectively. The experiments were performed in triplicate for each treatment.

The system was placed the lower base of the column in wire screens, in order to retain particles which are eventually flow in the liquid and can obstruct or decrease the operating capacity of the system. A layer of sand was then placed over the screen, as a support layer for the adsorbent, whose particles were compacted with a little shaking. Subsequently, a layer of coal was introduced, which also was compacted. Finally, a layer of pebbles was added to the upper base to facilitate distribution of the flow through the adsorbent layer, thus minimizing the effects of forming preferred paths during its operation.

In the $20 \mathrm{~cm}$ bed height column, the sand was distributed in the base and in the core of the column, to act as a support and diffuser for liquid within the bed.

The beginning of the test occurred when the system was completely filled with the sample and the flow rate adjusted. Therefore, the first few minutes of effluent collection was discarded. Subsequently, samples were taken at intervals of 10, 20, 30, 40, 50, 60, 90, 120, 150, 180, 210 and 220 minutes, in order to evaluate the concentration at the output of the column. The analyzed parameters were COD and color. The effluent was repressed by a pump with a flow rate of $8 \mathrm{~mL} \cdot \mathrm{min}^{-1}$. All assays were performed at room temperature.

\subsection{Fixed-bed Column data analysis}

The adsorption capacity of the column was determined by the following Equation 1:

$q=\frac{C_{0} Q}{m_{s}} \int_{0}^{t}\left(1-\frac{c}{c o}\right) d t$

Being, $\mathrm{q}=$ the adsorption capacity of the adsorbent $\left(\mathrm{mg} \mathrm{g}^{-1}\right)$; Co = initial concentration of the fluid in the input $\left(\mathrm{mg} \mathrm{L}^{-1}\right) ; \mathrm{C}=$ concentration of the fluid at the output of the column $\left(\mathrm{mg} \mathrm{L}^{-1}\right)$; 
$\mathrm{Q}=$ volumetric flow rate of the solution $\left(\mathrm{L} \mathrm{min}^{-1}\right) ; \mathrm{t}=$ time $(\mathrm{min}) ; \mathrm{m}_{\mathrm{s}}=$ dry mass of the adsorbent (g).

Removal efficiency was calculated by the following Equation 2:

$\% R=\frac{\left(C_{o}-C\right)}{C_{0}} * 100$

Being, $\% \mathrm{R}=$ Removal percentage; $\mathrm{Co}=$ initial concentration of the fluid in the input $\left(\mathrm{mg} \mathrm{L}^{-1}\right) ; \mathrm{C}=$ concentration of the fluid at the output of the column $\left(\mathrm{mg} \mathrm{L}^{-1}\right)$.

The time of the Breakthrough was obtained by the curve inclination of the adsorbate concentration at the output of the bed, which consists of the ratio of $\mathrm{C} / \mathrm{C}_{0}$ against the time. The break point was considered from $\left(\mathrm{C} / \mathrm{C}_{0}\right) \geq 0.3$ for $\mathrm{C} 1$ and $\left(\mathrm{C} / \mathrm{C}_{0}\right) \geq 0.1$ for $\mathrm{C} 2$ and saturation point $\left(\mathrm{C} / \mathrm{C}_{\mathrm{o}}\right) \geq 0.8$ for $\mathrm{C} 1$ and $\mathrm{C} 2$. In practice, the industries work with a useful column volume, which means that the rupture and saturation time can be decided according to need or the output concentration can be equivalent to a reference value established by current legislation (Karunarathne and Amarasinghe, 2013). The performance of RHA activated at different bed heights was analyzed in the Statistica ${ }^{\circledR}$ program, Version 7.0. The parameters were adsorption capacity for the rupture and saturation times for the analysis of chemical oxygen demand; real and apparent color were performed with a completely randomized design and the results were treated by Analysis of Variance (ANOVA) and, when significant, the Fischer test was performed $(\mathrm{p}<0.05)$.

\section{RESULTS AND DISCUSSION}

The results were obtained by the curves considering the height of the bed of $5 \mathrm{~cm}(\mathrm{C} 1)$ and $20 \mathrm{~cm}(\mathrm{C} 2)$ and initial organic matter concentration of $4538.61 \pm 190.82 \mathrm{mg} . \mathrm{L}^{-1} \mathrm{COD}, \mathrm{pH} 8.14$ , apparent color of $176000 \pm 1885.62 \mathrm{UC}$ and true color of $16600 \pm 942.81 \mathrm{UC}$ (Figures 3 and 4). The parameters $t_{r}$ and $t_{s}$ were calculated (Table 1), along with the adsorption capacity, residual concentration of COD and color. The $t_{r}$ refers to the time of rupture or time required for the adsorbate to be detected at the exit of the bed and $t_{s}$ refers to the time required for bed exhaustion.

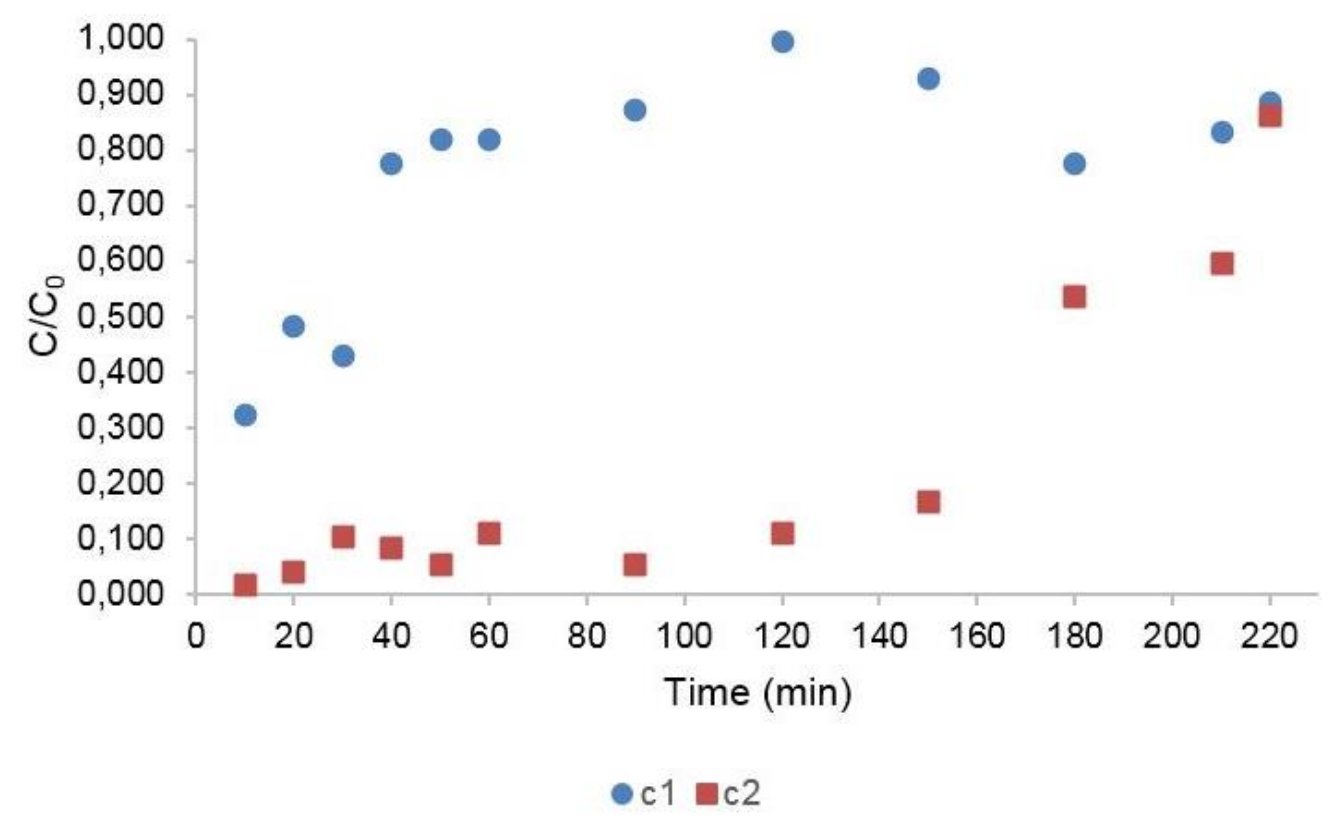

Figure 3. Rupture curves for $\mathrm{C} 1$ (bed height of $5 \mathrm{~cm}$ ) and $\mathrm{C} 2$ (bed height of $20 \mathrm{~cm}$ ) treatments for the removal of organic matter (COD). 


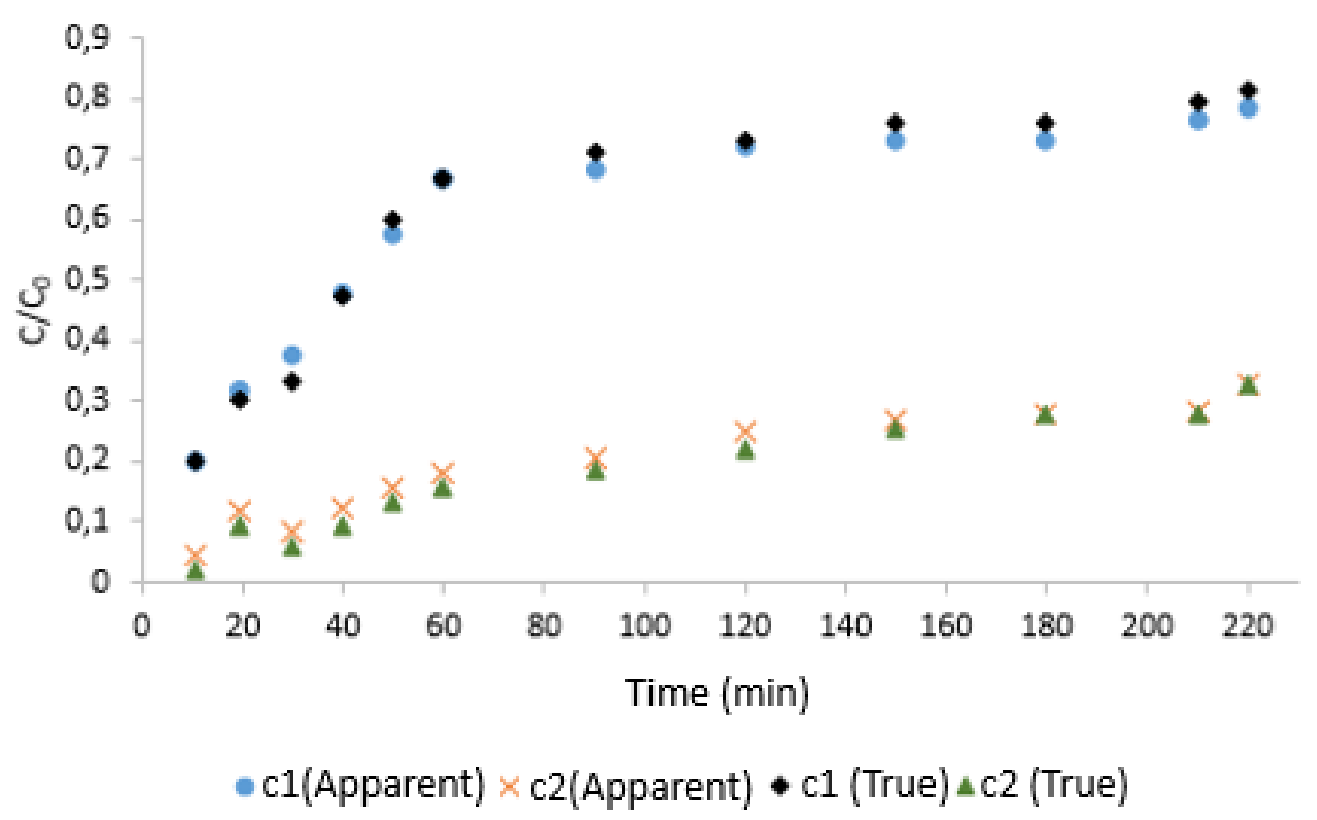

Figure 4. Rupture curves of apparent color and true color removal for $\mathrm{C} 1$ and $\mathrm{C} 2$.

Table 1. * Characteristics of the $\mathrm{C} 1$ and $\mathrm{C} 2$ tests for COD and apparent color removal.

\begin{tabular}{|c|c|c|c|c|c|c|}
\hline \multirow{2}{*}{ Parameters } & \multicolumn{2}{|c|}{ COD } & \multicolumn{2}{|c|}{ Apparent color } & \multicolumn{2}{|c|}{ True color } \\
\hline & $\mathrm{C} 1$ & $\mathrm{C} 2$ & $\mathrm{C} 1$ & $\mathrm{C} 2$ & $\mathrm{C} 1$ & $\mathrm{C} 2$ \\
\hline Bed Height (cm) & 5 & 20 & 5 & 20 & 5 & 20 \\
\hline Flow $\left(\mathrm{mL} \min ^{-1}\right)$ & 8 & 8 & 8 & 8 & 8 & 8 \\
\hline $\mathrm{t}_{\mathrm{r}}(\min )$ & 10 & 120 & 20 & 40 & 30 & 50 \\
\hline $\mathrm{q}_{\mathrm{r}}\left(\mathrm{mg} \mathrm{g}^{-1}\right)$ & $10,23^{\mathrm{a}}$ & $40,77^{\mathrm{ab}}$ & $79,77^{\text {acd }}$ & $54,81^{\mathrm{bc}}$ & $110,5^{\mathrm{d}}$ & $60,56^{\mathrm{bc}}$ \\
\hline **Parameters residual $\mathrm{r}_{\mathrm{r}}$ & 1467,89 & 503,145 & 5633,3 & 2216,67 & 5550 & 2216,7 \\
\hline $\mathrm{t}_{\mathrm{s}}(\min )$ & 40 & 220 & 210 & $220 * * *$ & 210 & $220 * * *$ \\
\hline $\mathrm{q}_{\mathrm{s}}\left(\mathrm{mg} \mathrm{g}^{-1}\right)$ & $13,55^{\mathrm{a}}$ & $11,57^{\mathrm{a}}$ & $289,33^{\mathrm{g}}$ & $220,15^{\mathrm{ef} * * *}$ & $242,67^{\mathrm{cf}}$ & $207,80^{\mathrm{e}} * * *$ \\
\hline$* *$ Parameters residual ${ }_{\mathrm{s}}$ & 3522,013 & 3914,37 & 13466,67 & $5716,67 * * *$ & 13133,33 & $5383,33 * * *$ \\
\hline
\end{tabular}

*Means followed by the same letter are not significantly different at the $95 \%$ confidence level (Fischer's test). **Parametres residual: Cod (mg. $\left.\mathrm{g}^{-1}\right)$; Color (UC). ***values obtained for the total operating time.

Figures 3 and 4 show that the increase in height of bed positively affected the efficiency of removal of organic load and leachate color, since the career time of the rupture of the $\mathrm{C} 2$ treatment was greater than that of the $\mathrm{C} 1$ (Table 1). The $\mathrm{C} 2$ treatment had shown a removal efficiency up to $86.64 \%$ of the true color, and $87.4 \%$ of the apparent color and $88.91 \%$ of the COD. On the other hand, the treatment $\mathrm{C} 1$ showed a efficiency for removal of $66.56 \%$ of the true color, $67.65 \%$ of the COD and $67.99 \%$ of the apparent color. These values are compatible with other study developed by Kawahigashi et al. (2014), in which authors verified the effectiveness of adsorption with commercial granular carbon of coconut endocarp as post treatment of landfill leachate, removing around 45 to $76 \%$ of COD, 95 to $100 \%$ of apparent color and 94 to 100 of the true color under conditions of $\mathrm{pH}=4.0, \mathrm{Fe}^{3+}$ dose $\left(\mathrm{mg} \mathrm{Fe}^{3+} . \mathrm{L}^{-1}\right)$, initial COD of $303 \mathrm{mg} . \mathrm{L}^{-1}$ and height of bed of $9 \mathrm{~cm}$.

Vieira (2014), in a similar study, found that with the increase of the height of the bed from $10 \mathrm{~cm}$ to $30 \mathrm{~cm}$, an improvement in performance was shown, increasing the rupture time and the percentage of removal at this condition. The best condition found in this study was $30 \mathrm{~cm}$ of the bed height, yellow tartrazine dye concentration of $50 \mathrm{mg} \mathrm{L}^{-1}$, rupture time of $88 \mathrm{~min}$, 
maximum column capacity of $108.0 \mathrm{mg} \mathrm{g}^{-1}$ and the removal percentage of $85.9 \%$, using the chitosan as adsorbent.

The behavior shown in our study corroborates with that found by Vieira (2014), with the variation of the bed height a factor with a great influence in the phenomenon of adsorption. In addition, the height of the bed, particle size, pore size, molecular weight and pollutant concentration are other parameters that altered the characteristics of the adsorption process.

Regarding the particle size, generally, materials with lower granulometry have a higher capacity for pollutant removal, i.e., adsorbent with particle size $0.297-0.841 \mathrm{~mm}$ results in 2 to 3 times greater capacity for removal than adsorbents with a particle size of $0.420^{-1} .680 \mathrm{~mm}$ (Tauma, 2013). Thus, it can be affirmed that the particle size of the activated charcoal of rice husk ash showed a great capacity of removal influence on the organic matter and color of the landfill leachate.

Methylene blue index is a technique used to indirectly measure the pore size of the adsorbents; the materials with high methylene blue index indicate that the material analyzed is mesoporous ( 2 to $50 \mathrm{~nm}$ ) (Kawahigashi et al., 2014). In this perspective, the activated carbon of RHA presents elusive indication of material with mesopores, according to the value of index of methylene blue found of $10.05 \mathrm{mg} \cdot \mathrm{g}^{-1}$. The presence of pores of the coal used in the study can be observed in the SEM image presented in Figure 2.

According to Castilhos Junior et al. (2010), one of the main constituents of the recalcitrant organic matter of the leachate are the humic substances and fulvic acids that are high molecular weight substances. These substances are responsible for the coloration of leachates (Queiroz et al., 2011). Thus, the high efficiency of the systems can be attributed to the large molecular weight of humic substances and fulvic acids that can easily be removed from the aqueous solution by adsorption through two effects: solubility and surface attraction. Also, the principle of destabilization due to particle collisions can be highlighted. This phenomenon occurs due to the high concentration of the contaminant in solution (Tauma, 2013), as shown in the characterization of the leachate with high staining, expressed as apparent and true color.

\section{CONCLUSION}

In summary, the study was satisfactory for the dynamic process of adsorption in a fixed bed. The study showed that the use of activated rice husk ash is a promising method for posttreatment of stabilized landfill leachate with regard to COD removal, apparent and true color. The experiment showed removal efficiency higher than $60 \%$ for the analyzed parameters.

The $20 \mathrm{~cm}$ of height of bed was the system that provided better performance and longer operation time in the leachate treatment. Further studies changing other parameters are highly recommended.

\section{ACKNOWLEDGEMENTS}

This study was financed in part by the Coordenação de Aperfeiçoamento de Pessoal de Nível Superior - Brasil (CAPES) - Finance Code 001, and Brazilian National Council for Scientific and Technological Development (CNPq) and Research Support Foundation of the State of Rio Grande do Sul (FAPERGS).

\section{REFERENCES}

ANJU, S.; KANI, K. M. Assessing the Effectiveness of Rice Husk Ash in Treating Municipal Leachate. International Journal of Emerging Technology and Advanced Engineering, v. 7, p. 42-54, 2017. 
APHA; AWWA; WEF. Standard Methods for the Examination of Water and Wastewater. 21. ed. Washington, 2005.

ANDRADE, R. M. de; FERREIRA, J. A. A gestão de resíduos sólidos urbanos no brasil frente às questões da globalização. Revista Eletrônica do Prodema, v. 6, n. 1, p. 7-22, 2011.

CASTILHOS JUNIOR, A. B.; DALSASSO, R. L.; ROHERS, F. Pré-tratamento de lixiviados de aterros sanitários por filtração direta ascendente e coluna de carvão ativado. Engenharia Sanitária e Ambiental, v. 15, n. 4, p. 385-392, 2010.

HOSSEINI, H. M. S.; KARIMI. R; NOVAIR. S. B.; TABATAHAEI. S. H. A study of treated municipal waste leachate and Zeolite effects on soils. Iran Agricultural Research, v. 34, n. 2, p. 109-116, 2015. http://dx.doi.org/10.22099/iar.2016.3533

KARUNARATHNE, H. D. S. S.; AMARASINGHE, B. M. W. P. K. Fixed Bed Adsorption Column Studies for the Removal of Aqueous Phenol from Activated Carbon Prepared from Sugarcane Bagasse. Energy Procedia, v. 34, p. 83-90, 2013. https://dx.doi.org/10.1016/j.egypro.2013.06.736

KASMAN, M.; IBRAHIM, S. The Removal of Iron from Landfill Leachate by Rice Husk Packed Bed Column. Journal of Chemical and Pharmaceutical Research, v. 8, n. 8, p. 1255-1262, 2016.

KAWAHIGASHI, F.; MENDES, M. B.; ASSUNÇÃO JÚNIOR, V. G. DA; GOES, V. H.; FERNANDES, F.; HIROOKA, E. Y.; KURODA, E. K. Pós-tratamento de lixiviado de aterro sanitário com carvão ativado. Engenharia Sanitária e Ambiental, v. 19, n. 3, p. 235-244, 2014. https://dx.doi.org/10.1590/S1413-41522014019000000652

LE VAN, K.; LUONG THI, T. T. Activated carbon derived from rice husk by $\mathrm{NaOH}$ activation and its application in supercapacitor. Progress in Natural Science: Materials International, v. 24, n. 3, p. 191-198, 2014. https://doi.org/10.1016/j.pnsc.2014.05.012

MOJIRI, A.; AZIZ, H. A.; ZAMANA, N. Q.; AZIZ, S. Q.; ZAHED, M. A. Powdered ZELIAC augmented sequencing batch reactors (SBR) process for co-treatment of landfill leachate and domestic wastewater. Journal of Environmental Management, v. 139, p. 1-14, 2014. https://doi.org/10.1016/j.jenvman.2014.02.017

MUNIANDY, L.; ADAM, F.; MOHAMED, A. R.; NG, E-P. The synthesis and characterization of high purity mixed microporous/mesoporous activated carbon from rice husk using chemical activation with $\mathrm{NaOH}$ and $\mathrm{KOH}$. Microporous and Mesoporous Materials, n. 197, p. 316-326, 2014. https://doi.org/10.1016/j.micromeso.2014.06.020

QUEIROZ, L. M.; AMARAL, M. S.; MORITA, D. M.; YABROUDI, S. C.; SOBRINHO, P. A. Aplicação de processos físico-químicos como alternativa de pré e pós-tratamento de lixiviados de aterros sanitários. Engenharia Sanitária e Ambiental, v. 16, n. 4, p. $403-$ 410, 2011.

TAUMA, S. L. Testes acelerados em colunas de pequena escala: o uso de carvão ativado granular em projetos de reúso de efluentes de refinarias de petróleo. 2013. 227f. Dissertação (Mestrado em Ciências) - Universidade Federal do Rio de Janeiro, Rio de Janeiro, 2013.

VIEIRA, M. G. Quitosana imobilizada em suporte inerte para a adsorção de corantes alimentícios em coluna de leito fixo. 2014. 91 f. Dissertação (Mestre em Engenharia e Ciência de Alimentos) - Universidade Federal do Rio Grande, Rio Grande, 2014. 


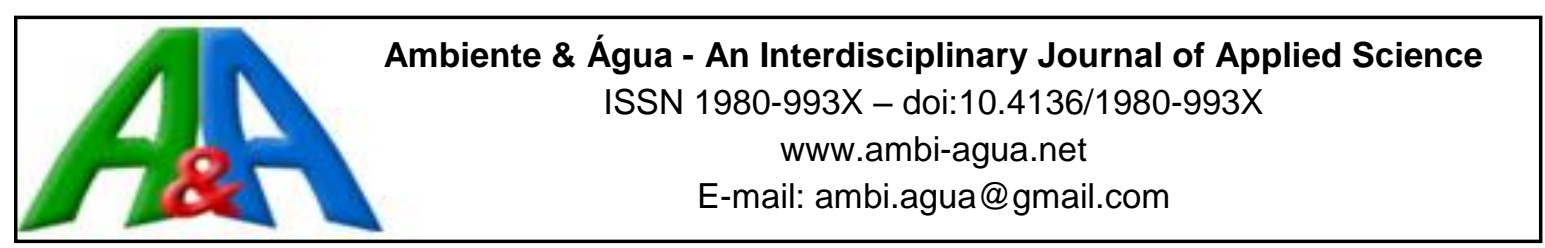

\title{
Constructed wetlands as post treatment of a decanter digester followed by an anaerobic filter
}

\author{
ARTICLES doi:10.4136/ambi-agua.2335
}

Received: 01 Oct. 2018; Accepted: 11 Jun. 2019

\author{
Wilhan Douglas Reis*iD; Aldecy de Almeida Santos ${ }^{*}$;

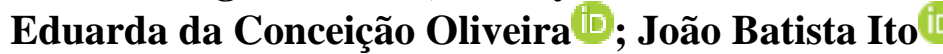 \\ Universidade Federal de Mato Grosso (UFMT), Cuiabá, MT, Brasil \\ Programa de Pós-Graduação de Recursos Hídricos (PPGRH). \\ E-mail: wilhan_cba@hotmail.com, aldecy_allmeida@yahoo.com.br, \\ eduarda.ambiental@gmail.com,jbbito2@yahoo.com.br \\ *Corresponding author
}

\begin{abstract}
The amount of wastewater has increased due to the considerable expansion of higher education institutions. When wastewater is released without treatment or with inefficient treatment, it causes significant water pollution. In this context, this study evaluated the performance of Constructed Wetlands as a post-treatment of a decanter digester followed by an anaerobic filter, operated with effluent from the Federal University of Mato Grosso, Cuiabá Campus, Mato Grosso State. Four wetlands were constructed to develop the research: planted with Typha domingensis, planted with Heliconia psittacorum, planted with Pontederia parviflora, and not planted. The following physicochemical parameters were analyzed: Color, Turbidity, pH, Temperature, Total Solids, Total Dissolved Solids (TDS), Biochemical Oxygen Demand (BOD), Chemical Oxygen Demand (COD), Total Nitrogen, Sulfate, Nitrate and Nitrite. The results show an organic matter removal efficiency with mean removal results: $70 \%$ $\mathrm{BOD}_{5}$ for $\mathrm{TCW}, \mathrm{HCW}$ and $\mathrm{PCW}$; and $\mathrm{COD} 76 \%$ for $\mathrm{PCW}$. The mean removal of total phosphorus was $78 \%$ for $\mathrm{PCW}$ and $92 \% \mathrm{NO}^{-2}$, as macronutrients. Analysis of variance ANOVA shows significance in the results of $\mathrm{TDS}, \mathrm{SO}_{4}$ and $\mathrm{COD}$ removal.
\end{abstract}

Keywords: biotechnology, horizontal subsurface flow, macrophytes, wastewater.

\section{Wetlands construídos como pós-tratamento de um decanto-digestor seguido de um filtro anaeróbio}

\section{RESUMO}

Com a crescente expansão das Instituições de Ensino Superior (IES), aumentam-se a quantidade de águas residuais, quando a mesma é lançada sem tratamento ou com tratamento ineficiente contribuem de maneira significativa para poluição dos recursos hídricos. Neste contexto, o objetivo deste trabalho foi avaliar o desempenho de Wetlands Construídos (WC) como pós-tratamento de decanto-digestor seguido de filtro anaeróbio, operados com efluente da Universidade Federal de Mato Grosso Campus Cuiabá-MT, no que se refere à remoção de nutrientes e matérias orgânicas. Para o desenvolvimento da pesquisa foram construídos quatro wetlands, sendo eles: WCT - plantado com Typha domingensis, WCH - plantado com Heliconia psittacorum, WCP plantado com Pontederia Parviflora, e WCB - não plantado. Foram 
analisados os parâmetros físico-químicos de cor, turbidez, $\mathrm{pH}$, temperatura, Sólidos Totais (ST), Sólidos Totais Dissolvidos (STD), Demanda Bioquímica de Oxigênio (DBO $)_{5}$, Demanda Química de Oxigênio (DQO), nitrogênio total, fósforo, sulfato, nitrato e nitrito. Os resultados obtidos mostram uma eficiência de remoção de matéria orgânica com resultados médios de remoção: de $\mathrm{DBO}_{5} 70 \%$ para WCT, WCH e WCP; e de DQO $76 \%$ para WCP. A remoção média de fósforo total $78 \%$ para WCP e $\mathrm{NO}^{-2} 92 \%$, como macronutrientes. A análise de variância ANOVA mostra significância nos resultados de remoção de STD, $\mathrm{SO}_{4}$ e DQO.

Palavras-chave: águas residuais, fitorremediação, fluxo horizontal subsuperficial, macrófitas.

\section{INTRODUCTION}

Wastewater from universities (WU) contains pollutant loads that, if discarded without treatment, can degrade water resources. This occurs when the pollutants are in contact with different processes of water use at universities, leading to water contamination, and thus changing chemical, physical and biological patterns (Santín et al., 2016; Freitas et al., 2016).

Wastewater treatment plants (WTPs) are responsible for restoring water quality standards to return it as naturally as possible to watercourses (Meneses et al., 2015). In order to reduce impacts caused to the environment by sanitary sewage at universities, the water goes through wastewater treatment procedures in WTPs that can efficiently remove the dissolved particles, suspended and organic loads that are added to the wastewater (Morrison et al., 2016; Wagner and Da Costa, 2015).

The Federal University of Mato Grosso is located in the Barbado Stream Basin in the city of Cuiabá, Mato Grosso state, a tributary of the Cuiabá River, and has a decanter digester as wastewater treatment, which comprises wastewater storage tanks. These tanks have active sludge inside with bacterial colonies capable of degrading organic matter through anaerobic biological processes such as hydrolysis, acidogenesis, acetogenesis, methanogenesis and sulfidogenesis. This wastewater treatment system, although simple and cheap, is inefficient in terms of organic matter removal (Chernicharo, 2019).

The aim of a Constructed Wetland $(\mathrm{CW})$ is to treat both raw and post-treatment wastewater, thus ensuring greater efficiency in the removal of organic fats and macronutrients. A CW can operate in two ways: with the flow free flow where the macrophytes are floating or emerging (Toscano et al., 2015); or with subsurface flow (Rodríguez and Brisson, 2015).

CWs are commonly used in countries such as Chile, Spain and Canada (Vera et al., 2013, Casas-Ledón et al., 2017, Caselles-Osorio et al., 2017), mainly in post-treatment, because they have plants that have the capacity to absorb macronutrients $(\mathrm{N}$ and $\mathrm{P})$, which are released in the process of decomposing matter, as well as in the nitrification process that occurs in bacteria related to the roots of plants (according to Li et al., 2015).

This study evaluated the efficiency of a $\mathrm{CW}$ as post-treatment of a decanter digester followed by an anaerobic filter on an experimental scale.

\section{MATERIAL AND METHODS}

The methodology was developed in three stages: I) designing and constructing the experiment in a pilot scale of the CW; II) monitoring the physico-chemical parameters of the WTP; and III) monitoring the physicochemical parameters and CW biomass growth.

The experiment was carried out at the WTP at the Federal University of Mato Grosso, Cuiabá Campus, located between the geographic coordinates $21 \mathrm{~S} 600022.00 \mathrm{~m} \mathrm{E}$ and $8274119.00 \mathrm{~m} \mathrm{~S}$. The climate in the city of Cuiabá is characterized as continental tropical, with two distinct seasonal seasons, one rainy (October-March) and the other dry (April-September). It has an annual precipitation of $1.262 \mathrm{~mm}$ and an average temperature of $25,91^{\circ} \mathrm{C}$ (INMET, 2018).

Rev. Ambient. Água vol. 14 n. 4, e2335 - Taubaté 2019 
The wastewater treatment system is formed by a lift station that receives the WU, from the sanitary station of the university, and from the Jardim América neighborhood. It is then pumped to the WTP, which is comprised of a Decanter Digestor, where the degradation of organic matter occurs anaerobically. This is followed by a biofilter, which retains part of the dissolved solids of the system, and then finally the Drying Bed (DB).

The treated effluent from the WTP was moved by a peristaltic pump to a reservoir of $1 \mathrm{~m}^{3}$ made of polyethylene, then by gravity to $\mathrm{CWs}$, which were fed continuously in a subsurface form with controlled flows in each $\mathrm{CW}$, at a flow rate of 50 liters / 10 days. The internal volume of the tanks used in the $\mathrm{CW}$ implantation was $0.45 \mathrm{~m}^{3}$, made of high-density polyethylene, with a surface length of $2.20 \mathrm{~m}$ and a depth of $1.84 \mathrm{~m}$, a surface width of $0.71 \mathrm{~m}$, and a bottom measuring $0.33 \mathrm{~m}$, respectively. The substrate filling consisted of a sequence of filter layers: hand stone, washed sand and gravel $\mathrm{N}^{\circ} .02$.

Four wetlands were constructed, with three different species of macrophytes in separate planted CWs and one unplanted CW; those that were planted had a density of 10 rhizomes per CW, divided into the following: one was planted with Typha domingensis (TCW), one planted with Heliconia psittacorum (HCW), one planted with Pontederia Parviflora (PCW), and one was not planted (NCW) in order to obtain the block of the treatment tanks (Figure 1).
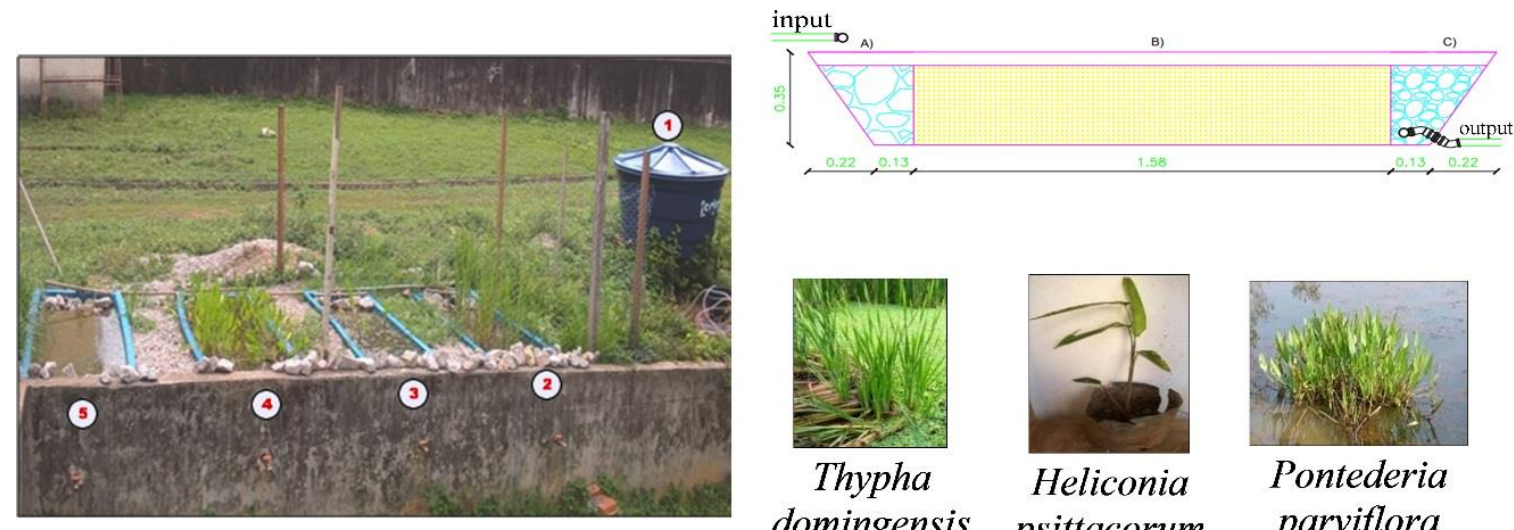

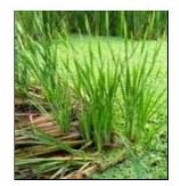

Thypha

domingensis

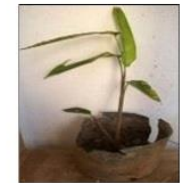

Heliconia

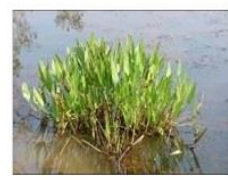

Pontederia parviflora

1Reservoir; $2 \mathrm{CW}$ planted with Thypha; $3 \mathrm{CW}$ planted with Heliconia; $4 \mathrm{CW}$ with Pontederia; and $5 \mathrm{CW}$ not planted. A) stone hand; $\mathrm{B}$ ) sand; C) gravel $\mathrm{N}^{\circ} 2$

Figure 1. Constructed Wetland.

Sampling was carried out from October 2017 to February 2018, and six points were monitored at the WTP: Gross Effluent - Point 1 (P1) - Landfill and Treated Effluent - Point 2 (P2) - Biofilter Output, considering the flow of the system structure. The other four samples at the output of each CW, occurring over a period of 150 days, complied with the Hydraulic Detention Time (HDT) of 5 and 10 days. The samples were collected using collector tubes installed in each CW tank at the following sampling points: TCW, HCW, PCW and NCW.

Samples were analyzed considering the following parameters: Total Dissolved Solids TDS (mg /l), Total Phosphorus - TP (mg/l), Sulphate - $\mathrm{SO}_{4}(\mathrm{mg} / \mathrm{l})$, Nitrate $-\mathrm{NO}^{-3}(\mathrm{mg} / \mathrm{l})$, Nitrite - $\mathrm{NO}^{-2}(\mathrm{mg} / \mathrm{l})$, Total Nitrogen - TN (mg/l), pH, Biochemical Oxygen Demand - BOD 5 (mg/l) and Chemical Oxygen Demand - COD (mg/l).

After collecting the concentration results of the TDS, TP, $\mathrm{SO}_{4}, \mathrm{NO}^{-3}, \mathrm{NT}, \mathrm{NO}^{-2}, \mathrm{BOD}_{5}$ and COD parameters, they were submitted to Equation 1 to each $\mathrm{CW}$ to obtain the Removal Efficiency.

$$
R E=\frac{\operatorname{Conc}(P 2)-\operatorname{Conc}(C W)}{\operatorname{Conc}(P 2)} \times 100
$$

At where:

$\underline{\text { Conc }(\mathrm{CW}) \neq 0}$ 


\subsection{Biomass}

Every 10 days, four plants from each treatment were collected and separated into roots, leaves and stems. Afterwards, the roots were washed in running water and distilled to remove soil. The vegetal material was placed individually in paper bags, properly identified and then dried in a forced ventilation oven at $70^{\circ} \mathrm{C}$ for 48 hours. Finally, the material was weighed to calculate the dry mass of the leaves, roots and stems of each plant.

Statistical analyses of the results from the laboratory analyses were performed by the paired ANOVA test that evaluated the variance of the results, as well as the standard deviation between them. Significant differences in water quality between wet and dry plant species were evaluated using a completely randomized analysis of variance with significance of 5\% and $10 \%$. To prove the variance test, the correlation test was used to determine the relationship between the parameters.

\section{RESULTS AND DISCUSSION}

Dissolved Oxygen inside the WTP and CW varied between 0.91 and 7.24; the WTP output was lower than the standards established by CONAMA (Brazilian National Council for the Environment) due to the anaerobic system where the $\mathrm{pH}$ rises and DO decreases (Figure 2). The CWs had a higher oxygen insertion at the beginning of the experiment, decreasing after the month of January. This variation is related to plant respiration and biofilm development using DO in the decomposition of organic matter (Pelissari et al., 2014).

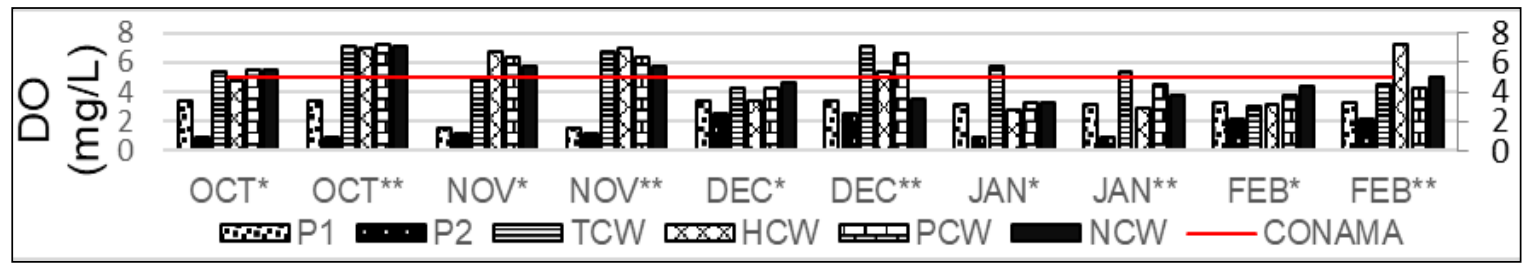

Figure 2. Dissolved Oxygen Variation.

The results of $\mathrm{pH}$ and $\mathrm{CW}$ in the WTP varied between 8.95 and 6.81, within the range established by CONAMA (Figure 3), and the most alkaline result was recorded in the HCW in the HDT on October 10th, and the most acidic result was recorded in the TCW in the HDT also on October $10^{\text {th }}$. These values correspond to those of Caselles-Osorio (2017), who states that plant root growth can influence plant $\mathrm{pH}$ by acidifying the medium with carbon production due to respiration (Kadlec et al., 1996; Vymazal, 2007).

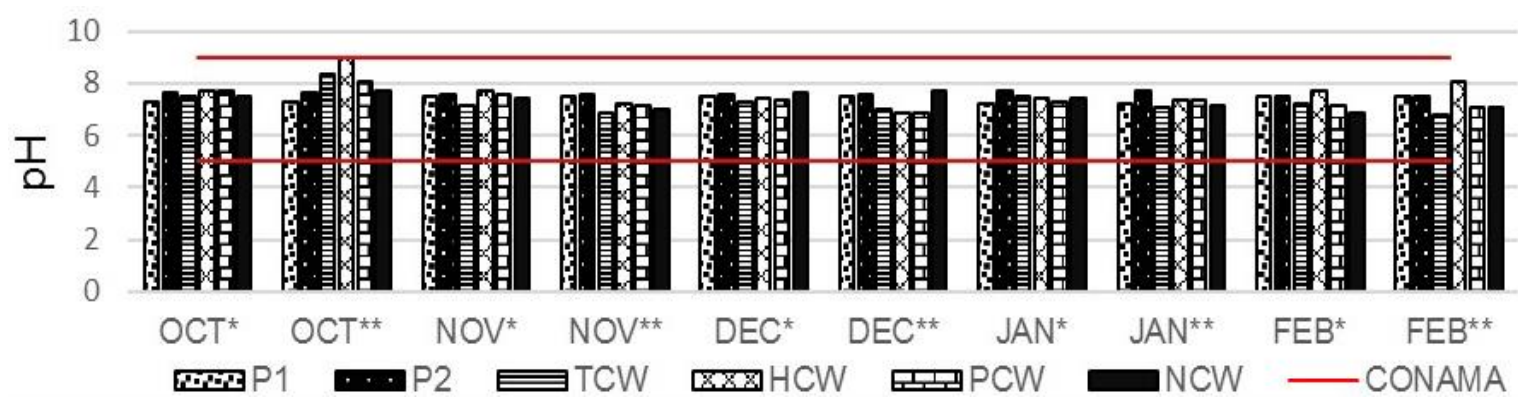

Figure 3. $\mathrm{pH}$ variation.

The CW removals were calculated in relation to $\mathrm{P} 1$ following the research sample; therefore, the average removal efficiency of the TDS in the HDT of 5 days was highlighted by the PCW, with 51\%. The others had close values, which were $48 \%, 50 \%$ and $46 \%$ for TCW, $\mathrm{HCW}$ and NCW, respectively. In the 10-day results, the efficiencies of all CWs rose. The PCW

Rev. Ambient. Água vol. 14 n. 4, e2335 - Taubaté 2019 
had the best result, with a value of $73 \%$, while the other TCW, HCW, NCW obtained $71 \%$, $72 \%$ and $61 \%$, respectively. These values show that there was increased efficiency in the TDS, similar to those of Sehar et al., who obtained efficiency values between $42 \%$ and $74 \%$, in their experiment at a 20-day TDH. In the present study, it was observed that the removal of TS is related to sorption in the filter medium, absorption by the plants (Figure 4) (Sezerino et al., 2015).
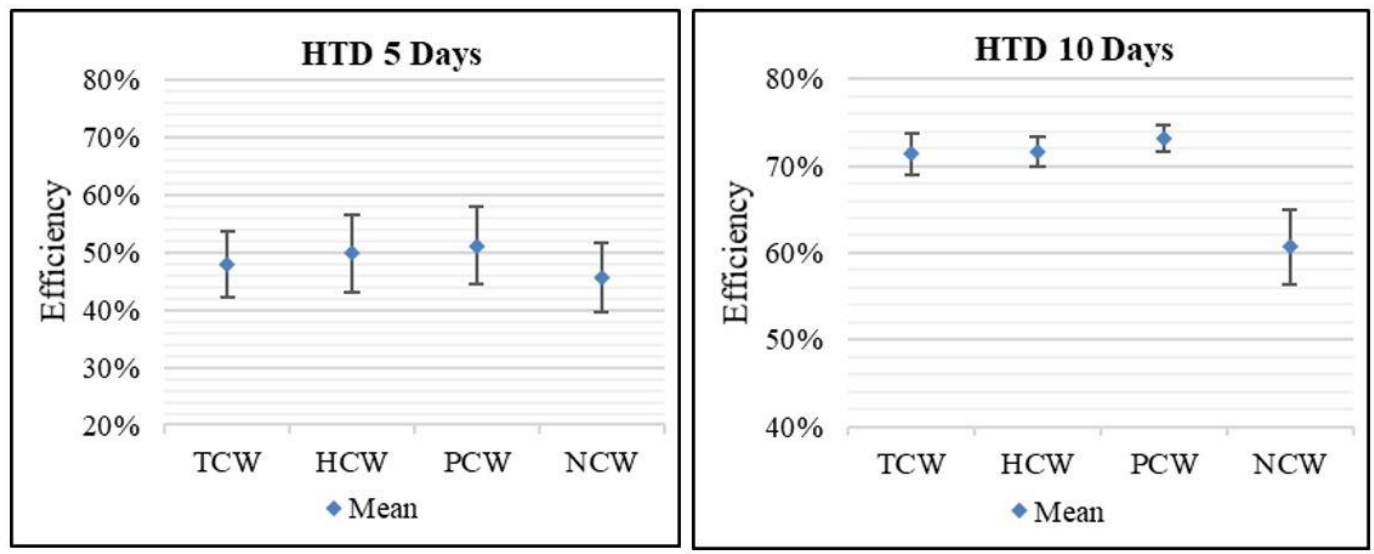

Figure 4. Total Dissolved Solids efficiency.

Phosphorus in the CW had a great variation mainly in the months of November 2017 and February 2017, but the CW behaved efficiently in both concentrations. The average phosphorus efficiencies in the HDT of 10 days were $49 \%, 45 \%, 78 \%$ and $41 \%$, for TCW, HCW, PCWP and NCW, respectively.

The $\mathrm{P}$ is part of the macronutrients that the plants absorb to use in their metabolic compositions, comparing the phosphorus concentrations with Abou-Elela and Hellal (2012) and Leto et al. (2013) who obtained a result of $62 \%$ removal and $47.9 \%$ with a concentration of $0.4 \mathrm{mg} / \mathrm{l}$ and $4.2 \mathrm{mg} / \mathrm{l}$. The PCW obtained better removal results, while TCW, HCW and NCW obtained results of efficiency lower than both (Figure 5).

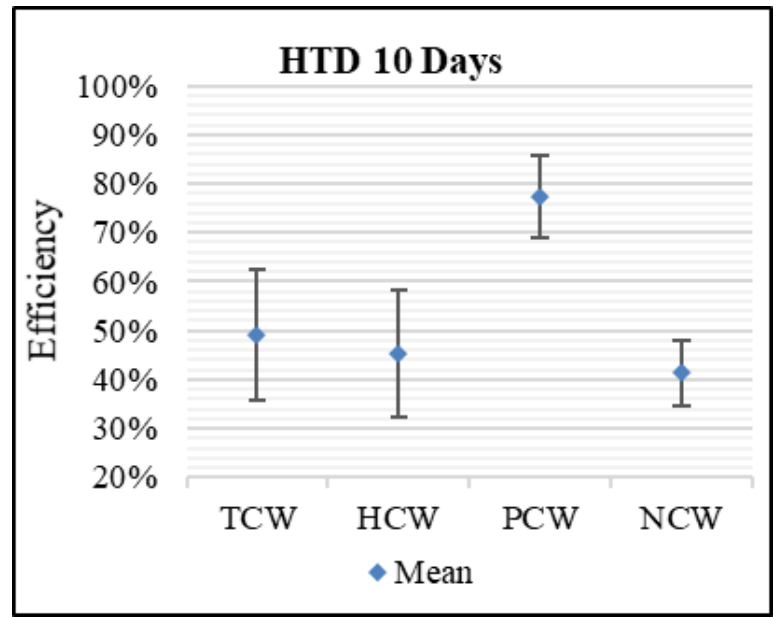

Figure 5. Phosphorus efficiency.

The mean sulphate efficiencies in 5 days of HDT were $60 \%, 59 \%, 65 \%$ and $35 \%$ for TCW, HCW, PCW and NCW, respectively; and in 10 days of HDT were 95\%, 99\%, 95\% and 93\% for TCW, HCW, PCW and NCW, respectively. These results show that in the planted CWs, there was higher sulphate removal efficiency compared to the non-planted ones. This may be related to oxygen in the available plant roots (Figure 6).

\section{IPABH}

Rev. Ambient. Água vol. 14 n. 4, e2335 - Taubaté 2019 

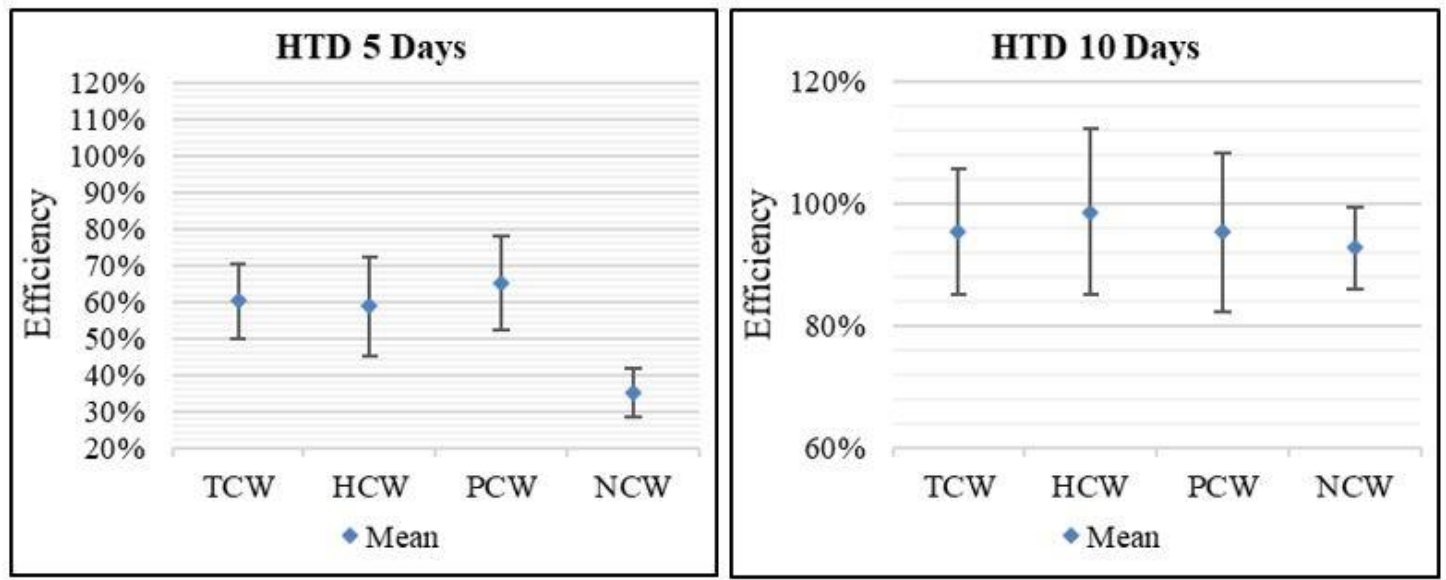

Figure 6. Sulphate efficiency.

The mean efficiency of $\mathrm{NO}^{-2}$ in the HDT of 5 days was: $68 \%, 57 \%, 61 \%$ and $66 \%$ for TCW, HCW, PCW and NCW, respectively; for 10 days, it was $92 \%, 88 \%, 89 \%$ and $78 \%$, for TCW, HCW, PCW and NCW, respectively. The mean $\mathrm{NO}^{-3}$ removal in the HDT of 5 days was $66 \%, 66 \%, 67 \%$ and $57 \%$ for TCW, HCW, PCW and NCW, respectively; for 10 days it was $86 \%, 75 \%, 82 \%$ and 67 for TCW, HCW, PCW and NCW, respectively. The removal of $\mathrm{NO}^{-3}$ and $\mathrm{NO}^{-2}$ occurs due to the absorption of nutrients by plants and the release of oxygen forming $\mathrm{N}_{2}$ (Sehar et al., 2014). Maine et al. (2006) obtained results of $88 \%$ and $85 \%$ concerning the removal of $\mathrm{NO}^{-3}$ and $\mathrm{NO}^{-2}$, in WC planted with Typha domingensis and Panicum elephantipes (Figure 7).

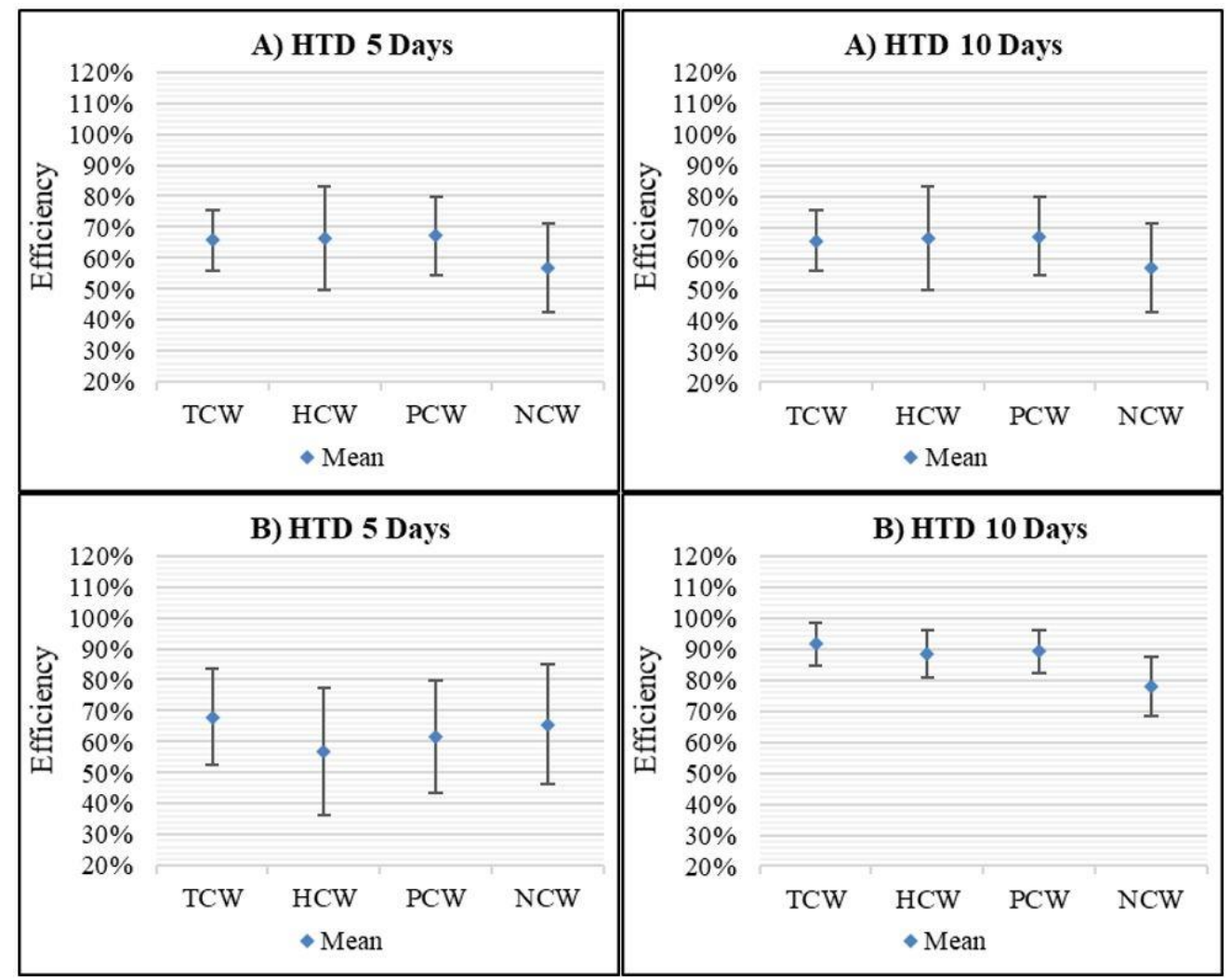

Figure 7. Efficiency of Nitrite and Nitrate.

The mean total nitrogen efficiency results in the HDT of 10 days were $52 \%, 42 \%, 34 \%$ and $31 \%$, for TCW, HCW, PCW and NCW, respectively. The maximum removal in the PCW 
was the one that stood out, as it had $60 \%$ in October 2017. Hsu et al. (2011) obtained a result of Total Nitrogen removal in a natural wetland which is close to the results of the present study. However, in an experiment similar to this one, Rodríguez and Brisson (2015) managed a removal of $97 \%$ (Figure 8 ).

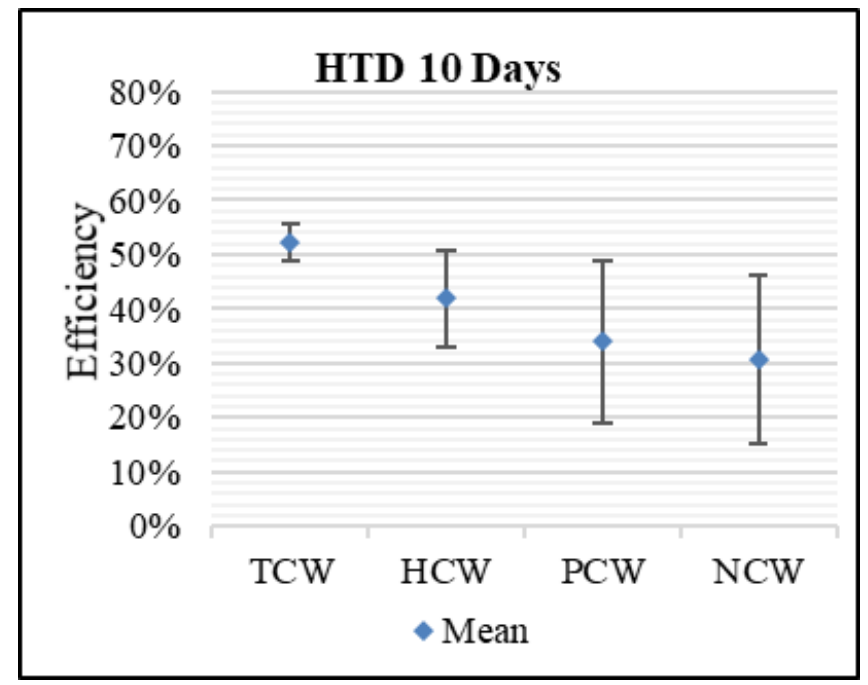

Figure 8. Total Nitrogen Removal.

The BOD 5 obtained the mean efficiency for the HDT of 5 days, which was less than $50 \%$. The CW that had the best mean efficiency was HCW with $45 \%$, then PCW with $44 \%$, TCW with $42 \%$ and NCW with $38 \%$. However, the results of the 10-day analysis were the same for all planted CWs at 70\%, and the NCW was 66\%. The 5-day and 10-day HDT efficiency values, despite being effective in maintaining lower load effluent within the limits of CONAMA 357/05, these same results in the HDT of 5 days are lower than those of Sohsalam et al. (2008); Vera et al. (2013) and Abou-Elela and Hellal (2012); and the efficiency result in the HDT of 10 days are equal to these authors. $\mathrm{BOD}_{5}$ removal occurs due to deposition and filtration, while organic compounds were degraded aerobically and anaerobically by heterotrophic microorganisms, depending on the concentration of oxygen in the bed (Figure 9).
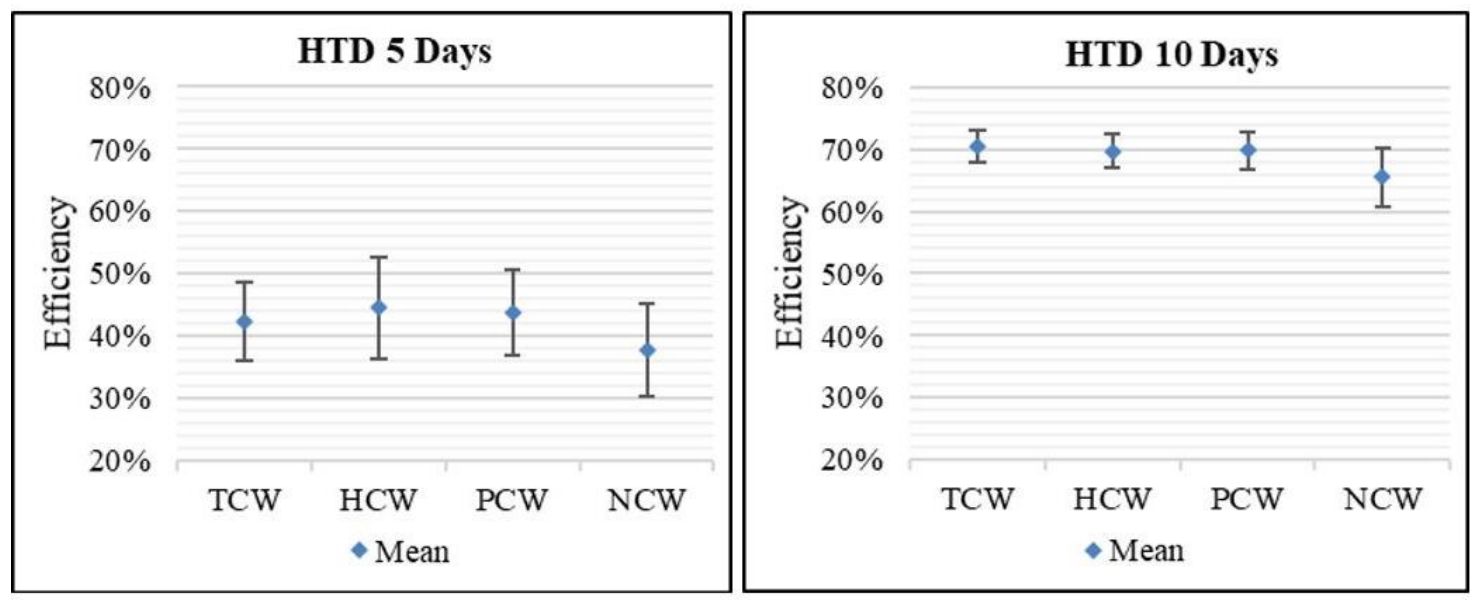

Figure 9. $\mathrm{BOD}_{5}$ efficiency.

The mean COD removals for TCW, HCW, PCW and NCW were $42 \%, 34 \%, 47 \%$ and $29 \%$, respectively, in the HDT of 5 days. In the HDT of 10 days, the values were close, ranging from $76 \%$ to $69 \%$. The COD values were similar to those of Ansola et al. (2003), Caselles-Osorio et al. (2011) and Ebrahimi et al. (2013), who had mean values of efficiency of 79\%, 75\% and 
$72 \%$. These studies found a greater efficiency in planted CWs due to the assimilation of the plant to organic materials and macro nutrients found in the wastewater (Figure 10).
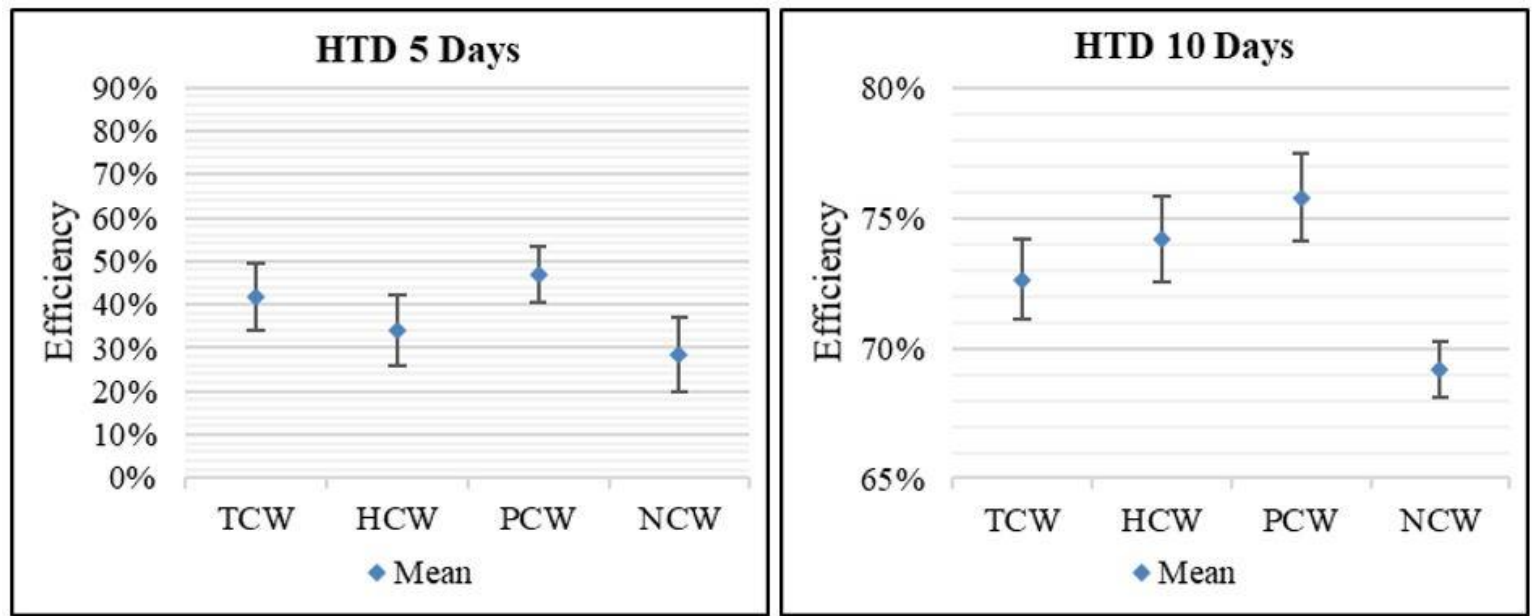

Figure 10. COD efficiency.

\subsection{Development of macrophytes}

The macrophytes were planted in their young stage and accompanied by their growth in height $(\mathrm{cm})$ and weight $(\mathrm{g})$. The result shows the growth variation between plants from the young to the adult stages. Among the macrophytes, Typha domingensis and Pontederia parviflora evolved in the analyzed period; however, Heliconia psittacorum had a low adaptation to the wetland system implanted (Figure 11).
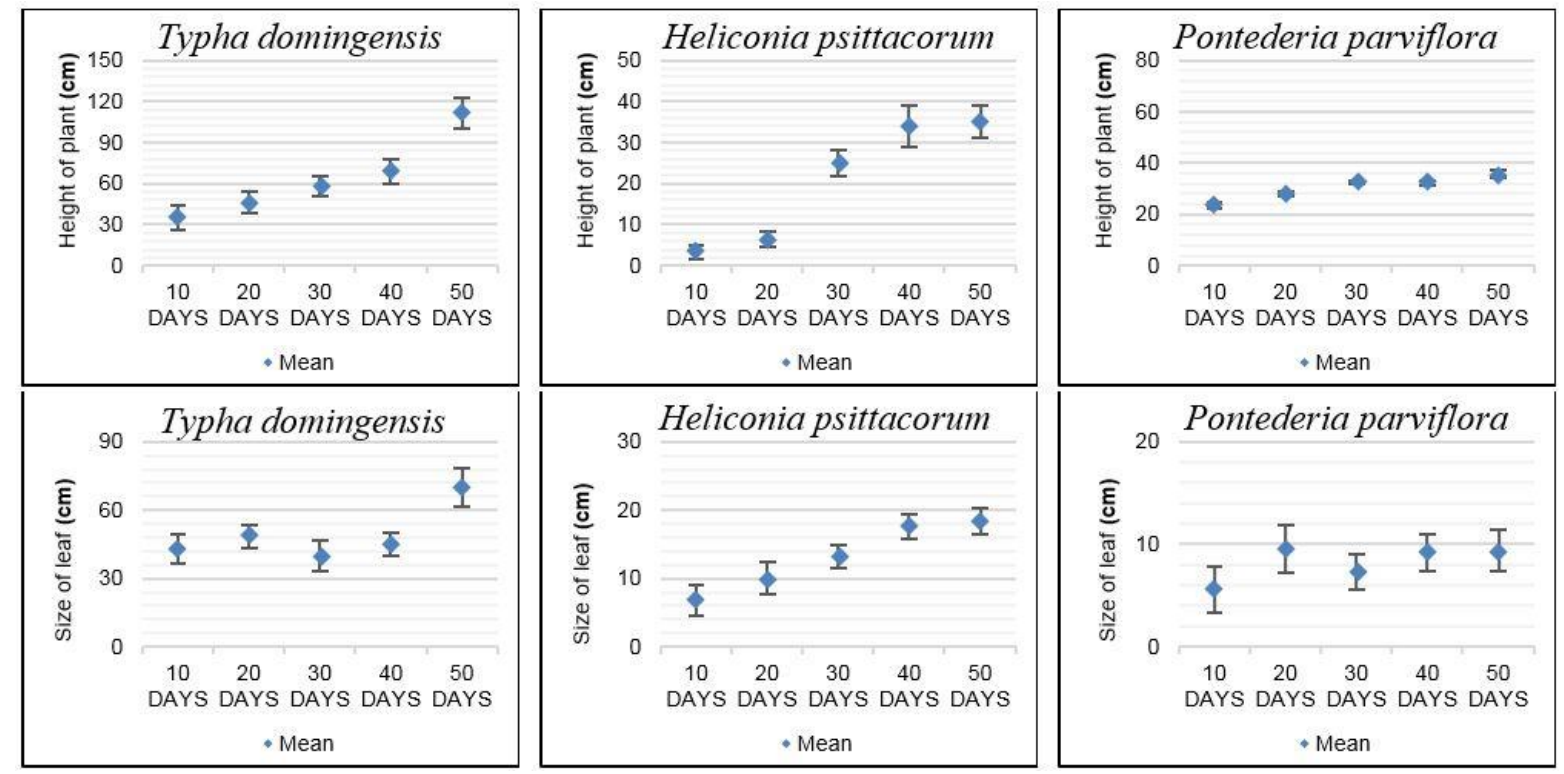

Figure 11. Total Nitrogen Removal.

The average height of the Typha domingensis plant in October 2017 was $35.2 \mathrm{~cm}$, and in February 2018 it had an average size of $111.2 \mathrm{~cm}$. In addition, Heliconia psittacorum obtained an average height in October 2017 of $3.36 \mathrm{~cm}$, and in February 2018 it was $35.2 \mathrm{~cm}$. The Pontederia parviflora species reached $23.55 \mathrm{~cm}$ at the beginning of the period, and at the end $35.6 \mathrm{~cm}$ (Figure 12). 


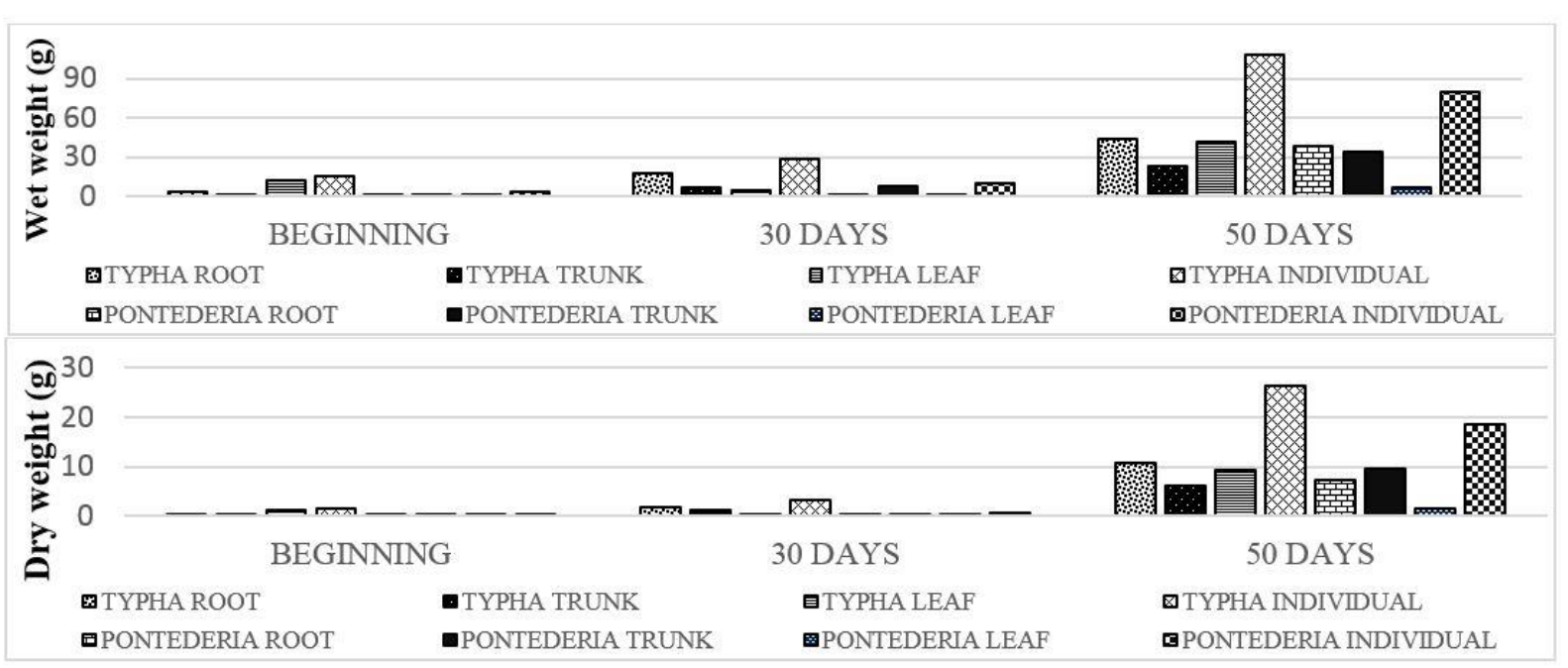

Figure 12. Macrophyte growth.

The mean growth of the leaf of the Typha domingensis species was initially $43.05 \mathrm{~cm}$, reaching $72.02 \mathrm{~cm}$; compared to Lorenzen et al. (2001), Typha domingensis had similar growth, and in its experiment the final size was $97 \mathrm{~cm}$. On the other hand, the species Heliconia psittacorum had an average increase of $6.74 \mathrm{~cm}$, and at the end of the studied period reached $18.40 \mathrm{~cm}$, compared to Cerqueira et al. (2008). These species showed considerable development, since species presented average growth of $97.1 \mathrm{~cm}$. The average leaf length of the Pontederia parviflora started at 5.70 and ended at $9.45 \mathrm{~cm}$. The biomass growth was measured in the Typha domingensis and Pontederia parviflora species, comparing the beginning and end period of 50 days. In the first plant there was an individual increase in its wet weight of $92.53 \mathrm{~g}$ and in the dry weight of $24.60 \mathrm{~g}$, compared to the second. Regarding the Pontederia parviflora species, the individual wet weight was $76.36 \mathrm{~g}$ and the dry weight was $18.15 \mathrm{~g}$. In this plant biomass analysis, we were not able to determine the weight of the Heliconia psittacorum.

\subsection{Statistical Analysis}

The static ANOVA test was performed for 5 and 10 days of HDT, with a significance of $5 \%$ for all parameters. The COD, $\mathrm{SO}_{4}$ and TDS, both for 10 days of HDT, were significant at $10 \%$, according to ANOVA.

\section{CONCLUSION}

To sum up the experiment, it was concluded that the wetlands present a greater concentration removal in the CWs (TCW, HCW and PCW) than in the non-planted ones. Among those planted, PCW was the one that most stood out in the removal of organic matter and macronutrients. It was the $\mathrm{CW}$ that obtained the highest result in 7 of the analyzed parameters in the HDTs of 5 days and 10 days.

Plant growth was fast, as the Typha domingensis and Pontederia parviflora species flowered at the end of five months, and also multiplied in individuals. However, Heliconia psittacorum showed a slower evolution with little productive adaptation.

The parameters such as $\mathrm{COD}, \mathrm{SO}_{4}$ and TDS had a significance of 5\% in the ANOVA test, proving that HDT in the $\mathrm{CW}$ can be efficient in the removal of these pollutants even with the variation of the input load.

\section{IPABH}

Rev. Ambient. Água vol. 14 n. 4, e2335 - Taubaté 2019 


\section{REFERENCES}

ABOU-ELELA, S. I.; HELLAL, M. S. Municipal wastewater treatment using vertical flow constructed wetlands planted with Canna, Phragmites and Cyprus. Ecological Engineering, v. 47, p. 209-213, 2012. https://doi.org/10.1016/j.ecoleng.2012.06.044

ANSOLA, G. et al. Experimental and full-scale pilot plant constructed wetlands for municipal wastewaters treatment. Ecological Engineering, v. 21, p. 43-52, 2003. https://doi.org/10.1016/j.ecoleng.2003.08.002

CASAS-LEDÓN, Y. et al. Life-cycle greenhouse gas emissions assessment and extended exergy accounting of a horizontal-flow constructed wetland for municipal wastewater treatment: A Case Study in Chile. Ecological Indicators, v. 74, p. 130-139, 2017. https://doi.org/10.1016/j.ecolind.2016.11.014

CASELLES-OSORIO, A. et al. Efficiency of Mesocosm-Scale Constructed Wetland Systems for Treatment of Sanitary Wastewater Under Tropical Conditions. Water Air Soil Pollut, v. 220, p. 161-171, 2011. https://doi.org/10.1007/s11270-011-0743-7

CASELLES-OSORIO, A. et al. Horizontal subsurface-flow constructed wetland removal efficiency using Cyperusarticulatus L. Ecological Engineering, v. 99, p. 479-485, 2017. https://doi.org/10.1016/j.ecoleng.2016.11.062

CERQUEIRA, L. L. et al. Desenvolvimento de Heliconia psittacorum e Gladiolus hortulanus irrigados com águas residuais tratadas. Revista Brasileira de Engenharia Agrícola e Ambiental, p. 606-613, 2008.

CHERNICHARO, C. A. D. L. Reator anaeróbios. 2. ed. Belo Horizonte: Editora UFMG, 2019.

EBRAHIMI, A. et al. Efficiency of Constructed Wetland Vegetated with Cyperus alternifolius Applied for Municipal Wastewater Treatment. Hindawi Publishing Corporation Journal of Environmental and Public Health, v. 2013, 2013. http://dx.doi.org/10.1155/2013/815962

FREITAS, G. P. D. et al. Sistema de tratamento de efluentes para o campus da Universidade Federal de Campina Grande na cidade de Pombal. Revista Verde de Agroecologia e Desenvolvimento Sustentável, v. 11, n. 2, p. 08-12, 2016.

HSU, C.-B. et al. Biodiversity of constructed wetlands for wastewater treatment. Ecological Engineering, v. 37, p. 1533-1545, 2011. https://doi.org/10.1016/j.ecoleng.2011.06.002

INMET. Banco de Dados Meteorológicos para Ensino e Pesquisa. 2018. Available at: http://www.inmet.gov.br/sonabra/pg_dspDadosCodigo_sim.php?QTkwMQ==. Access: 9 Mar. 2018.

KADLEC, R. H.; KNIGHT, R. L. Treatment Wetlands. Boca Raton: Lewis Publishes, 1996.

LETO, C. et al. Effects of plant species in a horizontal subsurface flow constructed wetland phytoremediation of treated urban wastewater with Cyperus alternifolius L. and Typha latifolia L. in the West of Sicily (Italy). Ecological Engineering, v. 61, p. 282-291, 2013. https://doi.org/10.1016/j.ecoleng.2013.09.014 
LI, X. et al. The Significance of Myriophyllum elatinoides for Swine Wastewater Treatment: Abundance and Community Structure of ammonia - Oxidizing Microorganisms in Sediments. Plos One, v. 10, n. 10, 2015. https://doi.org/10.1371/journal.pone.0139778

LORENZEN, B. et al. Growth, biomass allocation and nutrient use efficiency in Cladium Jamaicense and Typha domingensis as affected by phosphorus and oxygen availability. Aquatic Botany- Elsevier, v. 70, p. 117-133, 2001. https://doi.org/10.1016/S03043770(01)00155-3

MAINE, M. A. et al. Nutrient and metal removal in a constructed wetland for wastewater treatment from a metallurgic industry. Ecological Engineering, v. 26, p. 341-347, 2006. https://doi.org/10.1016/j.ecoleng.2005.12.004

MENESES, M. et al. Life Cycle Assessment as an environmental evaluation tool for control strategies in wastewater treatment plants. Journal of Cleaner Production, v. 107, n. 65, p. 653-661, 2015. https://doi.org/10.1016/j.jclepro.2015.05.057

MORRISON, M.; SRINIVASAN, R. S.; RIES, R. Complimentary life cycle assessment of wastewater treatment plants: An integrated approach to comprehensive upstream and downstream impact assessments and its extension to building-level wastewater generation. Sustainable Cities and Society, v. 23, p. 37-49, 2016. https://doi.org/10.1016/j.scs.2016.02.013

PELISSARI, C. et al. Nitrogen transformation in horizontal and vertical flow constructed wetlands applied for dairy cattle wastewater treatment in southern Brazil. Ecological Engineering, v. 73, p. 307-310, 2014. https://doi.org/10.1016/j.ecoleng.2014.09.085

RODRÍGUEZ, M.; BRISSON, J. Pollutant removal efficiency of native versus exotic common reed (Phragmitesaustralis) in North American treatment wetlands. Ecological Engineering, v. 74, p. 364-370, 2015. https://doi.org/10.1016/j.ecoleng.2014.11.005

SANTÍN, I. et al. Advanced decision control system for effluent violations removal in wastewater treatment plants. Control Engineering Practice, v. 49, p. 60-75, 2016. https://doi.org/10.1016/j.conengprac.2016.01.005

SEHAR, S. et al. A comparative study of macrophytes influence on wastewater treatment through subsurface flow hybrid constructed wetland. Ecological Engineering, v. 1, p. 62-69, 2014. https://doi.org/10.1016/j.ecoleng.2015.04.009

SEZERINO, P. H. et al. Experiências brasileiras com wetlands construídos aplicados ao tratamento de águas residuárias: parâmetros de projeto para sistemas horizontais. Engenharia Sanitária Ambiental, v. 20, n. 1, p. 151-158, 2015. https://dx.doi.org/10.1590/S1413-41522015020000096615

SOHSALAM, P.; ENGLANDE, A. J.; SIRIANUNTAPIBOON, S. Seafood wastewater treatment in constructed wetland: Tropical case. Bioresource Technology, v. 99, p. 12181224, 2008. https://doi.org/10.1016/j.biortech.2007.02.014

TOSCANO, A. et al. Comparison of removal efficiencies in Mediterranean pilot constructed wetlands vegetated with different plant species. Ecological Engineering, v. 75, p. 155160, 2015. https://doi.org/10.1016/j.ecoleng.2014.12.005

VERA, L.; MARTEL, G.; MÁRQUEZ, M. Two years monitoring of the natural system for wastewater reclamation in Santa Lucía, Gran Canaria Island. Ecological Engineering, v. 50, p. 21-30, 2013. https://doi.org/10.1016/j.ecoleng.2012.08.001 
VYMAZAL, J. Removal of nutrients in various types of constructed wetlands. Science of the $\begin{array}{llllll}\text { Total Environment, } & \text { v. } 380, & \text { p. } & 48-65, & \end{array}$ https://doi.org/10.1016/j.scitotenv.2006.09.014

WAGNER, J.; DA COSTA, R. H. R. Reator em bateladas sequenciais de grânulos aeróbios: estudo da formação dos grânulos e do efeito da duração do ciclo na remoção de carbono, nitrogênio e fósforo de esgoto doméstico. Engenharia Sanitária Ambiental, v. 20, n. 2, p. 269-278, 2015. https://dx.doi.org/10.1590/S1413-41522015020000078980 